UNIVERSIDADE DE BRASÍLIA - UnB

Instituto de Relações Internacionais - IREL

Área de Concentração: Política Internacional e Comparada (Segurança

Internacional e Democracia)

THAÍS DE OLIVEIRA QUEIROZ

Tese de Doutorado

\begin{abstract}
TRAJETÓRIAS DEMOCRÁTICAS E ESTRATÉGIAS DE LIBERALIZAÇÃO POLÍTICA: A EVOLUÇÃO DA DEMOCRACIA NOS PAÍSES AFRICANOS DE LÍNGUA OFICIAL PORTUGUESA NO PÓS-GUERRA FRIA
\end{abstract}

Orientador: Prof. Dr. Pio Penna Filho

Brasília 
UNIVERSIDADE DE BRASÍLIA - UnB

Instituto de Relações Internacionais - IREL

\title{
TRAJETÓRIAS DEMOCRÁTICAS E ESTRATÉGIAS DE LIBERALIZAÇÃO POLÍTICA: A EVOLUÇÃO DA DEMOCRACIA NOS PAÍSES AFRICANOS DE LÍNGUA PORTUGUESA NO PÓS-GUERRA FRIA
}

\author{
Thaís de Oliveira Queiroz
}

Tese de Doutorado submetida ao Instituto de Relações Internacionais da Universidade de Brasília como parte dos requisitos necessários para a obtenção do Grau de Doutora em Relações Internacionais, área de concentração em Política Internacional e Comparada.

Banca Examinadora:

Dr. Pio Penna Filho (IREL/UnB) - Orientador

Dr. Fábio Albergaria de Queiroz (Universidade Católica de Brasília) - Membro Externo

Dra. Maria Helena de Castro Santos (IREL/UnB) - Examinadora Interna

Dr. José Flávio Sombra Saraiva (IREL/UnB) - Examinador Interno

Dr. Aninho Mucundramo Irachande (IPOL/UnB) - Examinador Externo

Dr. Juliano da Silva Cortinhas (IREL/UnB) - Suplente 
QUEIROZ, Thaís de Oliveira.

Trajetórias Democráticas e Estratégias de Liberalização: a Evolução da Democracia nos Países Africanos de Língua Oficial Portuguesa no PósGuerra Fria. XXX p. (UnB/IREL, Política Internacional e Comparada, 2017). Tese de Doutorado - Universidade de Brasília. Instituto de Relações Internacionais.

I. UnB - IREL II. Título (série)

É concedida à Universidade de Brasília permissão para reproduzir cópias desta tese e emprestar ou vender tais cópias somente para propósitos acadêmicos e científicos. A autora reserva outros direitos de publicação e nenhuma parte desta tese de doutorado pode ser reproduzida sem a autorização por escrito da autora. 
There is something in the soul that cries out for freedom.

Martin Luther King Jr.

Ó mar salgado, quanto do teu sal

São lágrimas de Portugal!

Por te cruzarmos, quantas mães choraram,

Quantos filhos em vão rezaram!

Quantas noivas ficaram por casar

Para que fosses nosso, ó mar!

Valeu a pena? Tudo vale a pena

Se a alma não é pequena.

Quem quer passar além do Bojador

Tem que passar além da dor.

Deus ao mar o perigo e o abismo deu,

Mas nele é que espelhou o céu.

Fernando Pessoa 


\section{AGRADECIMENTOS}

Primeiramente agradeço a Deus pela oportunidade de ter concluído este estudo doutoral. Agradeço a espiritualidade amiga pela força e inspiração diárias que me fizeram prosseguir com esse projeto durante quatro anos.

Agradeço a minha família, principalmente o meu pai, minha mãe, meu noivo, meu irmão e meus avós, bem como os meus amigos pelo apoio constante, pelas palavras de incentivo e por acreditarem no meu potencial, mesmo nos momentos mais difíceis dessa trajetória acadêmica. Agradeço também o amigo Gustavo, que me ajudou imensamente no período de coleta de dados.

Agradeço o meu orientador, o professor Pio Penna, pelo auxílio, compreensão e por me apresentar o fascinante mundo da África.

Agradeço a minha co-orientadora, a professora Edalina Sanches, que me recebeu com muito carinho durante o período que estive em Portugal como pesquisadora visitante no Instituto de Ciências Sociais (ICS) da Universidade de Lisboa, me mostrando uma nova perspectiva sobre a democracia nos PALOP. Agradeço também a todos os colegas, professores e amigos que me ajudaram durante esse período de intercâmbio, em especial àqueles do Centro de Estudos Africanos do ISCTE - Instituto Universitário de Lisboa.

Agradeço a professora Maria Helena de Castro Santos por ter me ensinado praticamente tudo o que sei sobre Política Comparada, me orientando durante as minhas graduações e Mestrado na UnB.

Agradeço os professores do Instituto de Relações Internacionais da UnB (IREL), que me ensinaram e apresentaram o universo das relações internacionais durante os mais de dez anos que estive como aluna na universidade.

Agradeço a Secretaria de Relações Internacionais do IREL, principalmente o Anderson, Odalva e Wanderlei, que sempre me ajudaram com um sorriso e palavra amiga.

Por fim, agradeço a Universidade de Brasília, que me permitiu realizar muitos sonhos desde 2006, quando ingressei no curso de graduação em Relações Internacionais. 
Agradeço a instituição pelo aprendizado, pelos amigos, pelas experiências inesquecíveis e pelo conhecimento específico que obtive para a minha formação profissional. Fico imensamente feliz por ter trilhado a minha vida acadêmica até o doutorado nesse espaço único de liberdade e de pluralidade de saberes. 


\section{RESUMO}

O colapso soviético marcou um momento histórico único no mundo. Entre as suas inúmeras consequências, pode-se citar a liberalização política de grande parte do continente africano, que ocorreu devido às pressões externas advindas das grandes potências Ocidentais. Imerso nesse cenário, encontra-se o singular conjunto dos Países Africanos de Língua Oficial Portuguesa (PALOP), que apresentou no seu escopo transições democráticas que seguiram trajetórias próprias nos últimos 25 anos. Nesse contexto, a presente tese teve como objetivo analisar as democratizações dos PALOP no pós-Guerra Fria, visando a compreender o sucesso da democracia nos PALOP insulares (Cabo Verde e São Tomé e Príncipe) e o seu relativo insucesso nos PALOP continentais (Moçambique, Guiné-Bissau e Angola). Para a realização desse trabalho, foi utilizada uma metodologia comparada, na qual os principais aspectos das democratizações desses países foram analisados de maneira longitudinal, verificando os seus padrões de similaridades e diferenças por meio de três estudos de caso. Cada caso abarcou um período histórico distinto, a saber: domínio colonial português, regime de partido único e democratização após 1990. Destarte, a hipótese comprovada pautou-se no fato de que o sucesso democrático dos PALOP insulares se explicou devido à sua estabilidade social, política e econômica durante o seu processo de liberalização e transição para a democracia. Da mesma forma, o relativo insucesso democrático dos PALOP continentais ocorreu devido a sua instabilidade social, política e econômica nesse mesmo período. No referido cenário, as principais variáveis que influenciaram esse resultado relacionam-se ao fato de que Cabo Verde e São Tomé e Príncipe são microestados insulares, característica que fez com que eles não tivessem guerras de independência, guerras civis ou grandes instabilidades desde 1975. Desse modo, a presente tese contribui tanto para a literatura sobre a África lusófona, ao realizar um estudo descritivo e explicativo sobre as suas transições para a democracia, quanto para a teoria de democratização, reforçando o debate existente entre autores da primeira e segunda geração. Destarte, sugere-se que, apesar da importância da variável externa (expressa pelas pressões internacionais) para impulsionar a transição democrática dos PALOP, o seu sucesso dependeu primordialmente da combinação das suas variáveis domésticas.

Palavras-chave: Democratização, PALOP, microestados insulares, variáveis domésticas, variável externa. 


\begin{abstract}
The Soviet collapse marked a unique historical moment in the world. Amongst its many consequences, it is possible to highlight the political liberalization of a great part of the African continent, which occurred due to the external pressures coming from the main Western powers. Immersed in this scenario, the Portuguese Speaking African Countries (PALOP) presented democratic transitions that have followed distinct trajectories in the last 25 years. In this context, the aim of this thesis is to analyze the PALOP's post-Cold War paths to democratization in order to understand the reasons that caused the success of democracy in the island countries (Cape Verde and Sao Tome and Principe) and its relative lack of success inside the continental ones (Mozambique, Guinea-Bissau and Angola). The research design is focused on a comparative methodology in which the main democratization aspects of these States were analyzed longitudinally, verifying their patterns of similarities and differences through three case studies. Each case covered a distinct historical period, namely the Portuguese colonial rule, the single party regime and the democratization after 1990. Thus, the proven hypothesis is that the democratic success of the insular PALOP is explained by their social, political and economic stability during its process of liberalization and transition to democracy. Likewise, the relative democratic failure of the continental countries occurred due to their social, political and economic instability in the same period. In this scenario, the main variables that influenced this result are related to the fact that Cape Verde and São Tome and Príncipe are insular microstates, since this characteristic influenced the inexistence of independence and civil wars in their territories, mitigating their instabilities since 1975. This thesis contributes both to the literature on the Lusophone Africa, by conducting a descriptive and explanatory study on its transitions to democracy, as well as to the theory of democratization, reinforcing the debate between the first and second generation authors. Therefore, it suggests that despite the importance of the external variable (expressed by the international pressures) to promote the democratic transition inside the PALOP, its success depended primarily on the combination of its domestic variables.
\end{abstract}

Keywords: Democratization, PALOP, insular microstates, domestic variables, external variable. 


\section{LISTA DE ILUSTRAÇÕES}

Figura 1 - Modelo de análise: democratização e intervenção externa..

Figura 2 - Modelo de análise democrática com resultado positivo para Cabo Verde e São

Tomé e Príncipe.

Figura 3 - Modelo de análise democrática com resultado negativo para Moçambique, Guiné-Bissau e Angola. .05

Figura 4 - Escala da democracia nos PALOP em 2015 (FREEDOM HOUSE, 2015).......15

Figura 5 - Democracias no mundo de 1820 a 2012 (POLITY IV). .28

Figura 6 - Fases da democratização - Síntese sobre a definição dos principais conceitos

Figura 7 - Process Tracing: Trajetória democrática dos PALOP. .61

Figura 8 - Modelo de análise: democratização e intervenção externa..............................72

Figura 9 - Liberdade na África (FREEDOM HOUSE, 2016) . .75

Figura 10 - Círculo virtuoso entre crescimento econômico e democracia. .85

Figura 11 - Correlação cross-seccional entre democracia e IDH no período de 2005 a 2010 (BERGGREN, 2012) . .88

Figura 12 - Modelo de análise: democratização e intervenção externa. .226

Figura 13 - Process Tracing: Trajetória democrática dos PALOP insulares. 227

Figura 14 - Process Tracing: Trajetória democrática dos PALOP continentais 228 


\section{LISTA DE GRÁFICOS}

Gráfico 1 - Tipos de Regime Político na África Subsaariana: 1946 - 2012 (CENTER FOR SYSTEMIC PEACE, 2013)

Gráfico 2 - Gráfico sobre democracia de São Tomé e Príncipe de acordo com a Freedom House (2015).

Gráfico 3 - Gráfico sobre democracia de Moçambique de acordo com a Freedom House (2015).

Gráfico 4 - Gráfico sobre democracia da Guiné- Bissau de acordo com a Freedom House (2015).

Gráfico 5 - Gráfico sobre democracia de Angola de acordo com a Freedom House (2015).

Gráfico 6 - Lógicas de comparação científica: casos e aspectos (DESCHOUWER, 2016)

Gráfico 7 - Índice de Democracia Eleitoral dos PALOP de 1900 a 2015 (V-DEM, 2016) .127

Gráfico 8 - Índice de Componentes Liberais dos PALOP de 1900 a 2015 (V-DEM, 2016) 128

Gráfico 9 - Porcentagem da rentabilidade do petróleo em relação ao PIB nos PALOP (BANCO MUNDIAL, 2016)

Gráfico 10 - Ajuda oficial para o desenvolvimento e ajuda oficial recebida (em US\$) pelos PALOP de 1967 a 2015 (WORLD BANK, 2017).

Gráfico 11 - Índice de eleições livres e justas dos PALOP (V-DEM, 2016) 186

Gráfico 12 - Índice de liberdades civis dos PALOP (V-DEM, 2016). 186

Gráfico 13 - IDH dos PALOP de 1980 a 2014 (PNUD).

Gráfico 14 - Voice and accountability dos PALOP de 2005 a 2015 (WORLDWIDE GOVERNANCE INDICATOR, 2017).

Gráfico 15 - Controle da Corrupção nos PALOP 2005 a 2015 (WORLDWIDE GOVERNANCE INDICATOR, 2017). 200

Gráfico 16 - Efetividade do governo nos PALOP (WORLDWIDE GOVERNANCE INDICATOR, 2017) 
Gráfico 17 - Governança nos PALOP (ÍNDICE IBRAHIM DE GOVERNANÇA NA ÁFRICA, 2016). 202

Gráfico 18 - Eleições Presidenciais em Cabo Verde (AFRICAN ELECTIONS, 2016) .205

Gráfico 19 - Eleições Presidenciais em São Tomé e Príncipe (AFRICAN ELECTIONS, 2016) .206

Gráfico 20 - Eleições Presidenciais em Moçambique (AFRICAN ELECTIONS, 2016) .207

Gráfico 21 - Eleições Presidenciais em Guiné-Bissau (AFRICAN ELECTIONS, 2016) .209

Gráfico 22 - Eleições Legislativas em Angola (AFRICAN ELECTIONS, 2016) .210

Gráfico 23- Trajetória democrática de Cabo Verde de 1975 a 2013 (POLITY IV, 2015)

Gráfico 24 - Trajetória democrática de Moçambique de 1975 a 2013 (POLITY IV, 2015)

Gráfico 25 - Trajetória democrática de Guiné-Bissau de 1974 a 2013 (POLITY IV, 2015) .214

Gráfico 26 - Trajetória democrática de Angola de 1975 a 2013 (POLITY IV, 2015) 


\section{LISTA DE TABELAS}

Tabela 1 - As Ondas de Democratização (HUNTINGTON, 1996).................................30

Tabela 2 - Síntese das Teorias de Transição Democrática (LAWSON, 2006).................41

Tabela 3 - Desenho da Mais Semelhança (PRZEWORSKI; TEUNE, 1970)...................56

Tabela 4 - As transições democráticas de Cabo Verde, São Tomé e Príncipe, Angola, Moçambique e Guiné-Bissau em perspectiva comparada.................................................71

Tabela 5 - Classificação da liberdade nas ex-colônias francesas na África........................78

Tabela 6 - Classificação da liberdade nas ex-colônias britânicas na África.......................80

Tabela 7 - Classificação da liberdade nas ex-colônias portuguesas na África...................81

Tabela 8 - Classificação da liberdade nas ex-colônias alemãs na África...........................82

Tabela 9 - Classificação da liberdade nas ex-colônias italianas na África........................83

Tabela 10 - Classificação da liberdade nas ex-colônias belgas na África..........................83

Tabela 11 - Freedom House ratings of micro-states, island states and small island states compared with other states: a summary view (ANCKAR, 2002).......................93

Tabela 12 - Wealth and democracy: small island states compared with other states (ANCKAR, 2002) .......................................................... 94

Tabela 13 - Literacy and democracy: small island states compared with other states (ANCKAR, 2002)..................................................... 95

Tabela 14 - Análise da localização geográfica dos PALOP...........................................109

Tabela 15 - Análise do domínio colonial português nos PALOP..................................115

Tabela 16 - Taxa percentual de crescimento do PIB dos PALOP entre 1951 e 1975 (V-

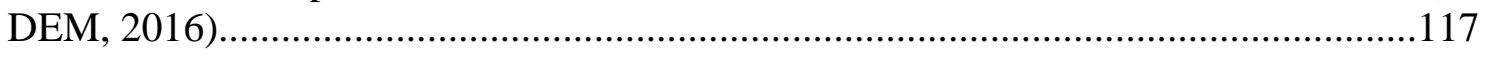

Tabela 17 - PALOP per capita dos PALOP entre 1950 e 1975 (V-DEM, 2016)............118

Tabela 18 - Análise do crescimento econômico dos PALOP durante o regime colonial português.

Tabela 19 - Expectativa de vida dos PALOP entre 1950 e 1975 (V-DEM, 2016).

Tabela 20 - Taxa de mortalidade infantil dos PALOP entre 1960 e 1976 (V-DEM, 2016). 
Tabela 21 - Taxa de analfabetismo dos PALOP em 1958 (FERREIRA, 1974).

Tabela 22 - Análise do desenvolvimento social (relativo) dos PALOP durante o regime colonial português.

Tabela 23 - Análise da variável insularidade/microestado nos PALOP. 125

Tabela 24 - Salários de trabalhadores qualificados em Angola em 1958 - base salarial em escudos (FERREIRA, 1974).

Tabela 25 - Análise dos direitos políticos e liberdades civis dos PALOP durante o regime colonial português.

Tabela 26 - Análise da exploração de longo prazo dos recursos naturais nos PALOP....130

Tabela 27 - Análise da diversidade étnica dos PALOP.

Tabela 28 - Quadro de efetivos do Exército de 1961 a 1973 (AFONSO, 2009). 140

Tabela 29 - Quadro das baixas por morte do Exército de Portugal nas três colônias africanas (FRAGA, 2014).

Tabela 30 - Análise da presença de guerras de independência dos PALOP no pósindependência. 142

Tabela 31 - Independência dos PALOP 144

Tabela 32 - Análise da independência dos PALOP. 144

Tabela 33 - Análise da presença de repúblicas populares de influência soviética nos PALOP. 148

Tabela 34 - Análise dos direitos políticos e liberdades civis dos PALOP durante o regime de partido único. 154

Tabela 35 - PIB per capita dos PALOP entre 1975 e 1990 (V-DEM, 2016)........ 156

Tabela 36 - Análise do crescimento econômico dos PALOP durante o regime de partido único. .158

Tabela 37 - Expectativa de vida dos PALOP entre 1975 e 1990 (V-DEM, 2016). 158

Tabela 38 - Mortalidade infantil dos PALOP entre 1975 e 1990 (V-DEM, 2016).......

Tabela 39 - Quantidade de anos de escolaridade dos cidadãos com mais de 15 anos de idade nos PALOP entre 1975 e 1990 (V-DEM, 2016) 160

Tabela 40 - Análise do desenvolvimento social dos PALOP durante o regime de partido único. 
Tabela 41 - Análise do perfil das elites políticas dos PALOP.

Tabela 42 - Análise da presença de guerra civil nos PALOP no pós-independência (19752015).......

Tabela 43 - Análise da estabilidade social, política e econômica dos PALOP no início da democratização. 178

Tabela 44 - Análise das pressões internacionais para a democratização dos PALOP.....182

Tabela 45 - Análise da liberalização política dos PALOP após a década de 1990. .185

Tabela 46 - Liberdades civis nas Constituições Federais (CF) dos PALOP. 187

Tabela 47 - Direitos políticos nas Constituições Federais (CF) dos PALOP. 189

Tabela 48 - Análise dos direitos políticos e liberdades civis dos PALOP após 1990......190

Tabela 49 - PIB per capita (US\$) dos PALOP entre 1990 e 2016 (V-DEM, 2016 e CIA, 2017)

Tabela 50 - Taxa percentual de crescimento do PIB dos PALOP entre 1990 e 2015 (VDEM e BANCO MUNDIAL, 2016). 192

Tabela 51 - Taxa de inflação dos PALOP de 1990 a 2015 - Porcentagem do Índice de Preços do Consumidor (FMI, 2017). 193

Tabela 52 - Análise do crescimento econômico dos PALOP após 1990 194

Tabela 53 - Expectativa de vida dos PALOP entre 1990 e 2012 (V-DEM, 2016) 195

Tabela 54 - Taxa de mortalidade infantil dos PALOP entre 1990 e 2012 (V-DEM, 2016) 196

Tabela 55 - Quantidade de anos de escolaridade dos cidadãos com mais de 15 anos de idade nos PALOP entre 1975 e 1990 (V-DEM, 2016). 197

Tabela 56 - Análise do desenvolvimento social (relativo) dos PALOP após 1990..........198

Tabela 57 - Análise da criação de instituições democráticas fortes dos PALOP .203

Tabela 58 - Análise da alternância de poder e controle dos civis sobre os militares nos PALOP.

Tabela 59 - Fases da trajetória política dos PALOP de acordo com o African Elections (2016) 216

Tabela 60 - Análise da presença da democracia liberal dos PALOP em 2016. .217

Tabela 61 - Análise comparada dos PALOP no período colonial. 219 
Tabela 62 - Análise comparada dos PALOP no período colonial sem as variáveis de controle.

Tabela 63 - Análise comparada dos PALOP no período do regime de partido único.....221

Tabela 64 - Análise comparada dos PALOP no período da democratização (pós1990)......

Tabela 65 - Análise comparada dos PALOP de 1950 a 2015 sem as variáveis de controle. .225

Tabela 66 - Análise tipológica comparada dos PALOP de 1950 a 2015 sem as variáveis de controle.

Tabela 67 - Análise comparada dos PALOP considerando a variável externa, a variável independente principal e a variável dependente. .226 


\section{LISTA DE SIGLAS}

ADI: Ação Democrática Independente

CEDEAO: Comunidade Econômica dos Estados da África do Ocidente

EUA: Estados Unidos da América

FDC: Frente Democrática Cristã

FMI: Fundo Monetário Internacional

FNLA: Frente Nacional de Libertação de Angola

FRELIMO: Frente de Libertação de Moçambique

IIAG: Índice Ibrahim de Governança Africana

MLSTP: Movimento para a Libertação de São Tomé e Príncipe

MDFM-PL: Movimento Democrático Força da Mudança - Partido Liberal

MLSTP-PSD: Movimento para a Libertação de São Tomé e Príncipe - Partido Social Democrata

MpD: Movimento para a Democracia

MPLA: Movimento Popular de Libertação de Angola

ONU: Organização das Nações Unidas

PAICV: Partido Africano da Independência de Cabo Verde

PAIGC: Partido Africano para a Independência da Guiné e Cabo Verde

PALOP: Países Africanos de Língua Oficial Portuguesa

PCD-GR: Partido Convergência Democrática - Grupo Reflexão

PLS: Partido Liberal Social

PRS: Partido da Renovação Social

UNITA: União Nacional para a Independência Total de Angola

URSS: União das Repúblicas Socialistas Soviéticas

V-DEM: Variables of Democracy 
PARTE I - ASPECTOS TEÓRICOS E METODOLÓGICOS PARA A ELABORAÇÃO DO ESTUDO SOBRE A DEMOCRATIZAÇÃO DOS PALOP NO PÓS-GUERRA FRIA...............................................................................................21

CAPÍTULO 1 - DEMOCRACIA E COMPONENTES DA DEMOCRATIZAÇÃO: UMA ABORDAGEM TEÓRICA.............................................................................22

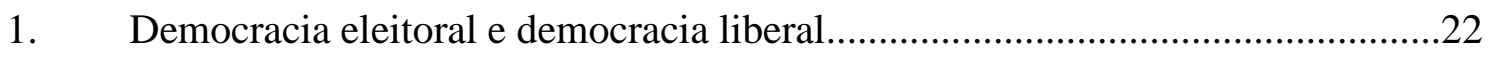

2. As Ondas de Democratização e as transições democráticas no pós-Guerra Fria.. .25

3. As diferentes fases da democratização: liberalização, transição democrática e consolidação da democracia.

4. Primeira fase da democratização: liberalização política......................................32

5. Segunda fase da democratização: transição democrática......................................33

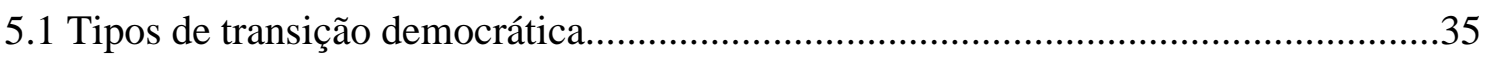

6. O debate sobre o impacto das variáveis internas e externas nos processos de

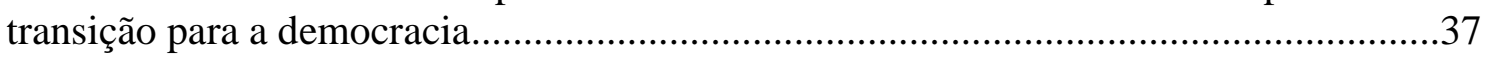

7. Transição democrática e ajuda internacional: diálogos e

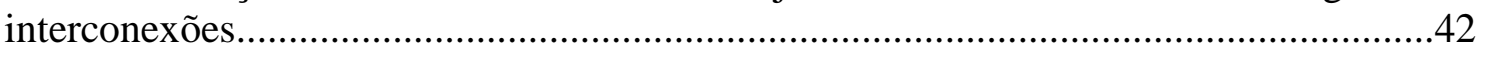

8. Terceira fase da democratização: consolidação democrática.................................45

CAPÍTULO 2 - O MÉTODO COMPARADO COMO UM INSTRUMENTO DE ANÁLISE DA DEMOCRATIZAÇÃO DA ÁFRICA LUSÓFONA.........................52 
Parte I - Política Comparada no contexto de democratização dos PALOP

1. A aplicação do método comparado aos processos de democratização dos PALOP no

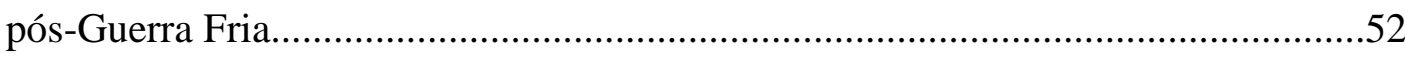

2. Modelos de Comparação e desenho de pesquisa da tese...........................................56

3. Construção da cadeia causal baseada na democratização dos PALOP......................58

\section{Parte II - Análise das variáveis que integram a cadeia causal}

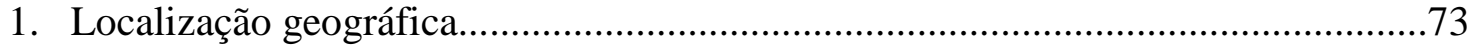

2. Domínio português (colonização portuguesa)..........................................................76

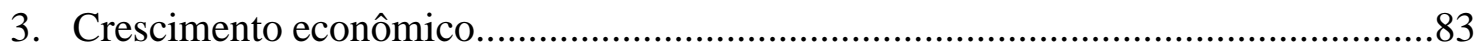

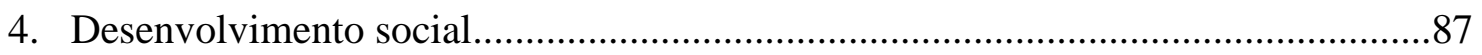

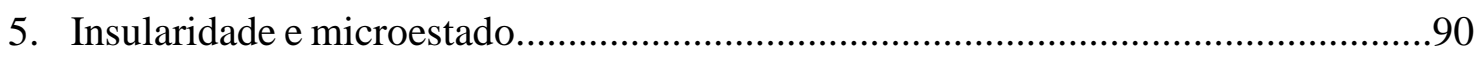

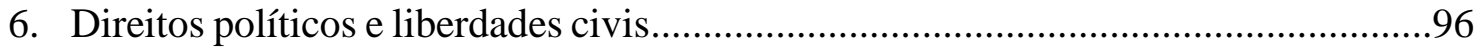

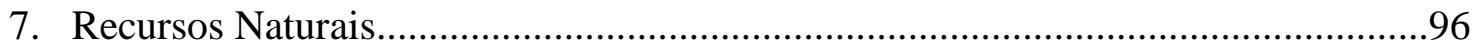

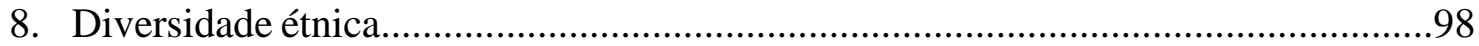

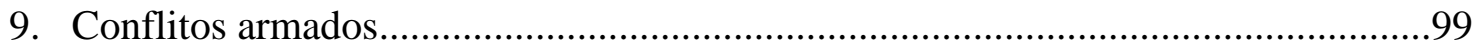

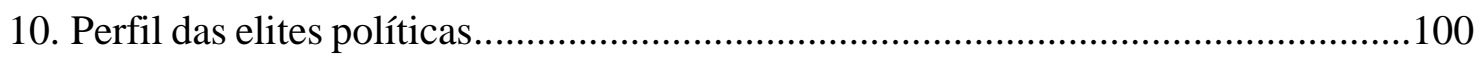

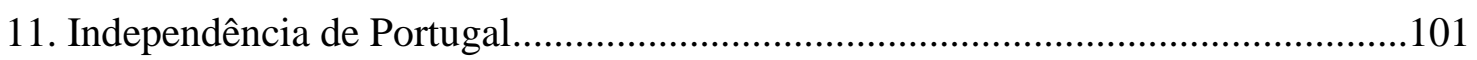

12. Repúblicas Populares de influência soviética......................................................102

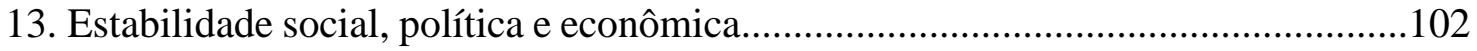

14. Pressões internacionais para a democratização.......................................................103

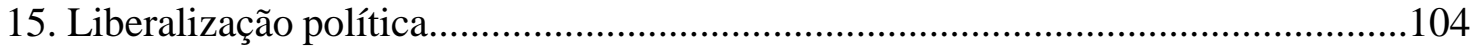

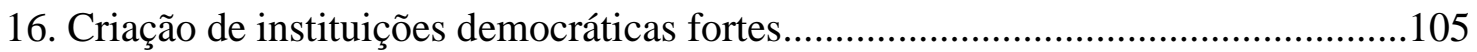

17. Alternância de poder e controle dos civis sobre os militares...................................105

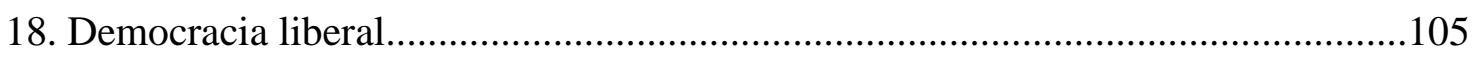

PARTE II - ANÁliSE DOS PROCESSOS DE DEMOCRATIZAÇÃo DOS PALOP NO PÓS-GUERRA FRIA..................................................................................107 


\section{CAPÍtulo 3 - ESTUdo DE CASO 1: DOMINAÇÃO COLONIAL PORTUGUESA NA ÁFRICA DURANTE O SÉCULO XX......................................108}

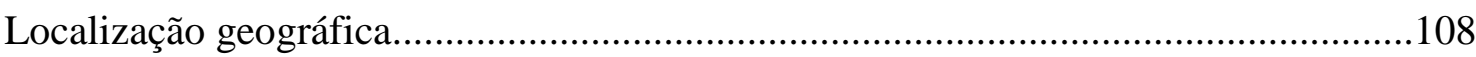

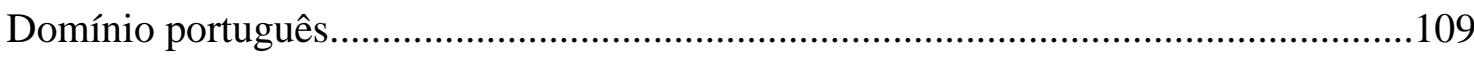

Crescimento econômico durante o período colonial português......................................115

Desenvolvimento social durante o período colonial...................................................119

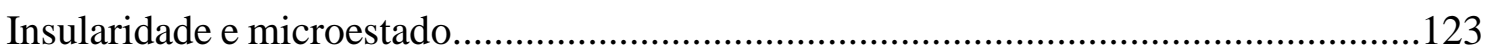

Direitos políticos e liberdades civis durante o período colonial....................................125

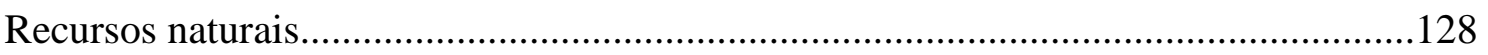

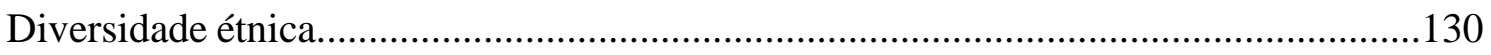

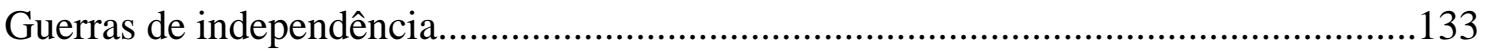

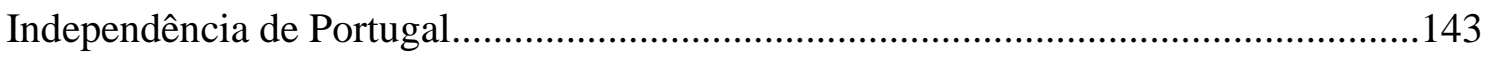

CAPÍTULO 4 - ESTUDO DE CASO 2: O REGIME DE PARTIDO ÚNICO NOS PALOP. .146

Repúblicas Populares de influência soviética...........................................................146

Direitos políticos e liberdades civis durante o regime de partido único..........................148

Crescimento econômico dos PALOP durante o regime de partido único........................155

Desenvolvimento social dos PALOP durante o regime de partido único........................158

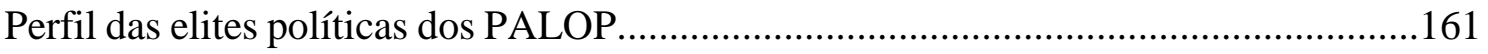

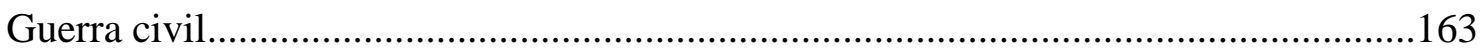

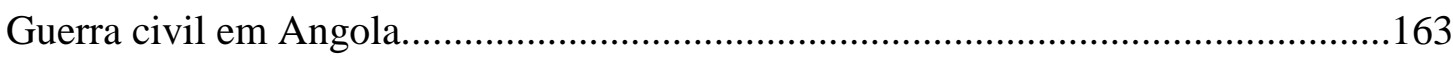

Guerra civil em Moçambique - “A Guerra dos 16 Anos".........................................169

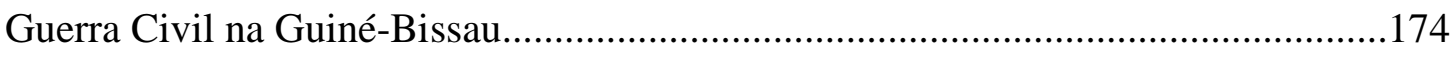




\section{CAPÍTULO 5 - ESTUDO DE CASO 3: A DEMOCRATIZAÇÃO DOS PALOP NO

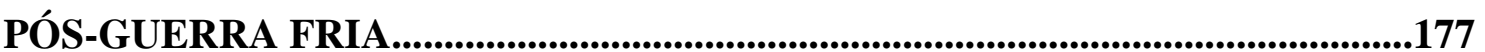

Período histórico: início da democratização no final da década de 1980 e começo de 1990

Estabilidade social, política e econômica no início da democratização.

Pressões internacionais para a democratização dos PALOP após o fim da Guerra Fria

Período histórico: liberalização e transição democráticas após 1990

Liberalização política

Direitos políticos e liberdades civis durante a democratização

Crescimento econômico após 1990

Desenvolvimento social após 1990. 194

Criação de instituições democráticas fortes. 198

Alternância de poder e controle dos civis sobre os militares

Democracia liberal

CONSIDERAÇÕES FINAIS. 218

REFERÊNCIAS BIBLIOGRÁFICAS. 232

ANEXOS. 
ANEXO B - DEMOCRATIZAÇÃO NA ÁFRICA DE ACORDO COM A FREEDOM HOUSE E COM O POLITY IV

ANEXO C - DADOS SOBRE A ÁFRICA: GEOGRAFIA, COLONIZAÇÃO E IDH.

ANEXO D - ATO COLONIAL: DECRETO-LEI No 22.465 DE 11 DE ABRIL DE 1933. .256

ANEXO E - TRAJETÓRIA ELEITORAL DOS PALOP DE 1975 A 2017. 261 ANEXO F - RECEBIMENTO DE AJUDA OFICIAL DOS PALOP DE 1967 A 2015 


\section{INTRODUÇÃO}

A presente Tese de Doutorado tem como objetivo analisar as trajetórias democráticas dos Países Africanos de Língua Oficial Portuguesa (PALOP) ${ }^{1}$ no pósGuerra Fria visando a compreender o sucesso da democracia nos PALOP insulares (Cabo Verde e São Tomé e Príncipe) e o seu relativo insucesso nos PALOP continentais (Moçambique, Guiné-Bissau e Angola). Desse modo, este trabalho almeja contribuir para a literatura sobre as ex-colônias portuguesas na África ao realizar um estudo descritivo e explicativo sobre as suas transições para a democracia, avaliando de maneira longitudinal as variáveis que influenciaram o êxito ou fracasso do seu processo democrático. Além disso, também contribuirá para a teoria de democratização, reforçando o debate existente entre autores da primeira e segunda geração, avaliando o papel das variáveis domésticas e externas nas transições democráticas dos PALOP.

Dessa forma, a pergunta desta pesquisa é: por que a transição democrática obteve sucesso nos PALOP insulares e insucesso nos PALOP continentais? ${ }^{2}$ Para responder a esse questionamento, será utilizada a metodologia comparada, na qual serão verificados os principais aspectos das democratizações de Cabo Verde, São Tomé e Príncipe, Angola, Moçambique e Guiné-Bissau, identificando os seus padrões de similaridades e diferenças. Destarte, a hipótese principal a ser comprovada é a de que o sucesso democrático dos PALOP insulares se explica devido à sua estabilidade social, política e econômica durante o processo de liberalização e transição democrática. Da mesma forma, o insucesso

\footnotetext{
${ }^{1}$ Desde 2015 a Guiné-Equatorial passou a fazer parte dos PALOP. Devido ao caráter histórico de colonização portuguesa que se pretende escrutinizar nessa pesquisa, o referido país não será estudado e não abarcará o conjunto dos Estados aqui referidos como PALOP.

2 António Costa Pinto (2001) destaca o reduzido universo dos estudos realizados sobre a África lusófona após 1975, afirmando que: "Como o escreveu recentemente Wm. Roger Louis, "na história das descolonizações, Portugal é o elo fraco". Fraqueza provocada pelo simples fato dos especialistas do tema raramente incluírem o caso português e dos que trabalham o tema para o caso português não o pensarem numa perspectiva comparada" (PINTO, 2001, p. 09). A pesquisa realizada na presente tese também se justifica porque não há qualquer estudo sistematizado sobre todos os PALOP no âmbito das suas transições democráticas. Dessa forma, ela contribuirá tanto para a literatura sobre os estudos contemporâneos da África lusófona, que ainda se encontram em um estágio formativo relativamente incipiente, quanto para a literatura sobre democratização. A democracia, que de maneira geral é colocada em um segundo plano na produção acadêmica das Relações Internacionais, ganha destaque nesse estudo ao evidenciar que, mais do que um regime político, ela constituiu-se em uma variável importante para compreender a Nova Ordem Mundial do pós-Guerra Fria e a formação da sua agenda global múltipla. Dessa forma, a Teoria da Paz Democrática e as teorias sobre democratização se apresentam fundamentais para a análise da inserção internacional dos PALOP após 1990, contribuindo para o seu reposicionamento no tabuleiro político global.
} 
democrático dos PALOP continentais se explica pela instabilidade social, política e econômica durante o processo de liberalização e transição democrática durante esse mesmo período. Para compreender a construção da tese e as principais premissas que a sustentam, é necessário contextualizar a sua elaboração, que se baseia na continuidade da dissertação de mestrado da autora ${ }^{3}$.

No referido trabalho, foi estudada a transição para a democracia liberal em países que sofreram uma intervenção militar norte-americana direcionada a instaurar esse novo regime político. Nesse universo, os casos escolhidos para a análise da democratização pelo uso da força apresentavam localizações geográficas e temporais significativamente distintas. O primeiro grupo era representado por países que tiveram sucesso na imposição da sua transição democrática, englobando Japão e Alemanha depois da II Guerra Mundial. Já o segundo grupo representava casos de insucesso, abarcando Afeganistão e Iraque após 11 de setembro de 2001.

Na investigação, descobriu-se que, apesar da importância que a variável externa teve para impulsionar a democracia, o seu êxito dependia essencialmente de um conjunto de variáveis domésticas, que combinadas, resultavam na estabilidade política, econômica e social desses países no momento da democratização. Como resultado, o estudo permitiu a criação de um modelo para testar o sucesso ou insucesso da democratização nos países que iniciaram a sua liberalização e transição democrática por meio da intervenção de uma variável externa, a saber:

\footnotetext{
${ }^{3}$ Este trabalho encontra-se na bibliografia desta tese como "QUEIROZ, Thais de O. A exportação da democracia liberal pelo uso da força: uma análise comparada dos casos da Alemanha, Japão, Afeganistão e Iraque. Dissertação de Mestrado. Instituto de Relações Internacionais, Universidade de Brasília. Brasília, 2012”.
} 


\section{Figura 1 - Modelo de análise: democratização e intervenção externa}

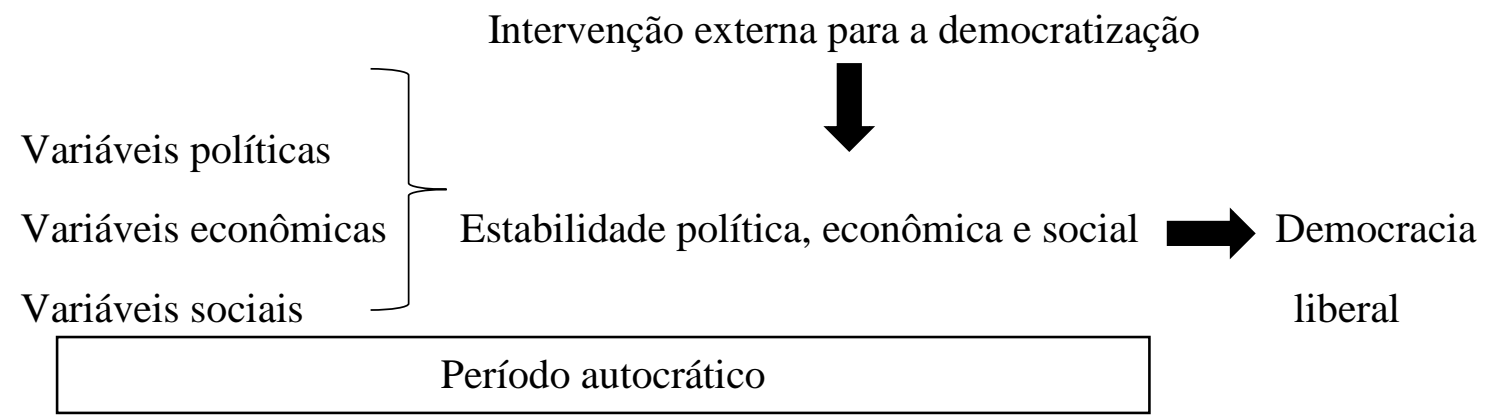

Fonte: Figura elaborada pela autora utilizando-se como base o modelo de análise desenvolvido na sua Dissertação de Mestrado (QUEIROZ, 2012).

O referido modelo exprimiu resultados positivos para a Alemanha e o Japão, que possuíam um conjunto de variáveis domésticas que propiciava uma relativa estabilidade política, econômica e social no momento da democratização, resultando no êxito da transição democrática e instauração da democracia liberal. Já os seus resultados foram negativos para o Afeganistão e o Iraque, que apresentavam instabilidade política, econômica e social no momento da democratização, resultando no insucesso da transição democrática e instauração de uma autocracia permeada por elementos democráticos mínimos, expressos na implantação de alguns direitos políticos ${ }^{4}$. Por ter se revelado um modelo que permitiu, de maneira fidedigna e robusta, extrair resultados importantes para explicar o papel das variáveis domésticas e externas nos processos de democratização realizados por meio de uma intervenção externa, decidiu-se, nesse estudo de doutoramento, testá-lo à realidade de outros países que tivessem perpassado situações semelhantes.

\footnotetext{
${ }^{4}$ De acordo com a autora, as conclusões do trabalho podem ser descritas da seguinte maneira: "O sucesso da transição democrática (e consequente consolidação) da Alemanha e do Japão foi possível porque os dois países possuíam uma determinada combinação de variáveis internas, na qual se observou a existência de estabilidade política, potencial desenvolvimento econômico e homogeneidade étnica, religiosa e cultural no momento da intervenção norte americana. Ao apresentarem um contexto interno de instabilidade política, heterogeneidade étnica, religiosa e cultural, além de baixo potencial de desenvolvimento econômico no momento da intervenção estrangeira, o Afeganistão e o Iraque continuaram vivenciando um cenário doméstico caótico mesmo depois da atuação das coalizões para a imposição da democracia. Desse modo, foi observado que essa combinação específica de variáveis domésticas, advindas de fatores sociais, econômicos e políticos, facilitou ou dificultou a concretização da transição democrática nos contextos em que a democracia foi imposta pelo uso da força, evidenciando que o cenário doméstico desses países foi essencial para explicar o êxito ou fracasso da democratização" (QUEIROZ, 2012, p. 157). Para maiores informações sobre esta investigação, ver o Anexo A.
} 
A seleção de casos para serem aplicados ao modelo foi complexa, pois deveria incluir um conjunto de países que apresentassem as seguintes características:

a) a sua democratização deveria ter sido impulsionada por uma variável externa;

b) os países deveriam apresentar um conjunto de características similares para que a comparação pudesse ser realizada de maneira consistente e

c) os resultados da democratização deveriam ser diferentes, permitindo a análise tipológica em casos de sucesso e de fracasso democrático, de modo a evitar o viés de seleção.

Nesse cenário, os PALOP se encaixaram em todos esses requisitos, com a exceção de um aspecto singular da sua variável externa, tendo em vista que ela não se caracterizava pela democratização por meio do uso da força, conforme observado na Alemanha, Japão, Afeganistão e Iraque, mas nas pressões internacionais das potências do Ocidente para a implantação da democracia em um contex to de soft power. Essa definição é importante porque, se modelo for confirmado no âmbito dos PALOP, ele poderá ser utilizado futuramente de maneira mais ampla, podendo explicar o sucesso ou insucesso de todos ou da maior parte dos casos nos quais as transições democráticas ou foram impulsionadas ou por meio de uma intervenção militar ou ocorreram pautadas em algum instrumento de soft power.

Dessa forma, a hipótese desse trabalho se concretizaria da seguinte maneira na aplicação dos casos dos PALOP ao modelo proposto: os PALOP insulares apresentariam um resultado positivo enquanto os PALOP continentais apresentariam um resultado negativo, conforme se observa nas figuras 2 e 3 : 
Figura 2 - Modelo de análise democrática com resultado positivo para Cabo Verde e São Tomé e Príncipe

Intervenção externa para a democratização

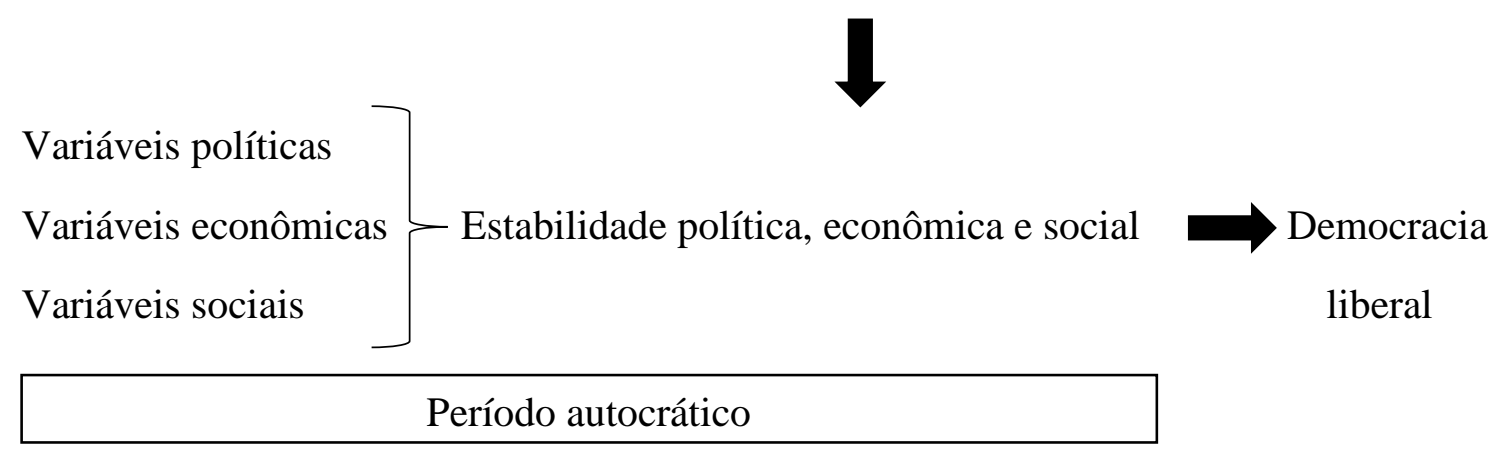

Fonte: Figura elaborada pela autora.

Figura 3 - Modelo de análise democrática com resultado negativo para Moçambique, Guiné-Bissau e Angola

Intervenção externa para a democratização

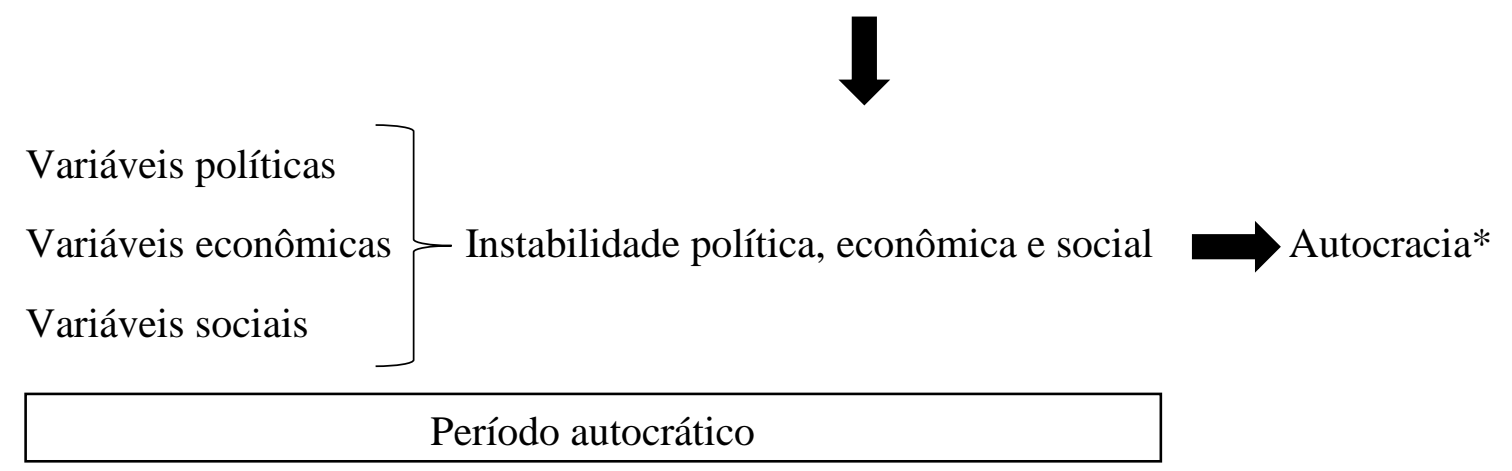

*Autocracia ou anocracia com elementos democráticos, notadamente no âmbito dos direitos políticos. Esses conceitos serão explicados a seguir no âmbito do Polity IV.

Fonte: Figura elaborada pela autora.

\section{Metodologia para testar o Modelo}

A metodologia utilizada para testar o supracitado modelo pautou-se na comparação, tendo o seu desenho de pesquisa influenciado pelo método da "Mais 
Semelhança" de Przeworski e Teune (1971). Dessa forma, construiu-se uma cadeia causal por meio do process tracing na qual variáveis políticas, econômicas e sociais foram analisadas de maneira longitudinal em três momentos históricos específicos: a) período colonial, b) período do regime de partido único e c) período da democratização (pós1990). É importante destacar que esses aspectos metodológicos serão abordados de maneira detalhada no Capítulo 2 desta tese.

Nesse contexto, a estrutura de análise da tese será pautada na comparação de todos os PALOP, considerando os resultados de cada variável exposta na cadeia causal por meio de três estudos de caso. O primeiro deles será focalizado no período da colonização portuguesa entre 1950 e 1975, o segundo, no período do sistema monopartidário de influência soviética e, finalmente, o terceiro abordará o momento da liberalização e transição para a democracia.

\section{Análise das variáveis}

Para realizar a análise da democracia liberal, que se configura como a variável dependente da cadeia causal elaborada para a presente investigação, foram escolhidos três indicadores: Freedom House, Polity IV e V-DEM. Cada um desses indicadores será estudado a seguir, propiciando compreender o seu significado nos gráficos expostos ao longo da tese.

\section{Indicadores Democráticos: Freedom House, Polity IV e V-Dem}

A criação de indicadores que tem como finalidade mensurar a qualidade da democracia é um tema polêmico para os estudiosos das teorias de democratização ${ }^{5}$. Isso ocorre porque os indicadores apresentam limitações e, por trabalharem com modelos ideais, nem sempre conseguem exprimir de maneira verídica todos os aspectos da

\footnotetext{
${ }^{5}$ Ao analisar os indicadores que mensuram a questão democrática, Gugliano (2013) afirma que "não são poucos aqueles que acentuam a parcialidade de grande parte desses sistemas classificatórios que, algumas vezes, reduzem a compreensão de o que é a democracia a critérios eleitorais ou institucionais. Há muitas críticas à metodologia dessas pesquisas, assim como desconfiança sobre a objetividade das mesmas frente à necessidade de avaliar especialmente governos abertamente de esquerda" (GUGLIANO, 2013, p. 213).
} 
realidade de determinado país. Apesar das críticas, eles representam um instrumento importante para a análise da democracia, fornecendo parâmetros fundamentais para a compreensão da trajetória democrática dos mais diversos países no mundo. Um dos indicadores mais utilizados na literatura de democratização é o da Freedom House, que engloba aspectos tanto das liberdades civis quanto dos direitos políticos. O Polity IV também é outro indicador amplamente aplicado, sendo mais focalizado no universo dos direitos políticos. Atualmente, o recém-criado V-Dem tem o potencial de impulsionar ainda mais o conhecimento nesse campo de estudos, fornecendo uma compilação de qualidade das mais distintas bases de dados sobre democracia (incluindo a Freedom House e o Polity IV). Antes de apresentar a configuração de cada indicador, mais uma vez é importante destacar que não existe uma metodologia de mensuração da democracia que seja perfeita. Entretanto, mesmo repletos de questionamentos e problemas, esses indicadores atuam como instrumentos fundamentais para compreender e comparar a trajetória democrática dos mais diversos países do mundo ao longo dos anos.

A Freedom House realiza a classificação dos países em "livres", "parcialmente livres" e "não-livres", de acordo com um indicador que varia entre 1 (o mais livre) e 7 (o menos livre). Os "livres" são classificados entre 1,0 e 2,5; os "parcialmente livres" entre 3,5 e 5,0 e os "não-livres", entre 5,5 e 7,0. De acordo com a instituição, a liberdade é definida como a oportunidade de agir espontaneamente em vários campos que estejam fora do controle do governo ou outros centros de dominação. Sendo assim, ela é medida em termos de direitos políticos e de liberdades civis. Os direitos políticos possibilitam aos cidadãos a livre participação no processo político, seja por meio do voto, da competição para cargos públicos ou do direito a eleger representantes que tenham impacto decisivo nas políticas públicas. Já as liberdades civis encontram-se relacionadas à liberdade de expressão, de crença e de associação, da garantia do estado de Direito e à autonomia pessoal frente à interferência do Estado (FREEDOM HOUSE, 2015).

Já o Polity Data Series é reconhecido por abarcar uma série de dados amplamente pautados no campo da Ciência Política. Iniciado na década de 1970 na University of Maryland, o Polity Project foi fundado por Ted Robert Gurr e atualmente se encontra sob a direção de Monty G.Marshall, no Center for Systemic Peace da George Mason University, nos Estados Unidos da América. Baseando-se em padrões de autoridade e nas mudanças de regimes políticos em todos países independentes do globo que possuem uma 
população maior do que cem mil habitantes, o empreendimento mensura os níveis de democracia e autocracia no mundo. De acordo com o relatório de 2011, "the Polity project has proven its value to researchers over the years, becoming the most widely used data resource for studying regime change and the effects of regime authority" (POLITY IV REPORT, 2016, p. 01).

O Polity IV, no que tange ao nível de democracia de um Estado, avalia indicadores específicos mais relacionados aos direitos políticos do que às liberdades civis, pautando-se no recrutamento do Executivo e nos constrangimentos às autoridades executivas e à competição política (sendo esta competitividade refletida nas eleições nacionais, na abertura do regime e no nível de participação). Ao invés de classificar os países como "livres", parcialmente "livres" ou "não-livres", utiliza seis diferentes categorias democráticas, oferecendo para cinco delas uma pontuação específica que varia de -10 a +10 . As democracias completas (full democracies) recebem dez pontos; as democracias (democracy) recebem de seis a nove pontos; as anocracias abertas (open anocracies) recebem de um a cinco pontos; as anocracias fechadas (closed anocracies) recebem de -5 a zero ponto; já as autocracias (autocracies), recebem de -10 a -6 pontos. As anocracias englobam um quadro amplo e complexo, sendo concebidas como regimes mistos, incoerentes ou autoritários. Finalmente, tem-se que os países fracassados ou ocupados, que não recebem qualquer pontuação. Observa-se que a metodologia adotada pelo Polity IV utiliza um espectro de vinte e um pontos, no qual -10 pontos representa as monarquias hereditárias e +10 pontos, as democracias consolidadas.

O Varieties of Democracy, cuja sigla é V-DEM, constitui uma base de dados que tem como objetivo fornecer uma nova forma de mensurar a democracia. Dessa forma, utilizando-se de mais de 350 indicadores relacionados à democracia e aos sistemas políticos, analisa todos os países do mundo fornecendo informações que, quando possível, se iniciam em 1900. Dessa forma, apresenta uma base de dados ampla, multidimensional e desagregada, que leva em consideração sete princípios fundamentais da democracia, a saber: eleitoral, liberal, participativa, deliberativa, igualitária, majoritária e consensual. O V-DEM é formado por um grupo de mais de 50 cientistas sociais localizados nos seis continentes, que trabalham conjuntamente com mais de 2.500 especialistas de todos os países do mundo, disponibilizando uma base de dados transparente e de qualidade, que 
tem o potencial de impulsionar de maneira contundente as informações disponíveis para futuros estudos sobre democratização (V-DEMa, 2016).

\section{Base de dados políticos, econômicos e sociais}

Além dos indicadores democráticos, o presente estudo utilizou a base de dados do Banco Mundial, do Fundo Monetário Internacional (FMI), do African Elections, do Worldwide Governance Indicators e do Índice Ibrahim de Governança na África (IIAG) para analisar as variáveis políticas, econômicas e sociais dos PALOP. A maneira que cada base de dados ou indicador foi aplicado constitui-se da seguinte maneira:

a) Indicadores utilizados para mensurar a democracia:

- Freedom House;

- Polity IV;

- V-DEM.

b) Base de dados utilizada para analisar as eleições nos PALOP:

- African Elections.

c) Base de dados utilizada para analisar a qualidade da democracia nos PALOP:

- Worldwide Governance Indicators e

- Índice Ibrahim de Governança na África (IIAG).

d) Bases de dados utilizadas para obter informações sobre as questões econômicas e sociais dos PALOP:

- Banco Mundial;

- Fundo Monetário Internacional (FMI);

- V-DEM. 
A primeira parte da presente Introdução permitiu compreender o contexto de elaboração da tese, analisando as premissas que explicam a construção do seu objetivo e da sua hipótese. A seguir, serão estudadas as características dos PALOP que justificam a sua escolha para testar o supracitado modelo.

\section{Contexto de similaridades dos PALOP}

Conforme mencionado anteriormente, os PALOP deveriam apresentar três características essenciais para fazerem parte desse estudo, a saber: a sua democratização deveria ter sido impulsionada por uma variável externa; eles deveriam apresentar um conjunto de características similares para que a comparação pudesse ser realizada de maneira consistente e, finalmente, os resultados da democratização deveriam ser diferentes, permitindo a análise tipológica em casos de sucesso e de fracasso democrático, de modo a evitar o viés de seleção. Considerando esses aspectos, cada uma dessas características será analisada de maneira detalhada, visando a compreender o referido processo de escolha dos casos.

\section{Democratização impulsionada por uma variável externa}

A primeira característica compartilhada pelos PALOP que foi fundamental para essa investigação refere-se, como mencionado anteriormente, ao fato de que a sua democratização foi impulsionada em 1990 pela influência de uma variável externa, representada por meio das pressões internacionais advindas das potências ocidentais (notadamente Estados Unidos e Europa). Para abordar esse tema, será realizada uma análise teórica e histórica do momento de transição democrática dos PALOP, contextualizando o papel da referida variável no escopo deste estudo.

De acordo com Huntington (1996), uma onda de democratização consiste em um determinado período de tempo no qual a quantidade de democracias ultrapassa de forma expressiva o número de autocracias. Considerando essa definição específica, observa-se que as transições democráticas dos PALOP se encontram dentro do contexto da Terceira Onda de Democratização, fenômeno que resultou na adoção do regime democrático por mais da metade dos países do mundo. Seu início ocorreu em Portugal 
durante a Revolução dos Cravos, tendo se alastrado rapidamente pelo globo, notadamente Europa meridional, América Latina, e o leste, sudeste e sul da Ásia. Como consequência deste fenômeno, pelo menos trinta países se tornaram democráticos entre os anos de 1974 e 1990.

Na década de 1990 os processos de democratização ao redor do mundo se aprofundaram significativamente, influenciados por eventos como o colapso da União das Repúblicas Socialistas Soviéticas (URSS) e das Europas do Leste e Central e pela emergência do regime democrático em países da América Central e da África Subsahaariana (HUNTINGTON, 1996). O período que marcou o início de grande parte das transições democráticas ocorridas na África na década de 1990 ficou conhecido como Primavera Africana (KOUDAWO, 2001), sendo este o contexto de tempo e espaço no qual o presente estudo se encontra focalizado. Conforme se observa no gráfico abaixo, a quantidade de países da África Subsaariana que realizaram a democratização no pósGuerra Fria foi expressiva, resultando em um grande número de anocracias e democracias. Com o passar do tempo, principalmente no início do século XXI, observouse que as democracias apresentaram uma curva ascendente, enquanto as anocracias e autocracias demonstravam um relativo declínio, a saber:

Gráfico 1 - Tipos de Regime Político na África Subsaariana: 1946 - 2012 (CENTER FOR SYSTEMIC PEACE, 2016)

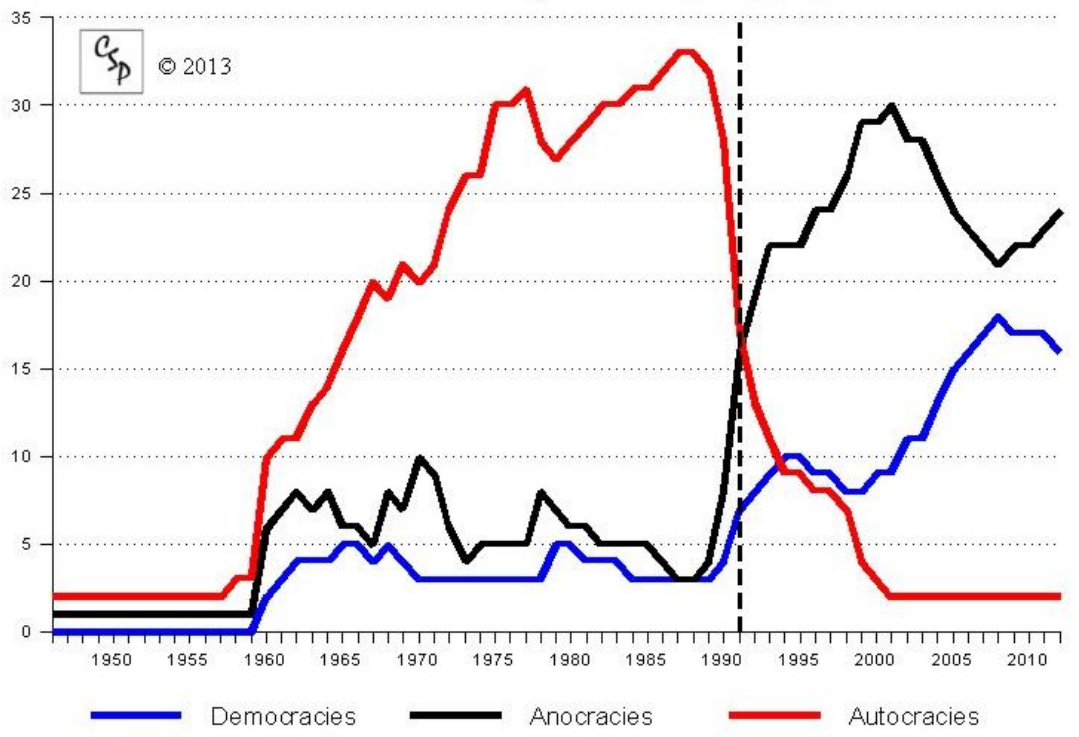

Fonte. CENTER FOR SYSTEMIC PEACE, 2016, s.p. 
O arranjo global que se estabeleceu após a vitória norte-americana na Guerra Fria consistiu na concepção da democracia como o regime político desejável (visto que democracias não entrariam em conflito entre $\mathrm{si}^{6}$ ) no escopo da implementação do liberalismo econômico, que serviria como uma ferramenta para impulsionar o comércio internacional, intensificando a globalização. Nesse cenário, os Estados que anteriormente se encontravam sob a influência soviética se depararam com a drástica redução dos recursos financeiros advindos da URSS, fator que os compeliu a transformar a sua agenda doméstica de modo a se encaixarem nas novas "regras do jogo" da arena internacional.

Tornar-se democrático e promover a abertura econômica passou a ser basilar para receber ajuda externa, participar do comércio internacional e dos espaços privilegiados de negociação da Nova Ordem Mundial. Como resultado, um conjunto idiossincrático de ideologias e o modus operandi social, político e econômico que prevaleceu por décadas nas nações ex-comunistas tiveram que ser substituídos por premissas democráticas e relações econômicas profundamente distintas das praticadas por eles durante a maior parte da segunda metade do século XX.

Entre as dezenas de nações que receberam os mais variados incentivos seletivos para reestruturarem a sua conjuntura doméstica para o modelo capitalista e democrático, insere-se o idiossincrático conjunto dos Estados lusófonos na África. Ao se adaptarem a esse cenário dinâmico da arena internacional, cada PALOP construiu de maneira singular a sua própria trajetória democrática, que apresentou um complexo cenário de êxitos e insucessos.

A questão que se configurava nesse momento para as antigas colônias portuguesas era: como participar e se adaptar ao novo tabuleiro global? A inserção internacional era necessária e a transição democrática se delineava como um caminho facilitador desse processo. Koudawo (2001) defende esse argumento ao afirmar que

Em 1990-1991, quando se realiza a transição cabo-verdiana, o contexto internacional é o do choque experimentado pelo mundo após a queda do muro de Berlim. A dominante das condicionalidades dos doadores internacionais era a legitimidade democrática. (KOUDAWO, 2001, p. 161).

\footnotetext{
${ }^{6}$ Este é o preceito basilar da Teoria da Paz Democrática, conforme exposto por Doyle (1986). Para o autor, a democracia é essencial para o estabelecimento da harmonia e estabilidade do meio internacional.
} 
Conforme exposto, tem-se que as pressões internacionais do pós-Guerra Fria fizeram com que os PALOP iniciassem o seu processo de democratização visando a se adequarem às novas questões colocadas na agenda mundial, que tinham a democracia como um requisito fundamental para legitimar a atuação dos países na Nova Ordem que se delineava.

\section{Compartilhamento de um conjunto de características similares}

Além da similaridade de terem realizado a democratização por influência da mesma variável externa no mesmo período de tempo, os PALOP apresentam um conjunto de similaridades consistentes que permitem a realização da sua comparação inspirada em um modelo de "Mais Semelhança", conforme será abordado de maneira detalhada no Capítulo 2 da tese.

A primeira característica compartilhada por todos os PALOP refere-se à questão geográfica, tendo em vista que todos se localizam no continente africano. Destaca-se também que todos foram colonizados por Portugal e compartilham o idiossincrático legado colonial português, o que fez com que todos eles obtivessem a sua independência em um período de tempo muito próximo (1973 para Guiné-Bissau e 1975 para os outros PALOP), logo após a Revolução dos Cravos e a consequente queda da ditadura em Portugal no ano de 1974 (com a exceção da independência guineense).

Outro fator importante situa-se no fato de que as lideranças políticas no pósindependência governaram esses países sob a égide de partidos marxistas-leninistas, que foram responsáveis pelas lutas de libertação. Esse cenário resultou na contundente influência soviética no universo dos PALOP, que instauraram Repúblicas Populares pautadas em características autocráticas e monopartidárias que perduraram de 1973/1975 até a década de 1990. Nesse sistema de partido único, o Partido Africano para a Independência da Guiné e Cabo Verde (PAIGC) e o Partido Africano da Independência de Cabo Verde (PAICV) dominaram Cabo Verde (O PAIGC cedeu lugar ao PAICV em 1980), o Movimento para a Libertação de São Tomé e Príncipe (MLSTP) governou São

Tomé e Príncipe, o PAIGC se estabeleceu na Guiné-Bissau, a Frente de Libertação de 
Moçambique (FRELIMO) permaneceu no poder em Moçambique e, finalmente, o Movimento Popular de Libertação de Angola (MPLA) governou Angola.

No início da Nova Ordem Mundial pós-1990, influenciados pelas pressões internacionais supracitadas decorrentes do fim da Guerra Fria, os cinco países iniciaram, quase que simultaneamente, os seus processos de democratização, que foram realizados em um primeiro momento por meio da implantação do pluripartidarismo. É importante destacar que, ao contrário de muitos países africanos que tiveram breves experiências liberais no pós-independência, os PALOP nunca tiveram qualquer experiência democrática anterior à década 1990 (KOUDAWO, 2001).

Além do multipartidarismo, um conjunto de outros direitos políticos e de liberdades civis passou a fazer parte da Constituição dos PALOP no pós-Guerra Fria. Depois dessas mudanças, em todos os cinco países ocorreram as "eleições fundacionais" (sufrágio universal e direto para o pleito presidencial), consideradas por autores como Schneider e Schmitter (2004) como um marco para o início da transição democrática ${ }^{7}$. Essas eleições ocorreram em 1991 em Cabo Verde e em São Tomé e Príncipe, em 1992 em Angola e em 1994 na Guiné-Bissau e em Moçambique. Dessa forma, já na década de 1990, todos os PALOP passaram a ter um sistema multipartidário e a realizar eleições periódicas tanto para o Poder Executivo quanto para o Legislativo. Essas mudanças perduram até a atualidade e demonstram que alguns parâmetros democráticos mínimos são adotados por esses países, mesmo nos considerados como mais autocráticos, tais como Angola e Guiné-Bissau.

Após a análise realizada, foi possível observar o número significativo de similaridades históricas identificadas nas realidades dos PALOP, primordialmente durante o período colonial e o pós-independência. Esse contexto fez com que esse grupo de países atendesse plenamente ao segundo requisito para a sua aplicação ao modelo de análise supracitado.

É importante destacar que, no momento da liberalização, todos os PALOP eram autocracias baseadas em um regime de partido único, pautado em um cenário de restrições de direitos políticos e de liberdades civis. Entretanto, em 2017, aproximadamente 25 após

\footnotetext{
${ }^{7}$ As definições de democratização, liberalização e transição democráticas serão exploradas no Capítulo 1 da presente tese.
} 
o início da democratização, cada país seguiu uma trajetória democrática distinta, conforme será exposto no tópico a seguir.

\section{Resultados diferentes da democratização: casos de sucesso e insucesso}

O terceiro aspecto que se mostrava essencial para a escolha dos casos que serão testados no supracitado modelo se refere à existência de valores distintos no escopo da variável dependente, ou seja, em 2017 os resultados da democracia liberal deveriam ser diferentes nesse conjunto de países. Nesse universo, os PALOP se adequaram mais uma vez, pois, além de permitirem a realização de uma análise tipológica com casos de sucesso e de insucesso democrático, evitando assim o viés de seleção, foram observados nos seus desdobramentos democráticos diferentes gradações. Isso significa que enquanto os países insulares se mostraram democráticos, Moçambique refletiu um estágio intermediário na transição democrática ao mesmo tempo em que Guiné-Bissau e Angola apresentaram-se com um caráter muito mais autocrático.

Esses resultados diferentes na variável dependente foram identificados por meio dos valores expressos pela Freedom House (2017), que classificou Cabo Verde e São Tomé e Príncipe como países "livres" (com valores de 1,0 e 2,0, respectivamente), Moçambique e Guiné-Bissau como "parcialmente livres" (com valores de 4,0 e 5,0, respectivamente, estando Guiné-Bissau em um estágio significativamente mais autocrático do que Moçambique) e Angola, como "não-livre" (com um valor de 6,0). Ressalta-se, nesse ínterim, a conceituação de Cabo Verde como o mais livre dos PALOP, e de Angola, como o menos livre. Esses resultados foram compilados na figura a seguir, permitindo observar de maneira clara a os seus diferentes estágios democráticos, a saber:

Figura 4 - Escala da democracia nos PALOP em 2017 (FREEDOM HOUSE, 2017)

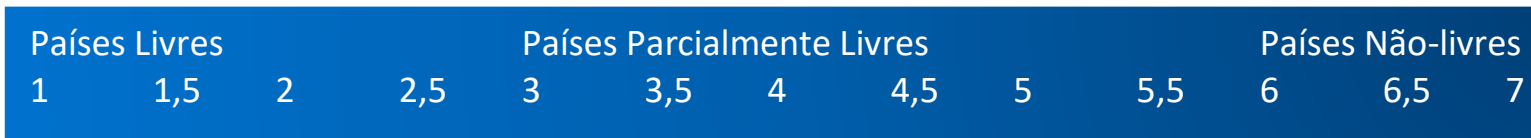

Cabo Verde São Tomé e Príncipe Moçambique Guiné-Bissau Angola 
A seguir, serão analisados os gráficos da Freedom House (2015) que mensuram a democracia de 1995 a 2015. Neles, será possível verificar o sucesso democrático dos PALOP insulares e os avanços e retrocessos da democracia nos PALOP continentais. Destaca-se que, infelizmente, a instituição não disponibilizou informações sobre a evolução da democracia nesse formato para Cabo Verde. O gráfico de São Tomé e Príncipe mostra que, mesmo se apresentando democrático (classificado com o valor 2,0 em 2015), houve uma ligeira redução da sua democracia em 2003, conforme se identifica abaixo:

\section{Gráfico 2 - Gráfico sobre democracia de São Tomé e Príncipe de acordo com a Freedom House (2015)}

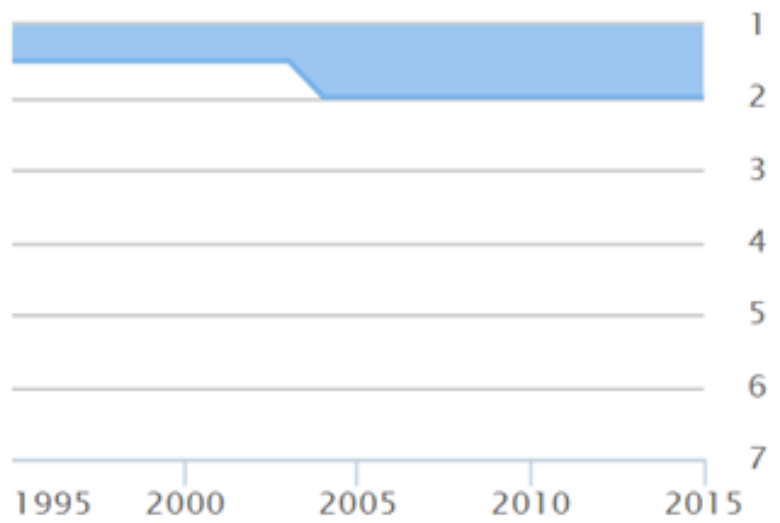

Fonte: FREEDOM HOUSE, 2015, s.p.

Já em Moçambique, durante os 10 anos analisados pela instituição, observa-se uma relativa estabilidade no seu processo de democratização, que apresentou uma melhora por volta de 2007, mas já refletiu um declínio em 2011. Observa-se, nesse gráfico, o caráter intermediário ("parcialmente livre" com o valor 3,5) da democracia moçambicana em 2015, a saber: 


\section{Gráfico 3 - Gráfico sobre democracia de Moçambique de acordo com a} Freedom House (2015)

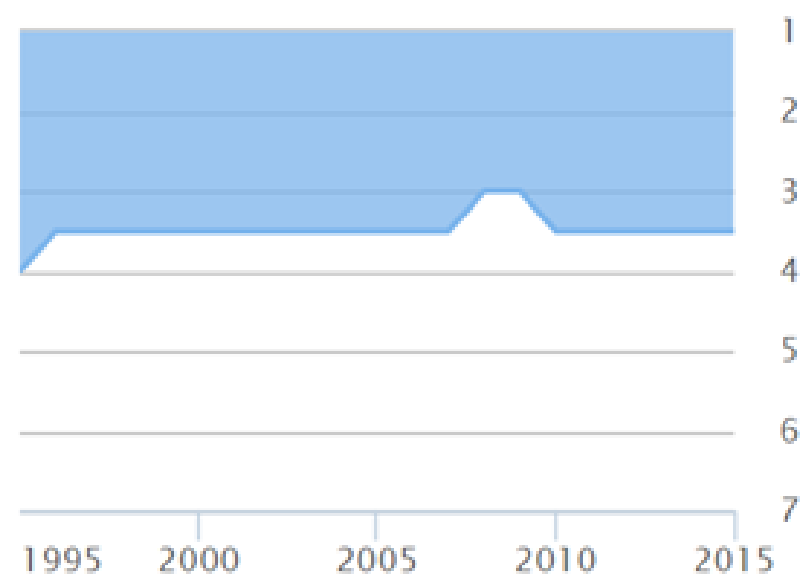

Fonte: FREEDOM HOUSE, 2015, s.p.

Da mesma forma que Moçambique, Guiné-Bissau também é considerada pela Freedom House (2015) como "parcialmente livre". Contudo, a sua classificação é significativamente inferior, apresentando um indicador de valor 5,0. Vale destacar que, com a classificação de 5,5 os países já são denominados como "não-livres". No gráfico a seguir, observa-se que a trajetória democrática guineense foi permeada por muita instabilidade, sofrendo uma queda expressiva em 2012, após a realização de um golpe de Estado perpetrado por alguns militares.

\section{Gráfico 4 - Gráfico sobre democracia da Guiné-Bissau de acordo com a} Freedom House (2015)

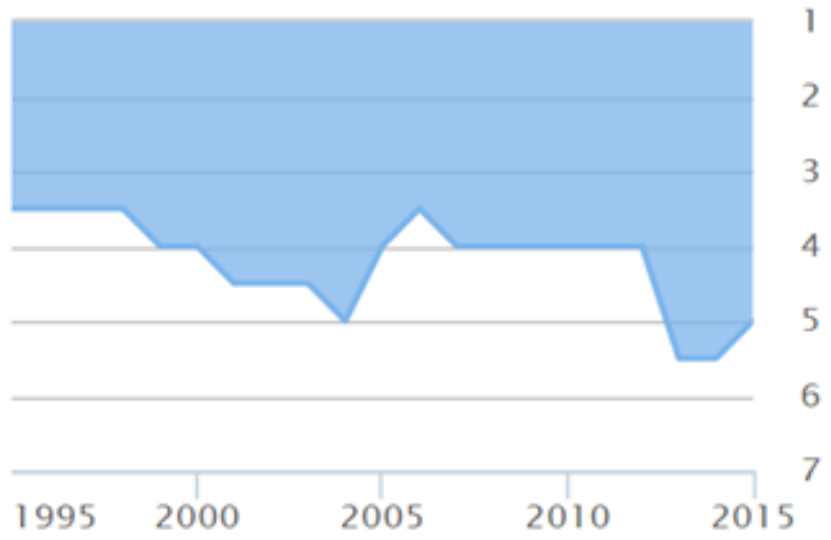

Fonte: FREEDOM HOUSE, 2015, s.p. 
Em Angola, nota-se que de 1995 a 2015, foram observados ganhos democráticos de 1,5 ponto, apesar do país se encontrar classificado como "não-livre". Nesse período, dois momentos marcaram esse aumento da democracia: em 1996 e em 2003, notadamente depois do fim da sua guerra civil, que ocorreu no ano de 2002. Contudo, o status autocrático angolano permanece o mesmo há 12 anos, revelando um processo democrático lento e permeado por avanços pontuais, conforme se observa a seguir:

\section{Gráfico 5 - Gráfico sobre democracia de Angola de acordo com a Freedom House (2015)}

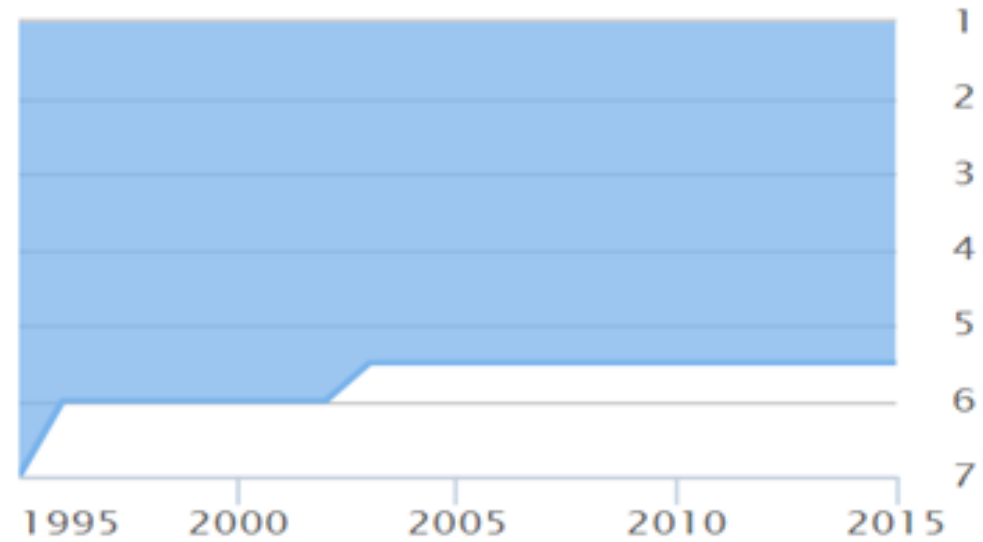

Fonte: FREEDOM HOUSE, 2015, s.p.

Por meio da breve análise realizada utilizando os indicadores da Freedom House, observou-se que cada um dos PALOP trilhou a sua própria trajetória política, construindo a sua democracia de maneira singular. Nesse ínterim, esse grupo de países atendeu a todos os requisitos necessários para que pudessem ser estudados nesta tese, que se pautará na aplicação de uma metodologia comparada influenciada pelo método da "Mais Semelhança", tendo como objetivo testar de maneira fidedigna o modelo supracitado nesta Introdução.

Muekalia (2013) na obra “Angola - A segunda Revolução” afirma que abordar o conturbado período do pós-independência no país se assemelha à 
versões, como partes complementares de um todo, lhes permitiu ter uma ideia aproximada do que era um elefante (MUEKALIA, 2013, p. 11).

Assim como o autor que, no referido livro, compartilha as suas memórias tendo como objetivo realizar uma contribuição específica e delimitada de um cenário histórico extremamente complexo, a pesquisa que se encontra na presente tese exerce uma função semelhante. Conforme citado anteriormente, este trabalho visa a contribuir para a literatura sobre os PALOP ao realizar uma análise comparada considerando o escopo das teorias de democratização para o entendimento da estrutura política desses Estados na pós-bipolaridade. Dessa forma, procura-se analisar e compreender essa parte importante da história contemporânea da África lusófona, ressaltando a sua interface com a implantação da democracia. Nessa investigação doutoral, foi realizado um trabalho cuidadoso para que essa "parte do elefante" fosse bem detalhada e corresponda à realidade factual, resultando em um estudo que, no futuro, possa contribuir para outras pesquisas focalizadas no referido tema.

Após a contextualização dos principais aspectos presentes para a elaboração da tese, tem-se no próximo tópico uma breve exposição sobre a sua estrutura, abordando o conteúdo que se pretende trabalhar em cada um dos seus cinco capítulos.

\section{Estrutura da Tese}

O presente trabalho será estruturado em duas partes, sendo composto pela Introdução, por cinco capítulos e pelas considerações finais. Após a presente Introdução, inicia-se a Parte I, onde encontrar-se-ão os Capítulos 1 e 2. O Capítulo 1 abordará a democracia e as teorias sobre democratização pautadas na liberalização, transição e consolidação democráticas. Nesse espectro, serão analisados os conceitos relativos à democracia eleitoral e à democracia liberal. As Ondas de Democratização nas concepções de Huntington e de McFaul também serão também escrutinizadas, bem como o papel das variáveis internas e externas para os processos de democratização contemporâneos.

O Capítulo 2 será destinado à análise dos aspectos metodológicos mais específicos para a compreensão do método comparado no escopo empírico da tese. Nesse cenário, serão evidenciados a cadeia causal e o desenho de pesquisa adotado, 
explicitando, com base na literatura sobre democratização, a importância que as variáveis independentes escolhidas têm para a compreensão deste estudo.

Já a Parte II englobará os Capítulos 3, 4 e 5, pautando-se em três estudos de caso que analisarão a trajetória democrática dos PALOP em diferentes momentos históricos, sendo eles: a) período colonial, b) período do regime de partido único e c) democratização. Dessa forma, cada período histórico corresponderá a um estudo de caso, que abordará cinco unidades de análise que serão compostas por cada um dos PALOP, a saber: Cabo Verde, São Tomé e Príncipe, Moçambique, Guiné-Bissau e Angola. Nesse contexto, o Capítulo 3 será destinado ao escrutínio do cenário colonial, o Capítulo 4 analisará o período monopartidário e o Capítulo 5, as liberalizações e processos de transição para a democracia dos PALOP depois de 1990. Por fim, as conclusões da tese aglutinarão, em perspectiva comparada, as principais informações expostas nos capítulos anteriores, de modo a verificar a veracidade da hipótese, testando o modelo de análise demonstrado nesta Introdução.

É importante destacar que este trabalho utilizou como bibliografia tanto dados primários quanto dados secundários. No âmbito dos dados primários, tem-se um universo de bases de dados que foi explorado nos âmbitos social, político e econômico, composto pelo V-DEM, Banco Mundial, Fundo Monetário Internacional (FMI), Freedom House, Polity IV, African Elections, Afrobarômetro e Índice Ibrahim de Governança na África (IIAG). Além disso, foram utilizados documentos oficiais, tais como as Constituições Federais de Cabo Verde, São Tomé e Príncipe, Moçambique, Guiné-Bissau e Angola. Já no contexto dos dados secundários, a investigação se pautou nas seguintes fontes: a) artigos científicos de periódicos especializados; b) artigos científicos de revistas nacionais internacionais, c) artigos jornalísticos, d) documentários e c) livros, sendo todo esse material focalizado nos seguintes temas: teorias sobre democratização, metodologia comparada, história dos PALOP, direitos políticos e liberdades civis nos PALOP, crescimento econômico e desenvolvimento social dos PALOP do período colonial até a contemporaneidade, entre outros temas afins.

Por meio da presente Introdução, foi possível compreender o contexto, a estrutura e as principais premissas que fundamentaram a construção desta tese, que se iniciará a seguir abordando, na Parte I, a supracitada revisão de literatura e os principais aspectos metodológicos referentes à elaboração da pesquisa. 


\title{
PARTE I - ASPECTOS TEÓRICOS E METODOLÓGICOS PARA A ELABORAÇÃO DO ESTUDO SOBRE A DEMOCRATIZAÇÃO DOS PALOP NO PÓS-GUERRA FRIA
}

\begin{abstract}
Da mesma maneira como faziam essas vertentes da literatura, meus primeiros estudos sobre as novas democracias basearam-se nas premissas que acabei de mencionar: que existe um claro e consistente corpo de teoria sobre a democracia e que, com ele, é possível "viajar" confortavelmente no assunto. O problema - o meu problema, pelo menos - é que hoje estou convencido de que a primeira premissa é errada e a segunda, por conseguinte, impraticável (O`DONNELL, 1999, p. 665).

...empirical evidence related to democratization in any country is so complex and multi-faceted that no theoretical approach completely captures the complexity and explains it satisfactorily (POTTER, 1997).
\end{abstract}

A primeira parte desta tese será focalizada nas questões teóricas e metodológicas basilares para a formulação deste trabalho, abarcando dois capítulos. No Capítulo 1, observar-se-á uma revisão de literatura sobre democracia e democratização. Já o Capítulo 2 abordará aspectos específicos da Política Comparada, demonstrando tanto a cadeia causal construída para este estudo quanto a explicação do papel de cada variável nela presente, denotando o significado dos seus valores e a literatura que explica os motivos para os quais elas foram escolhidas para fazerem parte da investigação. 


\title{
CAPÍTULO 1 - DEMOCRACIA E COMPONENTES DA DEMOCRATIZAÇÃO: UMA ABORDAGEM TEÓRICA
}

O presente capítulo tem como objetivo apontar na literatura sobre democratização os principais conceitos e referenciais teóricos que serão utilizados na presente tese de doutorado. Dessa forma, ele será dividido e cinco partes principais, que abordarão os seguintes temas: a) definição de democracia; b) as ondas de democratização; c) o debate e as teorias sobre a democratização; d) a liberalização de um regime autocrático, e) as transições democráticas, f) a importância democratização para a ajuda externa e, por fim, a g) consolidação da democracia ${ }^{8}$.

A delimitação dos principais conceitos que serão utilizados na tese é essencial porque permitirá um entendimento holístico sobre as variáveis abordadas na metodologia e, especificadamente, compreender o seu papel no desenho de pesquisa da investigação, que se encontrará exposto no Capítulo seguinte. É importante destacar que, além disso, os debates da literatura de democratização serão fundamentais para a análise e contextualização da liberalização e da transição democrática dos PALOP no pós-Guerra Fria.

\section{Democratização em perspectiva: teorias e debates}

\section{Democracia eleitoral e democracia liberal}

\begin{abstract}
How is that word "democracy" to be interpreted? My idea of it is that the plain, humble, common man, just the ordinary man who keeps a wife and family, who goes off to fight for his country when it is in trouble, goes to the poll at the appropriate time, and puts his cross on the ballot paper showing the candidate he wishes to be elected to Parliament - that he is the foundation of democracy. And it is also essential to this foundation that this man or woman should do this without fear, and without any form of intimidation or victimization. He marks his ballot paper in strict secrecy, and then elected representatives and together decide what government, or even in times of stress, what form of government they wish to have in their country. If that is democracy, I salute it. I espouse it. I would work for it (WINSTON S. CHURCHILL. HOUSE OF COMMONS, 8 DE DEZEMBRO DE 1944).
\end{abstract}

\footnotetext{
${ }^{8}$ É importante destacar que este capítulo teórico foi baseado na supracitada dissertação de Mestrado elaborada pela autora.
} 
A definição de democracia configura-se como um tema de estudo que fomentou uma vasta produção acadêmica ao redor do mundo. Por sua complexidade e singularidade, diversos autores procuraram contribuir à sua maneira para o entendimento da essência que explica e delimita o universo democrático ${ }^{9}$. Nesse contexto, duas nomenclaturas se destacaram e passaram a ser amplamente utilizadas nesse campo de estudos: a democracia eleitoral exposta por Larry Diamond (1996) e a Poliarquia (democracia liberal), apresentada por Robert Dahl (1971).

A “democracia eleitoral" na concepção de Diamond (1996) se concentra na definição de fatores básicos dos direitos políticos de determinado Estado, focalizando-se primordialmente no sufrágio dos seus habitantes por meio da realização de eleições livres, periódicas, justas, multipartidárias, que permitam no escopo a competição por votos, bem como a candidatura de praticamente toda a população adulta. Nessa análise, as liberdades civis não exercem um papel importante para a mensuração da questão democrática, sendo importante destacar o significativo aumento dessas democracias eleitorais no globo no decorrer dos últimos anos (FREEDOM HOUSE, 2015). Já a Freedom House define a democracia eleitoral sob a égide de quatro critérios, a saber:

(1) “A competitive, multiparty political system"; (2) "Universal adult suffrage for all citizens"; (3) "Regularly contested elections conducted in conditions of ballot secrecy, reasonable ballot secrecy, and in the absence of massive voter fraud, and that yield results that are representative of the public will"; (4) and "Significant public access of major political parties to the electorate through the media and through generally open political campaigning". Based on the conceptual and methodic framework of Freedom House, every liberal democracy also is an electoral democracy, but not every electoral democracy qualifies as a liberal democracy (CAMPBELL, 2008, p. 18).

Nesse ínterim, os países que iniciam a sua transição democrática normalmente garantem os direitos políticos antes das liberdades civis. Assim como Diamond (1996), Huntington (1996) também acredita que a democracia eleitoral seja um passo para a conquista da democracia liberal. Para o autor, a democracia liberal engloba fatores

\footnotetext{
${ }^{9}$ Sobre as inúmeras definições de democracia, Campbell (2008) afirma que: "There exists not only one theory, concept or model of democracy, but clearly a pluralism (or plurality) of different theories and models [...] Representatively, we may cite Bühlmann (et al. 2008, p. 5): "There is an abundant literature relating to democracy theory, with countless definitions of what democracy should be and what democracy is." We can add on by referring to Laza Kekic $(2007$, p. 1): "There is no consensus on how to measure democracy, definitions of democracy are contested and there is an ongoing lively debate on the subject" (CAMPBELL, 2008, p. 04).
} 
intimamente conectados às liberdades civis, como a restrição ao Poder Executivo, a presença de um judiciário independente, a proteção de direitos individuais e liberdades de expressão, crença e associação, a proteção do direito das minorias, garantias efetivas contra prisões arbitrárias, e, finalmente, o controle mínimo da mídia pelo governo.

Apesar de não existir uma "receita" para a democracia, a escolha de uma das suas definições é fundamental para estabelecer o dirrecionamento de determinada pesquisa. Neste estudo, a concepção de democracia que será utilizada é a apresentada por Robert Dahl (1971) na obra "Polyarchy", na qual o autor utiliza-se do "procedural mínimo", que expressa uma junção tanto dos direitos políticos quanto das liberdades civis.

Dahl (1971) afirma que a igualdade dos indivíduos é o fator chave para a democracia, em que cada pessoa tem a possibilidade de escolher e expressar as suas preferências frente à sociedade e ao governo por meio de ações individuais ou coletivas. Essas escolhas, por sua vez, devem ser analisadas de forma igualitária dentro do escopo dos trâmites burocráticos, não sofrendo discriminação devido ao seu conteúdo ou causa.10 Dahl (1971) elabora o conceito de "procedural mínimo", que consiste em oito condições principais - garantias institucionais - que caracterizam determinado Estado como democrático. Essas condições são as seguintes:

1) liberdade para formar e se juntar a organizações,

2) liberdade de expressão,

3) direito ao voto,

4) elegilidade para cargos públicos,

5) direito dos líderes políticos de competirem por apoio,

6) fontes alternativas de informação,

10 Para Dahl (1971), a democracia encontra-se intrinsecamente conectada à responsividade do governo às preferências dos cidadãos, que são politicamente iguais. Logo, os indivíduos devem possuir oportunidades plenas de formular suas preferências, exprimi-las e tê-las igualmente consideradas sem qualquer distinção. 
7) eleições livres e justas,

8) as instituições que fazem políticas governamentais.

Destaca-se que essas condições propostas pelo autor serão utilizadas para estudar tanto as liberdades civis quanto os direitos políticos dos PALOP desde o período colonial até a atualidade. Por meio da análise realizada na primeira parte deste Capítulo, foi possível compreender o diálogo existente na literatura contemporânea sobre a definição de democracia, bem como expor e explanar os conceitos de democracia eleitoral e democracia liberal, sendo que este último será amplamente utilizado nos próximos estágios desta tese de doutorado.

\section{As Ondas de Democratização e as transições democráticas no Pós-Guerra Fria}

What democracy is cannot be separated from what democracy should be. A democracy exists only insofar as its ideals and values bring it into being (SARTORI, 1987, p. 7).

A segunda parte deste capítulo é focalizada na análise teórica das ondas de democratização nas concepções de Huntington (1996) e de McFaul (2002). Ele é importante porque permite a contextualização temporal e espacial das transições democráticas dos PALOP, permitindo uma interface hermenêutica desses fenômenos democráticos no cenário emergente da Nova Ordem Mundial.

De acordo com Huntington (1996), uma onda de democratização consiste em um determinado período de tempo no qual a quantidade de democracias ultrapassa de forma expressiva o número de autocracias. Considerando-se essa definição específica, é possível observar que as transições democráticas dos PALOP se encontram dentro do espectro da Terceira Onda de Democratização. Para McFaul (2002), entretanto, uma onda de democratização é definida pelo conjunto de características idiossincráticas que compõem um determinado período de transição para a democracia. Nesse ínterim, a realidade de transição democrática dos PALOP estaria inserida no universo das transições dos países ex-comunistas na década de 1990, integrando o que o autor denomina de Quarta Onda de Transição Democrática. A seguir, serão explicadas detalhadamente essas 
duas abordagens teóricas, bem como o seu papel para a compreensão do trabalho realizado nesta tese.

Nos últimos dois séculos, Huntington (1996) aponta a existência de três ondas de democratização. A primeira delas iniciou-se na década de 1820, por meio da ampliação do sufrágio para uma significativa parcela da população masculina dos Estados Unidos da América. Ela finalizou-se em 1926, tendo como resultado vinte e seis novas democracias. A sua onda reversa (momento no qual mais países te ronam autocráticos do que democráticos) prolongou-se de 1926 a 1942, tendo o seu início marcado em 1922 com a Marcha de Mussolini contra Roma. Os maiores exemplos desta onda foram os golpes militares na Lituânia, Polônia e Letônia, a ascensão de Hilter na Alemanha e o fim da democracia na Tchecoslováquia.

A Segunda Onda de Democratização emergiu depois da Segunda Guerra Mundial, exprimindo o sucesso da democracia na Alemanha Ocidental, Japão, Áustria e Coréia. Esse período foimarcado pela retomada da democracia na Turquia, Brasil, Grécia e Costa Rica. Mesmo tendo transcorrido em um espaço de tempo relativamente pequeno, ela apresentou trinta e seis países democráticos em 1962. A sua onda reversa surgiu na década de 1960, expressa pela insurgência dos regimes militares na América Latina. Iniciada no Peru em 1962, desencadeou-se para o Brasil e Bolívia em 1964, para a Argentina em 1966, para o Equador em 1972, e, finalmente, para o Chile e o Uruguai em 1973 (HUNTINGTON, 1996).

Já a Terceira Onda de Democratização configurou-se como um marco histórico, resultando na adoção do regime democrático por mais da metade dos países do mundo. Seu início ocorreu em Portugal, durante a Revolução dos Cravos (1974), tendo se alastrado rapidamente pelo globo (Europa meridional, América Latina, e o leste, sudeste e sul da Ásia), apresentando como consequência a ascensão de pelo menos trinta nações democráticas entre os anos de 1974 e 1990. Huntington (1996) também ressalta que na década de 1990, o processo de democratização se aprofundou significativamente, impulsionado por eventos como o colapso da União das Repúblicas Socialistas Soviéticas (URSS) e das Europas do Leste e Central, e a emergência do regime democrático na América Central e na África Sub-sahariana - cenário no qual se inserem os países analisados na presente tese (HUNTINGTON, 1996). 
Devido à sua extensão, a Terceira Onda pode ser dividida em distintos momentos. O primeiro deles ocorreu no sul da Europa e da América Meridional entre os anos de 1970 e 1980 . Nesses contextos, a democratização foi impactada primordialmente devido ao papel exercido pelas elites, que por diversos fatores, como a crise econômica, se fragmentaram, resultando em um processo democratizante iminentemente top down (O`DONNELL; SCHMITTER, 1986). Os transitólogos que estudaram esses momentos foram denominados autores da primeira geração da teoria de transição democrática, visto que para este grupo específico, as variáveis domésticas consistiam nos fatores mais importantes para explicar a transformação de um regime autoritário para um democrático (CASTRO SANTOS, 2010a). Uma crítica contundente a esse posicionamento é a de que os países analisados por esses autores eram Estados fortes e consolidados, sendo excluídas do referido espaço amostral os países vulneráveis ou falidos (failed states) (WHITEHEAD, 2005).

Já o segundo momento da Terceira Onda apresentou-se bastante distinto do observado no período anterior. As realidades das transições democráticas dos países excomunistas na década de 1990 delineavam contextos completamente opostos dos padrões obtidos nas décadas de 1970 e 1980. A última década do século XX marcou um período específico, pautado em fatores como: as massas passaram a exercer um papel essencial para a democratização (transições ocorridas por um processo que aglutinou estruturas top down e bottom up), a variável externa representada pelo contágio (snowball effect) se tornou fundamental para explicar os fenômenos democratizantes, o jogo de transição se desdobrou de maneira não-cooperativa e violenta e questões como a unidade e identidade nacional emergiram em um cenário desafiador e novo para os intelectuais (MCFAUL, 2002). Esse complexo cenário fez com que surgisse um novo eixo de pesquisa no âmbito da literatura de democratização. O grupo de acadêmicos que se dedicou a compreender a democracia na égide desse novo arranjo mundial passou a ser denominado autores de segunda geração, e sua característica principal foi a importância dada por eles à variável externa nos processos de transição democrática (CASTRO SANTOS, 2010a). Na figura a seguir, pautando-se nos dados do Polity IV, observa-se a trajetória democrática dos países no mundo desde o século XIX: 
Figura 5 - Democracias no mundo de 1820 a 2012 (TEACHING

COMPARATIVE, 2013)

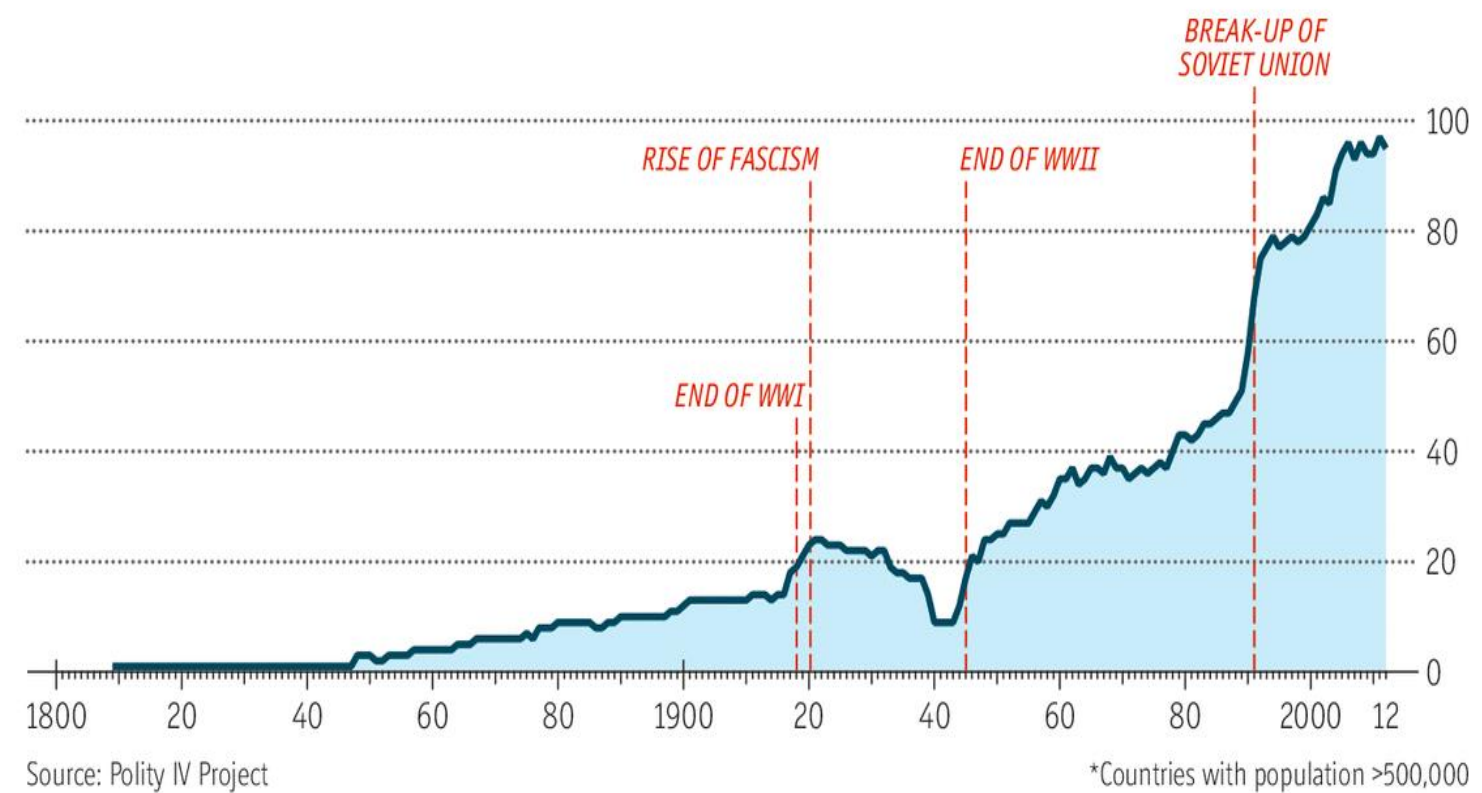

Fonte: TEACHING COMPARATIVE, 2013, s.p.

Conforme apresentado anteriormente, de acordo com a conceituação de Huntington (1996), as transições democráticas dos países da ex-URSS não podem ser compreendidas como o início de uma nova onda democrática, pois estão inseridas no universo da Terceira Onda de Democratização. Entretanto, para McFaul (2002), as transições desencadeadas nos anos de 1990 configuraram o começo de um percurso formativo histórico distinto, representando um novo momento para a literatura de democratização intitulado por ele como a Quarta Onda de Transição Democrática (MCFAUL, 2002). A análise das transições democráticas dos PALOP no pós-Guerra Fria permite a compreensão desses fenômenos dentro do espectro das Ondas de democratização deste autor. Entretanto, é importante apontar que as democratizações da África lusófona apresentam características próprias ainda não evidenciadas de maneira aprofundada nesta literatura específica. Essas características seriam pautadas no fato de que a transição democrática dos PALOP não ocorreu de maneira bottom up, mas foi resultado de uma ação instrumentalizada dos governos nacionais para a inserção internacional (captação de recursos externos) desses países no pós-Guerra Fria. Neste 
aspecto, esta tese também irá contribuir para o entendimento de qual seria o lugar das transições democráticas dos PALOP na Quarta Onda de Transição Democrática.

A análise teórica realizada permitiu compreender a relação entre o tempo e o espaço das transições democráticas dos PALOP nas concepções de Huntington (1996) e de McFaul (2002). Dessa forma, o estudo que será realizado nos próximos capítulos servirá para endossar o universo epistêmico de pesquisa sobre as transições democráticas desse conjunto importante e específico da África Subsaariana. Na tabela a seguir, é possível identificar, de maneira sistematizada, as ondas de democratização expostas por Huntington (1996) e o lugar que as transições para a democracia dos PALOP ocupam: 
Tabela 1 - As Ondas de Democratização (HUNTINGTON, 1996)

\begin{tabular}{|c|c|c|c|}
\hline Onda & Datas & $\begin{array}{l}\text { Características } \\
\text { importantes }\end{array}$ & Paises afetados \\
\hline Primeira Onda & $\begin{array}{l}1828 \text { (sufrágio } \\
\text { universal } \\
\text { masculino) }\end{array}$ & $\begin{array}{l}\text { Substitui } \\
\text { principalmente as } \\
\text { monarquias } \\
\text { absolutistas. A } \\
\text { mais duradoura } \\
\text { das três ondas. }\end{array}$ & $\begin{array}{l}\text { Das } 64 \text { nações } \\
\text { independentes, } \\
29 \text { se tornaram } \\
\text { democráticas na } \\
\text { crista da onda } \\
(45,3 \%) .\end{array}$ \\
\hline $\begin{array}{l}\text { Primeira } \quad \text { Onda } \\
\text { Reversa }\end{array}$ & $\begin{array}{l}1922 \text { (Marcha sobre } \\
\text { Roma) -1942 }\end{array}$ & $\begin{array}{l}\text { Surto de regimes } \\
\text { totalitários no } \\
\text { mundo. }\end{array}$ & $\begin{array}{l}\text { Das } 61 \text { nações } \\
\text { independentes, } \\
12 \text { se tornaram } \\
\text { democráticas } \\
(32,4 \%)\end{array}$ \\
\hline Segunda Onda & $\begin{array}{l}1943 \text { (pós-Segunda } \\
\text { Guerra Mundial) - } \\
1962\end{array}$ & 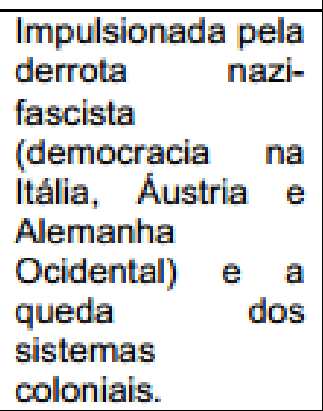 & $\begin{array}{l}36 \text { países } \\
\text { democráticos. }\end{array}$ \\
\hline $\begin{array}{l}\text { Segunda } \\
\text { Reversa }\end{array}$ & $1960-1975$ & \begin{tabular}{lr}
\multicolumn{2}{l}{ Desencadeada } \\
principalmente \\
pelos regimes \\
militares \\
América & Latina \\
$(1960)$. & \\
\end{tabular} & $\begin{array}{l}\text { Das } 122 \text { nações } \\
\text { em } 1973,30 \text { eram } \\
\text { democráticas. }\end{array}$ \\
\hline Terceira Onda & $\begin{array}{l}1974 \text { (Revolução } \\
\text { dos Cravos) - } 1990 \\
\text { (atualidade?) }\end{array}$ & $\begin{array}{l}\text { Pós 1990: } \\
\text { democratizaçăo } \\
\text { mais intensa com } \\
\text { a queda da URSS } \\
\text { e } \\
\text { democratizações } \\
\text { na América } \\
\text { Central e África } \\
\text { subsahariana, sul } \\
\text { e oeste da Ásia. } \\
\text { Em 2011: de } 197 \\
\text { paises (incluindo } \\
\text { o Sudăo do Sul), } \\
66 \text { nações săo } \\
\text { livres, } 72 \text { naçöes } \\
\text { săo parcialmente } \\
\text { livres e } 59 \text { nações } \\
\text { năo săo livres } \\
\text { (FREEDOM } \\
\text { HOUSE, 2012). }\end{array}$ & 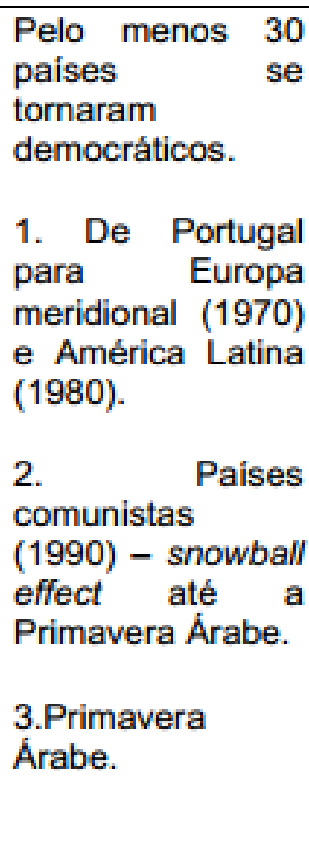 \\
\hline
\end{tabular}

Fonte: QUEIROZ, 2012, p. 20. 


\section{As diferentes fases da democratização: liberalização, transição democrática e consolidação da democracia}

A escolha e definição de conceitos basilares na literatura sobre democratização não constitui uma tarefa fácil para o investigador. Por se tratar de uma literatura relativamente fragmentada, é fundamental apontar cuidadosamente os limites conceituais dos termos utilizados, de modo a alinhar todo o trabalho com as suas respectivas terminologias. Dessa forma, após exemplificar o conceito de democracia que será adotado nesta tese, serão abordados a seguir outros conceitos importantes para a compreensão deste estudo, sendo eles: democratização, liberalização, transição democrática e consolidação para a democracia.

De acordo com Schneider e Schmitter (2004), o processo de democratização apresenta três componentes: a) a liberalização da autocracia; b) a transição democrática e c) consolidação da democracia ${ }^{11}$. Para os autores, as dimensões múltiplas desses três estágios se mostram profundamente conectadas umas às outras, tanto temporalmente quanto espacialmente. Contudo, eles enfatizam alguns dos problemas enfrentados pelos pesquisadores que buscam compreender e construir um novo conhecimento pautado nessa literatura, apontando os limites dos conceitos e dos indicadores disponíveis para analisar esses procedimentos:

Neither the process of liberalization nor that of consolidation has been consistently conceptualized, much less operationalized, in the literature on democratization. They have been used quite often (and controversially), but almost invariably in an erratic fashion - even by the same author in the same work. Moreover, the empirical indicator that has been most frequently employed in quantitative analyses, the Freedom House Index, is seriously deficient and distorted, especially when used to measure variation across regions or over time in the same country (SCHNEIDER; SCHMITTER, 2004, P. 60).

\footnotetext{
${ }^{11}$ A divisão de democratização em três componentes, conforme abordado por Schneider e Schmitter (2004), será a base para a revisão de literatura deste trabalho nos âmbitos da liberalização, transição democrática e consolidação para a democracia. Essa estrutura foi mencionada no artigo "Liberalization, Transition and Consolidation: Measuring the Components of Democratization", no qual os autores analisam esses diferentes momentos da democratização em 30 países que realizaram as suas transições democráticas em inúmeras partes do mundo, a saber: sul da Europa, América do Sul, Europa Central e do Oriental, América Central, Oriente Médio e Norte da África. Nota-se que a África subsaariana não foi representada nesse estudo. Na literatura clássica sobre democratização, as transições da África subsaariana são escassamente abordadas.
} 


\section{Primeira fase da democratização: liberalização política}

Para Schneider e Schmitter (2004), a liberalização é um termo muito utilizado e bem aceito nos discursos acadêmico e político. Apesar das suas diferentes perspectivas, os autores abarcam somente a sua dimensão política, sendo essa abordagem o foco da liberalização adotado na presente tese. Para medir a liberalização da autocracia, eles sugerem sete indicadores, sendo eles:

a) O regime realiza concessões públicas significativas no nível dos direitos humanos;

b) O regime não tem (ou quase não tem) prisioneiros políticos;

c) O regime demonstra crescente tolerância pela dissidência/ oposição pública de grupos sociais ou de organizações formais/ informais (por exemplo: partidos, associações ou movimentos);

d) Existe mais de um partido político independente legalmente reconhecido;

e) Existe pelo menos um partido de oposição reconhecido no Parlamento ou na Assembleia Constituinte;

f) Existem sindicatos ou associações profissionais que não são controlados por agências estatais ou partidos governantes;

g) Existe uma imprensa independente e acesso a fontes alternativas de informação que são toleradas pelo governo.

No contexto desta investigação, alguns desses indicadores serão utilizados para demonstrar a liberalização política ocorrida nos PALOP após 1990.

Przeworski (1992) afirma que o primeiro estágio para a democracia é a liberalização, definida como a trajetória na qual eles elites controlam a abertura do regime. Esse processo também pode ser denominado de distensão, renovação ou reconstrução (perestroika), tendo as suas origens tanto nas pressões das elites quanto nas demandas da população, constituindo-se como um momento de instabilidades que revela os limites das reformas democráticas. Na concepção do autor, todas as transições democráticas apresentam um caráter de negociação, seja entre os representantes do regime antigo ou entre as forças favoráveis à instauração da democracia. Destarte, a transição é finalizada quando há a possibilidade de alterância de poder no governo, na alternância dos partidos políticos e no controle efetivo dos civis sobre os militares. 
Donald Share e Scott Mainwaring (1986) também afirmam que é o próprio regime que decide iniciar a liberalização, mas que o controle de sua gradação é relativo. O cenário que se observa nas liberalizações dos PALOP pauta-se no fato de que elas foram iniciadas pelas elites políticas que se encontravam no poder, de uma maneira negociada e, notadamente, controlada.

Ao estudar os processos de democratização, Guillhermo O’Donnell (1992), demonstram a complexidade imbuída na mudança de um governo autoritário para um democrático, já que esse processo se apresenta longevo e conectado a diversos fatores que exercem uma função essencial para o sucesso ou fracasso da transição para a democracia. Nesse ínterim, o autor aponta as duas fases basilares da democratização: a primera delas consiste no período transição democrática, e a segunda, no momento da consolidação da democracia. Esses dois períodos serão analisados a seguir, evidenciando o fato de que essas fases podem sobrepor-se e, até mesmo, ocorrer ao mesmo tempo.

\section{Segunda fase da democratização: transição democrática}

A terceira parte deste Capítulo propiciará o entendimento das transições democráticas, das suas tipologias e dos fatores domésticos e externos que as fomentam. A compreensão desse aporte teórico é essencial para identificar a dinâmica transicional que cada um dos PALOP perpassou após o colapso soviético.

O expressivo surgimento de novas democracias após a Terceira Onda de Democratização fez com que aumentasse a quantidade de pesquisas direcionadas para a análise das transições democráticas na cena global contemporânea. Guillermo O’Donnell e Philippe Schmitter (1986) definem os períodos de transição democrática como o intervalo entre um regime político autoritário e outro democrático. Contudo, enfatizam que a transição do autoritarismo para outro tipo de regime não necessariamente resulta na democracia. Já Linz e Stepan (1996) descrevem as transições democráticas como o processo de transformação institucional de um regime autoritário para um democrático ${ }^{12}$.

\footnotetext{
12 Para Stradiotto e Guo (2010), "democratic transition is defined as a political process of movement aimed at establishing a democratic political system, initiated either from above or below or a combination of both, promoting democratic values and goals, tolerating opposition, allowing bargaining and compromise among different political forces for the resolution of social conflicts, institutionalizing the pluralist structures and procedures by which different political forces are allowed to compete over the power, regularizing transfer
} 
Wacziarg (2013) classifica a transição democrática como o processo no qual os Estados encontram-se em um estágio idiossincrático, conforme se observa no excerto:

[...] moving from autocratic regimes with low popular participation in political decision-making and weak constraints on the exercise of executive power to more democratic regimes with broader political participation and greater limits on the exercise of political power (WACZIARG, 2013, p. 141).

Muitas das democratizações da Terceira Onda não se completaram com sucesso e apresentaram um percurso distante da instauração da almejada democracia liberal $(G U O, 1999)^{13}$. A multiplicidade e dinâmica desses fenômenos fez com que inúmeras perspectivas teóricas surgissem para explicá-los. Sem conseguirem formar um conjunto teórico coeso, diferentes abordagens diferem entre si em maior ou menor intensidade, formando um universo analítico heterogêneo e plural, conforme se identifica na passagem a seguir:

Different theoretical approaches to transition theory have provided various analytical frameworks for a comparative study of regime transition across regions, and identified factors or variables to explain outcomes of particular transformations that have occurred in different countries under different circumstances. However, "theoretical approaches to democratic transition have not presented any coherent or even elaborate body of work". Transition theory has in fact tended to "diverge" between different schools of thought (GUO, 1999, p. 134).

Schneider e Schmitter (2004) afirmam que o final da transição democrática ocorre com a presença de dois fenômenos principais, a saber: a) realização das primeiras eleições presidenciais ("founding elections") e b) formulação e ratificação de uma nova Constituição ou de mudanças constitucionais (SCHNEIDER; SCHMITTER, 2004). Esses dois componentes foram observados nos cinco PALOP, o que permite assumir que todos eles concluíram os seus processos de transição democrática. Contudo, os resultados dessas transições foram distintos para cada um desses países, com alguns se tornando democráticos enquanto outros permaneceram autocráticos ${ }^{14}$. Visando a mensurar a transição democrática, os referidos autores construíram oito indicadores que demonstram

of power, and engaging in the fundamental transformation of political structure. (STRADIOTTO; GUO, 2010, p. 10).

${ }^{13}$ Nesse universo, tem-se como exemplo os PALOP continentais, que ainda não conseguiram finalizar a sua transição democrática com êxito.

${ }^{14}$ A dinâmica desses cenários será explorada de maneira mais aprofundada no Capítulo 5. 
aspectos importantes que devem ser alcançados pelos países que estão realizando a sua transição para a democracia, sendo eles:

a) Existência de negociações públicas entre movimentos sociais/políticos de oposição e o regime em vigor;

b) Existência de conflitos abertos dentro do aparato administrativo do Estado sobre políticas públicas e o seu reconhecimento pelo governo;

c) Introdução de mudanças formais legais que tem como objetivo limitar o uso arbitrário de poder pelo regime;

d) Introdução de mudanças constitucionais ou legais que eliminam o papel de "non-accountable powers" de grupos de veto;

e) Uma constituição que tenha sido redigida e ratificada que garanta igualdade de direitos políticos e de liberdades civis a todos os cidadãos;

f) Realização de "founding elections";

g) As "founding elections" devem ser livres e justas e

h) Os resultados das "founding elections" devem ser amplamente aceitos.

Após a análise sobre a definição de transição democrática e os fatores que marcam o seu início, serão demonstrados no próximo tópico os diferentes tipos de transição democrática.

\subsection{Tipos de transição democrática}

Donald Share e Scott Mainwaring (1986) dividem as transições democráticas em três grupos: transição após a queda ou colapso do regime; transição por meio da liberalização e transição pela negociação (transição pela transação). Ao analisarem os casos de transição democrática "por negociação" nos casos do Brasil e da Espanha, afirmam que esses processos se encontram intimamente conectados ao regime autoritário anterior. Essa estrutura de transição democrática foi observada no contexto dos cinco PALOP, nos quais o regime autoritário foi o responsável pelas mudanças políticas que foram implementadas durante a democratização.

O’Donnell e Schmitter (1986) classificam a transição democrática como um momento no qual "as regras do jogo" ainda estão incertas, os conflitos entre os atores são latentes e o cenário observado é repleto de vulnerabilidades em relação às novas leis 
fixadas ${ }^{15}$. Para eles, as transições têm a sua gênese no próprio sistema, por meio do fracionamento das elites que estão no poder. Nesse ínterim, a primeira mudança significativa consiste na mudança do regime autocrático em direção à ampliação do aporte de direitos e garantias individuais e coletivas. As motivações para a transição democrática podem ser por meio da derrota militar, da ocupação por uma potência estrangeira ou por pressões externas. É no âmbito das pressões externas (pautada no soft power advindo das potências Ocidentais), que se insere o contexto das democratizações dos PALOP.

No universo analítico proposto pelos autores, a democratização ocorre por meio da assinatura de pactos, da convocação de eleições e da aplicação dos conceitos de cidadania às instituições. Ao definirem as transições pactuadas, apresentam esses processos como fenômenos como mais viáveis, pacíficos e pouco conflituosos. Dentro desse modelo particular de transição, as variáveis domésticas são importantes e quatro atores exercem um papel primordial nesses pactos, sendo o bloco dos autoritários composto pelos linha-dura (hardliners) e os reformistas (que podem ou não ser liberais), e a oposição, integrada pelos moderados e os radicais (O’DONNELL; SCHMITTER, 1986). Uma das considerações basilares apontadas é a premissa de que as transições democráticas possuem duração indeterminada. Isso é observado claramente nos processos transicionais de Angola, Moçambique e Guiné-Bissau, visto que nesses países ainda não se sabe qual é momento exato da sua trajetória democrática, nem o resultado que esse processo terá quando chegar ao seu fim.

A transição pela queda ou colapso do regime é a mais recorrente, sendo expressa pela deterioração do controle das elites autoritárias e a sua consequente retirada do poder. Esse processo pode ser impulsionado tanto por uma crise doméstica (expressa também na perda de legitimidade) quanto por forças externas. Esse tipo de democratização transforma o aparato institucional do Estado e rompe com o autoritarismo. Já a transição pela liberalização apresenta um caráter intermediário ao elucidar um cenário de

\footnotetext{
${ }^{15}$ QUEIROZ (2012) cita o processo de transição abordado pelos autores como: "Uma das considerações mais importantes apontadas por O`Donnell e Schmitter (1986) reside na percepção de que as transições democráticas têm duração indeterminada. Aqueles autores propõem a metáfora do jogo de xadrez de níveis múltiplos para ilustrar tal incerteza. O processo político seria como um jogo de xadrez no qual existem infinitas possibilidades de permutações e combinações resultantes das habilidades de cada jogador, em um contexto no qual os vários jogadores não sabem - enquanto jogam - os resultados que serão obtidos. $\mathrm{O}$ jogo político aconteceria de acordo com as regras que são modificadas no seu transcorrer, onde os jogadores se comprometem, gradualmente, a realizar uma partida mais decorosa e leal de acordo com o novo escopo normativo que eles mesmos elaboram ao longo do tempo" (QUEIROZ, 2012, p. 32).
} 
articulação interna reduzida, composto por elites autoritárias que tentam evitar o colapso do governo ao limitar a maneira e o período no qual a transição ocorrerá. Nesse contexto, as elites autoritárias selam acordos com a oposição e voluntariamente se destituem do poder, perdendo o controle sobre o processo transicional após as primeiras eleições. Já a transição pela transação (transição pela negociação) é a mais pacífica de todas. Nela, observa-se o significativo controle das elites na trajetória democratização, visto que este grupo inicia a liberalização e delibera quanto às pricipais diretrizes do percurso formativo até a democracia. Esta é considerada pelos acadêmicos como a abordagem mais complexa, tendo em vista que as elites autoritárias controlam o processo de transição e participam em alguma medida do novo regime (SHARE; MAINWARING, 1986). Conforme será explicitado nos capítulos a seguir, acredita-se que as transições dos PALOP ocorreram por meio da negociação.

\section{O debate sobre o impacto das variáveis internas e externas nos processos de transição para a democracia}

Enquanto alguns acadêmicos se focalizaram nas causas da mudança de regime, outros enfatizaram os pré-requisitos para a democratização (GUO, 1999). Huntington (1997) expõe um variado conjunto de fatores variados (tanto pré-requisitos quanto causas) que podem explicar o sucesso da democracia, tais como a intervenção externa pelo uso da força. É interessante notar que a intervenção externa sem o uso da força (exemplificada pela ajuda internacional) não se encontra descrita nessa lista, que abarca as seguintes características:

- Alto nível de desenvolvimento econômico;

- Distribuição de renda e/ou de riqueza relativamente igualitária(s);

- Economia de mercado;

- Existência de uma aristocracia feudal em algum ponto na história da sociedade;

- Ausência do feudalismo; 
- Existência de uma burguesia forte;

- Existência de uma classe média forte;

- Altos níveis de alfabetização e educação;

- Uma cultura mais instrumental do que consumatória;

- Protestantismo;

- Pluralismo social e grupos intermediários fortes;

- Desenvolvimento de contestação política antes da expansão da participação política;

- Estruturas de autoridade democrática dentro dos grupos sociais, particularmente aqueles conectados à política;

- Baixos níveis de violência civil;

- Baixos níveis de polarização política e extremismo;

- Líderes políticos compromissados com a democracia;

- Experiência como uma colônia britânica;

- Tradição de tolerância e compromisso;

- Ocupação por um poder estrangeiro pró-democrático;

- Desejo das elites de emular nações democráticas;

- Tradição de respeito pela lei e direitos individuais;

- Homogeneidade étnica, religiosa e racial;

- Heterogeneidade étnica, religiosa e racial; 
- Consenso dos valores políticos e sociais;

- Ausência de consenso dos valores políticos e sociais.

Na análise Huntington (1991), é interessante destacar que um país que não contém as condições internas necessárias para a efetividade da democracia, provavelmente não conseguirá consolidá-la pautando-se apenas no contexto externo favorável ${ }^{16}$. $\mathrm{O}$ autor também argumenta que os fatores mais importantes para a transição democrática são o desenvolvimento econômico e a vontade política das elites.

A literatura clássica sobre transição democrática oferece uma análise relativamente limitada sobre o papel da ajuda externa para a democratização, e do mesmo modo, sobre a importância da democracia para a ajuda externa. Esse tema será abordado na próxima parte deste capítulo, sendo os parágrafos a seguir destinados a compreender a dinâmica da transição no espectro das abordagens teóricas dos autores de primeira e segunda geração da literatura de democratização.

Conforme mencionado anteriormente, os autores da primeira geração da teoria de democratização consideram as variáveis internas como as mais importantes para explicar a trajetória da transição democrática (CASTRO SANTOS, 2010a). Para grande parte desses estudiosos, alguns fatores domésticos são considerados recorrentes para descrever a transição, a saber: o papel das elites se configura como fundamental para o processo de mudança de regime, as negociações ocorrem de maneira cooperativa e pacífica, a participação popular é reduzida e os pactos se mostram importantes e revelam a predominância do jogo de transição.

Rustow (1999) descreve a heterogeneidade presente nas democratizações, fornecendo significativa relevância à junção dos fatores políticos às questões econômicas e sociais. Para o autor, o caminho para a democracia envolve a participação de inúmeros grupos na sociedade, constituindo-se como fenômenos repletos de singularidades, inconstâncias, dinamicidade, conflitos pelo poder e embates civis. Logo, acredita que a

\footnotetext{
${ }^{16}$ Esse aspecto é fundamental porque corrobora com a hipótese da tese, pautada no fato de que apesar das pressões internacionais, questões domésticas exemplificadas pela estabilidade social, política e econômica, explicam o sucesso ou insucesso da transição democrática nos PALOP.
} 
transição democrática perpassa quatro eixos principais: consciência nacional (condições do cenário doméstico); fase preparatória (embate político); fase de decisão (disputas políticas e instauração de consenso entre as diferentes partes); e, finalmente, fase de habituação com o processo democrático.

Após a análise das principais teorias abordada pelos autores da primeira geração da literatura de democratização, discutir-se-ão brevemente as perspectivas adotadas pels autores da segunda geração, que postulam que as variáveis externas podem exercer um papel fundamental nas transições democráticas (CASTRO SANTOS, 2010a). De acordo com Castro Santos (2010b), a intervenção externa pode se desdobrar de diversas maneiras, tais como sanções, cooperação tecnológica, investimentos em determinados setores e, nos casos mais extremos, a ocupação pelo uso da força. Entre todas essas variáveis, esse estudo se focalizará na ajuda internacional, tema que será abordado na próxima parte desse capítulo.

$\mathrm{Na}$ figura a seguir, é possível observar a sistematização das teorias de democratização propostas por Lawson (2006). Entre as seis macro-teorias apontadas, este estudo, sem desconsiderar o papel das variáveis domésticas, se focalizará nas influências externas, demonstradas pela pressão estrangeira por meio da intervenção indireta, exemplificada nos moldes da ajuda internacional. 
Tabela 2 - Síntese das Teorias de Transição Democrática (LAWSON, 2006)

\begin{tabular}{|c|c|c|c|}
\hline Teoria & Variantes & Defensores & $\begin{array}{l}\text { Avaliação } \\
\text { empírica }\end{array}$ \\
\hline $\begin{array}{l}\text { 1. Clivagens } \\
\text { Sociais }\end{array}$ & $\begin{array}{l}\text { 1a. Estrutura de } \\
\text { classe. } \\
\text { 1b. } \\
\text { Homogeneidade } \\
\text { étnica. } \\
\text { 1c. Clivagens } \\
\text { transversais. }\end{array}$ & $\begin{array}{l}\text { Atristóteles, Dahl, } \\
\text { Lijphart, etc. }\end{array}$ & $\begin{array}{l}\text { Misturada com a } \\
\text { economia, forte } \\
\text { na etnicidade. }\end{array}$ \\
\hline $\begin{array}{l}\text { 2. Nivel de } \\
\text { desenvolvime } \\
\text { nto }\end{array}$ & $\begin{array}{l}\text { 2a. Educação, } \\
\text { tolerâncias, etc. } \\
\text { 2b. } \\
\text { Especialização, } \\
\text { cross-currents. } \\
\text { 2c. Urbanização, } \\
\text { mobilização. } \\
\text { 2d. Comunicação, } \\
\text { mobilização. } \\
\text { [2e. Padrões de } \\
\text { desenvolvimento]. }\end{array}$ & $\begin{array}{l}\text { Lipset, Diamond, } \\
\text { Pzrzeworski, etc. }\end{array}$ & $\begin{array}{l}\text { Grande apoio; } \\
\text { mecanismos } \\
\text { menos claros e } \\
\text { muitas ressalvas. }\end{array}$ \\
\hline 3. Cultura & $\begin{array}{l}\text { 3a. Valores das } \\
\text { massas } \\
\text { (confiança, etc.). } \\
\text { 3b. Sociedade } \\
\text { civil e } \\
\text { associações. } \\
\text { 3c. Valores das } \\
\text { elites. }\end{array}$ & $\begin{array}{l}\text { Tocqueville, } \\
\text { Almond e Verba, } \\
\text { Putnam, } \\
\text { Inglehart. }\end{array}$ & $\begin{array}{l}\text { Misturadas } \\
\text { (embora em voga } \\
\text { atualmente). }\end{array}$ \\
\hline 4. Instituições & $\begin{array}{l}\text { 4a. } \\
\text { Presidencialismo. } \\
\text { 4b. Regras } \\
\text { eleitorais. }\end{array}$ & $\begin{array}{l}\text { Hume, Linz, } \\
\text { Valenzuela, etc. }\end{array}$ & $\begin{array}{l}\text { Misturada; apoio } \\
\text { para efeitos de } \\
\text { interação. }\end{array}$ \\
\hline 5. Líderes & $\begin{array}{l}\text { 5a. Socialização } \\
\text { e seleção. } \\
\text { 5b. "Grand } \\
\text { gestures". }\end{array}$ & $\begin{array}{l}\text { Maquiavel, } \\
\text { Schmitter e } \\
\text { O'Donnell, etc. }\end{array}$ & $\begin{array}{l}\text { Misturada; apoio } \\
\text { em tempos de } \\
\text { crise. }\end{array}$ \\
\hline $\begin{array}{l}\text { [6. Influências } \\
\text { externas] }\end{array}$ & $\begin{array}{l}\text { 6a. Diretas } \\
\text { (exemplo: } \\
\text { ocupação). } \\
\text { 6b. Indiretas } \\
\text { (exemplo: } \\
\text { difusão). }\end{array}$ & $\begin{array}{l}\text { Huntington, } \\
\text { USAIDS, etc. }\end{array}$ & $\begin{array}{l}\text { Forte para direta, } \\
\text { misturada para } \\
\text { externa. }\end{array}$ \\
\hline
\end{tabular}

Fonte: QUEIROZ, 2012, p. 47.

Após a explanação dos cenários envolvendo as distintas teorias sobre democratização, é importante mencionar novamente o estudo de Guo (1999), no qual ele sugere que é necessária a aglutinação de diferentes abordagens teóricas para ampliar o 
alcance explicativo da causalidade das variáveis causais, conforme se observa no excerto a seguir:

[...] researchers have to integrate the key elements of competing theories of democratic transition into a more comprehensive analytical framework by which both the short - and long-term casual variables can be situated together in a logic of explanation (GUO, 1999, p. 145).

\section{Transição democrática e ajuda internacional: diálogos e interconexões}

Esta parte do Capítulo 1 se direciona para a análise do impacto da democratização para a ajuda internacional e vice-versa. Ela é importante porque verifica na literatura a relação ainda pouco estudada que existe entre essas duas variáveis. A sistematização teórica das diferentes abordagens que conectam a transição democrática e a ajuda internacional é basilar para o entendimento da recente dinâmica política dos PALOP e o recebimento de ajuda externa de cada um dos países desde a década de 1990. O diálogo sobre as diferentes abordagens sobre o tema será retratado, destacando-se que o posicionamento adotado para o presente estudo será o da literatura mais tradicional e ortodoxa, utilizada pela maioria dos acadêmicos.

A transição democrática é importante para a prospecção de ajuda externa porque os países que melhor se encaixam às "regras do jogo" conseguem se estabelecer como parceiros das grandes potências e angariam uma quantidade maior de recursos internacionais. Os fatores que explicam a construção desse argumento são inúmeros, e variados também são os estudos que tentam descontruir essa corrente teórica. Pautandose no diálogo que ainda se encontra em construção, alguns dos principais estudos que abordam essa temática serão elucidados a seguir.

Kapfer, Nilsen e Nelson (2007) afirmam que, para Jensen, a democratização ajuda a atrair investimentos externos diretos. Entretanto, demonstram que para Li e Resnick o caminho para a democracia exerce impactos positivos e negativos na captação desses investimentos. Para aqueles autores, a democratização é importante porque exprime como axioma o fato de que a ajuda internacional é mais efetiva em países democráticos, onde a demanda por bens públicos e serviços podem influenciar o processo decisório do governo (KAPFER; NIELSEN; NIELSON, 2007, p. 04). Nessa perspectiva, observa-se que a democracia impulsiona o recebimento de ajuda externa, ao mesmo 
tempo em que a ajuda externa, quando utilizada para o fortalecimento da democracia, gera o fortalecimento da democratização. Esse círculo virtuoso continua até que o país receptor possua a sua democracia estável, bem como um aumento no seu grau de desenvolvimento econômico e social. Para os países que não possuem uma variedade de recursos naturais e uma importância estratégica, as recompensas recebidas por cumprirem as exigências democráticas são normalmente expressivas. Essa realidade teórica será observada detalhadamente no caso dos PALOP, que apesar das suas singularidades, se encaixam de maneira geral no modelo desta teoria.

Assim como se observa com o papel exercido pela democracia no fomento da ajuda externa, a importância da captação de ajuda externa para a transição democrática é um tema que, além de relativamente pouco estudado, não encontra um consenso na literatura ${ }^{17}$. Enquanto alguns acadêmicos postulam que a ajuda externa fomenta a democracia, outros afirmam que ela, em muitos casos, fortalece os governos autoritários. Focalizada nesse universo de paradoxos e consonâncias, essa parte da revisão de literatura visa a demonstrar que, assim como os estudos mais recentes evidenciam, a ajuda externa exerce um significativo impacto para a democratização ${ }^{18}$, principalmente se os recursos internacionais forem aplicados com condicionalidades e incentivos seletivos que fomentem a instauração da democracia.

Em 2004, o artigo de Stephen Knack intitulado "Does Foreign Aid Promote Democracy?" foi marcante para os estudos sobre transição democrática e ajuda externa. Ao analisar inúmeros países de 1975 a 2000, ele percebeu que não existe uma relação direta entre a ajuda externa e democracia, conforme ele afirma no excerto a seguir:

\footnotetext{
${ }^{17}$ Resnick (2012) acredita que grande parte das disparidades existentes nesta literatura específica resulta no fato de que não há uma separação específica entre os diferentes tipos de ajuda internacional. Com base no argumento do autor, infere-se, por exemplo, que os efeitos da ajuda internacional direcionada primordialmente para o fomento da democracia podem ser distintos da ajuda externa focalizada no desenvolvimento econômico. Considerando que existe uma diferenciação entre os tipos de ajuda externa, o presente trabalho analisa a ajuda externa como um todo, e destaca em contextos específicos tipos singulares de ajuda externa. Dietrich e Wright (2014), ao estudarem a relação entre democratização e ajuda externa na África após a década de 1990, apontaram os relativamente diferentes resultados obtidos entre categorias distintas de ajuda internacional: "economic aid increases the likelihood of transition to multiparty politics, while democracy aid furthers democratic consolidation by reducing the incidence of multiparty failure and electoral misconduct" (DIETRICH; WRIGHT, 2014, p. 01).

${ }^{18}$ Conforme Dietrich e Wright (2014 argumentam: "In the 1990s and 2000s, donors contributed hundreds of billions of dollars of aid worldwide, with the largest proportion flowing to sub-Saharan Africa. Goldsmith (2001) and Dunning (2004) show that foreign aid positively influences democracy in recipient countries, yet neither study explores the causal mechanisms linking aid and democratic change" (DIETRICH; WRIGHT, 2014, p. 02).
} 
Using several alternative democracy indexes and measures of aid intensity, no evidence is found that aid promotes democracy. This evidence does not necessarily imply that no democracy-promoting programs work as intended. But those successful programs appear to be either too few and far between for their effects to be detectable in the aggregated data, or are compensated by other effects of aid that tend to undermine democratic development. (KNACK, 2004, p. 02).

O autor observou que os países que recebiam mais ajuda externa não necessariamente se tornavam mais democráticos, assim como os países que recebiam menos ajuda externa não necessariamente se tornavam mais autoritários. Esse estudo, baseado em dados empíricos e fidedignos, serviu para questionar a veracidade da premissa amplamente presente na literatura pautada no fato de que a ajuda externa desempenha um importante papel no desenvolvimento da democracia. Após esse trabalho, inúmeros autores iniciaram variadas pesquisas utilizando metodologias distintas, com o objetivo de verificar qual aporte teórico era o mais adequado: o de Knack ou o recorrente no escopo da maioria dos acadêmicos.

Nesse espectro, a presente tese contribui para a literatura de democratização apontando que, no caso dos PALOP, é possível observar uma correlação e uma causalidade entre ajuda externa e a democracia, sugerindo que a abordagem de Knack (2004) não se mostra apropriada para explicar o papel da variável externa no escopo das transições democráticas desse conjunto específico de países.

Doyle (2011) afirma que a democracia é melhor promovida de forma pacífica, através de incentivos, assistência e ações indiretas tais como tratados, investimentos e ajuda externa. Essa perspectiva é observada no seguinte excerto:

Democracy is best promoted peacefully. It spreads by good example, by incentives and assistance. Promoting democracy is done best when it is done indirectly through trade, investment, and foreign aid. All these can help develop and diversify societies, and diversified, growing societies tend, over the long run, to demand responsive governance. (DOYLE, 2011, p. 01)

Autores como Kersting e Kilby (2014) concordam com Doyle (2011) e apontam que a ajuda externa se pauta na promoção de democracia em contextos nos quais o Estado beneficiário não apresenta um papel estratégico para o país doador, conforme se observa 
a seguir. O pouco progresso da transição democrática em Angola (país rico em petróleo e diamantes) pode ser explicado parcialmente por meio da afirmação:

We find that some donors ("unconditional donors") always consider democracy when allocating aid, while other donors ("conditional donors") disregard democracy when the recipient country is strategically important. That is, for these conditional donors strategic considerations can override governance issues. For unconditional donors and for countries that are not considered to be strategically important, donor threats to withhold aid if democratization does not occur are credible and should have an impact. However, for conditional donors interacting with strategically important countries, such threats are hollow and should have no impact.

Our short run findings strongly support this mechanism. Countries that are not strategically important or that receive more aid from unconditional donors make significantly more progress toward democracy than countries that are strategically important and receive more aid from conditional donors. (KERSTING; KILBY, 2014, p. 01)

Por meio da análise realizada, observou-se que, embora existam divergências nas teorias que abordam democratização e ajuda externa, a maioria dos estudos contemporâneos endossa a abordagem mais tradicional, pautada no fato de que a democracia é importante para fundamentar a ajuda externa, assim como a ajuda externa é importante para a construção da democracia.

\section{Terceira fase da democratização: consolidação democrática}

The essence of democracy is the habit of dissension and conciliation over ever-changing issues and amidst everchanging alignments (RUSTOW, 1999, p. 24).

Após compreender o universo da transição democrática e a sua relação com a ajuda externa, a última parte deste capítulo será direcionada para o estudo da consolidação da democracia, fenômeno que O’Donnel e Schmitter (1986) chamaram de "a segunda transição democrática". Assim como os outros processos intrísecos à literatura de democratização, a definição do conceito de consolidação democrática não é delimitada e específica. A consolidação democrática caracteriza-se como um período difícil de ser determinado de maneira exata, pois engloba um conjunto de fatores que refletem a 
internalização dos valores e dos princípios democráticos. Esse cenário de incertezas é descrito na seguinte afirmação:

The nice thing with the term "democratic consolidation" (DC) is its seemingly infinite patience and malleability. It is a term that contains few semantic constraints, and in the vast field of consolidation studies, we can use it the very way we like and still uphold the comfortable illusion that we are speaking to each other in some comprehensible, commonsensical way. The bad thing is that the uncontrolled use of DC has swept us into a state of conceptual disorder that more and more acts as a barrier to subdisciplinary communication, theorybuilding, and accumulation of knowledge. To the misfortune of "the protoscience of consolidology" (Schmitter and Santiso 1997), Geoffrey Pridham's observation made in 1990, according to which democratic consolidation was a "nebulous concept" $(1990,8)$, has not lost its unpleasant validity since then. Still "no clear consensus has emerged" (Gunther et al. 1995, 5) as to the meaning of DC. Quite to the contrary, the conceptual fog that covers the term has apparently become even thicker and denser the more students of democratization have paid attention to it (SCHEDLER, 1997, p. 03).

Schneider e Schmitter (2004) afirmam que a consolidação para a democracia se apresenta como um termo mais controverso do que a liberalização ou a transição democrática. Para os autores, a consolidação é definida em bases de confiança mútua entre os principais atores políticos, buscando institucionalizar as certezas e incertezas do jogo democrático. Dessa forma, classificam esse processo como:

Regime consolidation consists in transforming the accidental arrangements, prudential norms and contingent solutions that have emerged during the uncertain struggles of the transition into institutions, that is, into relationships that are reliably known, regularly practiced and normatively accepted by those persons or collectivities defined as the participants/citizens/subjects of such institutions; and in such a way that the ensuing channels of access, patterns of inclusion, resources for action, and norms about decision making conform to one overriding standard: that of citizenship (SCHNEIDER; SCHMITTER, 2004, p. 62).

A consolidação democrática é importante para o estudo proposto na presente tese porque poderá explicar o cenário de sucesso da transição democrática dos PALOP insulares - Cabo Verde e São Tomé e Príncipe. Apesar das supracitadas indefinições que permeiam a consolidação democrática, grande parte dos acadêmicos adota o Procedural Mínimo de Dahl como sendo o referencial para mensurar a existência da democracia e a sua qualidade em determinado Estado. Os parágrafos a seguir apresentarão as concepções mais clássicas de consolidação democrática presentes na literatura. Por meio dessa 
explanação, será possível compreender as singularidades distinções entre a transição e consolidação da democracia.

Gasiorowski e Power (1998) definem consolidação democrática como o processo no qual um novo regime democrático se torna tão suficientemente durável e estável, que faz com que o retorno para o regime autoritário seja improvável. Para Linz e Stepan (1996), a transição democrática é completa quando as instituições democráticas se encontram estáveis. Por sua vez, Doyle (2011) argumenta que para que uma democracia se sustente, é necessária a participação popular, na qual os cidadãos estejam dispostos a pagar impostos, defender suas fronteiras e viver sob a regra da maioria.

Valenzuela (1992) acredita que a democracia em uma sociedade se apresenta consolidada quando o sistema se encontra estável. Nesse cenário, o primeiro passo para a consolidação ocorre por meio das oito condições mínimas propostas por Dahl. Para o autor, o aparato normativo é fundamental para a edificação de uma "institucionalização virtuosa", na qual regras legislativas e eleitorais conseguem impedir a presença do poder tutelar. Na consolidação democrática, as eleições expressam a maneira legítima com a qual o governo se forma e os grupos sociais são representados.

Larry Diamond (1999) afirma que o fator primordial para a democracia se consolidar é sua legitimação. Destarte, ela deve estar presente em fatores como combate à corrupção e violência, acesso ao judiciário e desenvolvimento da economia. $\mathrm{O}$ autor acredita que a consolidação se edifica como um fenômeno pautado na legitimidade, que abarca inúmeros níveis sociais que consideram a democracia como a melhor forma de governo, tais como: as elites, os tomadores de decisão, os formuladores de opinião, os partidos, as organizações e movimentos sociais e as massas. Nesse processo, ocorre o aprofundamento democrático com o reconhecimento dos valores do novo regime, resultando na mudança da cultura política da sociedade, denotada na transformação do aparato legal e do comportamento dos cidadãos, que passam a contestar pela melhora contínua da qualidade da democracia.

Doze indicadores foram escolhidos por Schneider e Schmitter (2004) para mensurar o complexo momento que abarca a consolidação democrática, elucidando características importantes que devem estar presentes para que a consolidação da democracia ocorra em determinado país, a saber: 
a) Nenhum partido político significativo advoga por grandes mudanças na Constituição vigente;

b) Eleições regulares são realizadas e os seus resultados são respeitados por aqueles que estão em posições de autoridade pública e pelos principais partidos de oposição;

c) Eleições são livres e justas;

d) Nenhum grupo ou partido significativo rejeita as condições eleitorais anteriores;

e) Significativa diminuição da volatilidade eleitoral;

f) Os oficiais e representantes eleitos não são constrangidos pelo seu comportamento pelos grupos de veto que não foram eleitos dentro do país;

g) A primeira alternância de poder ou mudanças significativas de alianças dos partidos no poder ocorre de acordo com as regras já estabelecidas;

h) A segunda alternância de poder ou mudanças significativas de alianças dos partidos no poder ocorre de acordo com as regras já estabelecidas;

i) Acordos, formais e informais, são alcançados de acordo com as regras referentes ao comportamento e formação de associações;

j) Acordos, formais e informais, são alcançados de acordo com as regras referentes ao formato executivo;

k) Acordos, formais e informais, são alcançados de acordo com as regras referentes às competências das divisões territoriais;

1) Acordos, formais e informais, são alcançados de acordo com as regras referentes às regras de propriedade e acesso à grande mídia.

Considerando a literatura exposta, tem-se na figura a seguir um resumo das três fases do processo de democratização, mencionando as suas principais definiçõoes e características de acordo com o conteúdo exposto e debatido nesta revisão de literatura. 
Figura 6 - Fases da democratização - Síntese sobre a definição dos principais conceitos
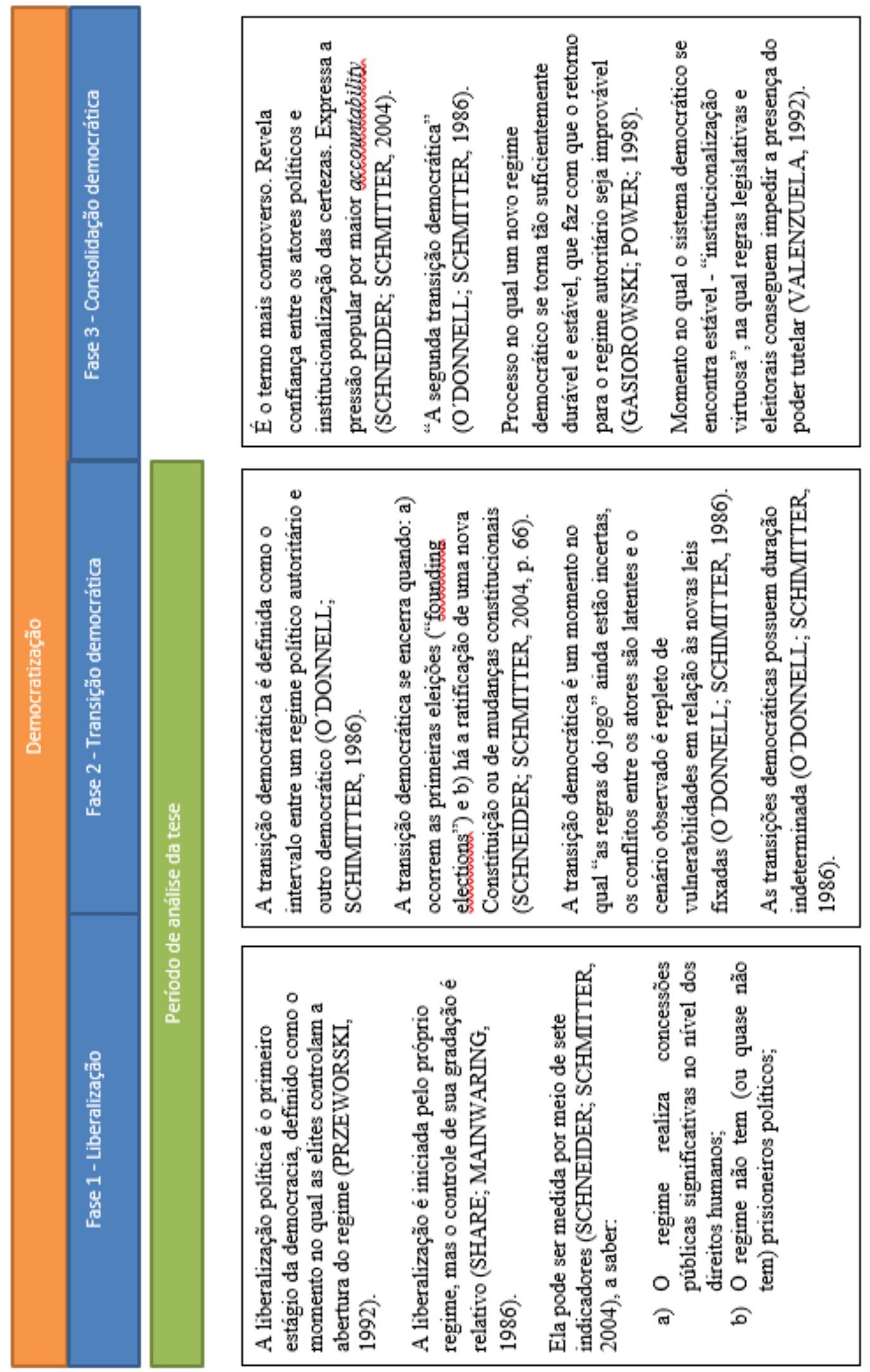


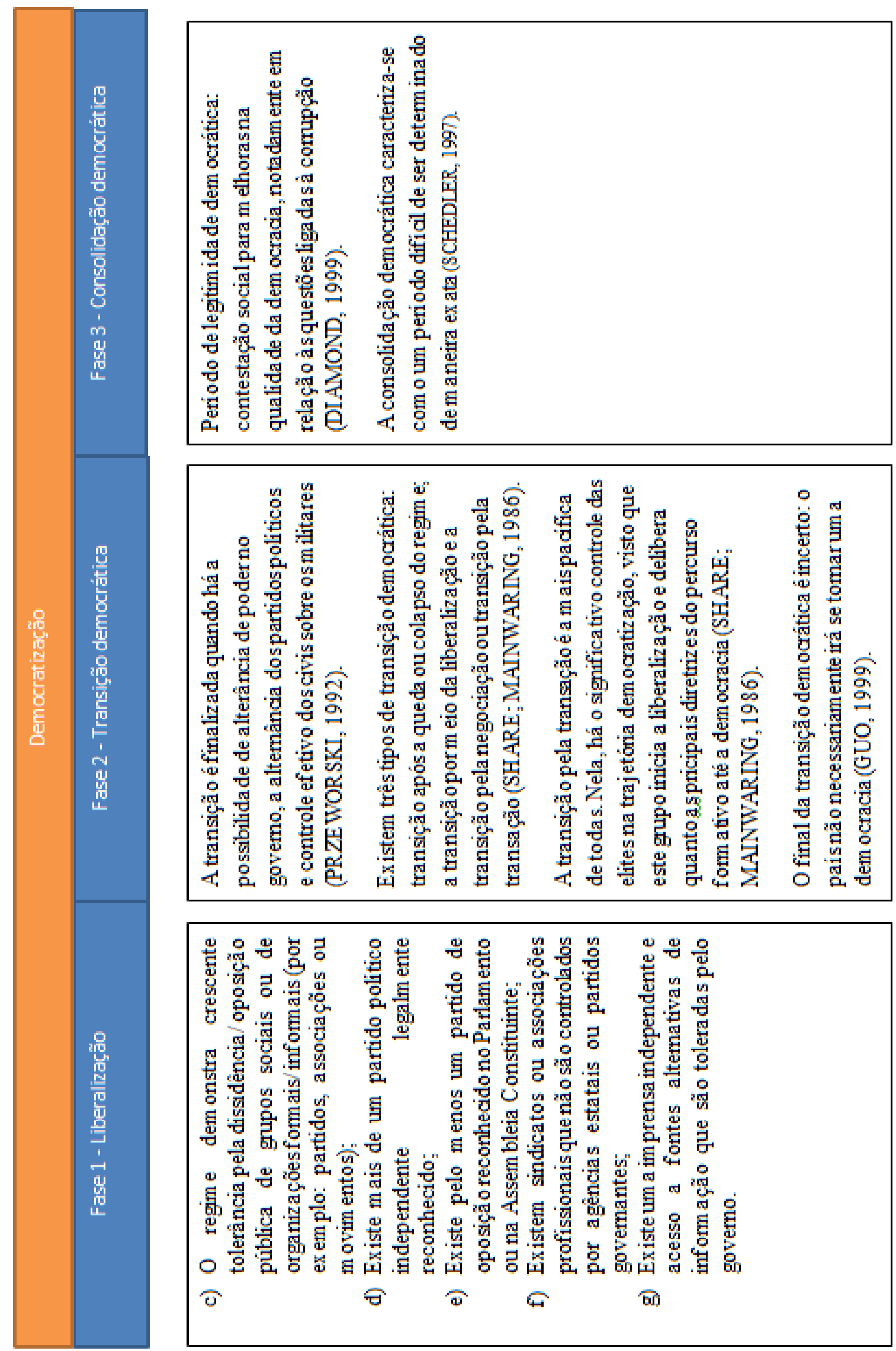

Fonte: Figura elaborada pela autora. 
O primeiro Capítulo da presente tese permitiu concluir que, no amplo universo permeado pela multiplicidade de pensamentos e correntes teóricas na literatura de democratização, foi possível identificar as abordagens que explicam e se encaixam à proposta da presente investigação. Dessa forma, os principais objetivos cumpridos se expressaram em: a) delimitar o conceito de democracia, b) identificar as transições democráticas dos PALOP no contexto das ondas de democratização, c) verificar as teorias sobre transição democrática, d) apresentar o diálogo entre transição democrática e ajuda internacional e e) apontar as características da consolidação democrática. O próximo capítulo será destinado a descrever a metodologia deste trabalho e expor a motivação da escolha das variáveis e a sua importância para compreender a cadeia causal elaborada. 


\title{
CAPÍTULO 2 - O MÉTODO COMPARADO COMO UM INSTRUMENTO DE ANÁLISE DA DEMOCRATIZAÇÃO DA ÁFRICA LUSÓFONA
}

\author{
Research is to see what everybody else has seen, and think what \\ nobody has thought. \\ Genius is seeing what everyone else sees and thinking what no one \\ else has thought. \\ Discovery consists of seeing what everybody has seen and thinking \\ what nobody has thought. \\ The task is, not so much to see what no one has seen yet; but to think \\ what nobody has thought yet, about what everybody sees \\ (ALBERT SZENT-GYORGYI, Ganhador do Prêmio Nobel de \\ Medicina em 1937).
}

O presente capítulo será dividido em duas partes e abordará aspectos específicos da metodologia utilizada na construção deste estudo doutoral. Dessa forma, na primeira parte serão analisadas as principais premissas do método comparado, relacionando-as ao desenho de pesquisa e à construção da cadeia causal pautada na democratização dos PALOP. Na segunda parte, todas as variáveis que compõem a referida cadeia serão analisadas vis-à-vis a literatura de liberalização e transição democráticas. Nesse escopo, será apontada a importância de cada variável para a investigação, contextualizando-as, quando possível, ao universo da democracia no continente africano.

\section{Parte I - Política Comparada no contexto de democratização dos PALOP}

1. A aplicação do método comparado aos processos de democratização dos PALOP no pós-Guerra Fria

Para Sartori (1994), comparar é controlar, entender e explicar. Na concepção do autor a comparação é um instrumento que propicia a obtenção de padrões, expressos por semelhanças e diferenças que nos permitem, por meio de uma análise criteriosa de casos, obter respostas para importantes questionamentos científicos. Collier (1993) considera a 
comparação uma ferramenta essencial para análise dos mais variados fenômenos sociais. Ele também afirma que a comparação melhora o poder de descrição, exercendo um papel central na formação de conceitos.

De acordo com Wiarda (2000), os custos de se estudar somente um país são menores quando comparados ao estudo dedicado a vários países em perspectiva comparada. Entretanto, comparar, além de ser divertido, permite criar teorias explanatórias considerando o amplo conjunto de Estados, territórios, colônias, e outras organizações que compõem o globo. Nesse contexto, ele equipara o mundo a um laboratório vívido e em constante transformação, conforme se verifica abaixo:

Comparative Politics is a very rich and dynamic field. It is especially rich because its range of inquiry, its laboratory - really is a living, everchanging laboratory - is all the world's political systems. As of this writing, this includes some 190 countries, plus assorted territories, colonies, and other entities (WIARDA, 2000, p. 01).

A importância da comparação também é ressaltada por Lipset (1997), que afirma ser impossível compreender plenamente um país sem observar a maneira que ele se difere de outros Estados, a saber: "As I have frequently argued, it is impossible to understand a country without seeing how it varies from others. Those who know only one country know no country" (LIPSET, 1997, p. 01).

Após analisar a relevância da comparação, é fundamental entender as suas técnicas específicas. Sartori afirma que comparar é consiste em uma tarefa difícil, sendo a Política Comparada classificada como um campo de estudos definido primordialmente pelo seu método. A primeira premissa que deve ser considerada para realizar uma comparação consiste em: o que é realmente comparável? O autor afirma que, normalmente, se argumenta que maçãs e peras não são comparáveis. Mas como é que se vai saber disso a não ser que elas sejam comparadas? Nesse sentido, pedras e macacos seriam comparáveis? Da mesma forma, mesmo para declarar que a comparação entre ambos não é possível, deve-se ao menos, por um momento, tentar compará-los. Contudo, se o que está sendo comparando não tiver qualquer característica em comum, tem-se que o estudo não apresenta um interesse científico para ser realizado (SARTORI, 1994). 
A comparação depende da perspectiva que se adota. Peras e maçãs são comparáveis no que tange a algumas das propriedades que compartilham, e não comparáveis no que se refere às propriedades que não são semelhantes entre si. Nesse contexto, são comparáveis como frutas, como coisas que podem ser comidas, como entidades que crescem em árvores, mas incomparáveis, por exemplo, em relação ao seu formato (SARTORI, 1994). Logo, para se comparar, é necessário considerar determinadas propriedades fundamentais. Um questionamento importante que surge ao se realizar uma investigação sobre os PALOP é: esses países realmente são comparáveis? Será que as inúmeras diferenças entre as suas cinco realidades impossibilitariam uma comparação robusta e fidedigna dos seus processos de democratização? De fato, quando se analisa de maneira mais aprofundada a estrutura doméstica de cada país, discrepâncias significativas são observadas. Contudo, apesar da historicidade singular e da dinâmica interna própria presente nas suas realidades, é possível identificar no âmbito dos PALOP, conforme apresentado na Introdução, determinadas características comuns que fazem com que sejam comparáveis uns aos outros. Collier (1993) afirma que as comparações devem ser realizadas entre entidades nas quais os atributos se apresentem parcialmente compartilhados (similares) e parcialmente não compartilhados (incomparáveis). Esse cenário é observado no universo do PALOP, conforme se observará na cadeia causal que será exposta do decorrer deste capítulo.

Apesar de se mostrarem como bons instrumentos para avaliação de hipóteses, os estudos comparativos sacrificam o entendimento de um contexto específico em detrimento da inclusão, ou seja, "one knows less about more" (COLLIER, 1993). Dessa forma, esse tipo de investigação resulta, em muitos casos, em premissas generalizantes. Compreende-se, nesse ínterim, o caráter abrangente do modelo proposto na hipótese desta tese, que já testou a sua aplicabilidade na Alemanha, Japão, Afeganistão e Iraque, sendo testado nesse trabalho nos casos de Cabo Verde, São Tomé e Príncipe, Moçambique, Guiné-Bissau e Angola.

Sartori (1994) afirma que é necessário comparar quando existem muitas variáveis e poucos casos de análise, cenário que se observa no presente estudo e que explica a importância do referido método para esta pesquisa. Nesse cenário, a combinação de variáveis e o emprego de teorias parcimoniosas fazem com que essa questão seja minimizada e melhor empregada na abordagem comparada. No escopo da tese, a variável 
independente principal, representada pela estabilidade social, política e econômica dos PALOP no momento da transição democrática, reflete a combinação (em maior ou menor grau) de todas as outras variáveis independentes antecedentes apresentadas na cadeia causal. Esse fator faz com que o entendimento dos desdobramentos cadeia causal sejam melhor compreendidos, conforme será mencionado na parte 2 deste capítulo.

Por fim, tem-se como uma das limitações do método comparado o fato de que ele apresenta bases mais fracas do que o método experimental ou estatístico para avaliar hipóteses, devido ao pouco controle experimental e ao problema de muitas variáveis e “small $N$ ”. Contudo, oferece uma base mais forte para avaliar hipóteses do que os estudos de caso. Deschouwer (2016) afirma que a lógica comparativa se encontra em um estágio intermediário entre as lógicas quantitativa e qualitativa, a saber:

\section{Gráfico 6 - Lógicas de comparação científica: casos e aspectos (DESCHOUWER, 2016)}

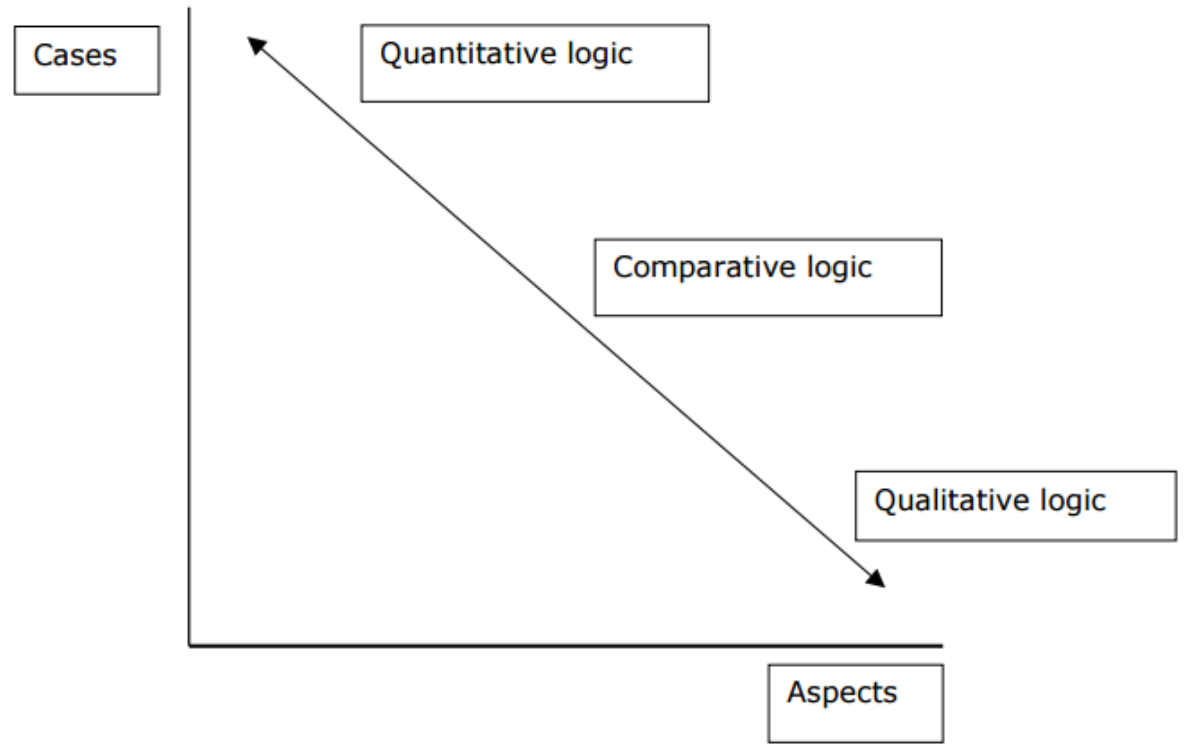

Fonte: DESCHHOUWER, 2016, s.p.

Após compreender os principais aspectos da Política Comparada e da sua instrumentalização na presente tese, no tópico seguinte será realizada a análise do desenho da "Mais Semelhança", que foi o desenho de pesquisa escolhido para comparar os PALOP. 


\section{Modelos de Comparação e desenho de pesquisa da tese}

Nas análises comparadas de um pequeno número de casos (Small $N)$, é possível elaborar a pesquisa utilizando os desenhos da "Mais Semelhança" ou da "Mais Diferença" de Przeworski e Teune (1970). Esses modelos permitem um maior controle da investigação, fazendo com que os pesquisadores identifiquem de maneira mais precisa os impactos das variáveis independentes na variável dependente.

Sartori (1994) afirma que a maioria dos comparativistas adota o desenho da "mais semelhança". Esse desenho visa a identificar o maior número possível de semelhanças e a menor quantidade de diferenças entre os casos analisados, apresentando também as seguintes características:

Tal desenho visa a diminuir o número de variáveis experimentais, fornecendo um escopo explicativo mais amplo para os fenômenos que possuam relações causais facilmente identificadas dentro de um sistema. Como exemplos, podem ser citados países com características semelhantes - expressas por fatores culturais, econômicos e políticos (QUEIROZ, 2012, p. 59).

O desenho de pesquisa da "Mais Semelhança" pode ser observado na tabela abaixo:

Tabela 3 - Desenho da Mais Semelhança (PRZEWORSKI; TEUNE, 1970)

\begin{tabular}{|l|l|l|l|l|l|}
\hline $\begin{array}{l}\text { Países/ } \\
\text { Variáveis }\end{array}$ & VI1 & VI2 & VI3 & VI4 & VD \\
\hline País A & S & S & S & S & S \\
\hline País B & S & S & S & N & N \\
\hline
\end{tabular}

\section{Valores:}

VI1: Variável independente 1; VI2: Variável independente 3; VI3: Variável independente 3; VI4: Variável independente 4 e VD: Variável dependente.

$\mathrm{S}=$ existência de determinada característica;

$\mathrm{N}=$ ausência de determinada característica.

Fonte: QUEIROZ, 2012, p. 59. 
Conforme verificado na tabela, o desenho apresenta países com muitas semelhanças e poucas diferenças, sendo que os resultados distintos na variável dependente são explicados pela(s) variável(is) independentes que apresentam valores divergentes.

As variáveis que serão analisadas com o referido desenho encontram-se presentes na cadeia causal elaborada de maneira específica para cada estudo comparado. Nesta tese, para explicar as relações de correlação ou causalidade, a cadeia causal construída para analisar a democratização dos PALOP utilizará o process tracing ${ }^{19}$. Este método considera a multicausalidade do universo que se deseja compreender, englobando todos os fenômenos que o constituem. De acordo com Rezende (2011):

\begin{abstract}
As abordagens process tracing emergem como alternativas para a produção de inferências causais quando não se faz possível utilizar o conhecido método de comparações controladas. Nestas condições, o pesquisador deve estar atento ao importante fato de que variáveis que supostamente seriam controláveis, podem estar gerando efeitos causais de importância para a análise. Os métodos de process tracing se prestam, portanto, para trabalhar com a compreensão destes efeitos, refinando os métodos comparativos usuais (REZENDE, 2011, p. 324).
\end{abstract}

Considerando os conceitos expostos, tem-se que a metodologia utilizada na presente tese irá se basear na concepção do modelo de "Mais Semelhança", abarcando também uma análise dinâmica e menos controlada das variáveis, tendo como estrutura o process tracing. Nos Capítulos 3, 4 e 5, serão realizados estudos de caso nos quais as variáveis expostas na cadeia causal serão analisadas e aplicadas à realidade de cada PALOP, demonstrando a inter-relação dos contextos históricos, sociais, econômicos e políticos desses países para os seus processos de liberalização e transição democrática. Dessa forma, esses estudos permitirão compreender de maneira mais aprofundada diversos aspectos importantes que influenciaram o sucesso ou insucesso da democracia na África Lusófona.

\footnotetext{
${ }^{19}$ De acordo com Beach e Pedersen (2011), o process tracing (PT) pode ser definido como "the ambition to trace causal mechanisms [...] Studying causal mechanisms in qualitative in-depth single case studies using PT enables the researcher to make strong within-case inferences about how outcomes come about, updating the level of confidence we have in the validity of theorized causal mechanism. [...] PT involves, '...attempts to identify the intervening causal process - the causal chain and causal mechanism - between an independent variable (or variables) and the outcome of the dependent variable' (George and Bennett 2005:206-207)" (BEACH; PEDERSEN, 2011, p. 04).
} 
De acordo com Arendt Lijphart (1971), a metodologia pautada no estudo de caso é importante porque, ao se focar em um único caso ou em poucos casos, permite que a pesquisa realizada se focalize de maneira muito específica no escrutínio de determinado assunto. Adicionalmente, estudos de caso podem resultar em contribuições importantes para a construção e o aprimoramento teórico, visto que determinados padrões podem ser inferidos pela utilização desse método. A partir disso, tanto Lijphart (1971) quanto Johnson \& Joslyn (1991) definiram alguns tipos ideais de estudo de caso e o modo como eles podem contribuir para a construção do conhecimento científico. O modelo que será adotado neste trabalho é o denominado comparative or multiple case study, que abrange casos nos quais fatores considerados importantes por determinadas teorias serão apresentados e analisados no decorrer da tese.

\section{Construção da cadeia causal baseada na democratização dos PALOP}

A análise da democratização dos PALOP será realizada considerando um conjunto específico de variáveis que, de acordo com a literatura sobre democratização, são essenciais para explicar o êxito ou insucesso da sua transição para a democracia liberal. Visando a construir uma análise mais completa e holística do estudo, essas variáveis serão destinadas a explicar três universos temporais distintos, a saber: a) período colonial pré-independência; b) período do partido único que abrange o imediato pósindependência até o fim da Guerra Fria e c) pós-Guerra Fria até a atualidade.

Durante o período colonial, dez variáveis foram escolhidas para a análise dos PALOP no âmbito da cadeia causal. Essas variáveis independentes antecedentes são importantes porque, além de mostrarem a grande semelhança que existia nos PALOP antes de 1975, são fundamentais para explicar a trajetória democrática que foi traçada por cada país após a sua soberania nacional. Essas variáveis são:
a) localização geográfica;
b) domínio português;
c) crescimento econômico;
d) desenvolvimento social;
e) insularidade e microestado;
f) direitos políticos e liberdades civis;
g) recursos naturais; 
h) diversidade étnica;

i) guerra de independência e

j) independência de Portugal.

Já no período do regime de partido único, que compreende os anos de 1974/1975 à década de1990, seis variáveis independentes antecedentes foram escolhidas para serem analisadas, a saber:
a) instauração de Repúblicas Populares de influência soviética;
b) direitos políticos e liberdades civis;
c) crescimento econômico;
d) desenvolvimento social;
e) perfil das elites políticas e
f) guerra civil.

No final da década de 1980 e início de 1990, tem-se que a combinação de todas essas variáveis gerou um cenário de estabilidade ou instabilidade social, política e econômica em cada um dos PALOP. Por esse motivo, a variável independente principal desse estudo é denominada "estabilidade social, política e econômica", sendo fundamental destacar que ela engloba na sua essência o resultado da interação de todas as variáveis apresentadas anteriormente. Por fim, a última variável identificada nesse momento histórico refere-se à variável externa, representada nesse trabalho pelas pressões internacionais para a democratização, primordialmente depois do fim da URSS.

O terceiro período analisado encontra-se focalizado na democratização dos PALOP e tem como objetivo principal descrever a compreender os seus processos de liberalização e transição democrática. Conforme citado no capítulo anterior, no universo da África lusófona essas duas fases não aconteceram de maneira linear, tendo como característica a aglutinação de inúmeros elementos híbridos presentes em ambas. Por esse motivo, é importante analisar a cadeia causal de maneira dinâmica e complexa, interpretando-a de forma ampla e interdependente.

Nesse contexto, os 25 anos subsequentes a 1990 serão analisados sob a égide de seis variáveis independentes intervenientes, a saber:

a) liberalização política; 
b) direitos políticos e liberdades civis,

c) crescimento econômico;

d) desenvolvimento social;

e) criação de instituições democráticas e

f) alternância efetiva de poder partidário.

Por fim, a variável dependente pauta-se na democracia liberal, que apresenta um resultado positivo para os PALOP insulares e um resultado relativamente negativo para os PALOP continentais. Nesse cenário, ressalta-se que Moçambique detém, em 2017, um resultado intermediário da sua democracia liberal, sendo considerado como "parcialmente livre" pela Freedom House (2017).

A pergunta que surge nesse momento é: por que essas variáveis foram escolhidas e por que elas influenciam e explicam a democratização dos PALOP? Para responder a tal questionamento, será realizada uma análise das principais variáveis que explicam o sucesso ou insucesso da trajetória democrática dos PALOP, demonstrando o motivo da sua escolha para a estrutura de investigação desta tese.

De acordo com Lipset (1959), a análise do padrão de comportamento de determinado sistema social deve resultar em hipóteses específicas com premissas empiricamente passíveis de serem testadas. Ao abordar essa questão no escopo da democracia, ele afirma que

\begin{abstract}
Thus, in dealing with democracy, one must be able to point to a set of conditions that have actually existed in a number of countries, and say: democracy has emerged out of these conditions, and has become stabilized because of certain supporting institutions and values, as well as because of its own internal self-maintaining processes. The conditions listed must be ones which differentiate most democratic states from most others (LIPSET, 1959, p. 69).
\end{abstract}

Dessa forma, foram selecionadas para fazer parte da cadeia causal deste estudo variáveis que pudessem ser testadas e que tivessem o potencial de explicar ou sucesso ou insucesso da democracia nos PALOP. Considerando o cenário supracitado, a cadeia causal elaborada e as variáveis propostas para a análise são: 
Figura 7 - "Process Tracing": Trajetória democrática dos PALOP

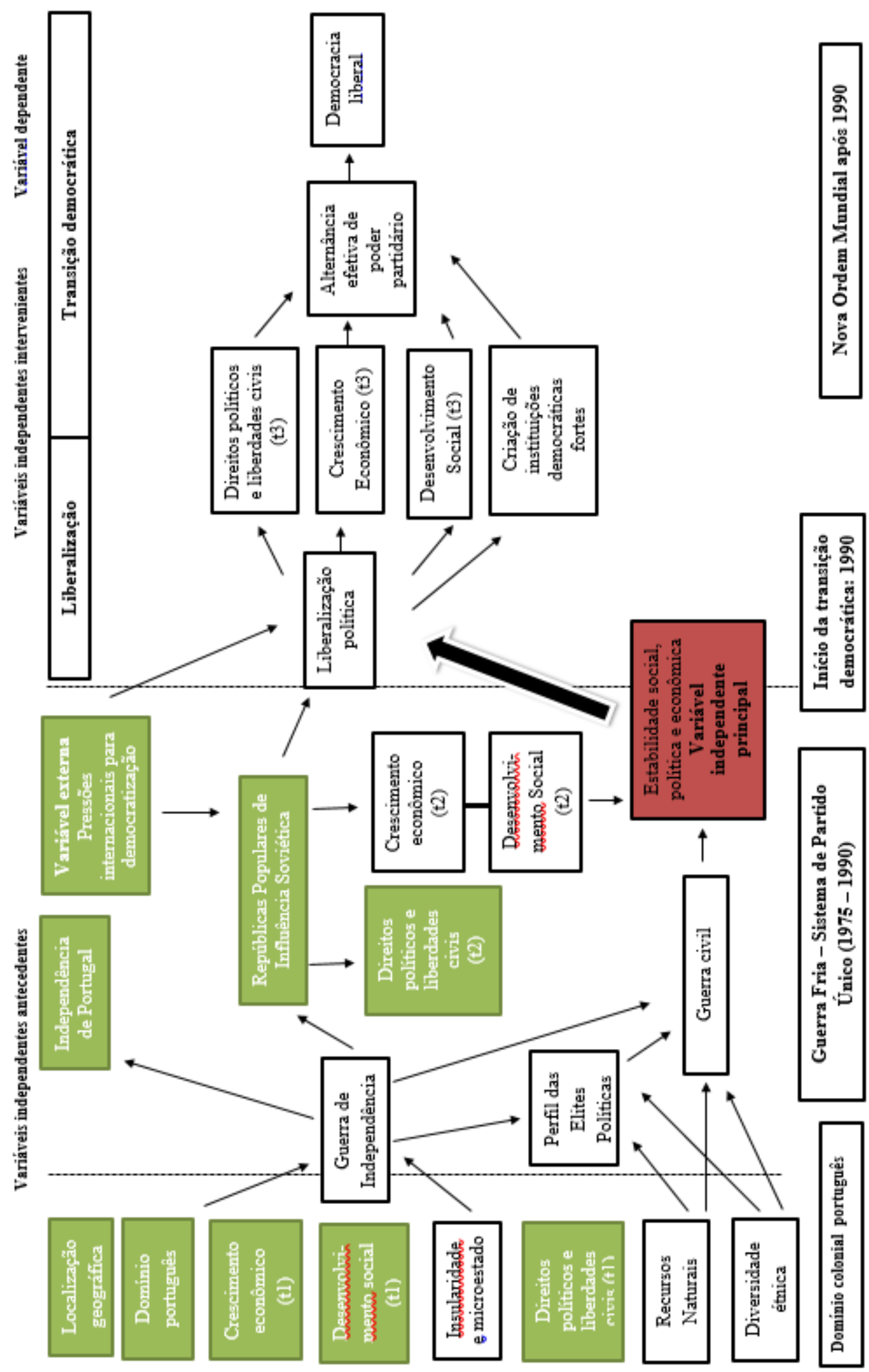

Fonte: Figura elaborada pela autora. 


\section{Valores das variáveis presentes na cadeia causal}

Período histórico: dominação colonial portuguesa no século XX (1950 - 1975)

\section{Variáveis independentes antecedentes (VIA) ${ }^{20}$ :}

- $\quad$ VIA1 $\rightarrow$ Localização geográfica:

$\mathrm{S}=$ localização no continente africano;

$\mathrm{N}=$ localização fora do continente africano.

- $\quad$ VIA $2 \rightarrow$ Domínio português:

$\mathrm{S}=$ existência do legado colonial português;

$\mathrm{N}$ = inexistência do legado colonial português.

- $\quad$ VIA $3 \rightarrow$ Crescimento econômico (t1):

$\mathrm{S}=$ alto crescimento econômico durante o domínio colonial português, medido por meio da taxa de crescimento do PIB (V-DEM) e do PIB per capita (V-DEM);

$\mathrm{N}$ = baixo crescimento econômico durante o domínio colonial português, medido por meio da taxa de crescimento do PIB (V-DEM) e do PIB per capita (V-DEM).

\footnotetext{
${ }^{20}$ É importante destacar que todas variáveis de controle no momento do domínio colonial e do partido único apresentam a coloração verde na cadeia causal, de modo a facilitar a sua identificação. Do mesmo modo, a VIP encontra-se com a coloração vermelha e com uma seta diferenciada focalizando o seu impacto na liberalização política. Esses efeitos visuais foram retratados na cadeia causal com a finalidade de auxiliar a compreensão de leitor, tendo em vista a expressiva quantidade de variáveis apresentadas.
} 
- $\quad$ VIA $4 \rightarrow$ Desenvolvimento social (t1):

$\mathrm{S}=$ alto desenvolvimento social durante o governo colonial, medido por meio das taxas de a) expectativa de vida (V-DEM); b) mortalidade infantil (V-DEM) e c) analfabetismo (FERREIRA, 2014) e taxa de matrícula no ensino primário (V-DEM);

$\mathrm{N}$ = baixo desenvolvimento social durante o governo colonial, medido por meio das taxas de a) expectativa de vida (V-DEM); b) mortalidade infantil (V-DEM) e c) analfabetismo (FERREIRA, 2014) e taxa de matrícula no ensino primário (V-DEM).

- $\quad$ VIA $5 \rightarrow$ Insularidade e microestado:

$\mathrm{S}$ = o país é um microestado constituído por um arquipélago;

$\mathrm{N}$ = o país não é um microestado e não é constituído por um arquipélago.

- VIA $6 \rightarrow$ Direitos políticos e liberdades civis (t1):

$\mathrm{S}=$ presença de direitos políticos e liberdades civis, medidos por meio do Índice de Democracia Eleitoral (V-DEM) e do Índice de Componentes Liberais (V-DEM), abrangendo questões como a existência de sufrágio universal, eleições periódicas, livres e justas, sistema multipartidário, alternância de poder, possibilidade de que qualquer cidadão possa se candidatar a cargos eletivos, liberdade de expressão e liberdade de imprensa no período colonial;

$\mathrm{N}$ = ausência de direitos políticos e liberdades civis, medidos por meio do Índice de Democracia Eleitoral (V-DEM) e do Índice de Componentes Liberais (V-DEM), abrangendo questões como a existência de sufrágio universal, eleições periódicas, livres e justas, sistema multipartidário, alternância de poder, possibilidade de que qualquer cidadão possa se candidatar a cargos eletivos, liberdade de expressão e liberdade de imprensa no período colonial 
- $\quad$ VIA $7 \rightarrow$ Recursos naturais:

$\mathrm{S}=$ presença de recursos naturais expressivos no país;

$\mathrm{N}=$ ausência de recursos naturais expressivos no país.

- VIA $8 \rightarrow$ Diversidade étnica:

$\mathrm{S}=$ presença de uma relativa homogeneidade étnica, religiosa e cultural;

$\mathrm{N}=$ ausência de homogeneidade étnica, religiosa e cultural.

- $\quad$ VIA $9 \rightarrow$ Guerra de independência:

$\mathrm{S}=$ presença de guerras de independência contra Portugal;

$\mathrm{N}$ = ausência de guerras de independência contra Portugal.

- VIA $10 \rightarrow$ Independência de Portugal:

S = sucesso na obtenção da independência de Portugal entre 1973 e 1975;

N = insucesso na obtenção da independência de Portugal entre 1973 e 1975. 
Período histórico: instauração de regimes de partido único no pós-independência de Portugal (1973/1975 - década de 1990)

\section{Variáveis independentes antecedentes (VIA):}

- VIA $11 \rightarrow$ Repúblicas Populares de influência soviética:

$\mathrm{S}=$ presença de Repúblicas Populares com um regime de partido único com forte influência da URSS durante o pós-independência;

$\mathrm{N}=$ ausência de Repúblicas Populares com um regime de partido único com forte influência da URSS durante o pós-independência.

- $\quad$ VIA $12 \rightarrow$ Direitos políticos e liberdades civis (t2):

$\mathrm{S}=$ presença de direitos políticos e liberdades civis, medidos por meio do Índice de Democracia Eleitoral (V-DEM) e do Índice de Componentes Liberais (V-DEM), abrangendo questões como a existência de sufrágio universal, eleições periódicas, livres e justas, sistema multipartidário, alternância de poder, possibilidade de que qualquer cidadão possa se candidatar a cargos eletivos, liberdade de expressão e liberdade de imprensa no durante o regime de partido único;

$\mathrm{N}=$ ausência de direitos políticos e liberdades civis, medidos por meio do Índice de Democracia Eleitoral (V-DEM) e do Índice de Componentes Liberais (V-DEM), abrangendo questões como a existência de sufrágio universal, eleições periódicas, livres e justas, sistema multipartidário, alternância de poder, possibilidade de que qualquer cidadão possa se candidatar a cargos eletivos, liberdade de expressão e liberdade de imprensa no durante o regime de partido único. 
- VIA $13 \rightarrow$ Crescimento econômico (t2):

$\mathrm{S}=$ alto crescimento econômico no pós-independência (1975-1990), medido por meio da taxa de crescimento do PIB (V-DEM) e pelo índice de inflação (FMI);

$\mathrm{N}$ = baixo crescimento econômico no pós-independência (1975-1990), medido por meio da taxa de crescimento do PIB (PIB) e pelo índice de inflação (FMI).

- $\quad$ VIA $14 \rightarrow$ Desenvolvimento social (t2):

$\mathrm{S}=$ alto desenvolvimento social durante o regime de partido único, medido por meio das taxas de a) expectativa de vida (V-DEM); b) mortalidade infantil (V-DEM) e c) quantidade de anos de escolaridade dos cidadãos com idade superior a 15 anos (V-DEM);

$\mathrm{N}$ = baixo desenvolvimento social durante o regime de partido único, medido por meio das taxas de a) expectativa de vida (V-DEM); b) mortalidade infantil (V-DEM) e c) quantidade de anos de escolaridade dos cidadãos com idade superior a 15 anos (V-DEM).

- VIA $15 \rightarrow$ Perfil das elites políticas:

$\mathrm{S}=$ elites políticas mais flexíveis e dispostas a realizar a democratização;

$\mathrm{N}=$ elites políticas inflexíveis e com pouca disposição para realizar a democratização.

- VIA $16 \rightarrow$ Guerra civil:

$\mathrm{S}=$ presença de guerra civil após a independência de Portugal (não somente no período de partido único, mas também depois de 1990);

$\mathrm{N}$ = ausência de guerra civil após a independência de Portugal (não somente no período de partido único, mas também depois de 1990). 


\section{Período histórico: início da democratização em 1990}

\section{Variável independente Principal (VIP):}

- $\quad$ VIP $\rightarrow$ Estabilidade social, política e econômica:

$\mathrm{S}=$ presença de estabilidade social, política e econômica no momento da democratização, sendo essa variável medida por meio de uma análise combinada de todas as VIA presentes na cadeia causal;

$\mathrm{N}$ = ausência de estabilidade social, política e econômica no momento da democratização, sendo essa variável medida por meio de uma análise combinada de todas as VIA presentes na cadeia causal.

\section{Variável Externa (VEXT):}

- VEXT $\rightarrow$ Pressões internacionais para a democratização:

$\mathrm{S}=$ presença de pressões internacionais para a democratização após o fim da URSS, sendo essa variável medida por meio da ajuda oficial para o desenvolvimento e da ajuda oficial advinda das potências Ocidentais durante o processo de democratização (BANCO MUNDIAL, 2017);

$\mathrm{N}$ = ausência de pressões internacionais para a democratização após o fỉm da URSS, sendo essa variável medida por meio da ajuda oficial para o desenvolvimento e da ajuda oficial advinda das potências Ocidentais durante o processo de democratização (BANCO MUNDIAL, 2017).

Momento histórico: decorrer da liberalização e transição democráticas após 1990

Variáveis independentes intervenientes (VII): 
- VII $1 \rightarrow$ Liberalização política:

S = presença da liberalização política na década de 1990;

N = ausência da liberalização política na década de 1990.

- VII $2 \rightarrow$ Direitos políticos e liberdades civis (t3):

$\mathrm{S}=$ presença de direitos políticos e liberdades civis, medidos por meio do Índice de Liberdades Civis (V-DEM) e do Índice de Eleições Livres e Justas (V-DEM), analisando também se a) o regime realiza concessões públicas significativas no nível dos direitos humanos; b) o regime não tem (ou quase não tem) prisioneiros políticos e o regime demonstra crescente tolerância pela dissidência/ oposição pública de grupos sociais ou de organizações formais/ informais (por exemplo: partidos, associações ou movimentos); c) existe mais de um partido político independente legalmente reconhecido e existe pelo menos um partido de oposição reconhecido no Parlamento ou na Assembleia Nacional e d) existe uma imprensa independente e acesso a fontes alternativas de informação que são toleradas pelo governo;

$\mathrm{N}^{*}=$ presença de alguns direitos políticos e algumas liberdades civis (estágio intermediário), medidos por meio do Índice de Liberdades Civis (V-DEM) e do Índice de Eleições Livres e Justas (V-DEM), analisando também se a) o regime realiza concessões públicas significativas no nível dos direitos humanos; b) o regime não tem (ou quase não tem) prisioneiros políticos e o regime demonstra crescente tolerância pela dissidência/ oposição pública de grupos sociais ou de organizações formais/ informais (por exemplo: partidos, associações ou movimentos); c) existe mais de um partido político independente legalmente reconhecido e existe pelo menos um partido de oposição reconhecido no Parlamento ou na Assembleia Nacional e d) existe uma imprensa independente e acesso a fontes alternativas de informação que são toleradas pelo governo;

$\mathrm{N}=$ ausência de grande parte dos direitos políticos e das liberdades civis, medidos por meio do Índice de Liberdades Civis (V-DEM) e do Índice de Eleições Livres e Justas (VDEM), analisando também se a) o regime realiza concessões públicas significativas no nível dos direitos humanos; b) o regime não tem (ou quase não tem) prisioneiros políticos 
e o regime demonstra crescente tolerância pela dissidência/ oposição pública de grupos sociais ou de organizações formais/ informais (por exemplo: partidos, associações ou movimentos); c) existe mais de um partido político independente legalmente reconhecido e existe pelo menos um partido de oposição reconhecido no Parlamento ou na Assembleia Nacional e d) existe uma imprensa independente e acesso a fontes alternativas de informação que são toleradas pelo governo.

- VII $3 \rightarrow$ Crescimento econômico (t3):

$\mathrm{S}=$ (relativamente) alto crescimento econômico durante o período de democratização, medido por meio da taxa de crescimento do PIB (V-DEM) e pelo índice de inflação (FMI) e taxa de desemprego (BANCO MUNDIAL);

$\mathrm{N}$ = baixo crescimento econômico durante o período de democratização, medido por meio da taxa de crescimento do PIB (PIB) e pelo índice de inflação (FMI) e taxa de desemprego (BANCO MUNDIAL).

- $\quad$ VII $4 \rightarrow$ Desenvolvimento social (t3):

$\mathrm{S}=$ (relativamente) alto desenvolvimento social durante o período da democratização, medido por meio das taxas de a) expectativa de vida (V-DEM); b) mortalidade infantil (V-DEM), c) quantidade de anos de escolaridade dos cidadãos com idade superior a 15 anos (V-DEM) e d) IDH (PNUD);

$\mathrm{N}$ = baixo desenvolvimento social durante o período da democratização, medido por meio das taxas de a) expectativa de vida (V-DEM); b) mortalidade infantil (V-DEM), c) quantidade de anos de escolaridade dos cidadãos com idade superior a 15 anos (V-DEM) e d) IDH (PNUD). 
- $\quad$ VII5 $\rightarrow$ Criação de instituições democráticas fortes (t3):

$\mathrm{S}=$ presença de instituições democráticas fortes durante a democratização;

$\mathrm{N}^{*}=$ presença de instituições democráticas relativamente fortes durante a democratização (estágio intermediário);

$\mathrm{N}=$ ausência de instituições democráticas fortes durante a democratização.

- VII6 $\rightarrow$ alternância efetiva de poder partidário:

$\mathrm{S}=$ presença de alternância efetiva de poder partidário;

$\mathrm{N}=$ ausência de alternância efetiva de poder partidário.

\section{Período histórico: 25 anos depois do início da democratização (2015)}

\section{Variável dependente:}

- VD: Democracia liberal:

$\mathrm{S}=$ sucesso da democratização com a implantação da democracia liberal, medida por meio da Freedom House e do Polity IV;

$\mathrm{N}^{*}=$ relativo insucesso da democratização com a implantação da democracia liberal de maneira "imperfeita" e em um estágio intermediário (parcialmente livre), medida por meio da Freedom House e do Polity IV;

$\mathrm{N}$ = insucesso da democratização sem a implantação da democracia liberal, medida por meio da Freedom House e do Polity IV. 


\section{Hipótese}

Conforme exposto na Introdução desta tese, a hipótese de que "o sucesso democrático dos PALOP insulares se explica devido à sua estabilidade social, política e econômica durante o processo de liberalização e transição democrática, enquanto o (relativo) insucesso democrático dos PALOP continentais se explica pela sua instabilidade nesse mesmo contexto" pode ser demonstrada por meio da tabela a seguir, que compara os valores da variável independente principal, da variável externa e da variável dependente.

Tabela 4 - As transições democráticas de Cabo Verde, São Tomé e Príncipe, Angola, Moçambique e Guiné-Bissau em perspectiva comparada

\begin{tabular}{|c|c|c|c|}
\hline $\begin{array}{c}\text { Variáveis/ } \\
\text { Países }\end{array}$ & VEXT & VIP & VD \\
\hline Cabo Verde & $\mathrm{S}$ & $\mathrm{S}$ & $\mathrm{S}$ \\
\hline $\begin{array}{c}\text { São Tomé e } \\
\text { Príncipe }\end{array}$ & $\mathrm{S}$ & $\mathrm{S}$ & $\mathrm{S}$ \\
\hline Angola & $\mathrm{S}$ & $\mathrm{N}$ & $\mathrm{N}$ \\
\hline Moçambique & $\mathrm{S}$ & $\mathrm{N}$ & $\mathrm{N}^{*}$ \\
\hline Guiné-Bissau & $\mathrm{S}$ & $\mathrm{N}$ & $\mathrm{N}$ \\
\hline
\end{tabular}

Fonte: Tabela elaborada pela autora.

Após a explicação realizada, percebe-se como o modelo exposto da Introdução da tese corresponde, de maneira parcimoniosa, aos principais aspectos abordados pelas inúmeras variáveis presentes na cadeia causal, destacando-se o fato de que a variável independente principal agrega nos seus valores os resultados combinados de todas as variáveis independentes antecedentes. Para uma melhor visualização da tabela acima visà-vis o supracitado modelo, tem-se novamente a exposição da figura do "Modelo de análise: democratização e intervenção externa" a seguir: 
Figura 8 - Modelo de análise: democratização e intervenção externa

Intervenção externa para a democratização

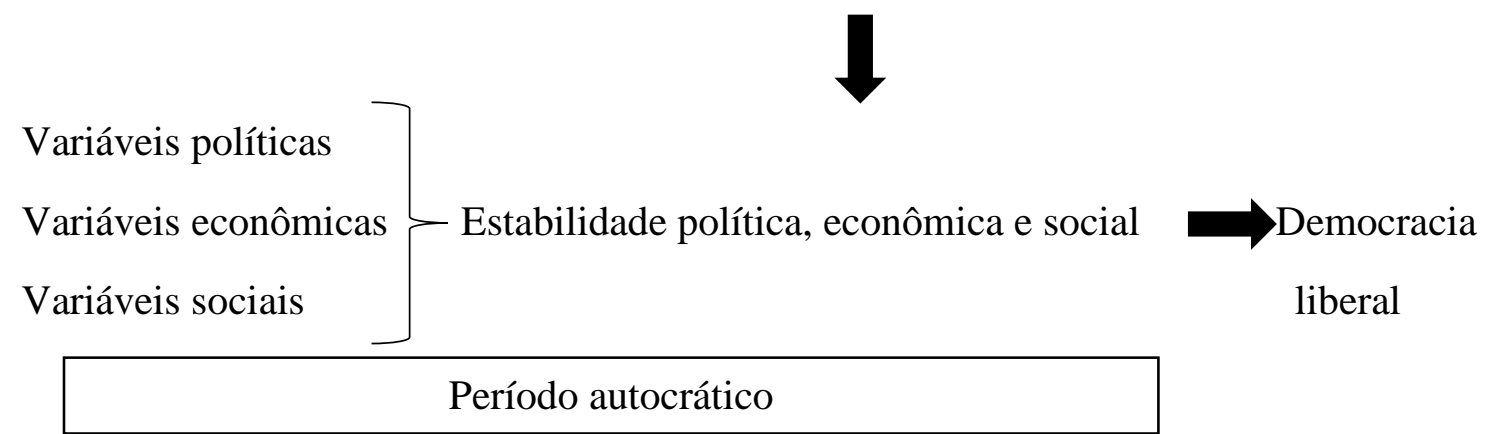

Fonte: Figura elaborada pela autora utilizando-se como base o modelo de análise desenvolvido na sua Dissertação de Mestrado (QUEIROZ, 2012).

A análise das variáveis apresentadas na supracitada cadeia causal permitirá identificar do papel que cada uma exerce para a democratização dos PALOP. Dessa forma, a multicausalidade exposta se estabelece como a estrutura principal que irá fundamentar a narrativa dos capítulos a seguir. Destarte, no próximo tópico, será realizado um estudo sobre a importância de cada variável no âmbito das teorias de liberalização e transição para a democracia, visando a explicar os motivos que justificam a sua presença neste trabalho de investigação. 


\section{Parte II - Análise das variáveis que integram a cadeia causal}

"Democracy is not a luxury for Africans" but a necessity if people are to lead free and secure lives (KPUNDEH, 1992, p. 09).

First, people will have to eat (in both literal and figurative senses.) There will be no democracy if the new generation of Africa's politicians continue to monopolise the fruits of Uhuru. Both food (material wealth) and political power will have to be shared. In addition, political leaders will have to respect the basic human rights of their citizens. They include - but are not limited to - food, clothing, shelter, and health care. The new political 'fathers' will have to provide these things or else run the risk of losing legitimacy - regardless of whether they came to power via a national conference, the ballot box, or the gun (SCHATZBERG, 1993, p. 457).

Conforme mencionado anteriormente, a segunda parte desse Capítulo será focalizada na análise de cada uma das variáveis presentes na cadeia causal, demonstrando a sua importância para a análise dos processos de democratização dos PALOP. É importante destacar que algumas dessas variáveis serão extensamente estudadas, enquanto outras serão trabalhadas de maneira rápida porque já foram escrutinizadas no universo da revisão de literatura presente no Capítulo 1 desta tese.

\section{Localização geográfica:}

A relação entre geografia e democracia é uma questão abordada por diversos autores. Isso se explica porque, para acadêmicos como Laurence Whitehead (1999), determinados lugares do mundo são mais propensos a se tornarem democráticos quando comparados a outros. Quando se observa o continente africano, nota-se que, de maneira geral, a sua democracia ainda se encontra em um estágio bastante incipiente. A seguir, será realizada uma abordagem sobre esse tema, permitindo contextualizar os PALOP no universo democrático da África.

No continente africano, a análise regional da democracia pode ser realizada das mais variadas maneiras. A sua principal macrodivisão política delimita o Norte da África e a África Subsaariana. Dos 54 países do continente, cinco se encontram na sua parte 
setentrional, a saber: Argélia, Egito, Líbia, Marrocos e Tunísia. Desse conjunto, três são classificados pela Freedom House (2016) como não-livres (50\%), um como parcialmente livre $(20 \%)$ e um como livre $(20 \%)^{21}$. Antes do início da Primavera Árabe em 2011 na Tunísia, todos os países setentrionais africanos eram considerados não-livres, com exceção do Marrocos (parcialmente livre), fazendo da região uma das mais autocráticas do mundo.

Na África Subsaariana, somente 12\% dos países são considerados livres, $49 \%$ parcialmente livres e 39\% não-livres (FREEDOM HOUSEb, 2016). Situado em um continente historicamente imerso em cenários de autocracias, os PALOP insulares se destacam como exemplos factíveis de Estados que conseguiram construir trajetórias exitosas na construção das suas democratizações após 1990, sendo ambos classificados como livres e tendo Cabo Verde alcançado a pontuação máxima de liberdade de acordo com a Freedom House (2016). Contudo, os PALOP continentais parecem seguir o a tendência do continente, sendo Moçambique classificado como parcialmente-livre, Guiné-Bissau como parcialmente-livre (porém menos livre do que Moçambique) e Angola como não-livre.

Além desta divisão política dicotômica, é possível analisar o contexto macrorregional africano por meio de cinco dimensões ${ }^{22}$ : Norte, Sul, Oriental, Ocidental e Central. O norte da África, conforme citado acima, é considerada uma região historicamente autocrática, fator que se modificou relativamente após os ganhos democráticos advindos da Primavera Árabe. O Sul da África representa o cenário diametralmente oposto, sendo o mais livre do continente. Composto por seis países, sendo eles África do Sul, Botswana, Lesoto, Maurícia, Namíbia e Suazilândia, quatro são considerados livres (67\%), sendo as exceções expressas por Lesoto, que é parcialmentelivre (16\%) e a Suazilândia, que é classificada como não-livre.

A África Oriental é composta por 16 países, nos quais nenhum é considerado livre. Nesse universo, Comores, Madagascar, Malawi, Moçambique, Quênia, Seychelles, Tanzânia, Zâmbia e Zimbábue são parcialmente-livres, totalizando 56\%. Já Burundi,

\footnotetext{
${ }^{21}$ O status da Freedom House para todos os países africanos encontra-se no Anexo B e os seus dados geográficos estão no Anexo C.

${ }^{22}$ Cinco macrorregiões africanas de acordo com a ONU.
} 
Djibouti, Eritreia, Etiópia, Ruanda, Somália e Uganda são classificados como não-livres, somando $44 \%$.

Assim como a África Oriental, a África Ocidental abarca 16 países, exprimindo um grau de liberdade maior que os países do oeste do continente. Desse conjunto, quatro países são considerados livres, representados por Benin, Cabo verde, Gana e Senegal, somando $25 \%$. Entre os parcialmente livres, encontra-se Burkina Faso, Costa do Marfim, Guiné, Guiné-Bissau, Libéria, Mali, Níger, Nigéria, Serra Leoa e Togo, em um total de $62,5 \%$. Nesse universo, é fundamental destacar o papel exercido por Guiné-Bissau, que aumentou a sua classificação democrática de 2015 (5,5 pontos da Freedom House) para 2016 (5,0 pontos), mudando o seu status de não-livre para livre. Por fim, somente Gâmbia e Mauritânia são considerados como não-livres (12,5\% do total), enfatizando-se a significativa mudança política que ocorreu em dezembro de 2016 em Gâmbia, na qual se observou uma alternância de poder com a derrota eleitoral de Yahya Jammeh, que estava no poder há 22 anos (RFI, 2016).

A última região que será analisada refere-se à África Central, que engloba nove países, nos quais somente o insular São Tomé e Príncipe é classificado como livre, e todos os outros, como não-livres, a saber: Angola, Camarões, Chade, Congo, Gabão, GuinéEquatorial, República Centro-Africana e República Democrática do Congo. Em síntese, o mapa da liberdade da África pode ser observado na figura abaixo, no qual fica evidente relação entre a questão regional (localização geográfica) e a democracia do continente.

Figura 9 - Liberdade na África (FREEDOM HOUSE, 2016)

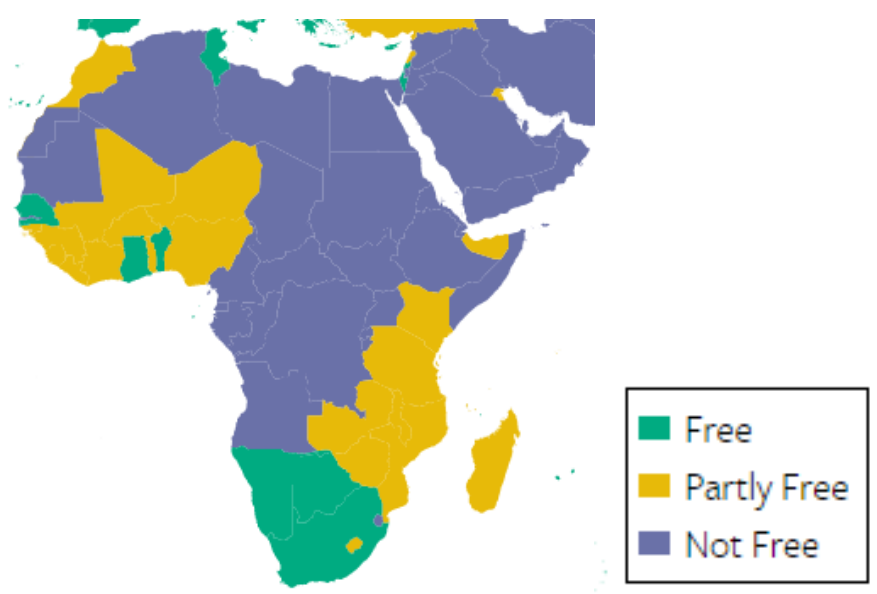

Fonte: FREEDOM HOUSE, 2016, s.p. 
É importante destacar um dado muito relevante identificado na coleta de dados dessa pesquisa. D acordo com as informações compiladas por meio do Polity IV (2016) e da Freedom House (2016), entre 1989 e 2016, dos 54 países que atualmente compõem a África ${ }^{23}, 53$ deles obtiveram um aumento no seu grau de democratização ${ }^{24}$. Esse dado é surpreendente porque, mesmo ainda se encontrando imerso em regimes ditatoriais que perduram por décadas, mesmo tendo perpassado por guerras civis e conflitos interregionais de profunda devastação e mesmo apresentando $63 \%$ dos seus países classificados como parcialmente livres ou não-livres ${ }^{25}$, a África exprimiu no pós-Guerra Fria um expressivo salto democrático e aumento de governança que ainda é subestimado e pouco estudado pela comunidade acadêmica internacional. Em síntese, tem-se que o indicador relacionado à localização geográfica se apresenta importante para compreender a democracia dos PALOP porque contextualiza o fato de que esses países lusófonos se encontram em uma região na qual a democracia ainda se apresenta como um fenômeno contemporâneo (há aproximadamente de 25 anos).

\section{Domínio português (colonização portuguesa):}

\section{Colonização e democracia: as conexões entre potência colonizadora e transição democrática no continente africano}

Para compreender os desdobramentos da democracia na África, é essencial analisar a trajetória histórica e o conjunto de fatores domésticos e externos que formaram a sociedade, economia e política de cada país. A obra "Democratization in Africa: African views, African voices" foi realizada por meio de diversos painéis e editada por Kpundeh em 1992. Ela se apresenta como uma importante fonte de informação sobre importantes

\footnotetext{
${ }^{23}$ Este estudo utilizou a denominação da Organização das Nações Unidas, excluindo a Saara Ocidental do conjunto dos países africanos. A análise dos dados foi realizada por meio de uma tabela de construção própria que compilou informações tanto os da Freedom House quanto do Polity IV (ver Anexo A).

${ }^{24}$ Dos 54 países do continente Africano, somente o Gâmbia apresentou um declínio da sua democracia de 1990 a 2016. O aumento da democratização não significa que os países tenham se tornado democráticos, ou seja, tenham concluído a transição para a democracia. Os ganhos democráticos foram diferentes nos variados países do continente africano. É importante destacar que 10 países, a saber: Burkina Faso, Congo, Egito, Lesoto, Marrocos, Nigéria, Suazilândia, Sudão, Uganda e Zimbábue, foram mais democráticos nas décadas de 1960, 1970 ou 1980, sofrendo uma importante queda da democracia no final da década de 1990. Conforme dito anteriormente, desse período até 2016, todos eles sofreram algum aumento da sua democratização.

${ }^{25}$ Em 2016, dos 54 países africanos, 23 são classificados como não-livres, 21 como parcialmente livres e somente 10 são classificados como livres.
} 
questões africanas da contemporaneidade com os seus maiores especialistas. No painel "Colonial Legacy and Democratic Development in African Societies", um dos seus principais resultados pautou-se no fato de que o legado colonial consiste em uma variável fundamental para explicar a deterioração das instituições democráticas no período pósindependência africano.

Um dos principais argumentos apontados pelos participantes situa-se no fato de que, por retirar o poder de auto-governança dos povos africanos dominados, o colonialismo foi fundamentalmente um fenômeno ditatorial. Nesse contexto, os colonizadores não ensinaram e não aplicaram às suas colônias os valores e princípios democráticos. O legado autocrático imbuído nos recém-formados Estados africanos ganhou novos aspectos no cenário que se delineava após as suas independências, dificultando os processos de transição democrática que começaram a ocorrer nos anos subsequentes. Outra premissa importante abordada situa-se no fato de que, atualmente, muitas dessas mesmas potências que colonizaram a África de maneira ditatorial, demandam do continente uma democratização rápida e eficiente, a saber:

Former colonial rulers are now showing little patience or understanding about African politics, largely because of Africa's declining strategic importance in world politics in recent years, forgetting that they were the ones who took away African's dignity and self-respect, "maintaining they were too incompetent to understand their own rights". It was also argued by many participants that colonialism had destroyed indigenous democratic values and institutions without building stable replacements (KPUNDEH, 1992, p. 07).

Após compreender a conexão existente entre colonialismo e democratização, é importante analisar a correlação entre a democracia na África e a origem da potência colonizadora. Dessa forma, utilizando-se dos dados da Fredom House, foi realizado no âmbito desta tese um breve estudo comparando esses dois fatores, conforme será observado a seguir.

\section{Relação entre democracia e potência colonizadora}

Ao se realizar uma análise sobre a correlação entre democratização e potência colonizadora, tem-se com resultado os seguintes dados: 


\section{a) Colonização Francesa ${ }^{26}$ :}

De acordo com os dados da Freedom House (2016), dos 20 países africanos colonizados pela França, três são considerados livres (15\%), nove parcialmente livres (45\%) e oito são identificados como não livres (40\%), a saber:

Tabela 5 - Classificação da liberdade nas ex-colônias francesas na África

\begin{tabular}{|l|l|}
\hline \multicolumn{1}{|c|}{ País } & \multicolumn{1}{c|}{$\begin{array}{c}\text { Classificação da } \\
\text { liberdade }\end{array}$} \\
\hline Argélia & Não-livre \\
\hline Benin & Livre \\
\hline Burkina Faso & Parcialmente livre \\
\hline Camarões & Não-livre \\
\hline Chade & Não-livre \\
\hline Comores & Parcialmente livre \\
\hline Congo & Não-livre \\
\hline Costa do Marfim & Parcialmente livre \\
\hline Djibuti & Não-livre \\
\hline Gabão & Não-livre \\
\hline Guiné & Parcialmente livre \\
\hline Madagascar & Parcialmente livre \\
\hline Mali & Parcialmente livre \\
\hline Marrocos & Parcialmente livre \\
\hline Mauritânia & Não-livre \\
\hline Níger & Parcialmente livre \\
\hline República Centro-Africana & Não-livre \\
\hline Senegal & Livre \\
\hline Togo & Parcialmente livre \\
\hline Tunísia & Livre \\
\hline
\end{tabular}

Fonte: Tabela elaborada pela autora baseada nos dados da Freedom in the World. FREEDOM HOUSE, 2016.

\footnotetext{
${ }^{26}$ Os territórios de tutela única dos Camarões e Togo (GARDINIER, 1964) serão considerados para esta estatística como colônias francesas, apesar de primeiramente terem feito parte da colonização alemã e, após a Primeira Guerra Mundial, terem sido territórios divididos entre franceses e britânicos. Posteriormente, serão analisados novamente como ex-colônias alemãs.
} 
Desse universo, infere-se que a colonização francesa gerou um cenário autocrático no qual, mesmo após as liberalizações política e econômica de 1990, as suas ex-colônias ainda não conseguiram instaurar a democracia como o regime político vigente. Contudo, é necessário escrutinizar esses dados com mais atenção para extrair um conteúdo importante e bastante explicativo nesse conjunto específico. Os países que pertenciam à África Equatorial Francesa (Chade, Congo, Gabão e República CentroAfricana) são todos classificados como não-livres. Já os países da África Ocidental Francesa são identificados majoritariamente como livres (Benin e Senegal) ou parcialmente livres (Burkina Faso, Costa do Marfim, Guiné, Mali, Níger, Senegal), sendo somente a Mauritânia considerada como não-livre. Esses dados sugerem que, devido a questões idiossincráticas, a colonização da França na África pode não ter seguido um padrão único em todo o continente africano, podendo ter adquirido características regionais singulares que decorreram da organização histórica e social de cada território. São necessários estudos futuros para provarem e aprofundarem essas questões, mas certamente a probabilidade de que os resultados apresentados não sejam uma simples coincidência é muito alta.

\section{b) Colonização Britânica ${ }^{27}$ :}

A colonização britânica na África ocorreu efetivamente em 18 países. Desse universo, quatro são considerados livres (22\%), nove como parcialmente livres (50\%) e cinco como não-livres (27\%), conforme se observa abaixo:

\footnotetext{
${ }^{27}$ No âmbito deste estudo não foram consideradas ex-colônias britânicas Camarões (Francês), Eritreia e Somália (Italiano). A Tanzânia será considerada nesta parte como colônia britânica, mas será estudada novamente na abordagem referente à colonização alemã.
} 
Tabela 6 - Classificação da liberdade nas ex-colônias britânicas na África

\begin{tabular}{|l|l|}
\hline \multicolumn{1}{|c|}{ País } & Classificação da liberdade \\
\hline África do Sul & Livre \\
\hline Botswana & Livre \\
\hline Egito & Não-livre \\
\hline Gâmbia & Não-livre \\
\hline Gana & Livre \\
\hline Lesoto & Parcialmente livre \\
\hline Malawi & Parcialmente livre \\
\hline Maurícia & Livre \\
\hline Nigéria & Parcialmente livre \\
\hline Quênia & Parcialmente livre \\
\hline Serra Leoa & Parcialmente livre \\
\hline Seychelles & Parcialmente livre \\
\hline Suazilândia & Não-livre \\
\hline Sudão & Não-livre \\
\hline Tanzânia & Parcialmente livre \\
\hline Uganda & Não-livre \\
\hline Zâmbia & Parcialmente livre \\
\hline Zimbábue & Parcialmente livre \\
\hline
\end{tabular}

Fonte: Tabela elaborada pela autora baseada nos dados da Freedom in the World. FREEDOM HOUSE, 2016.

Apesar das ex-colônias britânicas apresentarem um grau de democratização maior quando comparadas às ex-colônias francesas, observa-se nesse complexo universo o mesmo fenômeno relacionado à regionalização do sucesso ou insucesso das transições democráticas desses países. Isso se observa no fato de que todos os países da África Central Britânica (Malawi, Zâmbia e Zimbábue) são considerados parcialmente livres. Já os países da África Oriental Britânica apresentam Quênia e Tanzânia como parcialmente livres e Uganda como não-livre. O grau de liberdade nas ex-colônias inglesas se mostra maior na África Meridional Britânica, com dois países livres (África do Sul e Botswana), um país parcialmente livre, com a classificação de 3 pontos da Freedom House (considerado quase livre, ) e um país como não-livre (Suazilândia). Ao contrário do sul do 
continente africano, a África Ocidental Britânica é mais autocrática: dos quatro países que a compõem, somente Gana é considerada livre. Gâmbia é considerada não-livre e, Nigéria e Serra Leoa, como parcialmente livres.

Os dados apresentados sugerem que a análise regionalizada da colonização inglesa ajuda a explicar padrões de similaridades na conformação dos Estados que surgiram dos universos das suas ex-colônias. Assim como fora observado com o Império Francês na África, tem-se que a estruturação de uma análise pautada em um recorte regional das colonizações ocorridas no território africano pode resultar em um importante fator explicativo para pesquisas que serão porventura realizadas no futuro sobre o tema. Esse aspecto constitui uma contribuição desse artigo para a literatura sobre democratização na África, visto que grande parte dos estudos nessa temática não subdividem as colonizações de acordo com questões regionais, mas as enquadram como uma unidade de análise única tendo como referência a potência colonizadora. Ao desconsiderar o caráter regional da colonização, diversas questões apresentam maiores limitações no seu escopo explicativo, fazendo com que não se possa, em grande parte das vezes, correlacionar de maneira fidedigna outras variáveis ao processo de colonização.

\section{c) Colonização Portuguesa:}

Quando comparada às colonizações francesa e inglesa na África, a colonização portuguesa se apresenta pouco expressiva, abarcando cinco países: Angola e São Tomé e Príncipe na África Central, Moçambique na África Oriental e, finalmente, Cabo Verde e Guiné-Bissau na África Ocidental. Desse conjunto, conforme exposto anteriormente nesta tese, dois são considerados livres (40\%), dois são classificados como parcialmente livres (40\%) e um, como não-livre (20\%).

Tabela 7 - Classificação da liberdade nas ex-colônias portuguesas na África

\begin{tabular}{|l|l|}
\hline País & Classificação da liberdade \\
\hline Angola & Não-livre \\
\hline Cabo Verde & Livre \\
\hline Guiné-Bissau & Parcialmente livre \\
\hline Moçambique & Parcialmente livre \\
\hline São Tomé e Príncipe & Livre \\
\hline
\end{tabular}


Fonte: Tabela baseada nos dados da Freedom in the World. FREEDOM HOUSE, 2016.

Da mesma forma que fora observado na análise das colonizações francesa e britânica, a colonização portuguesa também apresenta um caráter de regionalização importante quando se observa que os PALOP insulares são classificados como livres enquanto os PALOP continentais são tidos como parcialmente-livre ou não-livres. Em termos comparativos, a colonização portuguesa se apresenta como a mais livre quando comparada às duas anteriores. Contudo, quando se excluem os PALOP insulares, ela se revela como a menos livre de todas.

\section{d) Colonização Alemã:}

A colonização alemã na África ocorreu de maneira muito singular, visto que depois da Primeira Guerra Mundial, muitas das suas ex-colônias passaram a ser tuteladas ou a pertencer a outras nações, a saber: Burundi e Ruanda foram integrados ao Império Belga, Camarões à França e à Grã-Bretanha, a Tanzânia à Grã-Bretanha, e a Namíbia, à África do Sul. Desse conjunto de seis países, somente um é considerado livre (17\%), dois são parcialmente livres (33\%) e três são tidos como não-livres (50\%). De acordo com esses dados, é possível observar que a maioria dos países que tiveram o início da sua colonização realizada pela Alemanha apresentou em 2016 uma cena doméstica de significativa autocracia.

Tabela 8 - Classificação da liberdade nas ex-colônias alemãs na África

\begin{tabular}{|l|l|}
\hline País & Classificação da liberdade \\
\hline Burundi & Não-livre \\
\hline Camarões & Não-livre \\
\hline Namíbia & Livre \\
\hline Ruanda & Não-livre \\
\hline Tanzânia & Parcialmente livre \\
\hline Togo & Parcialmente livre \\
\hline
\end{tabular}

Fonte: Tabela elaborada pela autora baseada nos dados da Freedom in the World. FREEDOM HOUSE, 2016. 


\section{e) Colonização Italiana:}

A colonização ou ocupação italiana na África se expressou por meio de três países: Eritreia, Líbia e Somália, nos quais todos se apresentam atualmente como nãolivres. Apesar da complexidade que abarca cada um desses casos, de uma maneira geral é possível correlacionar o fato de que os países que tiveram a presença italiana na África apresentam atualmente cenários profundamente autocráticos, conforme se observa a seguir:

Tabela 9 - Classificação da liberdade nas ex-colônias italianas na África

\begin{tabular}{|l|l|}
\hline País & Classificação de liberdade \\
\hline Eritreia & Não-livre \\
\hline Líbia & Não-livre \\
\hline Somália & Não-livre \\
\hline
\end{tabular}

Fonte: Tabela elaborada pela autora baseada nos dados da Freedom in the World. FREEDOM HOUSE, 2016.

\section{f) Colonização Belga:}

A colonização belga no continente africano se expressou por meio de três países: Burundi, República Democrática do Congo e Ruanda, sendo que todos eles são classificados como atualmente como não-livres. Outro fator importante situa-se no fato de que todos eles se localizam na mesma região geográfica, tendo compartilhado conflitos transfronteiriços, causando grande instabilidade na região da África Central.

\section{Tabela 10 - Classificação da liberdade nas ex-colônias belgas na África}

\begin{tabular}{|l|l|}
\hline País & Classificação de liberdade \\
\hline Burundi & Não-livre \\
\hline República Democrática do Congo & Não-livre \\
\hline Ruanda & Não-livre \\
\hline
\end{tabular}

Fonte: Tabela elaborada pela autora baseada nos dados da Freedom in the World. FREEDOM HOUSE, 2016. 


\section{g) Colonização Espanhola}

A breve análise da democracia na colonização espanhola na África foi à reduzida no presente estudo à Guiné Equatorial, que se encontra como não-livre. É importante destacar que o território do Saara Ocidental também é classificado pela Freedom House (2016) como não-livre.

Conforme exposto na análise da variável “domínio colonial”, foi possível notar que esse aspecto exerce uma influência significativa na democratização dos diferentes Estados do continente africano. Nesse cenário analítico, também é importante destacar a regionalização, que conforme exposto no tópico sobre a "localização geográfica", exerce um papel fundamental para uma compreensão histórica mais aprofundada sobre as transições democráticas na África. Nessas análises, foi possível identificar o peso dessas duas variáveis na cadeia causal proposta, e ao mesmo tempo, contextualizar as realidades dos PALOP aos desdobramentos democráticos observados no continente.

\section{Crescimento econômico:}

A relação entre crescimento econômico e democracia se apresenta como um tema bastante estudado na literatura sobre democratização. Lima e Gonçalves (2011) afirmam que o início desse debate se pautou na obra "Some social requisites for democracy: economic development and political legitimacy" de Lipset (1959), conforme se observa no excerto a seguir: A discussão sobre a existência de uma relação entre desempenho econômico e
regime político é antiga e se inicia com Lipset (1959), que argumenta ser o
regime democrático a etapa final de um processo de modernização social e
política dos países. Desenvolvimento causaria, portanto, a democracia. Tal
proposição, que se difundiu na literatura sob o epíteto de Teoria da
Modernização, deu vazão a uma ampla literatura empírica (LIMA;
GONÇALVES, 2011, P. 341).

Przeworski (2004) no artigo "Democracy and Economic Development" argumenta que as democracias são mais comuns em países ricos e menos presentes em 
países pobres ${ }^{28}$. Isso se explica devido às observações empíricas realizadas pelo autor, a saber:

Between 1950 and 1999, of the 1,335 annual observations of countries with per capita income under $\$ 1,000$, we observed only 142 years of democracy. Of the 880 annual observations of countries with incomes above $\$ 8,000$, only 147 years were spent under dictatorships. Indeed, if one takes per capita income alone, one will correctly predict 75 percent of the 5179 annual observations of regimes (PRZEWORSKI, 2004, p. 02).

Como uma das razões apresentadas para explicar essa premissa, o autor cita a teoria da modernização, na qual as democracias são mais prováveis de existirem em países economicamente mais desenvolvidos. Além disso, ele afirma que nos países mais estruturados economicamente, as chances de sobrevivência de uma democracia são maiores do que nos países que possuem um contexto econômico fragilizado. Considerando o cenário de conflitos armados vivenciado pelos PALOP continentais, que teve como consequência a instabilidade econômica antes e durante a democratização, compreende-se a importância que essa variável exerce para explicar o (relativo) insucesso das suas transições democráticas.

Além do crescimento econômico se caracterizar como uma das variáveis importantes para o crescimento e fortalecimento da democracia, muitos autores acreditam que a democracia fomenta a fortalece o crescimento econômico, formando um círculo virtuoso, a saber:

\section{Figura 10 - Círculo virtuoso entre crescimento econômico e democracia}

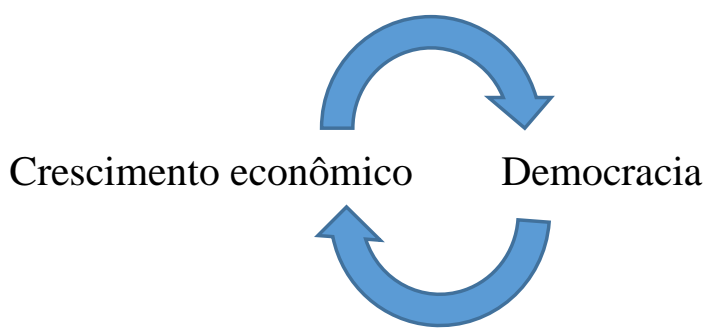

Fonte: Figura elaborada pela autora.

\footnotetext{
${ }^{28}$ Essa premissa também é compartilhada por outros autores, como Lipset (1961) na obra "Political Man".
} 
Ao analisar as 80 piores economias do mundo de 1963 a 2003, o Council of Foreign Relations (2003) descobriu que 77 delas pertenciam a países autocráticos. Da mesma forma, Lima e Gonçalves (2011) verificaram a relação entre variáveis econômicas e duração dos regimes democráticos ou autocráticos ao observarem um conjunto de 189 países no período de 1950 a 2005, chegando à conclusão de que "o regime democrático ao ser instaurado num país com maior PIB per capita e maior nível educacional tem maior sobrevivência que se instaurado num país sem estas características" (LIMA; GONÇALVES, 2011, p. 345). De acordo com a obra "Democratization in Africa: African views, African voices" (1992), o argumento de que as autocracias geram piores resultados econômicos é fortalecido por meio da afirmação: "The authoritarian state in Africa, which is a postindependence revival of the colonial state, corresponds to economic stagnation and disintegration" (KPUNDEH, 1992, p. 09).

Para Inglehart e Welzel (2009), é mais provável que o desenvolvimento econômico leve à democracia do que o contrário. De acordo com os autores, depois de alcançar determinado nível econômico,

Fifty years ago, the sociologist Seymour Martin Lipset pointed out that rich countries are much more likely than poor countries to be democracies. Although this claim was contested for many years, it has held up against repeated tests. The causal direction of the relationship has also been questioned: Are rich countries more likely to be democratic because democracy makes countries rich, or is development conducive to democracy? Today, it seems clear that the causality runs mainly from economic development to democratization. During early industrialization, authoritarian states are just as likely to attain high rates of growth as are democracies. But beyond a certain level of economic development, democracy becomes increasingly likely to emerge and survive. Thus, among the scores of countries that democratized around 1990, most were middle-income countries: almost all the high-income countries already were democracies, and few low-income countries made the transition. Moreover, among the countries that democratized between 1970 and 1990, democracy has survived in every country that made the transition when it was at the economic level of Argentina today or higher; among the countries that made the transition when they were below this level, democracy had an average life expectancy of only eight years (INGLEHART; WELZEL, 2009, P. 01).

A relação entre crescimento econômico e democracia ainda se apresenta como um tema constantemente muito estudado na literatura sobre democratização. Enquanto alguns autores consideram as inúmeras correlações já realizadas entre fatores econômicos e democracias/autocracias suficientes para estabelecer uma conexão causal relativamente 
robusta, outros acadêmicos acreditam que elas ainda se apresentam pouco fidedignas, podendo gerar conclusões espúrias.

Para Inglehart e Welzel (2009), o desenvolvimento econômico impulsiona o desenvolvimento social quando há uma mudança de comportamento da sociedade. Isso ocorre quando se observam dois fenômenos: a) as melhoras econômicas fomentam uma classe média expressiva, bem-educada e articulada que começa a pensar por si mesma e b) caso haja uma mudança de motivações e valores das pessoas.

$\mathrm{Na}$ presente tese de doutorado, tem-se como premissa o fato de que o crescimento econômico consiste em uma das variáveis que ajudam a explicar a estabilidade econômica, que por sua vez, pode influenciar significativamente o sucesso ou insucesso da transição para a democracia dos PALOP. Nesse contexto, a variável que será analisada a seguir aborda o papel do desenvolvimento social na supracitada cadeia causal.

\section{Desenvolvimento social:}

Inglehart e Welzel (2009) apresentam parte do debate baseado na temática de como o desenvolvimento social leva à democracia. Nesse escopo, afirmam que determinados contextos sociais e culturais são mais propícios para que a democracia surja e sobreviva. No estudo realizado pelo Council of Foreign Relations (2003), no qual foram analisadas as 80 piores economias do mundo nos últimos 40 anos, observou-se que, na dimensão do desenvolvimento do bem-estar social, exemplificado pela expectativa de vida, mortalidade infantil, alfabetização, entre outros fatores, os países democráticos obtiveram índices até $50 \%$ maiores do que os de caráter autoritário. Nesse cenário, a importância dessa variável é abordada no seguinte excerto: "if we cannot say that a "high" level of education is a sufficient condition for democracy, the available evidence does suggest that it comes close to being a necessary condition in the modern world" (COUNCIL OF FOREIGN RELATIONS, 2003, p. 80).

Pieters, Curzi, Olper e Swinnen (2016) realizaram uma importante revisão de literatura sobre o impacto da democratização na saúde dos cidadãos de países que realizaram a transição para a democracia. Eles afirmaram que correlações positivas entre 
democracia e indicadores como expectativa de vida e mortalidade infantil foram observados em diversos estudos, tais como o de Besley e Kudamatsu (2011) e o de Franco, Élvarez-Dardet e Ruiz (2004). Ao analisar os dados da sua própria investigação, os autores notaram que, entre os países que vivenciaram transições democráticas entre 1960 e 2010, as taxas de mortalidade infantil foram menores nos Estados democráticos em relação aos autocráticos, a saber:

Of 60 countries that underwent democratic transition in the study period, 33 met our inclusion criteria. We were able to construct good counterfactuals for 24 of these. On average, democratization reduced child mortality, and the effect increased over time. Significant reductions in child mortality were seen in nine (38\%) countries, with the average reduction 10 years after democratization being $13 \%$ [...] The effect of democratization, however, was stronger in countries with above average child mortality before transition than in countries with below average child mortality (PIETERS; CURZI; OLPER; SWINEN, 2016, p. 01).

Anckar (2002) afirma que há uma relação direta entre democracia e taxa de alfabetização e democracia e taxa de matrícula no ensino básico, conforme será analisado no tópico a seguir sobre insularidade e microestados. Ao verificar a relação entre IDH e democracia considerando dados obtidos de 146 países, Berggren (2012) afirma que os países mais democráticos apresentam maiores valores no seu IDH, a saber:

Figura 11 - Correlação cross-seccional entre democracia e IDH no período de 2005

\section{a 2010 (BERGGREN, 2012)}

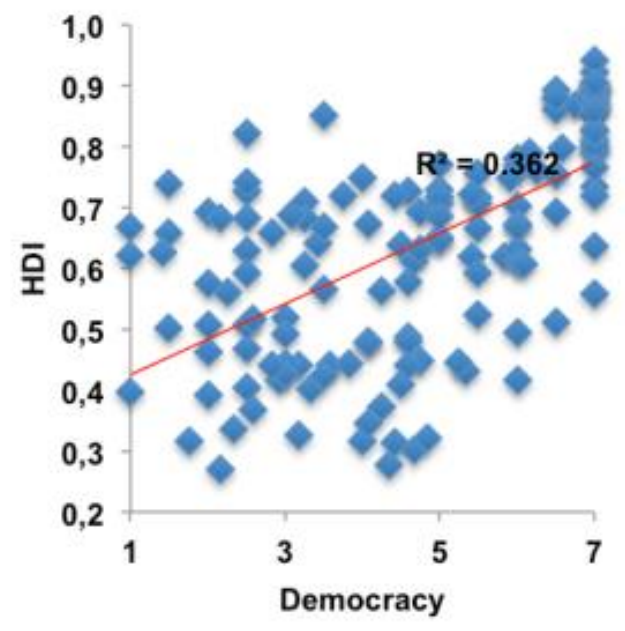

*É importante destacar que, para fins analíticos do gráfico elaborado, os valores da Freedom House encontram-se invertidos, ou seja, 1 representa os países menos democráticos e 7, os mais democráticos. Fonte: BERGRREN, 2012, p. 15. 
Além dessa descoberta, o autor confirmou a hipótese de que a democracia é mais importante para o desenvolvimento social do que o crescimento econômico. Dessa forma, o corrobora com a teoria do desenvolvimento como liberdade de Amartya Sen (1999), visto que, na sua concepção, liberdade e desenvolvimento humano são compatíveis e inter-relacionados. Outro dado importante obtido na referida investigação aborda o fato de que os países que realizaram a sua transição democrática entre 1990 e 2005 apresentaram taxas de crescimento do IDH significativamente maiores quando comparados aos outros países analisados no mesmo período (BERGGREN, 2012).

De acordo com a análise realizada pela autora nesta tese (ver Anexo C), a correlação entre IDH e democracia na África em 2016 também apresenta um resultado positivo, ou seja, os países mais democráticos denotam maiores valores no seu IDH (o índice varia de 0 a 1). Dos 54 países analisados, nenhum apresentou IDH considerado alto (acima de 0,800), 27 (50\%) denotaram valores médios (entre 0,500 e 0,799) e $27(50 \%)$ obtiveram valores baixos. É importante destacar, contudo, que entre os países que apresentaram um IDH intermediário, 15 (55,5\%) estão inseridos em uma faixa muito próxima ao valor baixo do referido índice (entre 0,500 e 0,600).

Além disso, dos 27 países classificados com um IDH médio, oito (30\%) são considerados livres (África do Sul, Botswana, Cabo Verde, Gana, Maurícia, Namíbia, São Tomé e Príncipe e Tunísia), nove (33\%) como parcialmente livres (Comores, Madagascar, Marrocos, Nigéria, Quênia, Seychelles, Tanzânia, Zâmbia e Zimbábue) e, finalmente, dez (37\%) são tidos como não-livres (Angola, Argélia, Camarões, Congo, Egito, Gabão, Guiné Equatorial, Líbia, Mauritânia e Suazilândia). Já no grupo dos países com um IDH baixo, somente dois (7\%) são considerados livres (Benin e Senegal), enquanto 12 (45\%) são classificados como parcialmente livres (Burkina Faso, Costa do Marfim, Guiné, Guiné-Bissau, Lesoto, Libéria, Malawi, Mali, Moçambique, Níger, Serra Leoa e Togo) e 13 (48\%) são tidos como não-livres (Burundi, Chade, Djibouti, Eritreia, Etiópia, Gâmbia, República Centro-Africana, República Democrática do Congo, Ruanda, Somália, Sudão, Sudão do Sul e Uganda).

Considerando o debate apresentado, no âmbito da presente tese, os indicadores utilizados para analisar o desenvolvimento social dos PALOP nos próximos capítulos serão: a) expectativa de vida, b) mortalidade infantil, c) taxas de alfabetização, d) taxas de matrícula no ensino básico (primary school enrolment) e e) IDH. 
É fundamental destacar as considerações sobre a complexidade desse campo de estudos realizadas por Besley e Kudamatsu (2011). Na concepção dos autores, as correlações existentes entre democracia e diversos fatores sociais não necessariamente exprimem efeitos causais, conforme se observa na afirmação a seguir:

\begin{abstract}
Even if correlations between democracy and outcome measures can be found, there is an overriding difficulty of interpreting them as causal effects. Whether democracy matters, per se, or simply serves as a proxy for societal and political development presents a difficult problem for research in this area (BESLEY; KUDAMATSU, 2011, p. 313).
\end{abstract}

Por meio dos argumentos expostos, foi possível compreender que o desenvolvimento social, assim como o crescimento econômico, se apresenta como uma variável importante que pode explicar o êxito ou insucesso da democratização de determinado país. Na continuação da análise das variáveis presentes na cadeia causal deste estudo, o tópico a seguir abordará a questão da insularidade e dos microestados visà-vis as suas dinâmicas econômicas e sociais.

\title{
5. Insularidade e microestado:
}

Uma parte significativa da literatura sobre democratização afirma que os países insulares, notadamente os pequenos Estados, tendem a ser mais democráticos que os países continentais. Isso pode ser explicado por questões como o fato de que, recorrentemente, os países insulares apresentam escassez de recursos naturais, um território menor e bem definido, uma população reduzida e maior governabilidade administrativa e flexibilidade política para a implantação de políticas desenvolvimentistas, tais como a diplomacia dos pequenos Estados.

De acordo com a teoria da escolha pública (Public Choice Theory), quanto maior for uma entidade política, menores serão os incentivos de participação dos cidadãos na sua estrutura democrática. Nesse ínterim, Von Laer (2015) afirma que a democracia deve ser analisada considerando o seu tamanho. Para o autor, os pequenos Estados apresentam um conjunto de características específicas que lhes conferem vantagens quando comparados às grandes democracias, a saber: a) os cidadãos conhecem (muitas vezes pessoalmente) os seus governantes, b) ofeedback dos dirigentes para a sociedade é maior, 
c) os grupos de pressão conseguem se articular de maneira mais efetiva, d) os mecanismos de feedback disponíveis aos cidadãos são mais efetivos, proporcionando uma resposta da população em relação ao governo mais rápida e clara, e) as condições culturais diversas são melhor acomodadas dentro da sociedade e f) as visões divergentes possuem maiores chances de serem consideradas.

Apesar de reconhecer que o tamanho dos países não se constitua como o único componente que influencia o seu comportamento institucional e social, o referido autor destaca que essa variável se mostra importante para explicar as dinâmicas democráticas dos pequenos Estados, conforme se observa no excerto:

\begin{abstract}
Of course, size is not the only one component that play a role within the institutional web that makes-up society. Nevertheless, I maintain that the complexities of the world we live in might be better handled by smaller institutions than by larger ones, due to their responsiveness, their agility, and the increased potential for experimentation (VON LAER, 2015, p. 01)
\end{abstract}

Anckar (2002) afirma existir uma forte correlação entre tamanho/insularidade e democracia. Para o autor, a teoria da modernização (que será abordada em alguns aspectos deste estudo por meio do crescimento econômico) e o desenvolvimento social (pautado nas taxas de alfabetização e aspectos sociais da modernização) nem sempre conseguem responder aos questionamentos de por que alguns países se tornam democráticos e outros não. Além disso, para o autor, o tipo de colonização também não explica de maneira satisfatória a evolução da democracia em países pequenos e/ou insulares. Nesses cenários, ele afirma ser importante considerar a variável relacionada ao tamanho dos Estados ao fato de eles serem insulares ou não para compreender os fatores que influenciam a sua democracia.

Para o autor, os microestados possuem menos de um milhão de habitantes. Já os Estados insulares são definidos por serem formados por ilhas ou partes de uma ilha. Ao a democracia em países utilizando os dados da Freedom House de 1999, ele descobriu que $72 \%$ dos microestados eram livres, $12 \%$ parcialmente livres e $16 \%$ eram considerados "não-livres". No âmbito dos Estados insulares, ele observou novamente valores muito elevados de democracia: $71 \%$ eram livres, $21 \%$ parcialmente livres e $8 \%$ "não-livres". Por fim, ao combinar essas duas variáveis e analisar os microestados insulares, notou que esse número se mostrava ainda mais expressivo, com $80 \%$ dos países, livres, $13 \%$ como 
parcialmente livres e 7\% como "não-livres". Um dos motivos que explicam resultados tão semelhantes se refere ao fato de que a maioria dos estados insulares é pequena, o que faz com que o autor chegue à seguinte afirmação: "a reasonable conclusion is perhaps that size makes a difference and that insularity adds to this difference, although not much" (ANCKAR, 2002, p. 378). A significativa conexão entre essas duas características explica a escolha de uma variável híbrida para a cadeia causal da tese, agregando tanto a questão do tamanho quanto a insularidade dos PALOP.

$\mathrm{Na}$ África, dos 54 países analisados pela autora nesta tese (ver Anexo B), seis são insulares e quatro são considerados microestados insulares29. Entre os insulares, três são classificados como livres (Cabo Verde, Maurícia e São Tomé e Príncipe) e três como parcialmente livres (Comores, Madagascar e Seychelles), sendo as suas classificações muito próximas à dos países livres. Já no âmbito dos microestados insulares, dois são classificados como livres (Cabo Verde e São Tomé e Príncipe) e dois como parcialmente livres (Comores e Seychelles). Nesse ínterim, observa-se que no caso africano, a insularidade apresenta uma grande correlação com o êxito democrático, destacando-se também uma questão relevante do isolacionismo: ele evita a externalidade negativa de conflitos armados transfronteiriços, que são recorrentes em determinados espaços do continente. Alguns autores acreditam que a saída para o mar também se constitua uma variável que possui grande correlação com a democracia. De acordo com os dados presentes no Anexo B, observa-se que entre os 16 (30\%) países africanos que não possuem saída para o mar, somente um (6\%) é classificado como livre (Botswana), enquanto sete (44\%) são considerados parcialmente livres e oito (50\%), como não-livres. Dos 38 (70\%) países que possuem saída para o mar, nove são considerados livres (24\%), 14 são tidos como parcialmente livres (37\%) e, por fim, 15 (39\%) países são classificados como não-livres. A análise desses dados permite, mais uma vez, identificar uma significativa correlação entre democracia e localização geográfica no cenário africano.

O estudo de Anckar (2002) permitiu observar que Cabo Verde e São Tomé e Príncipe, por serem microestados insulares, encontram-se em um contexto no qual a probabilidade de sucesso da implantação da democracia mostra-se mais expressiva. É

29 De acordo com os dados do Banco Mundial (2015a), a população de Cabo Verde é de 520.502 habitantes, a de Comoros é de 788.474 habitantes, Madagascar é de 1.262.605 habitantes, Maurícia, Seychelles 92.900 habitantes, e finalmente, São Tomé e Príncipe apresenta 190.344 habitantes. Dessa forma, por apresentarem menos de um milhão de habitantes, Cabo Verde, Comoros, Seychelles e São Tomé e Príncipe são considerados microestados, de acordo com a definição de Anckar (2002). 
importante destacar, conforme se observa na tabela abaixo, que ser um microestado e/ou ser insular não são determinantes para o sucesso democrático de um país. Como exemplo, o autor cita o caso de países como Bahrein, que possui essas características e, mesmo assim, se apresenta autocrático. Por esse motivo, cada variável apresentada nesse estudo desse ser analisada de maneira interconectada, explicitando o peso que cada uma exerce em cenários específicos. A tabela elaborada por Anckar (2002) demonstrando o seu supracitado estudo pode ser observada a seguir:

\section{Tabela 11 - Freedom House ratings of micro-states, island states and small island states compared with other states: a summary view (ANCKAR, 2002)}

\begin{tabular}{|c|c|c|c|}
\hline & Free States & Partly Free States & Not Free States \\
\hline Micro-states (N) & 31 & 5 & 7 \\
\hline Micro-states (\%) & 72 & 12 & 16 \\
\hline Other states $(\mathrm{N})$ & 52 & 55 & 42 \\
\hline Other states (\%) & 35 & 37 & 28 \\
\hline Island states $(\mathrm{N})$ & 34 & 10 & 4 \\
\hline Island states (\%) & 71 & 21 & 8 \\
\hline Other states (N) & 51 & 49 & 44 \\
\hline Other states (\%) & 35 & 34 & 31 \\
\hline Small island states (N) & 23 & 4 & 2 \\
\hline Small island states (\%) & 80 & 13 & 7 \\
\hline Other states $(\mathrm{N})$ & 62 & 54 & 47 \\
\hline Other states (\%) & 38 & 33 & 29 \\
\hline
\end{tabular}

Fonte: ANCKAR, 2002, p. 377.

Ao analisar a relação entre pequenos Estados e desenvolvimento econômico, ANCKAR (2002) observou que entre os países mais ricos, dos sete Estados analisados, cinco são considerados livres e dois, como "não-livres" (Brunei e Bahrein). Entretanto, ao contrário do que se nota em países que não são microestados insulares, neste último grupo não houve grande alteração nos níveis de democracia ao se analisar os países de renda média e baixa. Dos 14 microestados insulares de renda média, 11 eram democracias. De acordo com o estudo utilizado por Anckar (2002), entre os países de renda média que não são microestados insulares, menos de $50 \%$ eram democráticos (26 Estados de um conjunto de 58). Já no grupo dos oito microestados insulares mais pobres, seis eram democráticos. No universo dos outros 69 países mais pobres do mundo, somente sete são classificados como democráticos. Para o autor, os diferentes resultados entre desenvolvimento econômico e democracia são explicados primordialmente por meio do 
tamanho dos Estados, a saber: "the obvious implication of this difference is that the relation between wealth and democracy is heavily influenced by differences in size: what is true of larger states is not necessarily true of small states" (ANCKAR, 2002, p. 380).

Tabela 12 - Wealth and democracy: small island states compared with other states (ANCKAR, 2002)

\begin{tabular}{lcrcc}
\hline & & \multicolumn{3}{c}{ Democracy standard } \\
\cline { 3 - 5 } & Income & Free & Partly Free & Not Free \\
\hline \multirow{3}{*}{ Small island states } & High & 5 & - & 2 \\
& Middle & 11 & 3 & - \\
\multirow{3}{*}{ Other states } & Low & 6 & 1 & 1 \\
& High & 31 & 2 & 3 \\
& Middle & 26 & 18 & 14 \\
& Low & 7 & 34 & 28 \\
\hline
\end{tabular}

Fonte: ANCKAR, 2002, p. 377.

Após analisar a relação entre renda, democracia e microestados insulares, Anckar (2002) finaliza o seu estudo considerando aspectos referentes ao desenvolvimento social. Conforme demonstrado no tópico anterior, tem-se que, ao analisar o conjunto de países do mundo, há uma relação direta entre democracia e indicadores sociais, tais como taxas de alfabetização. Ao utilizar o estudo de Axel Hadenius, o autor afirma que, entre os países mais alfabetizados, $77 \%$ são democráticos. Já nos países com uma taxa intermediária de alfabetização, somente $24 \%$ são democracias, sendo que esse número diminui ainda mais entre os países pouco alfabetizando, que totalizam $18 \%$ de democracias. Todavia, assim como fora observado com o crescimento econômico, o comportamento dos microestados insulares também foi diferente do observado dos outros países do mundo no âmbito social. Nesse cenário, $86 \%$ dos microestados insulares com as maiores taxas de alfabetização são democráticos. Já os microestados insulares com uma taxa média de alfabetização intermediária apresentam $57 \%$ de democracias, sendo que, os que apresentam os valores mais baixos, são $66 \%$ democráticos. É importante destacar que, do conjunto de 29 microestados insulares analisados, 16 se encontram no grupo com as maiores taxas de alfabetização e somente seis no grupo com os menores valores para esse índice. Os valores demonstrados pelo estudo encontram-se na tabela abaixo. Em síntese, o autor sumariza a relação entre microestados insulares, democracia e taxa de alfabetização no seguinte excerto: 
On the one hand, concerning the tendency of high literacy states to cultivate democratic standards, small island states and other states perform about equally well. However, when it comes to medium and low literacy states, a majority of the small island states remains in the democracy category, whereas the vast majority of other states are non-democracies. Again, therefore, size performs as an intervening variable that distorts the otherwise distinct and linear-like association between modernization and democracy (ANCKAR, 2002, p. 382)

Tabela 13 - Literacy and democracy: small island states compared with other states (ANCKAR, 2002)

\begin{tabular}{lccc}
\hline & Literacy rate & Democracies & Others \\
\hline \multirow{3}{*}{ Small island states } & High & 14 & 2 \\
& Medium & 4 & 3 \\
\multirow{3}{*}{ Other states } & Low & 4 & 2 \\
& High & 50 & 17 \\
& Medium & 5 & 26 \\
& Low & 9 & 56 \\
\hline
\end{tabular}

Fonte: ANCKAR, 2002, p. 381.

O autor ainda ressalta que é importante destacar que, nos microestados insulares, as taxas de matrícula no ensino básico são de $92 \%$, enquanto esses valores se apresentam em $62 \%$ na África Subsaariana, 85\% no Oriente Médio e Norte da África, 83\% na África Central, $84 \%$ no Sudeste Asiático e no Pacífico, 87\% nas Américas e 95\% na Europa. O fato dos microestados insulares apresentarem esses dados inferiores somente em relação à Europa explicam as maiores taxas de alfabetização nos seus territórios (ANCKAR, 2002). Como foi possível observar na análise desse tópico, os microestados e os Estados insulares possuem vantagens comparativas e possuem uma "in-built capacity for resourcefulness, structural openness and rapid policy development that fosters economic strength and sustainability" (ANCKAR, 2000, p. 378). Dessa forma, essa variável configura-se como um dos principais fatores explicativos para o sucesso ou insucesso da democratização nos PALOP. 


\section{Direitos políticos e liberdades civis:}

No presente trabalho, a importância dos direitos políticos e das liberdades civis para a democracia foi mencionada na revisão de literatura do Capítulo 1. Dessa forma, observa-se que eles são analisados na cadeia causal de acordo com o "procedural mínimo" abordado por Robert Dahl (1971). Além disso, indicadores como Freedom House, Polity IV e V-DEM serão importantes para fornecer aspectos importantes para a compreensão das liberdades civis e dos direitos políticos de cada um dos PALOP em perspectiva longitudinal. Mais uma vez, é importante destacar as oito condições do "procedural mínimo", a saber: a) liberdade para formar e se juntar a organizações; b) liberdade de expressão; c) direito ao voto; d) elegibilidade para cargos públicos; e) direito dos líderes políticos de competirem por apoio; f) fontes alternativas de informação; g) eleições livres e justas e h) instituições que possam elaborar políticas governamentais.

\section{Recursos naturais:}

A presença de recursos naturais é considerada por muitos autores como um problema para a democratização. Fortna e Huang (2009) realizaram um amplo estudo relacionando a democracia e inúmeras variáveis domésticas, chegando à conclusão de que países que são grandes exportadores de petróleo possuem chances muito mais reduzidas de terem sucesso na sua democratização. Acemoglu e Robinson (2013) defendem esse argumento afirmando haver uma significativa conexão entre ambas as variáveis, notadamente no fato de que a presença de petróleo pode influenciar as instituições políticas e a economia de determinado país. Os autores utilizam para a sua investigação as obras "Does Oil Hinder Democracy?”, de Michael Ross (2001), que analisou a relação entre democracia e recursos naturais em âmbito mundial e "Resource Wealth and Political Regimes in Africa”, de Nathan Jensen and Leonard Wantchekon (2004), que avaliaram a dimensão dessas duas variáveis no contexto africano. Como resultado esses trabalhos revelaram uma correlação negativa entre a abundância de recursos naturais e democracia, conforme se observa a seguir:

Both papers showed that different measures of natural resource abundance or importance in the economy were negatively correlated with how democratic a country was. Greater resource wealth, less democratic was the resounding 
message of these papers that became conventional wisdom in political science (ACEMOGLU; ROBINSON, 2013, s.p.).

Ao citar o estudo de Ross (2001), que englobou 113 países entre 1971 e 1997, Moore (2001) chegou a três conclusões:

1. Exporting oil is strongly associated with authoritarian rule;

2. This relationship is not limited to the Middle East, but worldwide and

3. Enjoyment of other types of 'concentrated' mineral exports has similar anti-democratic effects, while ('dispersed') agricultural exports do not" (MOORE, 2001, s.p.).

De acordo com o Natural Resource Governance Institute (2015), os recursos naturais podem diminuir a necessidade de impostos e, consequentemente, a accountability dos governantes em relação à população. Para o Governance and Development Review (2016), esse cenário de fortalecimento das forças governamentais também pode fazer com que os efeitos sociais da modernização não sejam implantados. Como exemplos, são mencionados os casos da Venezuela e da Líbia, a saber "There are some excellent country case studies supporting the notion that oil wealth is politically corrosive - for example, Karl (1997) on Venezuela, and Vanderwalle (1998) on Libya (GOVERNANCE AND DEVELOPMENT REVIEW, 2016, s.p.).”

Na concepção do IDEA (2016), a significativa presença de recursos naturais, como petróleo e gás natural, em países permeados por fracas estruturas democráticas pode fomentar corrupção, conflitos sociais, degradação ambiental e uma performance econômica ruim (doença holandesa). Contudo, em cenários nos quais esses recursos são bem aplicados utilizando-se de acordos democráticos, o retorno financeiro da produção desses recursos naturais pode resultar em desenvolvimento econômico e social, conforme observado em Botswana, Chile e Noruega.

Por fomentarem uma maior independência financeira do país, os recursos naturais os deixam menos vulneráveis às pressões internacionais votadas para a realização de mudanças democráticas. Alguns autores argumentam que essa realidade se desdobrou em Angola depois que o país começou a se recuperar da guerra civil. No contexto da presente tese, observa-se que os PALOP insulares, por não terem recursos naturais, apresentam mais uma vantagem no processo de democratização quando comparados à 
Angola, que possui em seu território uma significativa quantidade de petróleo. Destarte, essa pode ser uma das variáveis fundamentais que explicam o fato de Angola se encontrar atualmente como o mais autocrático dos PALOP.

\section{Diversidade étnica:}

A diversidade étnica apresenta-se como uma variável importante que ajuda a explicar o sucesso ou insucesso da democratização de determinado país. Alguns autores acreditam que, quanto mais homogênea for uma sociedade, maior será a sua harmonia social. Para Fish e Kroenig (2006), isso ocorre porque a maior parte dos acadêmicos acredita que existe uma alta probabilidade da diversidade étnica causar conflitos civis. Nesse contexto, citam a afirmação de David Welsh sobre o tema: "establishing and sustaining democratic institutions in ethnically divided societies is a difficult task" (FISH; KROENIG, 2006, p. 828). Além de Welsh, eles apontam o estudo de Gabriel Almond, que afirma que quanto maior for fragmentação étnica, maiores serão as chances de confrontos domésticos. Contudo, autores como Fearon e Laitin acreditam que a diversidade étnica não fomenta uma predisposição das sociedades ao conflito. Para eles, fatores geográficos e físicos, tais como relevo montanhoso de um país e tamanho da sua população apresentam-se como mais relevantes para explicar as guerras internas (FISH; KROENIG, 2006).

Ao testarem o conjunto de países ex-comunistas entre 1991 e 2004, Fish e Kroenig (2006) descobriram que as sociedades mais diversas etnicamente são menos democráticas, ressaltando que a heterogeneidade social não necessariamente coloca a democracia em risco. Beissinger (2008) também afirma que a visão preponderante na Ciência Política é a de que a diversidade étnica se configura como uma barreira para a democracia. Como exemplos, ele cita Robert Dahl, que afirma que altos níveis de diversidade étnica diminuem a probabilidade do sucesso democrático, primordialmente em locais nos quais um grupo dominante tem a possibilidade de chegar ao poder. Por sua vez, Fortna e Huang (2009) demonstram em seu estudo que a democracia é menos provável tanto em Estados muito heterogêneos quanto naqueles muito homogêneos. Para as autoras, os países que se encontram em um contexto intermediário de diversidade étnica são os possuem maiores chances de sucesso na sua democratização. Beissinger 
(2008) também afirma que, para alguns autores, há um universo de questões domésticas relacionadas à grande diversidade étnica, tais como intolerância, inclinação ao militarismo, violência e, casos específicos, até mesmo o genocídio.

No escopo do estudo realizado na presente tese, tem-se a diversidade étnica como uma variável importante porque, ao explicar parte dos obstáculos democráticos perpassados pelos PALOP continentais após 1990, conecta-se intimamente à configuração dos seus conflitos civis. Além disso, é importante destacar o caráter pouco polarizado e conflituoso dos PALOP insulares, que se constituíam em ilhas inabitadas no momento da chegada dos portugueses no século XV. No escopo dessa variável, é possível obter respostas essenciais que ajudam a entender o sucesso e insucesso dos PALOP, conforme será analisado no capítulo a seguir.

\section{Conflitos armados: Guerras de independência e guerras civis}

Os conflitos armados são essenciais para explicar a estabilidade social, política e econômica de uma sociedade, exprimindo um conjunto de externalidades negativas que afetam direta ou indiretamente o sucesso da democratização. Autores como Fish e Kroenig (2006) apresentam estudos que revelam que conflitos civis podem se apresentar como um fenômeno que complica o processo de democratização.

Soderberg e Ohlson (2003) afirmam que guerras civis e conflitos domésticos possuem maior probabilidade de ocorrer em países que se encontram em um estágio democrático intermediário, ou seja, que não são nem autocracias nem democracias plenas. Já Fish e Kroenig (2006) acreditam que o tamanho da população de um Estado pode afetar a probabilidade de conflitos internos, tendo em vista que uma grande população dificulta o controle do governo central, facilitando também o recrutamento de forças rebeldes. Mais uma vez, esse fator confere uma vantagem aos PALOP insulares, que possuem uma população muito mais reduzida do que os PALOP continentais. Rich (2008) afirma que o tamanho territorial de um Estado também pode estar correlacionado com a ocorrência de conflitos domésticos. Nesse ínterim, afirma que nos microestados observa-se uma pequena quantidade de conflitos que efetivamente se tornaram guerras civis. 
Fortna e Huang (2009) realizaram um amplo estudo sobre o papel de diversas variáveis domésticas em países que iniciaram o seu processo de democratização após conflitos civis. Nesse trabalho, descobriram que a democratização tinha menores chances de sucesso em locais nos quais os conflitos ocorreram baseados em questões étnicas. É importante destacar que, ao analisarem a literatura sobre a mudança para a democracia depois de guerras domésticas, as autoras observaram que esse campo de estudos é incipiente e apresenta resultados muito discrepantes, formando um "puzzle" que ainda precisa ser melhor estudado. Enquanto alguns autores dizem que os conflitos impulsionam a democracia, outros dizem que eles causam obstáculos à sua implantação. É necessário realizar mais trabalhos não somente quantitativos, mas também qualitativos para que seja possível identificar os principais efeitos dos conflitos armados para a democracia. Nesse contexto, o trabalho realizado na presente tese pode contribuir para essa literatura por meio da análise do processo de liberalização e transição democrática de países que perpassaram conflitos civis. Os dados mencionados nos próximos capítulos ajudarão a compreender o efeito que esses confrontos tiveram para a estabilidade social, política e econômica de Moçambique, Guiné-Bissau e Angola, resultando em diferentes níveis de (relativo) insucesso democracia liberal em cada um desses Estados.

\section{Perfil das elites políticas}

O perfil das elites políticas é fundamental para explicar o êxito da democratização. No Capítulo 1, essa variável foi analisada no contexto dos diferentes tipos de transição para a democracia. Por esse motivo, ela não será extensamente analisada nesse tópico.

Schmitter (2016) afirma que nas "real-existing democracies" (REDs)30, o papel das elites políticas é complexo. Durante a transição democrática, a atuação dessas elites é imprevisível, formando um cenário no qual tais atores políticos ganham maior autonomia para escolher as "novas regras do jogo" que permearão o regime que emergirá após esse período de incertezas. Dessa forma, o autor argumenta que, nos períodos de

30 Para o autor, as "real-existing democracies" (REDs) compõem as todas as democracias existentes na realidade do mundo atual. As REDs possuem imperfeições idiossincráticas em cada país, pois não conseguem responder completamente a todos os requisitos dos modelos ideais de democracia presentes no escopo teórico desse campo de estudos. 
transição política, as elites exercem maior importância do que nos períodos de estabilidade - tanto democrática quanto autocrática. Outro fator importante a ser destacado é o fato de que nessa mudança, as elites podem se encontrar divididas, aumentando a instabilidade doméstica por não se saber qual grupo conseguirá ascender ao poder. Contudo, seja na transição pactuada ou na transição imposta, observa-se uma grande continuidade na composição das elites políticas do novo regime político.

Nesse cenário, Koudawo (2001) afirma que as elites políticas de Cabo Verde foram mais "leais" ao projeto de democracia implatado no país do que as elites guineenses (KOUDAWO, 2001). De acordo com Veiga (2004), as elites políticas dos PALOP insulares estavam mais articuladas para iniciarem o processo de democratização do que as elites dos PALOP continentais, que se apresentavam mais resistentes às mudanças.

\section{Independência de Portugal}

A independência dos países que se configuravam como ex-colônias não se apresenta como uma variável que por si só impulsione a democratização de um país, a exemplo do observado com as variáveis anteriores. Embora muitos países africanos tenham tido a oportunidade de realizar algumas breves experiências democráticas no pósindependência, esse fenômeno não foi presenciado nas ex-colônias portuguesas na África (KOUDAWO, 2011). Contudo, para esse estudo, a referida variável se mostra muito importante porque aborda um aspecto histórico importante que ajuda a explicar o contexto da cadeia causal e os desdobramentos das outras variáveis independentes antecedentes. Isso ocorre porque ela marca um cenário no qual as ex-colônias portuguesas deixaram de fazer parte da ditadura de Portugal e iniciaram, já soberanas, os seus próprios governos autocráticos de partido único. Destarte, a independência de Portugal marca a transição de um governo colonial ditatorial para um governo de influência marxista também autocrático. 


\section{Repúblicas populares de influência soviética}

A variável referente à presença de repúblicas populares de influência soviética indica a implementação de governos autocráticos por todos os PALOP no período entre 1975 a 1990. Ela é importante porque faz com que a transição dos PALOP pertença a um grupo específico de países, composto por Estados africanos de caráter marxista que realizaram a sua mudança de regime político após o colapso soviético.

\section{Estabilidade social, política e econômica}

A estabilidade social, política e econômica consiste em uma variável muito complexa, pois agrega e combina, em maior ou menor grau, cada uma das variáveis independentes antecedentes apontadas na cadeia causal. Dessa forma, a estabilidade social, política e econômica abrange o contexto doméstico de cada PALOP demonstrando as relações longitudinais das estruturas sociais, políticas e econômicas de desses países até 1990. Nesse ínterim, essa variável sintetiza de maneira singular os desdobramentos de todas as outras variáveis expostas no estudo, fornecendo um arcabouço explicativo robusto e fidedigno. Na perspectiva de Przeworski (2004), o argumento de que a instabilidade política afeta o crescimento econômico pode ser identificado da seguinte maneira:

\footnotetext{
Not everyone will be surprised to learn that political regimes have no effect on average rates of growth of total income. One generally held view, made influential by Huntington (1968), is that what matters for economic development is political stability, rather than the 18 particular political institutions. Any system of political institutions promotes development as long as it maintains political order. The danger is "political instability" (PRZEWORSKI, 2004, p. 17).
}

Assim como se observa no excerto acima, a literatura sobre democratização, de uma maneira geral, sugere que a estabilidade possui uma estreita relação com diversas questões econômicas, sociais e políticas. No contexto dessa tese, ela evidencia a arena doméstica dos PALOP e os desdobramentos da sua democratização após 1990. 


\title{
14. Pressões internacionais para a democratização
}

O papel das pressões internacionais para a democratização da África foi fundamental para explicar o início dos seus processos de liberalização e transição para a democracia. Esse tema foi bastante debatido no Capítulo 1 da presente tese, sendo importante destacar algumas questões importantes para o continente africano. Conhecidas como a "segunda onda de liberalização africana", as democratizações nos anos 1990 revelaram um cenário de demandas por liberalização política que vieram primordialmente da arena externa, mas que contaram também com pressões internas importantes advindas da sociedade civil. Nesse sentido, as exigências democráticas advindas dos doadores internacionais foram usadas como uma janela de oportunidade para que transformações políticas pudessem se moldar no cenário africano no pós-Guerra Fria, conforme argumenta Kpundeh (1992):

\begin{abstract}
This new disposition toward democratization in Africa is a consequence of pressures both internal and external to African societies. To be sure, the continent's declining economic fortunes have made people more skeptical and critical of their governments, with new African thinking prompting individuals to move beyond old taboos. Demands from within African countries are pressing leaders to deliver on the promises of economic growth and prosperity they made in order to encourage the acceptance of structural adjustment policies supported by international financial institutions. The new insistence by external aid donors and creditors on good governance also has provided a window of opportunity for African democrats to push for transparency and accountability in their countries (KPUNDEH, 1992, p. 03).
\end{abstract}

De acordo com o autor, depois de 1990 os doadores internacionais passaram a preferir os Estados que fossem democráticos e que respeitassem os direitos humanos. Essa postura fez com que muitas autoridades políticas destacassem nos seus posicionamentos a importância da democracia. Nesse contexto, o ex-Embaixador norteamericano Thomas R. Pickering ressaltou a diretriz do seu país em um discurso à ONU, no qual afirmou: "It is not our role to decide who governs any country, but we will use our influence to encourage governments to get their people to make that decision for themselves" (KPUNDEH, 1992, p. 04).

Muitas das lideranças africanas compreenderam a importância que a mudança de regime político teria para o continente e para a realidade de cada país no contexto da Nova Ordem Mundial que se desdobrava com o fim da Guerra Fria. Em 1991, a 
Organização da Unidade Africana (OUA) mudou a sua ênfase da descolonização para boa governança e reconstrução econômica dos seus países-membros. Ao pronunciar o seu discurso como chairman da OUA em 1991, Ibrahim Babagagida, que era no momento presidente da Nigéria, disse às outras lideranças africanas que eles deveriam reconhecer que uma era de mudanças havia chegado à África, e que a democratização seria não somente uma escolha atrativa, mas também racional, a saber:

\footnotetext{
He told fellow leaders that they "must recognize that the time has now come to re-examine the concept and practice of power and leadership on our continent [...] Democracy is not only an attractive option but a rational one. Today, the clamour for democratization and party pluralism is on the ascendancy in Africa" (KPUNDEH, 1992, p. 04).
}

Os presidentes Aristides Pereira, de Cabo Verde, e Manuel Pinto, de São Tomé e Príncipe, estavam nesse grupo de vanguarda de lideranças africanas dispostas a realizar a mudança para a democracia. Contudo, conforme mencionado anteriormente, os presidentes dos PALOP continentais revelavam uma postura mais inflexível e reticente em relação a essas transformações políticas (VEIGA, 2014). Nesse cenário, observa-se o importante desdobramento dessa variável em relação ao perfil das elites políticas, fator que será estudado de maneira mais detalhada no próximo capítulo. Em síntese, de acordo com a análise realizada tanto no Capítulo 1 quanto nesse tópico, tem-se que as pressões internacionais para a democratização foram fundamentais para que a liberalização e transição democrática dos PALOP se iniciassem no pós-Guerra Fria.

\section{Liberalização política}

Conforme exposto no Capítulo 1 da presente tese, a liberalização política constitui a primeira fase do processo de democratização, sendo fundamental para explicar o sucesso ou insucesso da transição democrática dos PALOP. Por já ter sido abordada na referida revisão de literatura, a relação dessa variável com a democracia liberal não será analisada novamente neste tópico. 


\section{Criação de instituições democráticas fortes}

O papel das instituições democráticas foi apontado no Capítulo 1 como um dos principais aspectos que influenciam a democratização. Para muitos autores, a criação de instituições democráticas fortes constitui um aspecto fundamental para o sucesso da democratização. Schneider e Schmitter (2004) defendem essa premissa ao afirmarem que tal fenômeno é basilar para mensurar a transição democrática dos países por eles analisados. De acordo com Von Laer (2015), as instituições são construídas em bases complexas, e resultam de um processo evolucionário idiossincrático. Por já ter sido analisada anteriormente no capítulo anterior, essa variável não será escrutinizada neste tópico.

\section{Alternância efetiva de poder partidário}

Da mesma forma que as variáveis expostas acima, representadas pela liberalização política e criação de instituições democráticas fortes, a alternância efetiva de poder partidário constitui-se em um aspecto importante para a democratização que já foi analisado no Capítulo 1 da presente tese. Conforme elucidado por Przeworski (1992), a alternância de poder e o controle dos civis sobre os militares remetem ao processo final da transição democrática, indicando o seu fim.

\section{Democracia liberal}

A democracia liberal consiste na variável dependente desse estudo, abarcando tanto os direitos políticos quanto as liberdades civis. Os seus principais conceitos foram abordados no Capítulo 1, sendo importante destacar novamente que a sua mensuração ocorrerá por meio de indicadores como a Freedom House, o Polity IV e o V-DEM.

Após a análise das variáveis presentes na cadeia causal, destaca-se que sua relação não é linear, mas conectada de maneira interdependente para melhor explicar dos diferentes fenômenos históricos, sociais, políticos e econômicos presentes nos PALOP desde o domínio colonial. Também é importante mencionar que a conexão apresentada 
entre as variáveis da cadeia causal e a democracia não é determinística, assumindo formas próprias dependendo do contexto de cada país analisado. O entendimento da complexidade da cadeia causal elaborada é fundamental para a compreensão da estrutura do próximo capítulo, que será focalizada na aplicação do método comparado às realidades dos PALOP. 


\title{
PARTE II - ANÁLISE DOS PROCESSOS DE DEMOCRATIZAÇÃO DOS PALOP NO PÓS-GUERRA FRIA
}

\author{
Freedom \\ Is a strong seed \\ Planted \\ In a great need. \\ I live here, too. \\ I want freedom \\ Just as you. \\ Langston Hughes. Poema Democracy.
}

A segunda parte desta tese será focalizada em três estudos de caso. Conforme supracitado anteriormente, no Capítulo 3, o primeiro estudo de caso será baseado no período colonial português no âmbito das suas ex-colônias africanas. Já no Capítulo 4, o segundo estudo de caso abordará o imediato pós-independência, abrangendo os aproximadamente 15 anos do regime de partido único em Cabo Verde, São Tomé e Príncipe, Moçambique, Guiné-Bissau e Angola. Por fim, o Capítulo 5 será destinado ao escrutínio do terceiro estudo de caso, analisando os processos de democratização dos PALOP após a década de 1990. 


\section{CAPÍTULO 3 - ESTUDO DE CASO 1: DOMINAÇÃO COLONIAL PORTUGUESA NA ÁFRICA DURANTE O SÉCULO XX}

As armas e os Barões assinalados

Que da Ocidental praia Lusitana Por mares nunca de antes navegados Passaram ainda além da Taprobana,

Em perigos e guerras esforçados Mais do que prometia a força humana,

E entre gente remota edificaram Novo Reino, que tanto sublimaram;

E também as memórias gloriosas Daqueles Reis que foram dilatando A Fé, o Império, e as terras viciosas De África e de Ásia andaram devastando,

E aqueles que por obras valerosas Se vão da lei da Morte libertando, Cantando espalharei por toda parte, Se a tanto me ajudar o engenho e arte.

Luís Vaz de Camões. Os Lusíadas.

O presente capítulo tem como objetivo realizar um estudo de caso sobre o domínio colonial português nos PALOP, analisando comparativamente as variáveis referentes a esse período histórico de acordo com a cadeia causal exposta no Capítulo 2. Dessa forma, será possível compreender as dinâmicas sociais, políticas e econômicas da África lusófona até o ano de 1975. Na estrutura deste estudo, dez variáveis independentes antecedentes serão abordadas, sendo o primeiro tópico pautado na localização geográfica, e o último, nas independências das ex-colônias africanas de Portugal.

\section{Período histórico: dominação colonial portuguesa}

\section{VIA 1: Localização geográfica}

O primeiro tópico de análise do presente Capítulo refere-se à localização geográfica. Essa variável foi escolhida porque é comum a todos os PALOP, tendo em vista que eles estão situados no continente africano. A África, conforme exposto no capítulo anterior, caracteriza-se como um continente que apresenta uma forte presença autocrática, fator que se refletiu na realidade dos PALOP tanto no período colonial quanto 
no contexto dos regimes de partido único no pós-independência. Nesse ínterim, a análise dessa variável é a seguinte:

\section{Tabela 14 - Análise da localização geográfica dos PALOP}

\begin{tabular}{|l|l|l|l|l|l|}
\hline $\begin{array}{l}\text { Variável/ } \\
\text { País }\end{array}$ & Cabo Verde & $\begin{array}{l}\text { São Tomé e } \\
\text { Príncipe }\end{array}$ & Moçambique & $\begin{array}{l}\text { Guiné- } \\
\text { Bissau }\end{array}$ & Angola \\
\hline $\begin{array}{l}\text { Localização } \\
\text { geográfica }\end{array}$ & $\mathrm{S}$ & $\mathrm{S}$ & $\mathrm{S}$ & $\mathrm{S}$ & $\mathrm{S}$ \\
\hline
\end{tabular}

Fonte: Tabela elaborada pela autora.

\section{VIA 2: Domínio português}

A presença portuguesa na África se iniciou no século $X V^{31}$ e foi encerrada somente na década de 1970. Nesse universo, Portugal marcou a história mundial ao se consagrar tanto como o primeiro país a possuir colônias quanto como o último a reconhecer as suas independências. Esse comportamento idiossincrático no continente é destacado por Pinto (2001) no seguinte excerto:

No seu conjunto, a presença colonial europeia na África Subsaariana, entendida aqui como controle político e administrativo direto dos territórios, foi rápida e tardia. Portugal experimentou os parâmetros máximos da escala: a mais antiga presença; uma curta colonização efetiva; a mais tardia das descolonizações europeias (PINTO, 2001, p. 09).

Para entender a dinâmica do comportamento português na África, é importante destacar que, ao contrário do que fora observado na América do Sul, a colonização iniciou-se em 1884, sendo amplamente efetivada somente depois da Primeira Guerra Mundial, por meio da instauração de uma administração pública direta e de companhias majestáticas (MOSCA, 2001). De acordo com Penna Filho (2015), a imigração portuguesa para a África ocorreu de maneira gradativa, sendo focalizada primordialmente em Angola ${ }^{32}$.

\footnotetext{
${ }^{31} \mathrm{O}$ início da expansão marítima portuguesa ocorreu com a conquista da cidade de Ceuta, no norte da África, em 1415. Em 1446, os portugueses chegaram à Guiné-Bissau; em 1460, à Cabo Verde; em 1471, à São Tomé e Príncipe; em 1482, à Angola e, finalmente, em 1498, à Moçambique. Dessa forma, o Império Português já existia no continente africano antes da chegada de Pedro Álvares Cabral ao Brasil (TVBRASIL, 2015).

${ }^{32}$ Em 1975, como resultado da grande imigração portuguesa para Angola, o país abrigava aproximadamente um milhão de colonos. Nesse mesmo período, o número de portugueses em Moçambique era inferior a 250.000 (TVBRASIL, 2015).
} 
A atuação internacional de Portugal durante o século XX encontra-se intrinsecamente conectada aos desdobramentos do seu governo autocrático, que perdurou de 1926 a $1974^{33}$. Durante o mandato do Presidente do Ministério (primeiro-ministro) Domingos da Costa Oliveira (1930-1932), Salazar detinha o cargo de Ministro Interino das Colônias e, seguindo a diretriz de preservação dos territórios portugueses no ultramar, publicou o "Ato Colonial” de 1930, que foi incorporado à Constituição em 1933 (ver Anexo C). O documento redefiniu a relação entre a metrópole e as suas colônias, trazendo grande repressão e consequente insatisfação dos povos africanos (TESSADORI, 2012). Entre os seus artigos, destaca-se o segundo, no qual Portugal afirma ter uma função colonizadora e civilizatória nos seus domínios, a saber:

É da essência orgânica da Nação Portuguesa desempenhar a função histórica de possuir e colonizar domínios ultramarinos e de civilizar as populações indígenas que neles se compreendam, exercendo também influência moral que lhe é adstrita pelo Padroado do Oriente (ACTO COLONIAL. Decreto-Lei No. 22.465 de 11 de Abril de 1933, artigo $2^{\circ}$ ).

Dessa forma, a justificativa dos mais de 500 anos da presença portuguesa na África baseava-se em uma "vocação nacional sagrada" do país no continente (MACQUEEN, 2014). Para Tessadori (2012), a explicação do domínio autocrático de Portugal se apresenta da seguinte maneira:

\begin{abstract}
Salazar apresentou ao país os seus" Princípios Fundamentais da Nova Ordem das Causas", ou seja as bases ideológicas e políticas do partido único, em que o património colonial português era justificado como um direito histórico devido à vocação portuguesa de ser uma grande Nação descobridora, com direito natural num património marítimo, territorial, político e espiritual, este último comemorado com o "Acordo missionário" com a Santa Sé, através do qual o regime colocou na sua política colonial, um processo de assimilação e de dominação cultural que aproveitava do suporto da ação missionária (TESSADORI, 2012, p. 112).
\end{abstract}

Além disso, a partir de um determinado momento, o Estado Novo pautou-se no mito do lusotropicalismo, no qual defendia que o colonialismo português era diferente dos outros, tendo em vista que eles efetivamente se misturavam aos povos tropicais

\footnotetext{
${ }^{33}$ O período ditatorial de Portugal no século XX perdurou de 1926 a 1974, dividindo-se em duas partes: a primeira foi constituída pela Ditadura Militar, que ocorreu de 1926 a 1933; e a segunda, se relacionava ao Estado Novo, que se desdobrou de 1933 a 1974. O Estado Novo chegou ao fim por meio da Revolução de 25 de Abril de 1974 (SOUSA, 2009).
} 
colonizados, formando uma nação multirracial (TVBRASIL, 2015). Contudo, Marcello Caetano, que era presidente do Conselho de Ministros (equivalente a primeiro-ministro) de Portugal entre 1968 e 1974, deixou clara a maneira preconceituosa na qual a constituição plural de raças seria pautada no âmbito colonial português, afirmando em seus escritos que: "The blacks in Africa must be directed and organized by Europeans, but are indispensable as auxiliaries... [and] must be regarded as productive elements organized or to be organized in an economy directed by the whites" (FERREIRA, 1974, p. 11).

À parte da tentativa portuguesa de tentar justificar interna e externamente um colonialismo brutal que se fortalecia na primeira metade do século XX, o novo sistema político que decorreu do "Ato Colonial” impôs a diminuição da autonomia das colônias por meio de inúmeras medidas protecionistas que favoreciam a metrópole. Nesse ínterim, estabeleceram-se relações significativamente discriminatórias, fazendo com que, em algumas localidades, muitas das condições de trabalho chegassem à extrema exploração dos africanos. Em 1951, o Ato foi revogado e a política do Estado Novo mudou a designação do termo "colônias" para "províncias ultramarinas", por meio da Lei Orgânica do Ultramar Português de 1953. Contudo, Tessadori (2012) afirma que, até 1974, Moçambique e Angola ainda eram controlados "por grandes empresas monopolísticas de Portugal, que se baseiam na exploração física dos nativos em condições de trabalho escravistas" (TESSADORI, 2012, p. 114). Isso significa que, mesmo após a revogação do Ato, as suas características opressoras continuaram sendo aplicadas às sociedades dos PALOP.

Depois da Segunda Guerra Mundial, diversos países europeus, tais como Inglaterra e Holanda, aceitaram negociar as independências das suas colônias na África e na Ásia após a forte atuação de inúmeros grupos de nativos que contestavam o domínio estrangeiro. Contudo, Portugal não estava aberto para a construção de um diálogo com os movimentos de libertação originários nos territórios por eles colonizados, recusando-se a estabelecer qualquer tipo de acordo que resultasse na soberania das suas províncias ultramarinas ao redor do mundo. Salazar justificava esse comportamento pautando-se nas premissas de nação pluricontinental, una e indivisível, que se estendia do "Minho ao Timor”. Nesse contexto, a defesa do território português no ultramar era considerada uma questão basilar para o Estado autocrático do governo Salazar-Caetano (CITI, 2016). 
Em 1955, Portugal ingressou como membro da Organização das Nações Unidas $(\mathrm{ONU})$ e recebeu a recomendação de conceder a independência às suas colônias. Contudo, essa determinação não foi cumprida. O posicionamento português foi rechaçado pela Assembleia-Geral da instituição, marcando um momento de mudanças significativas na arena doméstica das suas colônias, que já nos anos seguintes começaram a lutar pela libertação (CITI, 2016). Com o passar dos anos, as pressões internacionais para a independência das colônias lusófonas na ONU intensificaram-se, notadamente porque um grande número de Estados africanos recém-independentes tinha a intenção de apoiar resoluções a favor dos grupos independentistas (FORTUNA, 1985). Nesse cenário, Fortuna (1985) afirma que "Portugal chegou a 1960 só, supostamente orgulhoso e, decididamente, fora do tempo" (FORTUNA, 1985, p. 494).

Para Afonso (2009), o ano de 1961 marcou o início da queda do regime português. Andringa (2016) afirma que esse foi o "ano de todos os perigos", no qual o colonialismo de Portugal foi condenado "por Washington, pelo Vaticano e pelos ventos da história" (ANDRINGA, 2016, p. 01). Entre os inúmeros acontecimentos domésticos e externos importantes que tiveram desdobramentos fundamentais para o país, destacamse, em ordem cronológica, os seguintes fenômenos:

Logo em janeiro, a repressão dos trabalhadores da Baixa do Cassange, em Angola, acontecimento que ficará para sempre ligado ao início da revolta das populações; a posse do presidente John Kennedy, nos Estados Unidos, que mudaria o sentido da sua política externa no que respeita ao movimento descolonizador, criando imensas dificuldades diplomáticas ao regime português; e o assalto ao paquete "Santa Maria", por Henrique Galvão, que ficou sempre como um símbolo da oposição ao regime de Salazar. Depois, em fevereiro, a revolta de Luanda, iniciada no dia quatro, que virá a ser considerada como o despontar da luta armada neste território. Em março tem início a revolta do Norte de Angola, com imensas vítimas entre a população branca e os trabalhadores oriundos de outras regiões de Angola. Segue-se, em abril, a tentativa de golpe de Estado conduzida pelo ministro da Defesa, general Botelho Moniz, rapidamente anulada por Salazar, mas que ficou sempre na memória militar (ou pelo menos de alguns militares), como sinal de oposição à política colonial do regime. Já em agosto, é de assinalar a ocupação de $\mathrm{S}$. João Baptista de Ajudá pelo Daomé (atual Benim). Finalmente, em dezembro, ocorreu a invasão dos territórios da Índia Portuguesa por forças da União Indiana (AFONSO, 2009, p. 01). 
Os movimentos independentistas das ex-colônias lusófonas iniciaram-se por meio da supracitada invasão da Índia Portuguesa. Por meio de uma guerra de pequenas dimensões na Costa do Malabar (Goa, Damão e Diu), Portugal perdeu esses territórios já em 1961 (CITI, 2016). As guerras de libertação na África ocorreram em Angola, Moçambique e Guiné-Bissau, perdurando de 1961 a 1974. Ao retratar esses conflitos, Afonso (2009) afirma que seus desdobramentos ocorreram da seguinte maneira:

Estiveram em confronto as Forças Armadas portuguesas e as forças organizadas pelos movimentos de libertação de cada uma daquelas colônias. Os movimentos de libertação que especialmente se opuseram a Portugal em cada um dos territórios foram os seguintes: em Angola, a UPA, União dos Povos de Angola, depois transformada em FNLA, Frente Nacional de Libertação de Angola; o MPLA, Movimento Popular de Libertação de Angola; e a UNITA, União Nacional para a Independência Total de Angola. Na Guiné, o PAIGC, Partido Africano para a Independência da Guiné e Cabo Verde. Em Moçambique, a FRELIMO, Frente para a Libertação de Moçambique (AFONSO, 2009, p. 01).

Apesar dos PALOP insulares (Cabo Verde e São Tomé e Príncipe) não terem tido conflitos armados em seus territórios, eles participaram, cada um à sua maneira, dos movimentos de resistência ao domínio colonial português. Nesse ínterim, destaca-se que muitos cabo-verdianos lutaram pela independência na Guiné-Bissau, participando ativamente das lideranças do PAIGC.

A repressão colonial tornou-se ainda maior depois do início das guerras de liberação, instaurando um período no qual inúmeras medidas discriminatórias entraram em vigor. Nesse contexto, intensificou-se o assédio físico e moral aos africanos, no qual uma forte ação policial ocorreu com interrogatórios e torturas nas prisões e campos de concentração (TESSADORI, 2012). Além disso, inúmeros crimes de guerra foram cometidos por Portugal, a saber:

Nomeadamente com o início das guerras coloniais, em 1962, se evidenciaram os trechos mais brutais do regime português, bombardeamentos ao napalm e massacres de civis já se tornaram recorrentes para a utilização de milhares de tropas enviadas para a África, com conseguintes e repetidas condenações do regime de Salazar nas assembleias Geral da Organização das Nações Unidas (ONU) (TESSADORI, 2012, p. 115). 
Fortuna (1985) afirma que, com a guerra colonial que se estabeleceu em três frentes, o domínio português perdeu legitimidade não somente no âmbito das colônias, mas também nos seus contextos doméstico e internacional. Nesse sentido, também destaca que queda do regime autocrático português foi motivada por esses conflitos, a saber:

\begin{abstract}
Ao lado desta resistência armada prolongada dos povos africanos, o colonialismo português foi também, e ao contrário dos outros colonialismos, simultaneamente deslegitimado pelos seus próprios agentes diretos dessa guerra, por variadas forças sociais nacionais, por setores e organizações progressistas estrangeiros e pela própria comunidade internacional. Enfim, o colonialismo português é diferente dos outros pelo fato de uma vez chegado ao seu termo, ter arrastado consigo o próprio regime político que nele se apoiava (FORTUNA, 1985, p. 472).
\end{abstract}

Para Fortuna (1985), o domínio colonial português teve características específicas que o diferenciava de outros tipos de colonização, tais como a francesa ou a britânica. A principal diferença situa-se no fato de que Portugal exercia um duplo papel no mundo capitalista durante a Guerra Fria: ao mesmo tempo em que era classificado como um país semiperiférico no contexto global, ou seja, "um estado sem os recursos políticos, econômicos, financeiros e militares dos seus pares" (FORTUNA, 1985, p. 470), desempenhava uma função central no relacionamento com suas colônias.

Conforme exposto no Capítulo 2, o tipo de colonização pode influenciar na maneira que a democracia se instaura em determinado Estado no pós-independência. Reforçando a importância dessa variável, Chabal (1996) afirma que o impacto da colonização portuguesa nos PALOP foi muito significativo. Dessa forma, mesmo tendo apresentado características singulares em cada região, é possível identificar um conjunto de similaridades relacionadas ao domínio colonial de Portugal na África. Nesse escopo, os seguintes fenômenos foram compartilhados por todos esses países, a saber:

a) Tiveram um governo colonial repressor, notadamente após o Ato Colonial de 1930

b) Tornaram-se territórios ultramarinos após 1951;

c) Não tiveram as suas independências negociadas após a Guerra Mundial; 
d) Engajaram-se em lutas pela independência, apesar do conflito armado não ter se concretizado nos PALOP insulares ${ }^{34}$;

e) Enfrentaram uma repressão da metrópole ainda maior depois do início dos conflitos armados e

f) Tiveram a formação dos seus Estados nacionais realizada por meio dos partidos políticos que lutaram pela independência.

Nesse ínterim, a variável "domínio colonial português" foi comum a todos os PALOP, conforme se observa na tabela abaixo:

Tabela 15 - Análise do domínio colonial português nos PALOP

\begin{tabular}{|l|l|l|l|l|l|}
\hline $\begin{array}{l}\text { Variável/ } \\
\text { País }\end{array}$ & Cabo Verde & $\begin{array}{l}\text { São Tomé e } \\
\text { Príncipe }\end{array}$ & Moçambique & $\begin{array}{l}\text { Guiné- } \\
\text { Bissau }\end{array}$ & Angola \\
\hline $\begin{array}{l}\text { Domínio } \\
\text { português }\end{array}$ & $\mathrm{S}$ & $\mathrm{S}$ & $\mathrm{S}$ & $\mathrm{S}$ & $\mathrm{S}$ \\
\hline
\end{tabular}

Fonte: Tabela elaborada pela autora.

\section{VIA 3: Crescimento econômico durante o período colonial português}

Conforme mencionado no tópico anterior, durante o século XX Portugal ocupou um lugar semiperiférico na economia do planeta, produzindo primordialmente commodities e importando produtos manufaturados. A competitividade dos produtos portugueses no mercado internacional era bastante reduzida, sendo a sua produção de manufaturas direcionada primordialmente para o mercado interno (FORTUNA, 1985).

Durante o domínio colonial, a exploração econômica dos territórios africanos se configurou como uma importante fonte de receitas para o governo português. Nesse cenário observava-se o duplo papel do país na economia-mundo: ao mesmo tempo em que ocupava um espaço marginal no contexto global, exercia uma atuação econômica central e forte na sua relação com a África. Como uma das primeiras ações colonizadoras, a metrópole introduziu moedas e notas nas colônias, impactando os seus mercados de

\footnotetext{
${ }^{34}$ Nesse contexto, Saraiva (2015) afirma que "os PALOP são Estados que derivam sua modernidade de um processo tardio de descolonização atabalhoada. Algumas dessas cinco nações permaneceram, até recentemente, esgarçadas por guerras fraticidas ou desinteligências domésticas que comprometem a transformação positiva" (SARAIVA, 2015, p. 110).
} 
commodities de sal e ferro (TESSADORI, 2012). Dessa forma, Mosca (2001) afirma que foi instaurada a seguinte dinâmica econômica nas ex-colônias lusófonas africanas:

A reestruturação da economia em Portugal, com a modernização da agricultura e com o processo de industrialização e as consequentes alterações das relações entre os fatores de trabalho e capital, aumentaram, por um lado, a procura de produtos primários até então fornecidos principalmente pelas colônias e, por outro, a oferta de bens industrializados que deveriam ser consumidos pelo crescente mercado africano (MOSCA, 2001, p. 59).

Nesse contexto, as colônias forneciam matérias-primas para a metrópole, ao mesmo tempo, consumiam os seus produtos industrializados. $\mathrm{O}$ "Ato Colonial" tornou esse relacionamento ainda mais profundo, fazendo que o balanço de pagamento português pudesse ser equilibrado por meio das relações comerciais com a África. Apesar da importância que a exploração das colônias exerceu para a estabilidade econômica de Portugal, muitos autores acreditam que o colonialismo português não foi movido primordialmente por questões financeiras (FORTUNA, 1985). Na visão desses acadêmicos, a presença portuguesa na África era sustentada também pelos princípios de "prestígio nacional” e pela sua "missão histórica e civilizacional”, a saber:

Não existem no modelo colonial-imperialista português motivações econômicas determinantes. Existe, quando muito, a perspectiva de benefícios econômicos a retirar futuramente do empreendimento colonial. Daí a necessidade prévia de garantir politicamente tal possibilidade. Não admira, portanto, que a política desse período colonial-imperialista de Portugal assentasse nos contatos políticos internacionais de modo a garantir a "regra do homem branco" em África (FORTUNA, 1985, p. 490).

Devido à maneira que foi sistematizada a colonização portuguesa, o crescimento econômico dos PALOP até 1974 foi relativamente reduzido e instável, sendo a sua função pautada majoritariamente na exportação de produtos primários. Por haver um limitado escopo de informações econômicas sobre esse período, os principais indicadores utilizados para medir a variável relativa ao crescimento econômico dos PALOP até a independência pautam-se nas taxas de crescimento do PIB e no PIB per capita desses países. Conforme se observa na tabela abaixo, destaca-se que em 1975, após anos de guerra de independência, a taxa de crescimento do PIB de Moçambique foi de -16,65\%, enquanto os percentuais de Angola foram de $-37,28 \%$. 
Tabela 16 - Taxa percentual de crescimento do PIB dos PALOP entre 1951 e 1975 (V-DEM, 2016)

\begin{tabular}{|l|l|l|l|l|l|l|}
\hline & $\mathbf{1 9 5 1}$ & $\mathbf{1 9 5 5}$ & $\mathbf{1 9 6 0}$ & $\mathbf{1 9 6 5}$ & $\mathbf{1 9 7 0}$ & $\mathbf{1 9 7 5}$ \\
\hline Cabo Verde & 1,26 & 0,50 & 4,38 & 1,87 & 1,35 & 2,53 \\
\hline $\begin{array}{l}\text { São Tomé e } \\
\text { Príncipe }\end{array}$ & $-0,31$ & $-10,14$ & 10,66 & 4,74 & 3,65 & 4,85 \\
\hline $\begin{array}{l}\text { Moçambique } \\
\text { Guiné-Bissau }\end{array}$ & 1,94 & 4,33 & 0,35 & 0,11 & 2,94 & $-16,65$ \\
\hline Angola & 2,32 & $-4,62$ & 4,74 & 6,81 & 4,64 & 1,39 \\
\hline
\end{tabular}

Fonte: Tabela elaborada pela autora com dados do V-DEM (2016).

Já no âmbito do PIB per capita, tem-se valores muito baixos para todos os PALOP, especialmente para Cabo Verde e Guiné-Bissau. É interessante notar que após as guerras de independência houve uma significativa queda desses valores em Angola e Moçambique. Essa redução fez com que, em 1975, o PIB per capita de São Tomé e Príncipe fosse o maior dos PALOP, mesmo o país vivenciando nesse momento uma crise marcada por restrições à sua economia cacaueira (MATA; IZERROUGENE, 2013). O reduzido crescimento econômico de Cabo Verde possui uma explicação histórica, tendo em vista que depois do fim da escravidão, o interesse de Portugal nas ilhas reduziu drasticamente, levando o país a uma situação de abandono. Como consequência deste período, o território cabo-verdiano perpassou inúmeras mazelas, primordialmente ligadas às fomes ocasionadas pelas secas prolongadas aliadas ao descaso das elites políticas coloniais em solucionar ou prevenir os seus impactos negativos (PEREIRA, 2013). No século XX, três grandes crises de fome impactaram o país, a saber: a) a primeira ocorreu entre 1921 e 1922 e resultou em 23 mil mortes, sendo classificada como o "último estágio de miséria nua" em Cabo Verde; b) a segunda aconteceu entre 1941 e 1943, com um total de 24 mil mortes e, finalmente, c) a terceira perpassou os anos de 1947 e 1948, resultando em uma quantidade de mortes e de deslocamentos tão intensos que não conseguiram ser contabilizados pelas autoridades. O poeta Manuel Ferreira (1972) retrata essas crises no seguinte excerto:

Fome oculta, fome crônica, fome epidêmica, fome total. A boqueira, beriberi, a caquexia, o inchaço, a pelagra: larvando. A pelagra na sua destruição dos três 
d: dermatose, diarreia, demência. E nesta dura caminhada, nesta longa odisseia, dezenas de milhar caídos de morte morrida, morte matada (FERREIRA, 1972, p. 08).

Já Fernandes (2014) descreve esse momento de dominação colonial como "a fome de saber e de comida; a falta de liberdade e a negação de dignidade; o aumento da pobreza; a proliferação da injustiça; a legalização da morte" (FERNANDES, 2014, p. 18). Essas crises fomentaram uma forte emigração, notadamente para a Europa os Estados Unidos, gerando o fenômeno que ficou caracterizado como "Diáspora Cabo-verdiana". Em síntese, os dados relacionados ao PIB per capita dos PALOP de 1950 a 1975 podem ser verificados na tabela a seguir:

Tabela 17 -PIB per capita dos PALOP entre 1950 e 1975 (V-DEM, 2016)

\begin{tabular}{|l|l|l|l|l|l|l|}
\hline & $\mathbf{1 9 5 0}$ & $\mathbf{1 9 5 5}$ & $\mathbf{1 9 6 0}$ & $\mathbf{1 9 6 5}$ & $\mathbf{1 9 7 0}$ & $\mathbf{1 9 7 5}$ \\
\hline Cabo Verde & 449,65 & 462,75 & 507,52 & 574,72 & 618,96 & 524,74 \\
\hline $\begin{array}{l}\text { São Tomé e } \\
\text { Príncipe }\end{array}$ & 820,36 & 763,78 & 867,47 & $1.164,64$ & $1.439,61$ & $1.421,45$ \\
\hline Moçambique & $1.133,42$ & $1.258,80$ & $1.327,33$ & $1.350,92$ & $1.742,85$ & $1.421,45$ \\
\hline Guiné-Bissau & 289,15 & 388,98 & 500,77 & 685,25 & 871,56 & 925,07 \\
\hline Angola & $1.051,82$ & $1.178,48$ & $1.252,98$ & $1.595,77$ & $1.767,69$ & $1.072,81$ \\
\hline
\end{tabular}

Fonte: Tabela elaborada pela autora com dados do V-DEM (2016).

Enquanto os PALOP continentais apresentavam um crescimento econômico reduzido, que se explica em grande parte pela presença das guerras de independência nos seus territórios, os PALOP insulares refletiram nesses dados as suas vulnerabilidades advindas do fato de serem microestados insulares. Espírito Santo (2013) afirma que as economias dos pequenos Estados insulares possuem características únicas que as distinguem dos países continentais de maiores dimensões. O isolamento geográfico combinado com um território limitado e uma população reduzida fizeram com que esses arquipélagos vivenciassem inúmeros problemas e fragilidades estruturais. Durante o período colonial em Cabo Verde e São Tomé e Príncipe, essas questões econômicas foram evidenciadas sob os seguintes aspectos:

a) Pouca competitividade na implantação de uma economia de escala; 
b) Poucas possibilidades de investimento interno (ou de Portugal), que devido ao isolamento e pouca população refletiam em custos de produção mais elevados e menores retornos financeiros;

c) Exportação de produtos relativamente pouco demandados pelo mercado internacional, tais como cacau, café e açúcar (reduzindo o interesse de investimento produtivo da metrópole nesses territórios, notadamente em Cabo Verde);

d) Inexistência de recursos naturais e forte dependência de recursos externos advindos de Portugal;

e) Dificuldade para construir e manter obras de infraestrutura, que se explica pelos obstáculos presentes na obtenção de matéria-prima e na contratação de mão-deobra qualificada para realizar a construção e manutenção dessas infraestruturas.

Dessa forma, observa-se que durante o período colonial, todos os PALOP apresentaram um desenvolvimento econômico relativamente baixo, sendo possível construir a seguinte tabela:

Tabela 18 - Análise do crescimento econômico dos PALOP durante o regime colonial português

\begin{tabular}{|l|l|l|l|l|l|}
\hline Variável/ País & $\begin{array}{l}\text { Cabo } \\
\text { Verde }\end{array}$ & $\begin{array}{l}\text { São Tomé e } \\
\text { Príncipe }\end{array}$ & Moçambique & $\begin{array}{l}\text { Guiné- } \\
\text { Bissau }\end{array}$ & Angola \\
\hline $\begin{array}{l}\text { Crescimento } \\
\text { econômico }(\mathrm{t} 1)\end{array}$ & $\mathrm{N}$ & $\mathrm{N}$ & $\mathrm{N}$ & $\mathrm{N}$ & $\mathrm{N}$ \\
\hline
\end{tabular}

Fonte: Tabela elaborada pela autora.

\section{VIA 4: Desenvolvimento social durante o período colonial}

No período colonial, o sistema educacional das colônias era pautado na cultura e nos valores portugueses. Nesse cenário, Tessadori (2012) destaca que:

A política autoritária do regime se enfoca na preocupação de "educação" dos africanos por meio de uma assimilação à cultura portuguesa, um sistema educacional baseado na exaltação dos valores nacionais, entre quais o passado histórico caracterizado pelo mito do grande Império Português, a tradição, a pátria e a religião numa perspectiva cristã portadora de uma missão evangelizadora. Este esforço de assimilação, que começa com o Estatuto do Indigenato em 1926, visa mostrar o colonialismo português como algo de natural, uma forma de presunção colonizadora, que considera a sua ação 
coercitiva uma dimensão pedagógica até desejada pelos povos colonizados (TESSADORI, 2012, p. 112).

Fraga (2014) afirma que a educação nas colônias era muito elitista, direcionando-se majoritariamente para os brancos e para um pequeno número de negros, a saber: "nas maiores cidades existiam liceus e escolas comerciais e industriais que serviam essencialmente a minoria branca e uma quase inexistente pequena burguesia negra ou mista oriunda de atividades ligadas ao funcionalismo público" (FRAGA, 2014, p. 04).

Assim como ocorrera com o crescimento econômico, durante o governo colonial o desenvolvimento social de todos os PALOP também era reduzido. Contudo, destaca-se que no escopo dessa variável, os PALOP insulares apresentam resultados mais positivos quando comparados aos continentais. Nesse contexto, os indicadores utilizados para mensurar o desenvolvimento social dividem-se em três eixos: a) expectativa de vida; b) taxa de mortalidade infantil e c) taxa de alfabetização/ taxa de matrícula no ensino primário.

Conforme se observa na tabela a seguir, é possível identificar que de 1951 a 1975, houve um aumento da expectativa de vida de todos os PALOP. Contudo, Cabo Verde e São Tomé e Príncipe apresentaram dados muito melhores do que os PALOP continentais no decorrer de toda a sua trajetória no século $\mathrm{XX}$, destacando-se que, em Angola e Moçambique, a expectativa de vida era de aproximadamente 30 anos em 1950, aumentando para somente 40 anos em 1975. Uma das possíveis explicações pode ser baseada no fato de que, além de serem microestados insulares, a inexistência de conflitos armados fez com que nos dois arquipélagos esses números fossem mais reduzidos ${ }^{35}$, a saber:

\footnotetext{
${ }^{35}$ Para fins de comparação, a expectativa de vida em 1950 no Brasil era de 50,04 anos, 58,53 em Portugal, 68,12 nos Estados Unidos, 59,30 no Japão, 46,68 na Coreia do Sul e 43,55 na África do Sul (V-DEM, 2016).
} 
Tabela 19 - Expectativa de vida dos PALOP entre 1950 e 1975 (V-DEM, 2016)

\begin{tabular}{|l|l|l|l|l|l|l|}
\hline & $\mathbf{1 9 5 0}$ & $\mathbf{1 9 5 5}$ & $\mathbf{1 9 6 0}$ & $\mathbf{1 9 6 5}$ & $\mathbf{1 9 7 0}$ & $\mathbf{1 9 7 5}$ \\
\hline Cabo Verde & 47,80 & 48,40 & 49,06 & 49,69 & 52,21 & 56,98 \\
\hline $\begin{array}{l}\text { São Tomé e } \\
\text { Príncipe }\end{array}$ & 45,55 & 47,57 & 50,37 & 53,12 & 55,86 & 58,98 \\
\hline Moçambique & 30,28 & 32,55 & 35,03 & 37,17 & 39,25 & 41,56 \\
\hline Guiné-Bissau & 38,78 & 40,47 & 42,17 & 43,18 & 44,05 & 44,85 \\
\hline Angola & 29,21 & 31,00 & 33,00 & 35,01 & 37,03 & 39,00 \\
\hline
\end{tabular}

*A expectativa de vida é medida em anos.

Fonte: Tabela elaborada pela autora com dados do V-DEM (2016).

Na tabela abaixo, nota-se que de 1960 a 1976, houve uma diminuição da mortalidade infantil de todos os PALOP analisados (com exceção da Guiné-Bissau, que só tem dados disponíveis a partir de 1976). Mais uma vez, Cabo Verde e São Tomé e Príncipe apresentaram índices muito melhores do que os PALOP continentais. Nesse ínterim, ressalta-se em 1960, São Tomé e Príncipe apresentava valores melhores do Brasil, Portugal, África do Sul e Coreia do Sul. Em 1975, o arquipélago ainda apresentava resultados melhores do que Brasil e África do Sul, sendo que os valores cabo-verdianos também eram superiores aos brasileiros ${ }^{36}$. Já em 1976, o PALOP que apresentava o menor índice de mortalidade infantil continuava a ser São Tomé e Príncipe, que tinha uma taxa de mortalidade infantil 65\% menor do que a de Moçambique, PALOP que apresentava os piores índices. De acordo com o DATASUS (2012), o índice de mortalidade infantil é considerado "alto" quando acontecem mais de 50 mortes a cada 1.000 nascimentos, "médio" quando esse valor se mostra entre 20 e 49 e, finalmente, é classificado como "baixo" quando resulta em menos de 20 mortes. Apesar da taxa de mortalidade dos PALOP insulares se mostrar significativamente menor do que a dos continentais, ela ainda se encontrava alta até o ano de 1976, a saber:

\footnotetext{
${ }^{36}$ Para fins de comparação, a mortalidade infantil em 1960 era de 129,70 no Brasil, 84,40 em Portugal, 84,36 na África do Sul, 30,40 no Japão, 25,90 nos Estados Unidos e 84,36 na Coreia do Sul. Já em 1975, os valores eram 88,90 para o Brasil, 36,10 para Portugal, 83,3 para a África do Sul, 10,0 para o Japão, 16,0 para os EUA e 22,60 para a Coreia do Sul.
} 
Tabela 20 - Taxa de mortalidade infantil dos PALOP entre 1960 e 1976 (V-DEM, 2016)*

\begin{tabular}{|c|c|c|c|c|}
\hline & 1960 & 1965 & 1970 & 1976 \\
\hline Cabo Verde & - & - & 120,00 & 83,30 \\
\hline $\begin{array}{l}\text { São Tomé e } \\
\text { Príncipe }\end{array}$ & 69,00 & 61,40 & 56,50 & 58,20 \\
\hline Moçambique & 183,00 & 179,60 & 176,00 & 171,50 \\
\hline Guiné-Bissau & - & - & - & 136,30 \\
\hline Angola & 208,00 & 194,00 & 180,00 & 152,16 \\
\hline
\end{tabular}

*O V-DEM só apresenta dados sobre a mortalidade infantil dos PALOP a partir de 1960. Outras bases de dados, tais como a do Banco Mundial, também não apresentam dados relacionados a essa variável para um período anterior a 1960. Guiné-Bissau só tem dados disponíveis a partir de 1976

Fonte: Tabela elaborada pela autora com dados do V-DEM (2016).

Mais uma vez, assim como observado com os dados anteriores, durante o período colonial as taxas relacionadas à educação dos PALOP insulares foram melhores do que as dos PALOP continentais. No âmbito das taxas de matrícula no ensino primário, tem-se que em 1971 somente $12 \%$ da população de São Tomé e Príncipe se encontrava matriculada no ensino básico, enquanto essa taxa era de ainda menor em Angola (7\%) e em Moçambique $(5 \%)^{37}$. Nesse contexto, é possível relacionar a realidade dos PALOP aos estudos de Anckar (2002), que foram expostos no Capítulo 2 da presente tese, no qual o autor afirma que as taxas de alfabetização dos microestados insulares são normalmente são maiores do que as dos outros países do mundo. Na tabela a seguir, nota-se que apesar das taxas de analfabetismo de Cabo Verde em 1958 se apresentarem expressivas (78,5\%), elas ainda eram quase $20 \%$ menores do que as identificadas nos PALOP continentais, a saber:

\footnotetext{
${ }^{37}$ Os cálculos foram realizados pela autora utilizando as taxas de quantidade de alunos matriculados na educação primária em 1971 de acordo com o Banco Mundial (2016). A quantidade da população de cada país foi obtida por meio do V-DEM (2016), no qual São Tomé e Príncipe apresentava, em 1971, 75.735 habitantes, enquanto Angola tinha 6.260.319 e Moçambique, 9.717.800 cidadãos. A quantidade de alunos matriculados na educação primária em São Tomé e Príncipe em 1971 era de 9.018 alunos, em Angola era de 437.370 alunos e, em Moçambique, d 496.910 alunos.
} 
Tabela 21 - Taxa de analfabetismo dos PALOP em 1958 (FERREIRA, 1974)

\begin{tabular}{lrrc}
\hline & $\begin{array}{c}\text { Total } \\
\text { population }\end{array}$ & $\begin{array}{c}\text { Illiterate } \\
\text { population }\end{array}$ & $\begin{array}{c}\text { Percentage of } \\
\text { illiterates }\end{array}$ \\
\hline Angola & $4,145,266$ & $4,019,834$ & 96.97 \\
Cape Verde & 148,331 & 116,844 & 78.50 \\
Guinea & 510,777 & 504,928 & 98.85 \\
Mozambique & $5,738,911$ & $5,615,053$ & 97.86
\end{tabular}

Sources: Anuário Estatistico do Ultramer 1958, Instituto Nacional de Estatistica, Lisbon, and calculations by the author.

Fonte: FERREIRA, 2014, p. 71.

Conforme a análise realizada no escopo da expectativa de vida, da mortalidade infantil e das taxas de matrícula no ensino primário e analfabetismo, observa-se que o desenvolvimento social se apresentou baixo em todos os PALOP durante o regime colonial. Contudo, é importante destacar que nesse universo, os PALOP insulares mostraram resultados superiores quando aos comparados aos seus pares continentais. Dessa forma, é possível construir a seguinte tabela:

Tabela 22 - Análise do desenvolvimento social (relativo) dos PALOP durante o regime colonial português

\begin{tabular}{|l|l|l|l|l|l|}
\hline Variável/ País & $\begin{array}{l}\text { Cabo } \\
\text { Verde }\end{array}$ & $\begin{array}{l}\text { São Tomé e } \\
\text { Príncipe }\end{array}$ & Moçambique & $\begin{array}{l}\text { Guiné- } \\
\text { Bissau }\end{array}$ & Angola \\
\hline $\begin{array}{l}\text { Desenvolvimento } \\
\text { social (t1) }\end{array}$ & $\mathrm{N}$ & $\mathrm{N}$ & $\mathrm{N}$ & $\mathrm{N}$ & $\mathrm{N}$ \\
\hline
\end{tabular}

Fonte: Tabela elaborada pela autora.

\section{VIA 5: Insularidade e microestado}

A insularidade se mostrou como um aspecto muito importante para explicar a trajetória democrática dos PALOP. Cabo Verde e São Tomé e Príncipe são arquipélagos que, devido ao seu pequeno tamanho populacional, também são considerados microestados. Nesse ínterim, destaca-se que, por possuir uma população de aproximadamente 160 mil habitantes, São Tomé e Príncipe apresenta-se como o segundo país menos populoso da África, estando atrás somente de Seychelles. Além disso, as terras são-tomenses são mais férteis do que as cabo-verdianas, o que fez com que a sua 
agricultura prosperasse principalmente com a produção de café e cacau, utilizando muitas vezes mão-de-obra escrava vinda de Angola (EPORTUGUESE, 2008).

Destaca-se também que ambos os PALOP insulares são compostos por ilhas vulcânicas, e encontravam-se inabitados no momento da chegada dos portugueses (há aproximadamente 500 anos), servindo como entrepostos comerciais no primeiro momento da colonização. Nesses dois países, a população foi formada por etnias crioulas, trazendo um contexto de relativa homogeneidade étnica (CHABAL, 1996), fator que pode ajudar a explicar a inexistência de conflitos étnicos, religiosos os culturais nos seus territórios.

O fato de serem microestados insulares se mostrou muito importante para a constituição histórica de Cabo Verde e de São Tomé e Príncipe. Além de propiciar uma arena social de maior coesão, trouxe desde a sua gênese inúmeras vantagens em relação aos PALOP continentais, tais como melhores indicadores econômicos, sociais e políticos ${ }^{38}$. Além disso, outro fator importante deve ser destacado no escopo dessa variável: as guerras de independência não puderam ser realizadas nos PALOP insulares porque não havia como chegar suprimentos e se estruturar um conflito no formato de guerrilhas nesses Estados. Ao analisar o percurso histórico recente dos PALOP insulares, Espírito Santo (2013a) aponta algumas diferenças importantes na trajetória dessas duas sociedades, conforme se observa a seguir:

Na verdade, à data da independência, ocorrida em 1975, estes dois pequenos
Estados insulares de África enfrentavam os mesmos problemas para o seu
desenvolvimento. Isto é, as condições de partida eram basicamente as mesmas
nos dois países. É, contudo, importante salientar que São Tomé e Príncipe era
(e é) relativamente mais abundante em recursos naturais do que Cabo Verde.
Esse fato levou muitos, na época, a admitir que, ao contrário de Cabo Verde,
que tinha enorme escassez de recursos naturais, São Tomé e Príncipe
apresentava melhores potencialidades para se desenvolver. Porém, a partir dos
anos 90 do século XX, o desempenho de Cabo Verde em matéria de
desenvolvimento e, por consequência, do desenvolvimento humano, tornou-se
visível e relativamente mais importante do que em São Tomé e Príncipe, tal
como tem sido evidenciado nos dados estatísticos oficiais locais e no relatório
anual do desenvolvimento humano do PNUD e de outras fontes internacionais
(ESPÍRITO SANTO, 2013a, p. 44).

${ }^{38}$ No tópico sobre insularidade e microestados no Capítulo 2 da presente tese, foram abordadas muitas das vantagens dos PALOP insulares em relação aos continentais. 
Após a análise realizada sobre este tópico, tem-se como resultado a seguinte tabela:

Tabela 23 - Análise da variável insularidade/microestado nos PALOP

\begin{tabular}{|l|l|l|l|l|l|}
\hline Variável/ País & $\begin{array}{l}\text { Cabo } \\
\text { Verde }\end{array}$ & $\begin{array}{l}\text { São Tomé e } \\
\text { Príncipe }\end{array}$ & Moçambique & $\begin{array}{l}\text { Guiné- } \\
\text { Bissau }\end{array}$ & Angola \\
\hline $\begin{array}{l}\text { Insularidade } \\
\text { microestado }\end{array}$ & $\mathrm{S}$ & $\mathrm{S}$ & $\mathrm{N}$ & $\mathrm{N}$ & $\mathrm{N}$ \\
\hline
\end{tabular}

Fonte: Tabela elaborada pela autora.

\section{VIA 6: Direitos políticos e liberdades civis durante o período colonial}

Durante o período colonial, a ditadura portuguesa, que perdurou de 1926 a 1974, refletiu de maneira significativa o seu caráter autocrático na África. A repressão se desdobrava nas mais variadas dimensões, tais como se observa no excerto: "a pretensão do colonialismo português, marcado pelo conceito discriminatório do paternalismo legitimador, se escondia atrás da exploração económica e da imposição social e cultural que o acompanhava" (TESSAADORI, 2012, p. 115).

A supracitada discriminação era observada nos mais diferentes contextos da sociedade, tais como na diferença salarial entre europeus e nativos que atuavam no setor de mão-de-obra qualificada em Angola. Em algumas profissões, tais como os stokers (fogueiros), os europeus chegavam a ganhar quase 10 vezes mais do que africanos. $\mathrm{Na}$ tabela a seguir é possível identificar essas significativas diferenças, a saber:

Tabela 24 - Salários de trabalhadores qualificados em Angola em 1958 - base salarial em escudos (FERREIRA, 1974)

\begin{tabular}{lrrlrr}
\hline & Europeans & 'Natives' & & Europeans & 'Natives' \\
\hline Compositors, manual & 4,500 & 1,560 & Office workers & 2,500 & 1,800 \\
Carpenters & 3,120 & 1,690 & Stokers & 4,000 & 450 \\
Cooks & 3,334 & 500 & Drivers of & & \\
Servants & 1,500 & 450 & light vehicles & 2,500 & 1,200 \\
\multicolumn{2}{l}{} & & & \\
Source: Anuário Estatsstico de Angola & 1958, Luanda. & & \\
\hline
\end{tabular}

Fonte: Wages of skilled workers in Angola (1958) (in escudos) (FERREIRA, 1974, p. 36). 
A década de 1960 marcou um período de contestações em todo o mundo, e chegou à África de uma maneira idiossincrática. Inúmeros movimentos de libertação passaram a lutar pela autodeterminação dos povos africanos e pela independência dos territórios que ainda eram subjugados, conforme se observa no excerto a seguir:

\begin{abstract}
Os povos começaram a reencontrar os seus elementos de identidade iniciandose o processo de libertação cultural. A "explosão" das manifestações de todo o tipo (música, dança, escultura, literatura, etc.) revelaram o insucesso das diversas formas de repressão, demonstraram a capacidade de resistência, de preservação das identidades e confirmaram o orgulho que os povos possuem pelos respectivos patrimônios culturais" (MOSCA, 2001, p. 60).
\end{abstract}

No contexto das guerras coloniais, a ação autocrática intensificou-se ainda mais, conforme mencionado no tópico sobre o domínio colonial português deste capítulo. A expressiva gestão autocrática dos governos coloniais pode ser identificada no gráfico abaixo, que aborda o Índice de Democracia Eleitoral dos PALOP de 1900 a 2015. Nele, observa-se que os valores relacionados aos direitos políticos eram próximos de zero até o ano de 1974, a saber ${ }^{39}$ :

\footnotetext{
${ }^{39}$ O Índice de Democracia Eleitoral é denominado "Electoral Democracy Index" pelo V-DEM, sendo definido da seguinte maneira: "To what extent is the ideal of electoral democracy in its fullest sense achieved? Clarifications: The electoral principle of democracy seeks to embody the core value of making rulers responsive to citizens, achieved through electoral competition for the electorate's approval under circumstances when suffrage is extensive; political and civil society organizations can operate freely; elections are clean and not marred by fraud or systematic irregularities; and elections affect the composition of the chief executive of the country. In between elections, there is freedom of expression and an independent media capable of presenting alternative views on matters of political relevance. In the V-Dem conceptual scheme, electoral democracy is understood as an essential element of any other conception of (representative) democracy - liberal, participatory, deliberative, egalitarian, or some other. Aggregation: The index is formed by taking the average of, on the one hand, the weighted average of the indices measuring freedom of association (thick) (v2x_frassoc_thick), suffrage (v2x_suffr), clean elections (v2xel_frefair), elected executive (v2x_accex) and freedom of expression (v2x_freexp_thick); and, on the other, the five-way multiplicative interaction between those indices. This is half way between a straight average and strict multiplication, meaning the average of the two. It is thus a compromise between the two most well known aggregation formulas in the literature, both allowing (partial) "compensation" in one subcomponent for lack of polyarchy in the others, but also punishing countries not strong in one sub-component according to the "weakest link" argument. The aggregation is done at the level of Dahls sub-components (with the one exception of the non-electoral component). Note that data release 6 suggests an updated formula to create this index (release 1, 2, 3, 4 and 5 used a different, preliminary aggregation formula)" (VDEM, 2016).
} 


\section{Gráfico 7 - Índice de Democracia Eleitoral dos PALOP de 1900 a $2015^{40}$} (V-DEM, 2016)

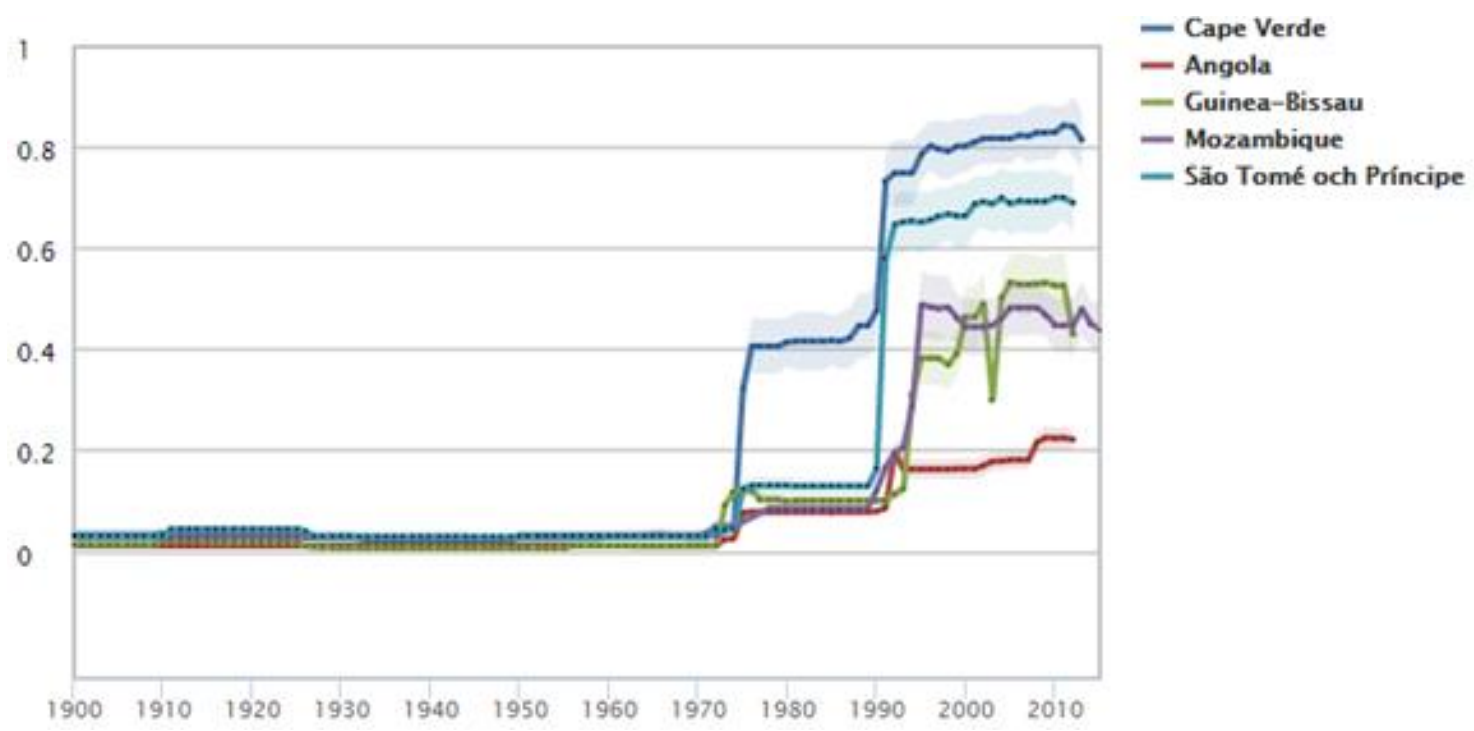

Fonte: V-DEM, 2016, s.p.

Da mesma forma, o Índice de Componentes Liberais ${ }^{41}$, que se relaciona às liberdades civis, também era muito reduzido no período colonial. Entretanto, esses valores se apresentam mais distintos do que o observado no índice anterior. De 1900 a 1974, São Tomé e Príncipe se apresenta como o PALOP com o maior valor de liberdade civil, distanciando-se expressivamente do segundo lugar, que era ocupado por Angola. Em seguida, Cabo Verde e Guiné-Bissau apresentavam valores muito semelhantes, sendo Moçambique classificado na pior colocação. Uma possível explicação para essa discrepância de resultados pauta-se no fato de que a repressão colonial se intensificou significativamente durante os conflitos armados, sendo que São Tomé e Príncipe foi o único dos PALOP que não participou ativamente das guerras coloniais. Apesar de Cabo Verde não ter tido conflitos armados no seu arquipélago, muitos dos seus cidadãos estavam profundamente ligados às lutas de independência que ocorriam na Guiné-Bissau.

41 O Índice de Componentes liberais é denominado "Liberal Component Index" pelo V-DEM, sendo definido da seguinte maneira: "To what extent is the liberal principle of democracy achieved? Clarification: The liberal principle of democracy emphasizes the importance of protecting individual and minority rights against the tyranny of the state and the tyranny of the majority. The liberal model takes a "negative" view of political power insofar as it judges the quality of democracy by the limits placed on government. This is achieved by constitutionally protected civil liberties, strong rule of law, an independent judiciary, and effective checks and balances that, together, limit the exercise of executive power" (V-DEM, 2016). 
Gráfico 8 - Índice de Componentes Liberais dos PALOP de 1900 a 2015 (VDEM, 2016)

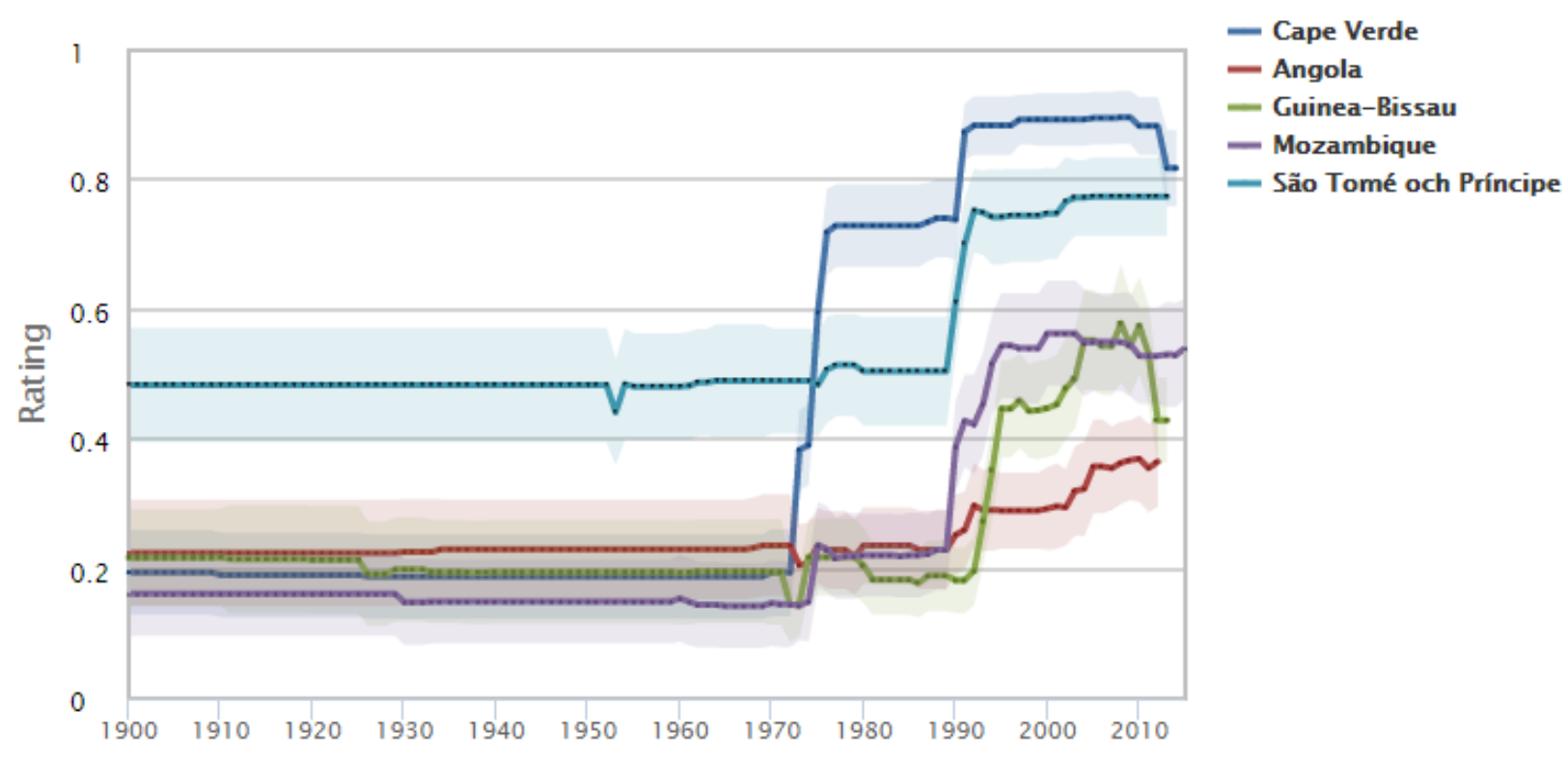

Fonte: V-DEM, 2016, s.p.

Conforme se observa na tabela abaixo, por meio da análise realizada foi possível observar que os direitos políticos e as liberdades civis de todos PALOP durante o colonialismo português eram muito reduzidos, a saber:

Tabela 25 - Análise dos direitos políticos e liberdades civis dos PALOP durante o regime colonial português

\begin{tabular}{|l|l|l|l|l|l|}
\hline Variável/ País & $\begin{array}{l}\text { Cabo } \\
\text { Verde }\end{array}$ & $\begin{array}{l}\text { São Tomé e } \\
\text { Príncipe }\end{array}$ & Moçambique & $\begin{array}{l}\text { Guiné- } \\
\text { Bissau }\end{array}$ & Angola \\
\hline $\begin{array}{l}\text { Direitos políticos } \\
\text { e liberdades civis } \\
\text { (t1) }\end{array}$ & $\mathrm{N}$ & $\mathrm{N}$ & $\mathrm{N}$ & $\mathrm{N}$ & $\mathrm{N}$ \\
\hline
\end{tabular}

Fonte: Tabela elaborada pela autora.

\section{VIA 7: Recursos naturais}

Por serem ilhas vulcânicas, Cabo Verde e São Tomé e Príncipe não possuem recursos naturais, sendo o interesse português nos arquipélagos impulsionado primordialmente pela localização estratégica de ambos. Já a Guiné-Bissau também não possui recursos naturais significativos, sendo a riqueza do país produzida principalmente por meio da agricultura. Recursos naturais tais como gás natural e carvão foram 
descobertos recentemente em Moçambique, sendo que por esse motivo, eles ainda são relativamente pouco explorados no país, apesar do crescente investimento das empresas multinacionais para extrai- $\operatorname{los}^{42}$. Considerando esse cenário específico, tem-se que a classificação dessa variável será negativa para o país no âmbito da tabela a seguir.

Contudo, os recursos naturais de Angola são explorados há muito tempo. Seja o ouro, o diamante ou o petróleo, o país se constituiu como uma importante fonte de receita para o Império Português e, posteriormente, para os líderes que assumiram o governo no pós-independência. De acordo com o Banco Mundial (2016b), atualmente são conhecidos somente $40 \%$ dos recursos naturais angolanos, fenômeno que exprime o grande potencial mineiro do seu território, notadamente de diamantes. Apesar do significativo impacto da mineração, o maior recurso do país é o petróleo, que foi responsável por aproximadamente $97 \%$ das exportações do país na última década (BANCO MUNDIAL, 2016b). No gráfico abaixo, é possível observar o papel que a rentabilidade do petróleo possui em relação ao PIB no contexto angolano, a saber:

\section{Gráfico 9 - Porcentagem da rentabilidade do petróleo em relação ao PIB nos PALOP (BANCO MUNDIAL, 2016)}

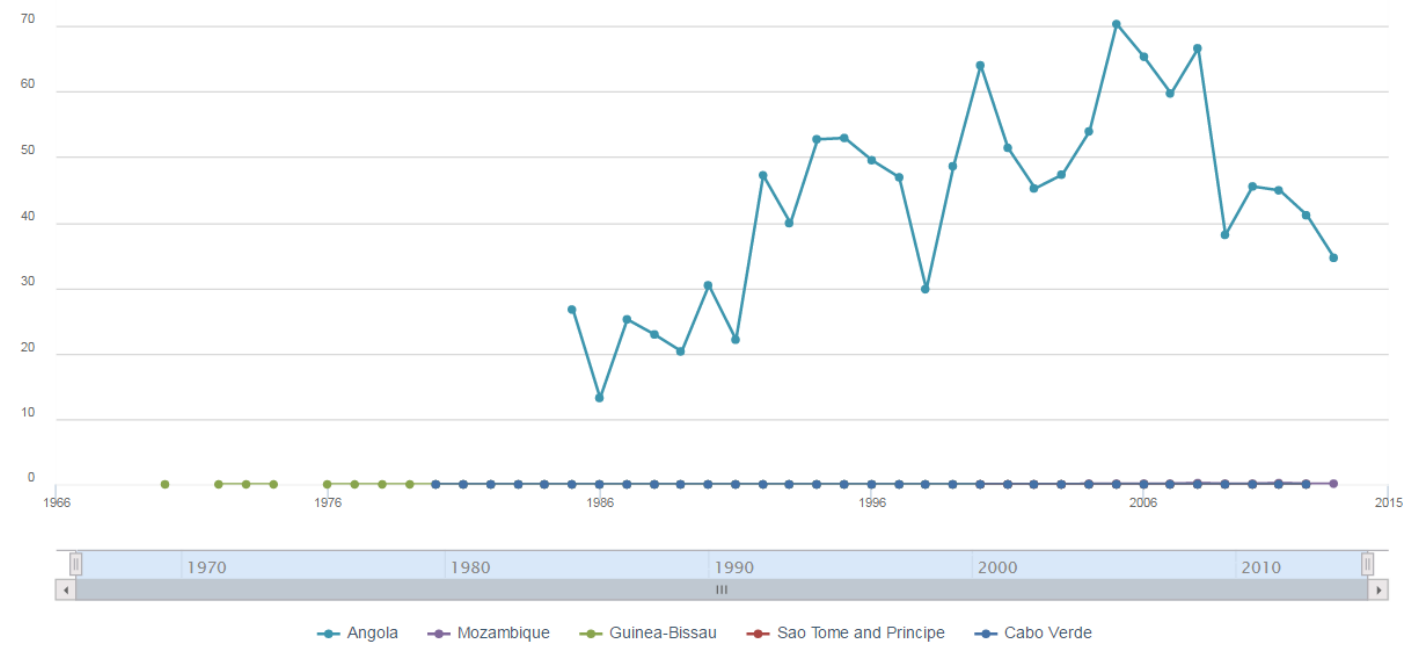

Fonte: BANCO MUNDIAL, 2016b, s.p.

42 Nesse sentido, Zeca (2013) afirma que "Recentemente na zona austral e oriental de África estão sendo descobertos recursos energéticos estratégicos com intervenção de multinacionais poderosas. Em Moçambique, a Empresa Anadarko anunciou quatro descobertas de gás natural na Bacia do Rovuma em quatro prospectos [...] Em Moçambique, a exploração de recursos energéticos, gás natural e carvão mineral, tem verificado um rápido desenvolvimento, nos últimos anos, como resultado da exploração de abundantes reservas de carvão mineral e gás natural, por várias multinacionais, como são os casos da brasileira Vale (Moatize), a australiana RioTinto (Benga e Zambeze), as britânicas Ncondezi Coal Company (Ncondezi) e Beacon Hill Resources - Minas de Moatize (Moatize), a JSP Lda Índia (Changara), a Eta Star do Dubai (Moatize), a ENRC (Cahora Bassa), Minas de Revubuè - Talbot/Nippon Steel (Revubué), Sasol (Pande e Temane)" (ZECA, 2013, p. 04). 
Nesse ínterim, tem-se que no âmbito da variável relativa à presença de recursos naturais nos PALOP, somente Angola apresenta um resultado positivo, conforme se expressa na tabela a seguir:

Tabela 26 - Análise da exploração de longo prazo dos recursos naturais n os PALOP

\begin{tabular}{|l|l|l|l|l|l|}
\hline Variável/ País & $\begin{array}{l}\text { Cabo } \\
\text { Verde }\end{array}$ & $\begin{array}{l}\text { São Tomé e } \\
\text { Príncipe }\end{array}$ & Moçambique & $\begin{array}{l}\text { Guiné- } \\
\text { Bissau }\end{array}$ & Angola \\
\hline Recursos naturais & $\mathrm{N}$ & $\mathrm{N}$ & $\mathrm{N}$ & $\mathrm{N}$ & $\mathrm{S}$ \\
\hline
\end{tabular}

Fonte: Tabela elaborada pela autora.

\section{VIA 8: Diversidade étnica}

Para Chabal (1996), nenhum outro grupo de países representa tão bem a complexidade e diversidade do continente africano quanto os PALOP. Esse cenário de heterogeneidade pode ser observado no âmbito da variedade étnica desses países, nos quais cada realidade exprime uma história e uma trajetória própria, conforme será analisado nos parágrafos a seguir.

Cabo Verde possui o que Chabal (1996) denomina de sociedade crioula. Por ter sido um ponto de abastecimento e um importante entreposto de escravos durante os séculos de dominação colonial portuguesa, a população do país se formou em bases multiétnicas pautadas primordialmente na miscigenação entre colonos portugueses e escravos. Esse conjunto único fez com que $71 \%$ da população atualmente seja considerada crioula, $28 \%$ de outros povos nativos e $1 \%$ de europeus. Apesar do português e constituir como o idioma oficial, a maioria do país se comunica em crioulo caboverdiano (EPORTUGUESEa, 2011).

Já São Tomé e Príncipe também possui uma sociedade majoritariamente crioula, mas de um tipo diferente da cabo-verdiana, em função da sua maior semelhança cultural e social com a realidade africana (CHABAL, 1996). Desde 1470, ano do descobrimento de São Tomé e Príncipe, um vasto conjunto de grupos e etnias habitaram o país, o que fez com que sua população se apresentasse atualmente com origens diversas, sendo composta por quatro grupos principais, a saber: a) fôrros (descendentes dos escravos que foram 
alforriados com o fim da escravidão); b) angolares (descendentes dos escravos de Angola); c) mestiços (descendentes de portugueses e de escravos advindos de diversas localizações na África) e d) serviçais (empregados contratados moçambicanos, angolanos e cabo-verdianos que temporariamente trabalhavam nas roças são-tomenses) (EPORTUGUESEb, 2011). No espectro linguístico, assim como Cabo Verde, o português é o único idioma oficial do país, ressaltando que grande parte da população se comunica em crioulo são-tomense, angolar ou principense.

Nos PALOP continentais, a questão étnica se mostrou muito mais complexa do que a observada nos arquipélagos supracitados. Em Moçambique, apesar do português se apresentar como o único idioma oficial, outras 43 línguas são faladas. Enquanto o norte do país apresentou-se mais tradicional, conservando costumes como uma configuração matrilinear e seminômade, a sua parte meridional sofreu maior influência da cultura e religião portuguesas. Na contemporaneidade, os seus principais grupos étnicos são: a) Makhuwa (constituem 37\% da população, são originários do norte do país e caracterizamse por serem majoritariamente animistas e por falarem o idioma Makua); b) Tsonga (constituem $25 \%$ da população, são originários do sul e do centro do país, assimilaram a religião cristã e, tradicionalmente, são poligâmicos); c) Makonde (constituem $10 \%$ da população, são originários do extremo norte do país, sendo cristãos e muçulmanos) e os d) Ndau (constituem 9\% da população, são originários da região central do país e possuem uma grande diversidade étnica, advinda da mistura dos guerreiros da Suazilândia com os Manika, Barwe e Tewe) (EPORTUGUESEb, 2011).

Assim como Moçambique, a diversidade étnica da Guiné-Bissau possui um caráter secular. Integrante do maior império medieval africano, o Império Mali de Mansa Mussa (séculos XIII e XIV), a Guiné-Bissau só passou a ser completamente dominada pelos portugueses no século XIX. A pluralidade da sua construção histórica fez com que o país apresentasse uma significativa heterogeneidade étnica, com cinco grupos principais, a saber: a) Balante (constituem 30\% da população, são originários da região central do país, sendo cristãos, muçulmanos e animistas); b) Fulani (constituem 20\% da população, são originários do norte do país, sendo o maior grupo nômade do planeta); c) Manjakos (constituem 14\% da população, são originários das ilhas de Pecixe e Jata e da região central do país e caracterizam-se por serem primordialmente animistas, dedicandose à agricultura); d) Mandinka (constituem 13\% da população, são originários do Império 
Mali, sendo muçulmanos e constituindo um dos maiores grupos étnicos do continente, tiveram 30\% dos seus membros enviados como escravos para as Américas) e e) Papel (constituem 7\% da população, são originários das regiões costeiras do país, sendo um dos povos mais impactados pelo tráfico de escravos). Além desses cinco grupos principais, destacam-se os Bassari, os Jola, os Mankanya e os Bijagós (EPORTUGUESEc, 2011).

Ao analisar o caso de Angola, tem-se que o país possui seis idiomas oficiais (português, kikongo, kimbundu, mbunda, chokwe e oshiwambo) e 42 línguas faladas (destaca-se que essas línguas não são escritas). A sua população é primordialmente de origem Bantu, dividida em três principais segmentos étnico-linguísticos, a saber: a) Ovimbundu (constituem 37\% da população, são originários da costa sudoeste do país e possuem relativamente mais recursos financeiros do que os outros grupos); b) Kimbundu ou Mbundu (constituem 25\% da população, são originários do noroeste e centro-norte do país e a sua cultura tradicional se baseia em comunidades matriarcais e utilizam o idioma Mbundu, falado por mais de $30 \%$ da população) e c) Bakongo (constituem $13 \%$ da população, são originários do Congo e suas tribos sofreram forte influência dos missionários católicos, sendo atualmente bastante fragmentadas) (EPORTUGUESEa, 2011).

Após a análise realizada, tem-se que Cabo Verde e São Tomé e Príncipe apresentam uma relativa homogeneidade étnica, considerando que a composição das suas sociedades é primordialmente crioula. Por outro lado, Moçambique, Guiné-Bissau e Angola podem ser considerados Estados com maior heterogeneidade étnica, religiosa e cultural. Apesar de não ter sido observado um quadro de clivagem étnica em nenhum dos PALOP, infere-se que a composição mais homogênea das sociedades cabo-verdiana e são tomense pode ter contribuído para a maior estabilidade desses países ao longo das suas trajetórias históricas. Nesse ínterim, é possível construir a seguinte tabela:

Tabela 27 - Análise da diversidade étnica dos PALOP

\begin{tabular}{|l|l|l|l|l|l|}
\hline Variável/ País & $\begin{array}{l}\text { Cabo } \\
\text { Verde }\end{array}$ & $\begin{array}{l}\text { São Tomé e } \\
\text { Príncipe }\end{array}$ & Moçambique & $\begin{array}{l}\text { Guiné- } \\
\text { Bissau }\end{array}$ & Angola \\
\hline Diversidade étnica & $\mathrm{N}$ & $\mathrm{N}$ & $\mathrm{S}$ & $\mathrm{S}$ & $\mathrm{S}$ \\
\hline
\end{tabular}

Fonte: Tabela elaborada pela autora. 


\title{
VIA 9: Guerras de independência
}

\author{
Há sempre a lembrança \\ De um olhar a sangrar \\ De um soldado perdido \\ Em terras do Ultramar \\ Por obrigação \\ Aquela missão \\ Combater a selva sem saber por quê \\ E sentir o inferno de matar alguém \\ E quem regressou \\ Guarda a sensação \\ Que lutou numa guerra sem razão... \\ Sem razão... sem razão... \\ Música "Aquele Inverno" de Miguel Ângelo e Fernando Cunha
}

Conforme citado no tópico sobre o domínio português, a realidade das colônias portuguesas foi muito diferente da observada na maioria das outras colônias africanas. Isso se explica porque o governo de Lisboa não aceitou negociar a independência com os movimentos de libertação, fomentando a instauração de guerras duradouras nos três PALOP continentais.

O pós-Segunda Guerra Mundial impulsionou um sentimento de autodeterminação dos povos africanos, que se moldou pautado em aspectos nacionalistas ao redor de todo o continente. O movimento anticolonial fortaleceu-se na África lusófona somente na década de 1950, influenciado fortemente pela Conferência de Bandung. As suas raízes remontam a origens diversas, tais como a criação do Centro de Estudos Africanos (CEA) em Portugal, no qual estudantes originários das diferentes colônias portuguesas discutiam de maneira progressista e politizada variadas questões relacionadas à sua terra natal. Entre eles, encontravam-se Agostinho Neto, Amílcar Cabral, Marcelino dos Santos, Mário de Andrade, Aquino de Bragança, Lúcio Lara, Vasco Cabral e Noémia de Sousa. Para Fraga (2014), a importância desse grupo é observada no seguinte excerto:

Pode dizer-se que o papel dos intelectuais africanos, formados em Portugal e com ligações aos movimentos anticoloniais existentes nas suas terras de origem, foi fundamental para gerar a tentativa de entendimento comum de forma a que a luta política e armada (mais tarde) tivesse uma articulação mínima em todas as colónias portuguesas. (FRAGA, 2014, p. 12). 
Os grupos de vanguarda que clamavam pela independência apresentavam algumas características específicas, no qual o seu perfil se distinguia da porção majoritária da sociedade, a saber: "as primeiras elites independentistas germinaram entre o reduzido setor assimilado, muitas vezes mestiço, de Angola e Moçambique. Na Guiné-Bissau foram os cabo-verdianos na sua maioria os primeiros a criar movimentos autonomistas" (PINTO, 2001, p. 35).

Em uma entrevista concedida à Edlena Barros (2014), Leonel Mário D’Alva, criador do Comitê de Libertação de São Tomé e Príncipe ${ }^{43}$, afirmou que a libertação dos outros países na África inspirava a luta contra a opressão colonial no arquipélago, principalmente depois do Massacre de Batepá em 1953. Nesse contexto, ele cita a independência de Gana, a saber:

\begin{abstract}
Ainda me recordo que quando o Gana se tornou independente, em 1957, Kwame Nkrumah, que era o Presidente naquela altura, fez uma declaração dizendo que o Gana não se consideraria independente enquanto os outros países africanos não fossem independentes. Isso foi uma das coisas que me entusiasmou muito. E disse para mim próprio: Se o Gana se tornou independente porque que é que nós não? (BARROS, 2014)
\end{abstract}

A insatisfação da população local em relação à administração portuguesa ocorreu em todos os PALOP, fomentando inúmeras manifestações contra o governo colonial. A criação de organizações políticas como o Partido da Luta Unida dos Africanos de Angola (PLUA) em 1953 e do Partido Comunista Angolano (PCA) ${ }^{44}$, em 1955, evidenciou que, na concepção de Fraga (2014), a conscientização popular anticolonial em Angola, apesar de tardia, ganhou força do organicidade ao longo do tempo, a saber:

[...] embora com algum atraso em relação às colónias britânicas e francesas, Angola foi rica em tomada de consciência da necessidade de luta contra o colonialismo. Por vezes, percebe-se que não existia, de facto, uma concepção de independência nacional (se existisse, era de estranhar, dadas as diferenças étnicas em presença). Contudo, parece ter sido uma certa doutrinação marxista que conduziu, em alguns casos — nomeadamente à volta do MPLA —, à superação das diferenças para encontrar as plataformas mínimas de entendimento (FRAGA, 2014, p. 11).

\footnotetext{
${ }^{43}$ Em 1972, o Comitê de Libertação de São Tomé e Príncipe passou a se chamar Movimento de Libertação de são Tomé e Príncipe (MLSTP), sendo o seu escritório localizado no Gabão e tendo como secretáriogeral Pinto da Costa (PINTO, 2001).

${ }^{44}$ O MPLA foi fundado em 1956 como uma aglutinação do PLUA e do PCA (FRAGA, 2014).
} 
A recusa do governo português em negociar a independência das colônias fez com que, no dia 4 de fevereiro de 1961, se iniciasse a luta armada na África lusófona. Esse primeiro conflito ocorreu em Angola, com o ataque do MPLA à Cadeia de São Paulo e às suas forças policiais em Luanda. Já no dia 15 de março, a UPA, posteriormente denominada FNLA (1962), realizou chacinas em algumas fazendas agrícolas no norte do país, causando centenas de mortes. A violência utilizada por Portugal para reprimir os grupos revolucionários ficou evidenciada desde as primeiras contestações. Nesse contexto, os pesquisadores do Centro de Investigação para Tecnologias Interativas (CITI) argumentaram que, "no ano de 1961, Salazar irá proferir a máxima legitimadora da sua posição relativamente às rebeliões que se desencadeavam nas possessões portuguesas: "Para Angola, imediatamente e em força"”' (CITI, 2016, p. 01).

A luta por meio de guerrilhas ${ }^{45}$ aconteceu nos anos posteriores, sendo esse um dos principais fatores que explicam o sucesso militar dos grupos insurgentes contra os portugueses. Contudo, desde o início do confronto, a fragmentação interna de Angola, muitas vezes ligada à representação étnica, fez com que determinados movimentos ganhassem preponderância no escopo de um espaço geográfico e de uma população específicos, a saber:

O MPLA, pelas suas tendências marxistas, procurava suplantar diferenças étnicas e ser um partido mais cosmopolita, ainda que a sua verdadeira base de implantação inicial tenha sido junto da etnia mbundo cuja área de ocupação geográfica se desenvolvesse na faixa Luanda - Malange. Pelo contrário, a FNLA limitava-se quase exclusivamente à etnia bacongo, ocupando o Noroeste de Angola (FRAGA, 2014, p. 21).

Por se encontrar inserida em no contexto da Guerra Fria, os movimentos que almejavam a libertação colonial na guerra angolana recebiam apoio tanto dos EUA quanto da URSS, que visavam a trazer os países recém-criados para a sua órbita de influência. No caso de Angola, tem-se que: "os EUA auxiliavam a UPA e o MPLA era simpatizante

\footnotetext{
${ }^{45}$ Fraga (2014) descreve a guerra de guerrilhas na África da seguinte maneira: "A guerra praticada pelo guerrilheiro tinha mesmo essa principal característica: bem camuflado na folhagem existente na floresta, batia e fugia de imediato para muito longe, aproveitando a proteção que as diferenças de nível do terreno lhes proporcionavam. Quase nunca se expunha e furtava-se sempre à luta frontal" (FRAGA, 2014, p. 19). Para o autor, esse tipo de "guerra subversiva", que ocorreu em todos os PALOP continentais, pauta-se grandemente no apoio das populações locais aos guerrilheiros.
} 
dos ideais defendidos na URSS, da qual recebia apoios, no início pouco abundantes em material, mas abastados em formação ideológica” (FRAGA, 2014, p. 13).

Os desentendimentos dos grupos que lutavam pela independência no país trouxeram inúmeras vantagens para os portugueses durante a guerra. Paralelamente ao conflito contra Portugal, o MPLA, de Agostinho Neto, e a FNLA, de Holden Roberto, enfrentaram-se no norte do país, sendo o último grupo praticamente extinto em 1965. Além disso, em 1964 um novo ator foi inserido no teatro bélico de Angola: a UNITA. Criada por Jonas Savimbi, que era um dos homens de confiança de Holden Roberto, o partido político era baseado primordialmente na etnia ovimbundo, localizada na parte central do país, bem como nas populações meridionais e orientais do território angolano. Desde a sua constituição, a UNITA representava uma força de oposição ao MPLA, fator que ajuda a explicar os desdobramentos políticos no país durante todo o período do pósindependência.

A guerra em Angola perdurou de 1961 a 1975. A independência angolana ocorreu com o Acordo de Alvor, assinado com Portugal em janeiro de 1975. Contudo, o reconhecimento português ocorreu somente no ano seguinte, fazendo de Angola a primeira ex-colônia lusófona na África a lutar pela independência e a última a efetivamente consegui-la. Em 1975, Agostinho Neto assumiu o poder do país sob a égide do MPLA, iniciando um novo ciclo na história do país recém-criado (AFONSO, 2009).

No contexto das reivindicações independentistas na Guiné-Bissau, tem-se que em 1955 surgiu o Movimento para a Independência Nacional da Guiné (MING), que apresentou uma curta existência. Logo depois, criou-se o Partido Africano para a Independência (PAI), que foi substituído pelo PAIGC em 1960. O líder do partido era Amílcar Cabral, um cabo-verdiano que, enquanto estudara em Portugal, fazia parte do mencionado grupo do CEA. Fraga (2014) afirma que o seu pensamento se pautava em ideais próximos aos marxistas, sendo baseado em três vertentes principais, a saber: a) pan-africanismo, b) construção de uma via socializante de justiça social na África e c) construção de um Estado que unisse Guiné-Bissau a Cabo Verde.

Antes do início da guerra, Amílcar Cabral fez inúmeros pedidos ao governo português para que fossem realizadas negociações direcionadas para a independência guineense e cabo-verdiana. Contudo, o posicionamento irredutível do Estado Novo em 
manter o ultramar português fez com que a guerra colonial na Guiné-Bissau começasse em 1963, com um ataque ao quartel de Tite, no sul de Bissau. Assim como ocorrido em Angola, o conflito também foi realizado por meio de guerrilhas nas matas e terrenos alagados do país. Destaca-se, nesse ínterim, que o PAIGC era um grupo muito organizado e detinha o apoio dos seus vizinhos, representados pela Guiné-Conacri e pelo Senegal. No espectro étnico, os balantas e os mandinkas (mandingas) apoiavam o PAIGC, enquanto os fulas auxiliavam os portugueses (FRAGA, 2014).

Nesse cenário, o auxílio advindo dos países comunistas foi fundamental para manter e aprimorar a estrutura militar e logística do PAIGC durante o conflito, a saber:

\begin{abstract}
Dado a existência de uma estrutura hierárquica muito bem definida e um objetivo claro, servido por uma ideologia aceite por todos, o PAIGC pôde, logo desde a sua fase de propaganda e implantação no terreno, receber auxílio dos países comunistas, quer formando quadros militares, quer fornecendo armamento e equipamento. Nos aquartelamentos (bases) do partido, ao mesmo tempo que se preparava militarmente o guerrilheiro dava-se-lhe a instrução mínima para ele sair do obscurantismo cultural em que até aí havia vivido e doutrinava-se o combatente para que fosse um elemento de propaganda ativo no contato com as populações do interior do território. Cuba foi um dos Estados socialistas que mais auxiliou o partido de Cabral, em especial a partir de 1965. Mais tarde, também alguns países europeus, nomeadamente a Suécia, deram o seu contributo fornecendo bens que possibilitavam transformar a vida das bases em verdadeiros centros de apoio logístico das forças empenhadas na luta armada (FRAGA, 2014, p. 48).
\end{abstract}

A cada ano, os insurgentes ganhavam maior controle sobre o complexo território guineense. Apesar dos esforços do general Antônio Spínola, as Forças Armadas portuguesas perdiam um gradativo espaço de ação no complexo espectro de guerrilhas. Depois de quase 10 anos de conflito, em 1972 a Comissão Especial para a Descolonização das Nações Unidas visitou a Guiné-Bissau e formulou um relatório reconhecendo o PAIGC como o legítimo representante político do país. Como consequência, na $28^{\mathrm{a}}$ sessão da ONU, Portugal foi considerado ocupante ilegítimo do território guineense. Nesse contexto, os movimentos de libertação tornaram-se observadores na instituição (FRAGA, 2014).

No ano de 1973, após a morte de Amílcar Cabral, o PAIGC proclamou a independência da Guiné-Bissau nas Colinas de Boé, sendo a soberania do país internacionalmente reconhecida por diversos Estados. Mesmo depois desse fenômeno, Portugal continuou a guerra, já sabendo que as chances de vitória seriam mínimas. Contudo, no ano seguinte, ao governo português não restou alternativa a não ser 
reconhecer o país como independente. Nesse ínterim, Guiné-Bissau entrou para a história como a primeira ex-colônia da África lusófona a ter a sua independência reconhecida pela ex-metrópole. Mesmo o PAIGC tendo lutado pela independência da Guiné e de Cabo Verde, a soberania do arquipélago ocorreu de maneira separada, envolvendo acordos específicos com Lisboa que se desdobraram no reconhecimento da independência caboverdiana somente em 1975 (AFONSO, 2009).

Moçambique foi a última colônia africana a iniciar o conflito armado contra as Forças Armadas portuguesas. O primeiro partido baseado na libertação colonial era representado pelo Maconde African National Union (MANU) ${ }^{46}$, fundado na Tazânia. A junção do MANU com a União Nacional Africana de Moçambique e com a União Democrática Nacional de Moçambique formou a FRELIMO, que fornecia unidade e identidade aos membros desses outros grupos que atuavam de maneira fragmentada, constituindo "um único movimento no qual todos se reconhecessem" (FRAGA, 2014, p. 12).

A conciliação das diversas clivagens sociais do país era articulada pelo líder da FRELIMO, Eduardo Mondlane, que foi assassinado em 1969. Seu sucessor foi Samora Machel, que fortaleceu o partido tanto militar quanto diplomaticamente. O início da guerra ocorreu em 1964, com diversos ataques da FRELIMO, tais como o direcionado ao posto do Chai, em Cabo Delgado. No início do conflito as armas vinham da Tanzânia e duas etnias se colocaram contra os portugueses, os Macondes e os Nianjas. Assim como o conflito angolano, na guerra colonial em Moçambique a tática utilizada foi a de guerrilhas no campo, com lutas prolongadas e desgaste do inimigo. Além disso, instaurou-se a "política de aldeamento", na qual um grande contingente populacional encontrava-se protegido por uma milícia específica, visando a impedir a propaganda e o apoio social aos portugueses (FRAGA, 2014).

Apesar da experiência em Angola, as Forças Armadas de Portugal insistiram em utilizar métodos tradicionais de guerra para combater os grupos guerrilheiros em Moçambique. Como resultado, a FRELIMO se fortalecia cada vez mais, criando inúmeros espaços de controle no território. Como resposta a um conflito inconstante e imprevisível, o Exército português realizou muitas chacinas e massacres de civis, tendo

\footnotetext{
${ }^{46}$ Posteriormente, o partido passou a se chamar Mozambique National African Union.
} 
como exemplo o antológico ataque a Wiriamu ${ }^{47}$, que ganhou grande repercussão na imprensa internacional com as denúncias do padre Adrian Hastings. Nesses cenários extremos, a PIDE/DGS (polícia política portuguesa) era implacável com aqueles que se posicionassem contra as ações do Estado, realizando inúmeras prisões na África (FRAGA, 2014).

A FRELIMO lutou durante 10 anos pela libertação do país, até que o acordo pela independência ocorresse em 1974, em Lusaka, sendo a independência reconhecida por Portugal no dia 25 de junho de 1975. A partir de então, Samora Machel começou o governo provisório, no qual a FRELIMO permanece no poder initerruptamente até os dias atuais.

Na tabela abaixo, é possível observar a dimensão da guerra colonial, que se intensificou com o passar dos anos. Nesse contexto, a década de 1970 foi o momento no qual Portugal atingiu o seu limite crítico de mobilização bélica na África. Além disso, nota-se que a amplitude de recursos empenhados no conflito angolano foi significativamente maior quando comparada aos confrontos corridos em Moçambique ou Guiné-Bissau (AFONSO, 2009). Somente no âmbito do Exército português, os efetivos militares nas três arenas da guerra colonial africana foram os seguintes:

${ }^{47}$ Em Wiriamu ocorreu o massacre de cinco aldeias com a morte de pelo menos 385 pessoas em dezembro de 1972 . 
Tabela 28- Quadro de efetivos do Exército de 1961 a 1973 (AFONSO, 2009)

\begin{tabular}{|l|r|r|r|r|}
\hline & Angola & \multicolumn{1}{|c|}{ Guiné } & Moçambique & Totais Exército \\
\hline 1961 & 33.400 & 4.700 & 11.200 & 49.300 \\
\hline 1962 & 44.900 & 5.100 & 11.900 & 61.900 \\
\hline 1963 & 47.400 & 9.600 & 14.200 & 71.200 \\
\hline 1964 & 52.500 & 15.200 & 18.000 & 85.700 \\
\hline 1965 & 57.000 & 17.300 & 22.900 & 97.200 \\
\hline 1966 & 55.800 & 20.800 & 30.600 & 107.200 \\
\hline 1967 & 57.400 & 21.600 & 34.700 & 113.700 \\
\hline 1968 & 58.200 & 22.800 & 36.600 & 117.600 \\
\hline 1969 & 55.600 & 26.600 & 39.100 & 121.300 \\
\hline 1970 & 55.200 & 26.800 & 38.700 & 120.700 \\
\hline 1971 & 62.100 & 29.200 & 44.500 & 135.800 \\
\hline 1972 & 60.300 & 30.000 & 46.700 & 137.000 \\
\hline 1973 & 65.600 & 32.000 & 51.500 & 149.100 \\
\hline
\end{tabular}

*Nesse contexto, destaca-se que, no final da guerra, havia outros 20.000 membros da Marinha e da Força Aérea portuguesa em combate.

Fonte: AFONSO, 2009, s.p.

De acordo com FRAGA (2014), o Exército da metrópole sofreu uma grande africanização no decorrer das guerras de independência em função do esgotamento da possibilidade de recrutamento militar em Portugal nos anos finais do conflito. Nesse contexto, o autor afirma que:

Se o conflito em África começou com a utilização de baixos contingentes africanos, que foram crescendo a um ritmo suave até quase ao final dos anos 60 , verifica-se que é no começo dos anos 70 que se dá um acréscimo brutal na africanização da tropa, sinal de que Portugal estava a chegar à exaustão, tanto mais visível se a compararmos com os números faltosos. Seletivamente, a africanização do continente fez-se mais cautelosa na Guiné e em Moçambique onde se criaram corpos especiais de combate para neles incorporar forças capazes de suprirem com vantagem as tropas de quadrícula metropolitana que iam faltando (FRAGA, 2014, p. 73).

A maior quantidade de mortes do contingente militar português ocorreu em Angola, seguido por Moçambique e Guiné-Bissau. Conforme se observa na tabela abaixo, nos 13 anos de conflito, as baixas do Exército da metrópole foram de 8.590 pessoas, sendo de 5.797 combatentes advindos de Portugal e de 2.793 militares de origem africana, a saber: 
Tabela 29 - Quadro das baixas por morte do Exército de Portugal nas três colônias africanas (FRAGA, 2014)

\begin{tabular}{|l|r|r|r|r|r|r|r|r|r|r|}
\hline \multicolumn{1}{|c|}{ Colónia } & \multicolumn{2}{|c|}{ Em combate } & \multicolumn{2}{c|}{$\begin{array}{c}\text { Acidente com } \\
\text { arma }\end{array}$} & \multicolumn{2}{c|}{$\begin{array}{c}\text { Acidente de } \\
\text { viação }\end{array}$} & \multicolumn{2}{c|}{ Outras causas } & \multicolumn{2}{c|}{ Soma } \\
\hline Recrutamento & Metrop. & Afric. & Metrop. & Afric. & Metrop. & Afric. & Metrop. & Afric. & Metrop. & Afric. \\
\hline Angola & 1.098 & 208 & 240 & 104 & 608 & 252 & 488 & 260 & 2.434 & 824 \\
\hline Guiné & 985 & 255 & 170 & 37 & 135 & 18 & 309 & 161 & 1.599 & 471 \\
\hline Moçambique & 1.027 & 454 & 130 & 104 & 244 & 223 & 363 & 417 & 1.764 & 1.198 \\
\hline Total & 3.110 & 917 & 540 & 245 & 987 & 493 & 1.160 & 838 & 5.797 & 2.493 \\
\hline
\end{tabular}

Fonte: FRAGA, 2014, p. 90. O autor menciona que retirou essés dados da obra: Resenha Histórico-Militar das Campanhas de África (1961 - 1774), pp. 264-266.

No contexto do que fora mencionado no espectro da guerra colonial, tem-se que os custos do confronto foram muito altos para Portugal, tanto na perspectiva financeira quanto na humana. Os três cenários de atuação bélica exigiram um contingente cada vez maior de suprimentos, suscitando um cenário de grande fragilidade doméstica (CITI, 2016). Como exemplo, têm-se números surpreendentes, tais como a mobilização de 1,4 milhão de soldados portugueses para o conflito, de acordo as informações presentes no seguinte excerto:

As três frentes de guerra provocaram fortes abalos nas finanças do Estado, desgastando simultaneamente as forças armadas, ao mesmo tempo que colocava Portugal cada vez mais isolado no panorama político mundial. A nível humano, as consequências foram trágicas: um milhão e quatrocentos mil homens mobilizados, nove mil mortos e cerca de trinta mil feridos, além de cento e quarenta mil ex-combatentes sofrendo distúrbios pós-guerra. A acrescentar a estes números há ainda que mencionar as não contabilizadas vítimas civis de ambas as partes.

O conflito não terá solução através de meios pacíficos ou militares, mas apenas por meios políticos e diplomáticos empreendidos após 1974 (CITI, 2016, p. 01)

Fortuna (1985) sintetiza o alto preço pago pela resistência de Portugal à descolonização no seguinte excerto:

[...] quanto mais débil economicamente o país colonial, maiores são as resistências que oferece à descolonização. Não pode, no entanto, resistir, como se disse, sem uma moeda de troca em que se paguem os custos derivados dessa resistência. Pode-se mesmo chegar a ter de pagar o custo de 13 anos de guerra colonial, gastar-se nela quase metade no orçamento anual, endividar progressivamente um país, reforçar os elos de dependência externa, mobilizar quase 15 por cento dos cidadãos em idade militar. Enfim, pode mesmo chegarse ao ponto de empenhar uma nação e um regime numa causa historicamente perdida (FORTUNA, 1985, p. 496). 
Mesmo não tendo vivenciado conflitos armados em seu território, Cabo Verde abrigava entre os anos de 1935 e 1974 o Tarrafal, que consistia na prisão política do governo colonial português. Localizado a 67 quilômetros da sua capital, a cidade de Praia, o referido presídio recebeu combatentes advindos dos movimentos de libertação em Guiné-Bissau, Cabo Verde, Angola e Portugal (TVBRASIL, 2015).

Conforme mencionado anteriormente, não houve Guerra nos PALOP insulares porque não era possível estabelecer conflitos nos seus territórios em função da sua insularidade, que impedia a realização de guerrilhas. Para Penna Filho (2015), isso se explica porque o reduzido tamanho do território dos arquipélagos faria com que as tropas portuguesas ganhassem o conflito facilmente, tendo em vista que as ilhas não permitiriam um combate por meio de táticas operacionais difusas em campos abertos. São Tomé e Príncipe teve um incipiente movimento de resistência, sendo que a sua independência ocorreu primordialmente por questões externas, a saber:

Com o caso das pequenas ilhas de São Tomé e Príncipe entramos claramente nas independências que foram mais uma consequência da transição democrática em Portugal e do surto global de descolonização do que a luta organizada de um nacionalismo autóctone ou de pressão internacional que tivesse de algum modo perturbado a metrópole (PINTO, 2001, p. 71).

Após a análise realizada, tem-se que as guerras de independência foram observadas somente nos PALOP continentais, conforme se verifica na tabela a seguir. É importante destacar que esses conflitos representam uma variável importante para compreender a democratização dos PALOP na década de 1990, tendo em vista que os seus desdobramentos exercerão grande influência no âmbito social, político e econômico desses países no pós-independência.

Tabela 30 - Análise da presença de guerras de independência dos PALOP no pósindependência

\begin{tabular}{|l|l|l|l|l|l|}
\hline Variável/ País & $\begin{array}{l}\text { Cabo } \\
\text { Verde }\end{array}$ & $\begin{array}{l}\text { São Tomé e } \\
\text { Príncipe }\end{array}$ & Moçambique & $\begin{array}{l}\text { Guiné- } \\
\text { Bissau }\end{array}$ & Angola \\
\hline $\begin{array}{l}\text { Guerras de } \\
\text { independência }\end{array}$ & $\mathrm{N}$ & $\mathrm{N}$ & $\mathrm{S}$ & $\mathrm{S} *$ & $\mathrm{~S}$ \\
\hline
\end{tabular}

Fonte: Tabela elaborada pela autora. 


\section{VIA 10: Independência de Portugal}

Para Mosca (2001), a combinação de diversos fatores impulsionou a independência dos territórios ultramarinos portugueses. Entre eles, pode-se citar: a) as vitórias militares dos movimentos de libertação, que se baseavam em um sistema de guerrilhas, causando a "saturação moral" do exército português; b) as crises dos pilares do sistema colonial, c) os desdobramentos políticos em Portugal que resultaram na Revolução de 25 de abril e d) as pressões internacionais em prol da descolonização.

O movimento militar de 25 de Abril de 1974 foi organizado por capitães que tinham lutado na África e que queriam tanto o fim do conflito no além-mar, quanto o rompimento da ditadura portuguesa que perdurava há 48 anos. Com forte apoio popular, o golpe destituiu o regime do Estado Novo, fazendo renascer uma nova era para Portugal. Dessa forma, em pouco tempo o novo governo acatou o princípio da autodeterminação dos povos e negociou com os movimentos de libertação as suas independências. Nesse ínterim, os novos dirigentes tinham como objetivo não somente encerrar os conflitos externos, mas também começar internamente um processo de democratização, tendo em vista que "toda a sociedade metropolitana estava exausta da guerra e dos transtornos que ela causava, mas, acima de tudo, estava sequiosa de uma liberdade que não conhecia havia décadas" (FRAGA, 2014, p. 91). Em suma, a Revolução dos Cravos resumia-se em única palavra: liberdade, que à sua maneira, passaria a ser vivida no continente e no além-mar.

$\mathrm{Na}$ tabela abaixo, é possível observar de maneira comparada os Acordos realizados e o reconhecimento das independências dos PALOP, a saber: 
Tabela 31 - Independência dos PALOP

\begin{tabular}{|l|l|l|l|l|l|}
\hline & $\begin{array}{l}\text { Movimento de } \\
\text { Libertação }^{48}\end{array}$ & $\begin{array}{c}\text { Local do } \\
\text { Acordo }\end{array}$ & $\begin{array}{c}\text { Data do } \\
\text { Acordo }\end{array}$ & $\begin{array}{c}\text { Data da } \\
\text { Independência }\end{array}$ & $\begin{array}{c}\text { Data do } \\
\text { Reconhecimento de } \\
\text { Portugal }\end{array}$ \\
\hline Cabo Verde & PAIGC & Lisboa & $19-12-1974$ & $05-07-1975$ & $05-07-1975$ \\
\hline $\begin{array}{l}\text { São Tomé e } \\
\text { Príncipe }\end{array}$ & MLSTP & Argel & $26-09-1974$ & $12-07-1975$ & $12-07-1975$ \\
\hline $\begin{array}{l}\text { Guiné- } \\
\text { Bissau }\end{array}$ & PAIGC & Argel & $26-08-1974$ & 1973 & $10-09-1974$ \\
\hline Moçambique & FRELIMO & Lusaka & $07-09-1974$ & $25-06-1975$ & $25-06-1975$ \\
\hline Angola & $\begin{array}{l}\text { MPLA, } \\
\text { FNLA } \\
\text { UNITA }\end{array}$ & Alvor & $15-01-1975$ & $11-11-1975$ & $21-02-1976$ \\
\hline
\end{tabular}

Fonte: Tabela elaborada pela autora, que insere novas informações à tabela exposta por Afonso (2009).

No contexto do fim da Guerra Colonial, destaca-se a volta dos portugueses e seus descendentes a Portugal, que somaram um contingente de aproximadamente 500.000 pessoas. Esses indivíduos passaram a ser chamados de "retornados" e sofreram muitas hostilidades advindas da sociedade portuguesa (TVBRASIL, 2015). Conforme observado, a variável referente à independência dos PALOP apresenta o mesmo valor para todos os cinco países, tendo em vista que eles realizaram a sua independência em contextos semelhantes e em um espaço de tempo muito próximo, conforme se observa na tabela a seguir:

Tabela 32 - Análise da independência dos PALOP

\begin{tabular}{|l|l|l|l|l|l|}
\hline Variável/ País & $\begin{array}{l}\text { Cabo } \\
\text { Verde }\end{array}$ & $\begin{array}{l}\text { São Tomé e } \\
\text { Príncipe }\end{array}$ & Moçambique & $\begin{array}{l}\text { Guiné- } \\
\text { Bissau }\end{array}$ & Angola \\
\hline $\begin{array}{l}\text { Independência de } \\
\text { Portugal }\end{array}$ & $\mathrm{S}$ & $\mathrm{S}$ & $\mathrm{S}$ & $\mathrm{S}$ & $\mathrm{S}$ \\
\hline
\end{tabular}

Fonte: Tabela elaborada pela autora.

\footnotetext{
${ }^{48}$ As siglas dos partidos políticos mencionados na tabela possuem a seguinte designação: PAICV: Partido Africano da Independência de Cabo Verde; MLSTP: Movimento para a Libertação de São Tomé e Príncipe; PAIGC: Partido Africano para a Independência da Guiné e Cabo Verde; FRELIMO: Frente de Libertação de Moçambique; MPLA: Movimento Popular de Libertação de Angola; FNLA: Frente Nacional de Libertação de Angola e UNITA: União Nacional para a Independência Total de Angola.
} 
O presente capítulo permitiu compreender os desdobramentos sociais, políticos e econômicos do colonialismo português na trajetória dos PALOP, evidenciando tanto as semelhanças quanto as diferenças presentes em cada cenário. No próximo Capítulo, serão analisadas as variáveis independentes antecedentes relacionadas aos 15 anos do regime de partido único que se instaurou em toda a África lusófona, sendo esse novo período profundamente conectado com os desdobramentos das independências e dos seus movimentos de libertação. 


\section{CAPÍTULO 4 - ESTUDO DE CASO 2: O REGIME DE PARTIDO ÚNICO NOS PALOP}

O presente capítulo tem como objetivo realizar um estudo de caso sobre o regime de partido único nos PALOP, analisando comparativamente as variáveis referentes a esse período histórico de acordo com a cadeia causal exposta no Capítulo 2. Dessa forma, será possível compreender as dinâmicas sociais, políticas e econômicas da África lusófona dos anos de 1975 a 1990. Na estrutura deste estudo, seis variáveis independentes antecedentes serão abordadas, sendo o primeiro tópico pautado na instauração de repúblicas populares de influência soviética e o último, nas guerras civis que ocorreram nos PALOP continentais.

Instauração de regimes de partido único no pós-independência de Portugal $(1973 / 1975-1990)$

\section{VIA 11: Repúblicas Populares de influência soviética}

O Capítulo 3 demonstrou que os movimentos que lutaram pela libertação dos PALOP tinham uma forte conexão com a ideologia marxista, tendo recebido durante os anos de guerra colonial apoio direto da URSS. Após a independência, esses movimentos, foram organizados sob a égide de partidos políticos e passaram a governar os Estados recém-criados. Desse modo, em toda a África lusófona, instauraram-se repúblicas com forte influência soviética, que resultaram em um regime de partido único que perdurou até a década de 1990. Para Moita (1979), as guerras de independência foram fundamentais para explicar as novas realidades dos PALOP pós-1975, visto que:

O desencadear de uma guerra popular prolongada supõe a intensa e extensa mobilização política das massas camponesas, tanto mais importante quanto, a partir de determinado momento, o movimento de libertação passa a controlar importantes áreas do território onde é possível estabelecer um novo tipo de vida social, transformando as relações de produção e inaugurando formas de poder popular. [...] $\mathrm{O}$ conjunto destes fatores proporcionam uma grande radicalização às lutas de libertação das colônias portuguesas. [...] A libertação nacional prolonga-se em revolução social (MOITA, 1979, p. 07). 
Moita (1979) acredita que o processo político que sucedeu a independência dos PALOP não foi linear, sendo muitas vezes repleto de contradições. Nesse contexto, a nova realidade política que se desdobrava nesses países, tais como Cabo Verde e GuinéBissau, passou a ser pautada na elaboração de uma "democracia revolucionária" (KOUDAWO, 2001). Bonet (2010), em uma entrevista realizada com Boaventura de Sousa Santos, afirma que, no século XX, o referido conceito relacionava-se à concepção leninista de "ditadura do proletariado", permeada por um forte componente autoritário. Jafar (2014) afirma que, no caso moçambicano, a escolha pelo socialismo se pautou nas seguintes premissas:

O governo de Moçambique dirigido pela Frelimo, teve três razões que justificam a adoção do sistema socialista e cooperou com a URSS porque: primeiro, acreditava-se que o Socialismo era caminho fácil de vencer o subdesenvolvimento. Segundo, alimentou-se a crença de que a ajuda soviética para países em vias do desenvolvimento tinha objetivo de criar e consolidar o poder político e promover a independência económica; e terceiro a URSS era contra o colonialismo, o racismo, o zionismo e outras formas de exploração e descriminação (JAFAR, 2014, p. 14).

De acordo com Chabal (2002), o socialismo se constituiu como a ideologia que permeou a fundação dos estados-nação de todos os PALOP. Contudo, ele destaca que a instauração de sistemas unipartidários emergiu não somente nos contextos desses países, mas estiveram presentes em grande parte do continente africano na década de 1980, conforme se observa a seguir:

If the PALOP regimes were singular in their choice of socialism as the founding ideology of the new nation-state, they quickly evolved a pattern of politics familiar in Africa. Admittedly, their political creed presupposed the dominance of the ruling party so that, unlike their French or English speaking counterparts, they need not need to justify the establishment of one-party states. Nevertheless, after a few years, there was little to distinguish these regimes politically from their counterparts in the rest of the continent. Indeed, by the first half of the eighties, there were in Africa only a few (nominally) multiparty democratic states. As one-party states, the PALOP were thus no different from the bulk of other African countries (CHABAL, 2002, p. 88).

Nesse ínterim, Mosca (2001) ressalta que a importância da relação que existia entre os militares e as elites políticas que adotaram a ideologia marxista no universo dos PALOP no pós-independência, conforme se observa no excerto abaixo:

As alianças entre as alas políticas com dominância das ideologias de esquerda e os militares que ocupavam posições hierárquicas de relevo como 
consequência das prestações na guerra formavam cúpulas onde se combinavam o esquerdismo e o populismo, resultando discursos e posicionamentos típicos destas configurações (MOSCA, 2001, p. 68).

Dessa forma, é possível construir a seguinte tabela analítica em relação a essa variável:

Tabela 33 - Análise da presença de repúblicas populares de influência soviética nos PALOP

\begin{tabular}{|l|l|l|l|l|l|}
\hline Variável/ País & $\begin{array}{l}\text { Cabo } \\
\text { Verde }\end{array}$ & $\begin{array}{l}\text { São Tomé e } \\
\text { Príncipe }\end{array}$ & Moçambique & $\begin{array}{l}\text { Guiné- } \\
\text { Bissau }\end{array}$ & Angola \\
\hline $\begin{array}{l}\text { Repúblicas de } \\
\text { populares de } \\
\text { influência soviética }\end{array}$ & $\mathrm{S}$ & $\mathrm{S}$ & $\mathrm{S}$ & $\mathrm{S}$ & $\mathrm{S}$ \\
\hline
\end{tabular}

Fonte: Tabela elaborada pela autora.

\section{VIA 12: Direitos políticos e liberdades civis durante o regime de partido único}

Em muitos países africanos, algumas experiências democráticas ocorreram logo após a independência, conforme se observou em Botsuana e Maurícia. Contudo, tal cenário não ocorreu nas ex-colônias lusófonas na África, que logo após a independência tiveram a instauração de regimes de partido único de caráter socialista (CHABAL, 1996). Esses Estados independentes que surgiram a partir dos antigos territórios ultramarinos portugueses na África tiveram, desde a sua origem, um componente militar que se expressou de maneira idiossincrática em cada PALOP, em um cenário composto pelas seguintes características:

1) Pela presença dos militares na burocracia (devido ao protagonismo destes elementos durante as lutas de libertação), que eram caracterizados por possuírem uma forte carga ideológica, limitada preparação técnica e estavam, na maioria dos casos, fortemente relacionados com as hierarquias do poder "tradicional";

2) Pelo peso e hierarquia das instituições de soberania e de defesa e segurança na organização dos Estados, secundarizando a economia, com o slogan da "política no posto de comando";

3) Pela subordinação do Estado aos órgãos máximos dos partidos únicos e pelo controle destes por um número reduzido de dirigentes, considerando ainda as irregulares aplicações do princípio da organização leninista que "o partido dirige o Estado e a sociedade";

4) Pela organização dos Estados inspirada nos métodos de trabalho e nas linhas de comando militares (MOSCA, 2001, p. 68). 
De acordo com o Índice de Democracia Eleitoral (V-DEM, 2016) apresentado no tópico sobre direitos políticos e liberdades civis do capítulo anterior, observa-se um pequeno aumento dos direitos políticos nos PALOP durante o pós-independência. Isso significa que o cenário de incertezas e conflitos que se desdobrou nesse momento (principalmente nos PALOP continentais) resultou em ganhos democráticos mínimos no escopo eleitoral desses Estados. Essas mudanças foram evidenciadas, em grande parte, pela existência de eleições legislativas periódicas, nas quais era possível aprovar ou rejeitar a constituição geral do parlamento, sendo proibido o voto nominal. Nesse ínterim, podia-se somente votar "sim" ou "não" para a composição da Assembleia Nacional, que posteriormente escolhia o presidente do país. Nesses moldes, o presidente tinha um mandato de cinco anos, podendo ser reeleito de maneira irrestrita.

No Anexo E é possível observar a trajetória eleitoral de todos os PALOP desde as suas primeiras eleições. Em Cabo Verde, a primeira eleição legislativa ocorreu em 1975, resultando em 95,58\% de aprovação para a Assembleia Constituinte. A segunda eleição ocorreu em 1980, com 92,6\% de aprovação; sendo que o último pleito do sistema monopartidário ocorreu em 1985, com 94,87\% de votos favoráveis. Destaca-se que, de 1975 a 1990, o presidente eleito pelo órgão legislativo foi o mesmo: Aristides Pereira. Da mesma forma, em São Tomé e Príncipe as primeiras eleições legislativas ocorreram em 1975, 1980 e 1985, sendo Manuel Pinto da Costa eleito presidente durante esses 15 anos (AFRICAN ELECTIONS, 2016). Em síntese tem-se que durante o período de partido único a estrutura de direitos políticos dos PALOP insulares foi edificada sob pilares autocráticos, expressos pela inexistência de eleições presidenciais ou nominais para o parlamento, pela falta de alternância de poder, pela existência e domínio de um único partido político, pela perseguição dos dissidentes, entre diversos outros aspectos ditatoriais.

Nesse contexto, é importante mencionar que nenhum desses países sofreu qualquer golpe de Estado ou conflito armado nos seus territórios, fator que ajuda a explicar o cenário de estabilidade política, econômica e social que eles vivenciaram no momento das suas transições para a democracia. No caso são tomense, ressalta-se que em 1990 ocorreu um referendo constitucional em prol de transformações democráticas, obtendo a aprovação de $95,3 \%$ da população. Esse referendo se inseriu no espectro das primeiras ações realizadas no âmbito da mudança de regime no final de 1980, revelando 
a abertura e a vontade política das suas elites em iniciar a democratização com o apoio e legitimidade popular.

Em Angola, durante todo o regime unipartidário o país se encontrava em guerra civil, inserido em uma profunda instabilidade social, política e econômica. Ao contrário do que ocorrera nos PALOP insulares, o país não possuía condições para construir bases políticas fortes que pudessem levar a um processo exitoso da sua democracia em um curto período de tempo. Como exemplo, tem-se que entre 1975 e 1990, somente duas eleições legislativas foram realizadas, nos anos de 1980 e 1986 (AFRICAN ELECTIONS, 2016). Durante o período monopartidário, o MPLA governava o país sob a liderança de Agostinho Neto. De acordo com Pacheco (2014),

\begin{abstract}
Não é verdade que o Estado socialista proclamado por Agostinho Neto, em outubro de 1976, fosse um Estado marxista-leninista organicamente articulado e com uma economia sólida e planificada que espelhasse os interesses da maioria. Pelo contrário, era um Estado mimético que aplicava confusamente as fórmulas soviéticas de direção. Baseado em um modelo autoritário e ditatorial de governação social, apelava incessantemente ao culto da personalidade e inspirava-se nos preceitos de um nacionalismo de tipo reacionário e excludente que perdura até aos nossos dias. Essa governação que veio até 1992, com alguns traços na atualidade, caracterizou-se por um sistema de partido único fortemente militarizado; por um Poder sobreposto aos interesses coletivos; por uma distorção política dos fatos [..] e por uma vigilância cerrada sobre o povo imbecilizado (PACHECO, 2014, p. 180).
\end{abstract}

No caso angolano, destaca-se que de 1977 a 1979 a repressão resultou em milhares de vítimas. Aproximadamente um ano depois da independência ter sido reconhecida por Portugal, as autoridades do país alegaram a existência de uma tentativa de golpe de Estado contra Agostinho Neto no dia 27 de maio de 1977. O estopim desse evento ocorreu com as manifestações que ocorreram em Luanda a favor de Nito Alves, então Ministro da Administração Interna e membro do Comité Central do MPLA, que defendia uma ideologia pautada na ortodoxia soviética. Esse posicionamento era distinto do apoiado pelo presidente, que adotava uma perspectiva "terceiro mundista". Como resposta, Neto afirmou que "não haverá perdão para quem pense de forma diferente da linha oficial do MPLA" (GOUVEIA; KRIEGER, 2011, s/p), e os dissidentes dentro do partido começaram a ser designados "fraccionistas". Nesse ínterim, iniciou-se uma forte perseguição, sendo esses ataques descritos da seguinte maneira:

Há relatos de famílias chacinadas, presos enterrados vivos, corpos lançados de aviões ou ravinas, fuzilamentos arbitrários, tortura aplicada com uma 
crueldade indescritível. As cadeias eram sucessivamente cheias e esvaziadas. Estudantes que estavam na União Soviética, na Bulgária, na Tchecoslováquia e noutros países do Leste foram mandados regressar e muitos foram decapitados sem se conhecer a razão. Nas faculdades, desapareceram cursos inteiros. Desapareceram também novos e velhos militantes do MPLA, ministros e chefes militares (GOUVEIA; KRIEGER, 2011, s.p.).

De acordo com o Golveia e Krieger (2016), o número de mortos nesses incidentes ainda é incerto, sendo totalizado em 80 mil pessoas pela Fundação 27 de Maio, 60 mil pela Folha 8, 40 mil pela Anistia Internacional e 15 mil pela Direção de Informação e Segurança de Angola (DISA). O assassinato de Sitta Valles, que será abordado no excerto a seguir, foi considerado um dos mais emblemáticos desse período, a saber:

Sitta Vales foi fuzilada às 5 da manhã de 1 de agosto de 1977. Um tiro em cada perna, um tiro em cada braço, o corpo caiu na vala previamente aberta antes de ser dado o tiro de misericórdia. O corpo, ou o que dele restava: Sita Valles havia sido torturada e violada múltiplas vezes pelos homens da DISA. Rebelde até ao último minuto, recusou a venda e obrigou os homens do pelotão de fuzilamento a enfrentarem o seu olhar. A portuguesa, nascida em Cabinda, tinha então 26 anos e trocara uma vida confortável em Portugal e um curso de medicina para regressar a Angola, país que considerava ser o seu para defender a ortodoxia soviética em supostos tempos de democracia (GOUVEIA; KRIEGER, 2011, s.p.).

É interessante notar que o ano de 1977 resultou em um momento de significativa repressão também em Cabo Verde, que no regime de partido único era regido por leis que intimidavam os cidadãos, permitindo uma ação sem controle dos serviços policiais. Nesse período, ocorreram as prisões de muitas pessoas conhecidas no país, a saber: Lulu Marques, Toi de Forro, Titino Boxer, Zeca Matos, Ti Nenê, Manuel Chantre, Mário Leite, Adelino Leite, entre outros (CARDOSO, 2016). Cardoso (2016) conecta esses acontecimentos aos desencadeados em Angola, descrevendo esse cenário da seguinte maneira:

Os acontecimentos de 1977, desencadeados com a inverossímil justificação de prevenção de atos terroristas, teve como objetivo principal a intimidação de uma comunidade, que teve um papel decisivo no processo de independência e que é conhecida pela sua autonomia de opiniões e capacidade de influência no país. O "timing" escolhido para as prisões foi perfeito. Angola acabava de ser sacudida, violentamente, pela tentativa de golpe de Estado de 27 de Maio, liderado por Nito Alves (CARDOSO, 2016, p. 73).

Apesar do ambiente de repressão vivenciado na arena cabo-verdiana, ao comparar os casos da Guiné-Bissau e de Cabo Verde, que até 1980 eram governados por 
um mesmo partido, o PAIGC, Koudawo (2001) destaca importantes diferenças na governação, ressaltando que a repressão foi menor no arquipélago quando comparada à guineense, a saber:

\begin{abstract}
Na Guiné-Bissau, pelo contrário, o impacto da mobilização e do monolitismo foi mais forte. Não só o PAIGC não conheceu fenômenos de dissidência fecunda, como as opiniões divergentes foram combatidas e amordaçadas. Contrariamente a Cabo Verde, que não figurava na lista negra dos relatórios internacionais sobre direitos humanos, a Guiné-Bissau tem um denso passado de mau desempenho no respeito da liberdade de expressão. Enquanto que em Cabo Verde houve poucos assassinatos políticos [...], na Guiné-Bissau os fenômenos de divergência política muitas vezes deram lugar a prisões, desaparições e execuções (KOUDAWO, 2001, p. 164).
\end{abstract}

Apesar dessas diferenças, Cardoso (2016) aponta que, em ambos os países, o PAIGC/PAICV agia de modo a suprimir as ações autônomas da sociedade civil, instaurando um modelo autocrático e dominador, que tinha como objetivo o controle absoluto de toda a sociedade, exprimindo características demagógicas reminiscentes do fascismo. Nesse contexto, o autor ressalta que um dos objetivos do partido era a criação de um "homem novo", que deveria ser completamente alinhado às diretrizes ideológicas da instituição. $\mathrm{O}$ excerto a seguir revela o cenário de grande supressão social vivenciado por Cabo Verde durante o regime monopartidário, ressaltando-se o fato de que as elites políticas do país nesse momento se encontravam imersas primordialmente no escopo de atuação do PAIGC/PAICV, conforme se observa a seguir:

\begin{abstract}
A supressão da sociedade civil cabo-verdiana tentada pelo poder colonial foi, deste modo, conseguida pelo regime do PAIGC/PAICV nos quinze anos que dirigiu o país. Supressão porque a sociedade, desprovida da sua dinâmica natural, viu-se sem a possibilidade de criar as elites que as liderassem nos domínios cultural, econômico e político, e completamente subjugada pela lógica totalitária, nem o alcance e o nível de escolaridade atingido conseguiu contrariar a deriva da sociedade, aos sabores da influência da subcultura político-ideológica importada (CARDOSO, 2016, p. 190).
\end{abstract}

Em Moçambique, durante o período de partido único, ocorreram eleições legislativas somente em 1977 e 1986. Por se encontrar em situação de guerra civil semelhante à de Angola, o contexto político do país apresentou traços de grande instabilidade, com uma reduzida cultura eleitoral. No âmbito das liberdades civis, Paredes (2014) afirma que "as práticas repressoras e a ação policialesca de funcionários estatais no sentido de controlar a sociedade moçambicana será um dos elementos contribuintes 
para resistências e para a negatividade da memória vinculada aos "tempos de Samora"” (PAREDES, 2014, p. 153). As práticas autocráticas advindas dos agentes do Estado nesse período histórico se focalizavam em suprimir protestos e manifestações que questionassem o projeto político da FRELIMO, em um cenário no qual se observou a "continuidade do aparato repressivo entre o Estado Colonial e o Estado Socialista PósIndependência" (PAREDES, 2014, p. 154).

Já a Guiné-Bissau realizou quatro eleições legislativas no momento unipartidário, sendo elas nos anos de 1972, 1976, 1984 e 1989 (AFRICAN ELECTIONS, 2016). Entretanto, esse período foi marcado por grande instabilidade social, política e econômica. Essa instabilidade se explica porque, no contexto guineense, as mesmas pessoas que lutaram pela libertação do domínio português assumiram o comando do país no pós-independência. Nesse período, as principais personalidades que combateram lado a lado durante os 11 anos de guerra colonial impetraram uns contra os outros inúmeros golpes e contragolpes de Estado. O primeiro presidente guineense foi Luís Cabral, irmão de Amílcar Cabral. A sua administração foi marcada por uma expressiva desarmonia social e política, que se encontrou pautada em duas questões principais, a saber: "as longas lutas fratricidas entre a ala militar e a direção política do PAIGC e as contradições entre guineenses e cabo-verdianos em relação ao projeto de Estado binacional imposto pelo PAIGC, sem o consentimento dos dois povos" (LOPES, 2010, p. 08). O governo de Cabral também foi caracterizado por impor um cenário de repressão e perseguições, causando insatisfação em diversos segmentos sociais, conforme se observa no excerto a seguir:

\begin{abstract}
Em seis anos de independência total da nossa terra, 500 pessoas foram fuziladas sumariamente, sem julgamento, e enterradas em valas comuns nas matas de Cumeré, Portogole e de Mansoa. Publicamos hoje, os nomes de algumas pessoas que foram massacradas pelo regime de Luís Cabral, pois só as fichas criminais é que chegaram ao conhecimento do Conselho da Revolução [...] O regime de Luís Cabral violou flagrantemente as normas dos direitos do homem e nenhum comando africano, nenhum dissidente foi levado ao tribunal. Foram executados barbaramente no meio das florestas, contra os mais elementares princípios de justiça e contra os princípios do nosso glorioso partido (GOLVEIA, 2010, p. 13).
\end{abstract}

Nessa conturbada realidade, em 1978 Cabral convidou o Comandante e exguerrilheiro João Bernardo (Nino) Vieira para ser o seu primeiro-ministro. Contudo, dois anos depois, Nino Vieira liderou o "Movimento Reajustador 14 de Novembro de 1980", 
que impetrou um golpe Estado resultando na primeira grande intervenção dos militares na cena política guineense. Além da ascensão Vieira à presidência, esse fenômeno teve como consequências o rompimento do caráter binacional do PAIGC com Cabo Verde e, internamente, agravou muitos dos conflitos políticos já existentes, a saber:

\begin{abstract}
Com a chegada do Nino Vieira à chefia do Estado, os conflitos internos no seio do PAIGC tomaram outros contornos, o que levou à desestabilização da governação, às constantes intentonas de golpes de Estado, às depurações no seio do partido e do aparelho do Estado, às demissões dos seus maiores apoiantes no golpe de Estado de 1980, detenção e fuzilamentos de altas figuras do Estado, todos militares e também a crítica situação econômico-financeira do país (LOPES, 2010, p. 03).
\end{abstract}

Em síntese, tem-se que a análise realizada permitiu compreender que os anos que se seguiram à independência dos PALOP trouxeram a liberdade de séculos do domínio português, mas não asseguraram direitos políticos e liberdades civis às suas populações. Principalmente nos PALOP continentais, a repressão era intensa com os dissidentes, ocasionando em episódios extremamente violentos, tais como os observados em Angola entre 1977 e 1979. Nesse contexto, tem-se que, de 1975 a 1990, o resultado negativo no escopo da variável "direitos políticos e liberdades civis" se aplica a todos os PALOP, conforme se observa na tabela abaixo. Destaca-se que esses resultados podem ser comprovados por meio dos Índice de Democracia Eleitoral (V-DEM) e do Índice de Componentes Liberais (V-DEM), expostos no Capítulo anterior no tópico sobre direitos políticos e liberdades civis (página 126 da presente tese).

Tabela 34 - Análise dos direitos políticos e liberdades civis dos PALOP durante o regime de partido único

\begin{tabular}{|l|l|l|l|l|l|}
\hline Variável/ País & $\begin{array}{l}\text { Cabo } \\
\text { Verde }\end{array}$ & $\begin{array}{l}\text { São Tomé e } \\
\text { Príncipe }\end{array}$ & Moçambique & $\begin{array}{l}\text { Guiné- } \\
\text { Bissau }\end{array}$ & Angola \\
\hline $\begin{array}{l}\text { Direitos políticos e } \\
\text { liberdades civis (t2) }\end{array}$ & $\mathrm{N}$ & $\mathrm{N}$ & $\mathrm{N}$ & $\mathrm{N}$ & $\mathrm{N}$ \\
\hline
\end{tabular}

Fonte: Tabela elaborada pela autora. 


\section{VIA 13: Crescimento econômico dos PALOP durante o regime de partido único}

O pós-independência representou um momento de grande entusiasmo para as populações das ex-colônias portuguesas na África. Contudo, notadamente no âmbito econômico, muitas das expectativas positivas de transformação da economia não foram concretizadas. Como explicação para o impedimento do crescimento econômico dos PALOP durante o período do regime de partido único, Mosca (2001) destaca os seguintes aspectos:

a) Centralização da economia, com grande intervenção estatal;

b) Inexistência de mecanismos que assegurassem a acumulação privada;

c) Nacionalização dos meios de produção;

d) Combate político da figura do empresário, que passou a ser denegrido socialmente;

e) Alterações significativas com parceiros externos, com obstáculos na relação econômica com Portugal;

f) Retirada massiva e repentina de empresários e burocratas estrangeiros e, finalmente,

g) "Conflitos internos de diversa intensidade, provocando situações de instabilidade política, econômica e social variáveis” (MOSCA, 2001, p 71).

Nesse contexto, tem-se que no período do partido único o crescimento econômico dos PALOP insulares se apresentou um pouco superior ao dos PALOP continentais, fator que se explica devido a questões presentes na sua configuração histórica, tais como a inexistência de conflitos armados nos seus territórios durante o pósindependência. Contudo, Cabo Verde e São Tomé e Príncipe enfrentaram importantes desafios econômicos como países independentes em função da sua insularidade combinada com uma diminuta população. Além dos aspectos limitantes que eles vivenciavam desde o período colonial, conforme exposto no tópico sobre crescimento econômico do capítulo anterior, os novos governantes dos arquipélagos tiveram que lidar com os seguintes problemas, conforme afirma Espírito Santo (2013a).

a) Reduzido valor do PIB;

b) Reduzida arrecadação de impostos (devido à sua pequena população); 
c) Dificuldade em construção de infraestrutura e serviços básicos, pois eles consomem grande parte das pequenas receitas do Estado;

d) Tendência à grande importação de produtos manufaturados;

e) Dificuldade em aumentar a diversidade das suas exportações;

f) Grande especialização da mão-de-obra em determinados setores (notadamente o setor primário) e

g) Grande vulnerabilidade em relação aos mercados internacionais.

Apesar das dificuldades perpassadas por esses Estados insulares, eles chegaram ao ano de 1990 com os maiores valores de PIB per capita dos PALOP. Como exemplo, observa-se que de 1975 a 1990, o aumento desse indicador em Cabo Verde foi maior do que $100 \%$. Nesse mesmo período, verificou-se uma expressiva redução dos valores angolanos, que apresentou resultados próximos ao guineense em 1990. Nesse contexto é possível verificar alguns dos reflexos econômicos negativos advindos das guerras civis em Angola e Moçambique, conforme se observa na tabela a seguir:

Tabela 35 - PIB per capita dos PALOP entre 1975 e 1990 (V-DEM, 2016)

\begin{tabular}{|l|l|l|l|l|}
\hline & $\mathbf{1 9 7 5}$ & $\mathbf{1 9 8 0}$ & $\mathbf{1 9 8 5}$ & $\mathbf{1 9 9 0}$ \\
\hline Cabo Verde & 524,74 & 840,54 & $1.081,39$ & $1.233,45$ \\
\hline $\begin{array}{l}\text { São Tomé e } \\
\text { Príncipe }\end{array}$ & $1.421,45$ & $2.009,12$ & $1.487,47$ & $1.390,74$ \\
\hline Moçambique & $1.403,62$ & $1.220,47$ & 920,35 & $1.113,56$ \\
\hline Guiné-Bissau & 925,07 & 754,33 & 849,91 & 797,20 \\
\hline Angola & $1.072,81$ & 961,43 & 779,33 & 868,07 \\
\hline
\end{tabular}

Fonte: Tabela elaborada pela autora com dados do V-DEM (2016).

Outro indicador que pode ser utilizado para compreender a evolução econômica dos PALOP desde o período do regime de partido único consiste nos seus níveis de inflação. De acordo com Balbinotto Neto (2016), a inflação exerce um impacto no crescimento econômico por três motivos principais:

i) a inflação afeta tanto a oferta como a demanda agregada, tornando mais difícil para as famílias e firmas tomar as decisões corretas em resposta aos sinais de mercado. Quando todos os preços estão crescendo, os agentes econômicos podem achar difícil distinguir entre mudanças nos preços relativos 
e mudanças no nível geral de preços. Esta dificuldade pode interferir com a operação eficiente do sistema de preços e, portanto, reduzir o crescimento econômico;

ii) a inflação pode impor vários custos para a economia, tais como os custos de menu, referentes as mudanças de preços e salários frequentemente e

iii) a inflação pode afetar as taxas de poupança e investimento, reduzindo a proporção do PIB devotada ao investimento, e provocando que a economia acumule menos capital físico e humano.

Nesse ínterim, observou-se que a inflação de Guiné-Bissau chegou ao patamar de $64,8 \%$ em 1980, momento no qual foi realizado o golpe militar no país (marcando também o rompimento do PAIGC em Cabo Verde, que passou a se chamar PAICV). Destaca-se também que, em 1985, o valor do referido índice chegou a 112,7\% no país. Apesar de Angola ter tido um breve período de baixa inflação entre 1985 e 1990, o seu ápice inflacionário ocorreu na década de 1990, chegando a uma taxa de $4.150 \%$ no ano de 1996 (FMI, 2016). Devido em grande parte às guerras civis, o crescimento econômico de Angola e Moçambique se mostrou abalado. Para ilustrar essa situação no âmbito dos conflitos domésticos, Jafar (2014) descreve e economia moçambicana do período da seguinte maneira:

[...] a produção agrícola-industrial baixou 50\%; a inflação aumentou. O PIB caiu num profundo precipício, muitas infraestruturas económicas e sociais ficaram destruídas (campos agrícolas, indústria, estradas, pontes, linhasférreas, rede de telecomunicações, escolas, hospitais, lojas rurais etc.); abandono e/ou destruição das redes escolar e sanitária; a ligação campo-cidade tornou-se impossível, a deslocação de pessoas e bens parou profundamente. Acelerou-se o êxodo rural, o que agudizou a pobreza urbana nas cidades, a taxa de desemprego disparou; milhões de deslocados, milhões de refugiados nos países vizinhos; milhares de crianças órfãs, mais de um milhão de mortes. As exportações e importações diminuíram drasticamente e outros indicadores macroeconômicos se revelaram desfavoráveis para a vida económica nacional [...] A dívida externa aumentou quase $500 \%$ e mais de $60 \%$ do Investimento Direto Estrangeiro foi cancelado ou nem sequer iniciados. $\mathrm{O}$ efetivo de gado bovino, cerca de um milhão e trezentas mil cabeças em 1980, ficou reduzido a cerca de 250000 cabeças, em 1992, em grande parte devido à guerra. Os indicadores da área da saúde, na sequência da destruição de centros de saúde e assassínio de técnicos, sofreram um retrocesso de décadas (JAFAR, 2014, p. 16).

Apesar de todos os PALOP analisados possuírem um baixo crescimento econômico durante os seus regimes de partido único, os PALOP insulares apresentam resultados relativamente superiores quando comparados aos seus pares continentais, permitindo construir a seguinte tabela: 
Tabela 36 - Análise do crescimento econômico dos PALOP durante o regime de partido único

\begin{tabular}{|l|l|l|l|l|l|}
\hline Variável/ País & $\begin{array}{l}\text { Cabo } \\
\text { Verde }\end{array}$ & $\begin{array}{l}\text { São Tomé e } \\
\text { Príncipe }\end{array}$ & Moçambique & $\begin{array}{l}\text { Guiné- } \\
\text { Bissau }\end{array}$ & Angola \\
\hline $\begin{array}{l}\text { Direitos políticos e } \\
\text { liberdades civis (t2) }\end{array}$ & $\mathrm{S}$ & $\mathrm{S}$ & $\mathrm{N}$ & $\mathrm{N}$ & $\mathrm{N}$ \\
\hline
\end{tabular}

Fonte: Tabela elaborada pela autora.

\section{VIA 14: Desenvolvimento social dos PALOP durante o regime de partido único}

As guerras civis que se desdobraram nos PALOP continentais no período do pósindependência fomentaram um cenário de grande instabilidade social, política e econômica. Em países como Moçambique, a devastação foi intensa, fazendo com que a pobreza se instaurasse de maneira estrutural na sua sociedade. A análise da expectativa de vida dos PALOP de 1975 a 1990 revela os efeitos da guerra civil em países como Angola e Moçambique, que em 15 anos aumentaram somente dois anos do referido índice, ao passo que em Cabo Verde esse aumento foi de quase 10 anos. Em São Tomé e Príncipe, a expectativa de vida aumentou em somente três anos, mas é importante destacar que os seus valores são muito maiores do que os dos PALOP continentais, apresentando uma diferença de 20 anos quando comparado a Angola, conforme se identifica na tabela abaixo $^{49}$ :

Tabela 37 - Expectativa de vida dos PALOP entre 1975 e 1990 (V-DEM, 2016)

\begin{tabular}{|l|l|l|l|l|l|l|}
\hline & $\mathbf{1 9 7 5}$ & $\mathbf{1 9 7 8}$ & $\mathbf{1 9 8 1}$ & $\mathbf{1 9 8 4}$ & $\mathbf{1 9 8 7}$ & $\mathbf{1 9 9 0}$ \\
\hline Cabo Verde & 56,98 & 58,83 & 61,04 & 63,12 & 64,86 & 66,08 \\
\hline $\begin{array}{l}\text { São Tomé e } \\
\text { Príncipe }\end{array}$ & 58,98 & 60,21 & 60,63 & 60,84 & 61,30 & 61,81 \\
\hline Moçambique & 41,56 & 42,55 & 42,95 & 42,95 & 43,06 & 43,64 \\
\hline Guiné-Bissau & 44,85 & 45,43 & 46,15 & 47,00 & 47,99 & 49,09 \\
\hline Angola & 39,00 & 39,84 & 40,31 & 40,67 & 40,99 & 41,15 \\
\hline
\end{tabular}

Fonte: Tabela elaborada pela autora com dados do V-DEM (2016).

\footnotetext{
${ }^{49}$ Para fins de comparação, a expectativa de vida em 1975 era de 60,84 anos no Brasil, 68,93 em Portugal, 72,68 nos EUA, 74,41 no Japão, 64,2 na Coreia do Sul e 54,54 na África do Sul. Já em 1990, os valores era de 66,47 para o Brasil, 74,25 para Portugal, 75,40 para os EUA, 79,04 para o Japão, 71,72 para a Coreia do Sul e 62,10 para a África do Sul (V-DEM, 2016).
} 
Da mesma forma que a expectativa de vida, entre os anos 1975 e 1990, a mortalidade de todos os PALOP declinou, com exceção de São Tomé e Príncipe, que apresentou um aumento de 1,15\% durante esses 15 anos. Por outro lado, Cabo Verde apresentou uma redução de 44\%, sendo a diminuição de Moçambique e de Guiné-Bissau de aproximadamente $10 \%$ e, finalmente, de $17 \%$ no caso de Angola. Em 1990, somente Cabo Verde apresentou valores de mortalidade infantil considerados médios, seguido por São Tomé e Príncipe, que ocupava a segunda posição no contexto dos PALOP. Nesse cenário, apesar dos valores são tomenses serem de aproximadamente a metade dos quantitativos de Moçambique, Guiné-Bissau e Angola, eles ainda eram classificados como altos (acima de 50 mortes) ${ }^{50}$, a saber:

Tabela 38 - Mortalidade infantil dos PALOP entre 1975 e 1990 (V-DEM, 2016)

\begin{tabular}{|l|l|l|l|l|l|l|}
\hline & $\mathbf{1 9 7 6}$ & $\mathbf{1 9 7 8}$ & $\mathbf{1 9 8 1}$ & $\mathbf{1 9 8 4}$ & $\mathbf{1 9 8 7}$ & $\mathbf{1 9 9 0}$ \\
\hline Cabo Verde & 83,30 & 74,80 & 65,00 & 57,60 & 52,00 & 47,30 \\
\hline $\begin{array}{l}\text { São Tomé e } \\
\text { Príncipe }\end{array}$ & 58,20 & 58,70 & 59,90 & 62,50 & 65,10 & 66,60 \\
\hline $\begin{array}{l}\text { Moçambique } \\
\text { Guiné-Bissau }\end{array}$ & 171,50 & 170,20 & 169,00 & 166,00 & 160,70 & 155,10 \\
\hline Angola & 152,16 & 142,88 & 132,60 & 129,90 & 128,00 & 126,10 \\
\hline
\end{tabular}

Fonte: Tabela elaborada pela autora com dados do V-DEM (2016).

No que tange aos anos de escolaridade das pessoas com mais de 15 anos de idade, tem-se que entre 1976 e 1990, os dados também apresentaram resultados mais positivos no âmbito dos PALOP insulares. Em 1975, o indicador encontra-se disponível somente para Angola e Moçambique, exprimindo que em ambos os casos a média de escolaridade dos cidadãos com mais de 15 anos era de menos de um ano. Esse fator explica o elevado número de analfabetos nesses países. Já no ano de 1981, há pela primeira vez dados disponíveis para todos os PALOP, estando São Tomé e Príncipe na liderança, com um total de 4,29 anos. Nesse período, o único país que apresenta uma

\footnotetext{
${ }^{50}$ Para fins de comparação, em 1990 a mortalidade infantil era de 51,6 no Brasil, 11,6 em Portugal, 46,9 na África do Sul, 4,6 para o Japão, 9,4 para os EUA e 6,1 para a Coreia do Sul.
} 
média inferior a um ano é a Guiné-Bissau. Já em 1990, apesar de ter tido uma pequena queda, São Tomé e Príncipe ainda continuam como o país no qual os seus cidadãos possuem maior escolaridade no âmbito dos PALOP. Enquanto a melhora cabo-verdiana foi relativamente grande, a dos outros países da África lusófona ocorreu de maneira mais reduzida ${ }^{51}$, a saber:

Tabela 39 - Quantidade de anos de escolaridade dos cidadãos com mais de 15 anos de idade nos PALOP entre 1975 e 1990 (V-DEM, 2016)

\begin{tabular}{|l|l|l|l|l|}
\hline & $\mathbf{1 9 7 5}$ & $\mathbf{1 9 8 1}$ & $\mathbf{1 9 8 5}$ & $\mathbf{1 9 9 0}$ \\
\hline Cabo Verde & - & 1,90 & 2,38 & 3,85 \\
\hline $\begin{array}{l}\text { São Tomé e } \\
\text { Príncipe }\end{array}$ & - & 4,29 & 5,22 & 4,75 \\
\hline Moçambique & 0,88 & 1,11 & 1,49 & 1,95 \\
\hline Guiné-Bissau & - & 0,74 & 1,17 & 1,53 \\
\hline Angola & 0,54 & 1,01 & 1,38 & 1,84 \\
\hline
\end{tabular}

Fonte: Tabela elaborada pela autora com dados do V-DEM (2016).

Considerando a análise realizada, tem-se que, mais uma vez, apesar do desenvolvimento social de todos PALOP se apresentar (relativamente) baixo, os dados relacionados aos PALOP insulares são significativamente melhores do que os dos continentais, conforme se observa na tabela a seguir.

\section{Tabela 40 - Análise do desenvolvimento social dos PALOP durante o regime de partido único}

\begin{tabular}{|l|l|l|l|l|l|}
\hline Variável/ País & $\begin{array}{l}\text { Cabo } \\
\text { Verde }\end{array}$ & $\begin{array}{l}\text { São Tomé e } \\
\text { Príncipe }\end{array}$ & Moçambique & $\begin{array}{l}\text { Guiné- } \\
\text { Bissau }\end{array}$ & Angola \\
\hline $\begin{array}{l}\text { Desenvolvimento } \\
\text { social (t2) }\end{array}$ & $\mathrm{S}$ & $\mathrm{S}$ & $\mathrm{N}$ & $\mathrm{N}$ & $\mathrm{N}$ \\
\hline
\end{tabular}

Fonte: Tabela elaborada pela autora.

51 Para fins de comparação, é importante destacar que em 1975, os valores referentes aos anos de escolaridade para os cidadãos com mais de 15 anos de idade no Brasil eram 3,89, para Portugal eram 4,53, para o Japão 10,31, para a Coreia do Sul, 6,67 e para os EUA, 11,20 e 4,95 para a África do Sul. Já em 1985, os valores eram 5,24 para o Brasil, 5,35 para Portugal, 11,01 para o Japão, 9,58 para a Coreia do Sul e 12,07 para os USA e 5,40 para a África do Sul. Em 1990, os valores eram 6,35 para o Brasil, 5,51 para Portugal, 11,35 para o Japão, 10,28 para a Coreia do Sul, 11,35 para os EUA e 5,68 para a África do Sul (V-DEM, 2016). 


\title{
VIA 15: Perfil das elites políticas dos PALOP
}

No momento da democratização, as elites políticas dos PALOP insulares apresentavam um perfil relativamente mais flexível do que as elites dos PALOP continentais. A existência tanto das guerras de independência quanto das guerras civis fez com que as elites dos PALOP continentais apresentassem características idiossincráticas, sendo mais inflexíveis e pendentes ao autoritarismo contra aqueles que se colocassem contra o seu governo. De acordo com José Vicente Lopes (2015), as elites cabo-verdianas estavam comprometidas com a transformação social do país desde a época da independência, visto que:

Uma vez proclamada a independência, os dirigentes cabo-verdianos do PAIGC ainda tiveram a lucidez suficiente para perceber onde estava a razão fundamental da nossa independência. E essa razão fundamental era garantir um melhor nível de vida aos cabo-verdianos (VICENTE LOPES, 2015).

Concordando com esse argumento, Koudawo (2001) afirma que, em Cabo Verde, as elites foram "leais" às mudanças democráticas que começaram a ser realizadas na década de 1990, apresentando um caráter mais progressista do que as elites de outros PALOP, conforme se observa no excerto a seguir:

\begin{abstract}
Aristides Lima falou em "lealdade" para caracterizar a atitude dos dirigentes do PAICV, que conduziram a transição ordenada e bem-sucedida de Cabo Verde para o pluralismo e as primeiras eleições livres que vieram a perder. Quer dizer que, por comparação, pode-se falar de "deslealdade" para caracterizar a atitude dos dirigentes do PAIGC, que conseguiram manobrar durante três anos e meio nas águas agitadas e por vezes turvas (17 de Março) da transição (guineense) para conservar o controle do poder? Nada é mais evidente (KOUDAWO, 2001, p. 163).
\end{abstract}

Da mesma forma, as elites são tomenses também sabiam que, pelos limitados recursos naturais do país, era necessário ter adaptabilidade para compreender as mudanças internacionais e transformar a sua arena doméstica de modo a angariar mais investimentos. Nesse sentido, Espírito Santo (2013a) afirma que:

[...] os pequenos estados insulares não devem temer a abertura ao exterior, porque é através dela que conseguem obter mais facilmente recursos para o seu desenvolvimento. Por isso, o caminho deve ser o aumento da cooperação e uma diplomacia agressiva concertadas com base em objetivos planeados de 
desenvolvimento e no quadro da divisão internacional do trabalho, boa governação e um diálogo interno e externo permanentes e descomplexados [...] E quanto menor for a dimensão, maiores serão as dificuldades dum pequeno país insular, e maiores serão as suas necessidades de abertura ao exterior como forma para a sua sobrevivência e viabilidade. Mas essa abertura tem de ser concebida no quadro de uma adequada estratégia de desenvolvimento sustentado que não prejudique os valores sociais e culturais locais congruentes com o desenvolvimento humano local (ESPÍRITO SANTO, 2013a, p. 82).

Além disso, é importante destacar o posicionamento das elites moçambicanas no início da democratização, notadamente da RENAMO, que apresentaram uma expressiva flexibilidade ao aceitarem os resultados das eleições de 1994, que foram imersas em um contexto de grande vulnerabilidade doméstica pós-guerra civil (CHABAL, 2006). Dessa forma, tem-se que a vontade política e a flexibilidade das elites do país podem ser assinaladas como alguns dos fatores mais importantes que explicam o relativo sucesso da sua democratização. Já em Angola, observa-se um cenário diametralmente oposto, tendo em vista que nas suas primeiras eleições presidenciais, a UNITA, de Jonas Savimbi, não aceitou a derrota e reiniciou a guerra civil, que entraria na sua fase mais violenta e perduraria por mais dez anos.

De acordo com a análise realizada, tem-se que as elites políticas de Cabo Verde, São Tomé e Príncipe e Moçambique estavam mais comprometidas com as mudanças em prol da democracia e da liberdade, já iniciando significativas mudanças no final da década de 1980. Destarte, esse resultado é apresentado na tabela a seguir:

Tabela 41 - Análise do perfil das elites políticas dos PALOP

\begin{tabular}{|l|l|l|l|l|l|}
\hline Variável/ País & $\begin{array}{l}\text { Cabo } \\
\text { Verde }\end{array}$ & $\begin{array}{l}\text { São Tomé e } \\
\text { Príncipe }\end{array}$ & Moçambique & $\begin{array}{l}\text { Guiné- } \\
\text { Bissau }\end{array}$ & Angola \\
\hline $\begin{array}{l}\text { Direitos políticos } \\
\text { e liberdades civis } \\
\text { (t2) }\end{array}$ & $\mathrm{S}$ & $\mathrm{S}$ & $\mathrm{S}$ & $\mathrm{N}$ & $\mathrm{N}$ \\
\hline
\end{tabular}

Fonte: Tabela elaborada pela autora. 


\section{VIA 16: Guerra civil}

A presença de guerras civis no período do pós-independência constitui um dos principais fatores diretos que explicam a instabilidade social, política e econômica dos PALOP continentais. Conforme mencionado anteriormente, as guerras civis ocorreram somente nos PALOP continentais, refletindo cenários de violência e destruição que se prolongaram por um longo período de tempo nas realidades de Angola e Moçambique. No caso da Guiné-Bissau, mesmo a guerra tendo se apresentado breve e já durante o período da democratização, as instabilidades causadas pelo confronto permanecem até os dias atuais (TVBRASIL, 2015). Por ter se desdobrado entre 1998 e 1999, o referido conflito será analisado de maneira específica no próximo capítulo.

\section{Guerra civil em Angola}

A independência angolana foi negociada por meio do Acordo de Alvor, assinado no dia 31 de janeiro de 1975, no qual Portugal reconheceu tanto o MPLA quanto a UNITA e a FNLA como os "únicos representantes legítimos" do país. Nesse ínterim, previa-se um cessar-fogo imediato e a anistia a todos os atores envolvidos no conflito. O documento também estabelecia a instauração de um governo transitório, que seria constituído por três representantes de cada grupo de libertação. No âmbito das forças armadas, a representação dos movimentos também seria paritária. Por fim, o acordo tinha como objetivo a realização de eleições em outubro de 1975, sendo que somente os membros do MPLA, UNITA e FNLA poderiam se candidatar para a Assembleia Constituinte (AGOSTINHO, 2011). O acordo dependia da vontade política de todas as partes envolvidas para que pudesse ser exequível, mas o perfil das elites angolanas era de pouca flexibilidade e reduzida inclinação para o compartilhamento do poder, o que gerou muitas dúvidas sobre os resultados da pactuação.

Desde o momento no qual entrou em vigor, o Acordo não foi cumprido, fazendo com que se iniciasse no território angolano a guerra civil mais longeva da história da África, que perdurou até 2002. Para Agostinho (2011), "se realmente esse acordo fosse obedecido, talvez o rumo da história de Angola não seria tão dramático" (AGOSTINHO, 2011, p. 30). Em parte, o conflito se explica porque entre os meses que separaram a 
assinatura do Acordo e a data da independência, marcada para 11 de novembro de 1975, cada movimento começou a se organizar e articular no espectro dos mais variados segmentos sociais, sendo que o MPLA incorporou um forte caráter militar a essas novas alianças, a saber:

\begin{abstract}
O MPLA procurou antecipar-se aos seus oponentes, implantando-se em Luanda, nas principais estruturas administrativas, nos quadros das empresas, nos meios intelectuais, em confronto com os seus concorrentes, favoreceu o seu diálogo com os membros do MFA, que ao contrário, e apesar dos seus esforços, se viam sempre em enormes dificuldades para estabelecerem ligações com a UNITA e a FNLA. Assim, os movimentos lançaram uma ampla ação de recrutamento dos militantes angolanos, acabados de licenciar pelo exército português e dos elementos dos vários tipos de forças auxiliares que estavam em vias de ser dispensados. Isto revelou a deliberada preocupação de reforçarem os seus efetivos armados, sem terem em consideração os limites e as metodologias reguladas pelo texto aprovado no Alvor, para a constituição das forças militares mistas. Era o prenúncio da confrontação armada que começava a desenhar-se e a apresentar-se como inevitável (AGOSTINHO, 2011, p. 30).
\end{abstract}

Além disso, a falta de vontade política e as crises internas em Portugal fizeram com que o país não fornecesse o apoio necessário para a instauração do governo de transição angolano, que na prática não chegou a efetivamente exprimir resultados importantes. A instabilidade foi tão intensa, que no dia 9 de agosto, os membros da FNLA e da UNITA anunciaram que formalmente não fariam mais parte do Acordo. O DecretoLei $\mathrm{n}^{\mathrm{o}} 458 / \mathrm{A}-75^{52}$ do dia 22 de agosto do mesmo ano suspendeu parte do documento, fazendo com que a cena bélica do país fosse praticamente inevitável, principalmente levando em consideração que outros países do meio internacional já se encontravam amplamente dispostos a participar do confronto pelo poder (AGOSTINHO, 2011).

Cada movimento começou a atuar no espaço geográfico onde exerciam maior influência, preparando-se para invadir as áreas ocupadas pelos outros grupos de libertação. A FNLA baseava-se no norte do país e contava, no âmbito fronteiriço, com o apoio do Zaire, que era simpático à ideologia anticomunista do grupo. Já o MPLA focalizava-se na parte oriental e em Luanda, obtendo o apoio do Congo, que vivenciava

\footnotetext{
${ }^{52} \mathrm{O}$ artigo primeiro do referido Decreto, que foi assinado pelo presidente português Francisco da Costa Gomes (1974-1976), menciona que: "Considera-se transitoriamente suspensa a vigência do Acordo de Alvor, concluído em 15 de Janeiro de 1975 entre o Estado Português e a Frente Nacional de Libertação de Angola (FNLA), o Movimento Popular de Libertação de Angola (MPLA), e a União Nacional para a Independência Total de Angola (UNITA), no que diz respeito aos órgãos de governo de Angola" (DecretoLei ${ }^{\circ}$ 458/A-75, 1975).
} 
um regime marxista. Por sua vez, a UNITA encontrava-se forte na região central de Angola, na qual se fortalecia na parte meridional do país com o apoio do sudoeste africano e, ocasionalmente, da África Sul.

\begin{abstract}
Na cimeira de Penina e Mombaça, Neto propôs o armamento da população negra, com o argumento de que esta gente necessitava de meios para se defender da agressão da população branca. Holden Roberto e Savimbi estiveram de acordo. (...) Neto quis armar o poder popular de uma forma legal, que se viria a impor não apenas contra a população branca, mas também contra a UNITA e contra a FNLA [...] O MPLA procurou desenvolver uma política de poder popular totalitário, a curto, a médio, e a longo prazo, consentidas pela ingenuidade dos outros líderes. A violência tomou conta do território nacional, e oportunamente o MPLA expulsou os outros movimentos da capital, de modo a envergar o seu poder em Angola (AGOSTINHO, 2011, p. 35).
\end{abstract}

Ao longo dos seus 27 anos, o conflito teve algumas interrupções, sendo possível dividi-lo em três fases distintas: a) 1975 a 1991; b) 1992 a 1994 e c) 1998 a 2002. Assim como a guerra de independência, a guerra civil angolana estava fortemente inserida no contexto da Guerra Fria. Tanto a FNLA, que tinha como líder Holden Roberto, quanto a UNITA, que era presidida por Jonas Savimbi tinham o apoio dos EUA. Enquanto isso, o MPLA, que era presidido por Agostinho Neto, contou com o suporte financeiro e militar dos soviéticos e cubanos. Os primeiros confrontos da guerra civil ocorreram em março de 1975, entre o MPLA e a FNLA (AGOSTINHO, 2011).

Conforme a data da independência ia se aproximando, o confronto pelo domínio da região de Luanda começava a se intensificar. Nesse contexto, a FNLA havia unido forças à UNITA no combate ao MPLA, que já contava com o apoio dos cubanos. A Batalha de Luanda resultou na vitória do MPLA que, por ser o único movimento presente na capital para proclamar a independência no dia 11 de novembro, acabou assumindo a liderança do país na figura de Agostinho Neto, que se tornou presidente da República Popular de Angola. No mesmo dia, na cidade de Huambo, a FNLA e a UNITA proclamaram um governo paralelo, a República Democrática de Angola. Enquanto o primeiro foi amplamente reconhecido internacionalmente, o segundo apresentou inúmeras fraturas internas e acabou se desfazendo. Nesse cenário de profunda instabilidade, o posicionamento de Portugal foi de não-intervenção, a saber:

Entretanto, se Portugal tivesse decidido controlar o processo de descolonização, naturalmente teria adiada a data da independência. A verdade é que o governo português estava decidido a abandonar Angola, utilizando a data da independência como mudança e retirada das suas tropas. $\mathrm{O}$ que ficou 
certo, nessa fase final da descolonização portuguesa, foi o seu fracasso em contornar a situação da ex-colónia, e "lavando as mãos" da situação, deixou a resolução dos problemas na mão dos nacionalistas angolanos (AGOSTINHO, 2011, p. 39).

A contestação da FNLA e da UNITA ao poder do MPLA refletiu-se em inúmeras ofensivas, que se justificavam com o combate ao comunismo em Angola (AGOSTINHO, 2011). Duas semanas depois da independência, o conflito já tinha 40.000 mortos e aproximadamente um milhão de desabrigados, com a migração para o exterior dos quase 400.000 brancos que viviam no país (GLOBO, 2013). Com a morte de Agostinho Neto em 1979, José Eduardo dos Santos ascendeu ao poder do MPLA, tendo como uma das primeiras ações o abandono do acordo de cessar-fogo com Savimbi. Esse período marcou o aprofundamento da Guerra Fria, com maiores confrontos entre os blocos capitalista e comunista (HORING, 2015).

Em 1990, MPLA e UNITA retomaram as negociações de paz na cidade de Évora, em Portugal, com o apoio dos portugueses, soviéticos e norte-americanos. Ficou estabelecido que, assim que se instaurasse o cessar-fogo e que as eleições fossem organizadas, o apoio militar internacional para a guerra se encerraria. Como resultado, em 1991 foi assinado o Acordo de Bicesse, no qual: a) a UNITA reconheceria o poder do MPLA em Angola; b) os dois exércitos seriam aglutinados nas Forças Armadas de Angola (FAA) e c) o MPLA iniciaria o processo de democratização, com o estabelecimento de eleições para setembro de 1992. O período que separou a assinatura do acordo e a data do referido pleito eleitoral foi de paz no país. As eleições ocorreram e foram classificadas como livres e pacíficas pelos observadores da ONU. No espectro presidencial, nenhum candidato conseguiu a maioria absoluta na votação, sendo que José Eduardo dos Santos obteve $49,57 \%$ dos votos e Savimbi, 40,07\%. Pautando-se em alegações de fraudes eleitorais, Savimbi retira o seu exército da FAA e retoma a guerra civil, que perdurará por mais dez anos, encerrando-se somente com a sua morte em 2002 (HORING, 2015).

Para Soderberg e Ohlson (2003), a continuidade da guerra civil em Angola ocorreu em 1992 porque as suas elites não estavam dispostas a criar um espaço no qual o poder pudesse ser compartilhado. O desenho do sistema político do país encontrava-se pautado em um mecanismo de "winner-take-all" fez com que o resultado das eleições fosse rejeitado e que o conflito retornasse por mais uma década, conforme se observa no 
excerto a seguir ${ }^{53}$. Destaca-se que essa característica ainda permanece no cenário político angolano, no qual o mesmo partido político, o MPLA, governa o país desde 1975.

\begin{abstract}
Many analysts have argued that the one of main reason why the Bicesse peace agreement in 1992 in Angola between the Movimento Popular de Libertacao de Angola (MPLA) and the Uniao Nacional para a Independencia Total de Angola (UNITA) failed, was the design of the political system. The political system envisaged a strong presidential system and thus, in effect, the presidential election took the form of a "winner-take-all" system. Prior to the elections, both parties were confident to win, and therefore rejected any proposals about introducing a political system based on power sharing. When the early results indicated that UNITA had lost both the legislative and the presidential votes, the party rejected the results and declared the elections fraudulent. Short thereafter UNITA resumed its military campaign and Angola slipped back into full-fledged war. One lesson commonly derived from the Angolan debacle concerns the dangers of winner-take-all constitutional models and the advisability of power sharing systems (SODERBERG; OHLSON, 2003, p. 35).
\end{abstract}

O acordo de Bicesse gerou uma polarização ainda maior da sociedade, em um contexto no qual não foram feitas leis que regulamentassem a transição e nem mesmo um governo de coalizão. Em 1993, a UNITA dominava 75\% do país, incluindo algumas regiões petrolíferas e produtoras de diamantes. Os impasses para a negociação da paz entre UNITA e MPLA geraram inúmeros impactos econômicos, fazendo com que os norte-americanos retirassem, nesse mesmo ano, o seu apoio ao grupo de Savimbi. Contudo, o financiamento militar do partido vinha primordialmente das minas de diamantes de Lunda Norte, o que permitiu a continuação do conflito. Na década de 1990, a guerra civil apresentou uma clara distinção na administração dos recursos naturais do país. Enquanto a UNITA detinha a maior parte das receitas da extração dos diamantes, o MPLA controlava o petróleo. Destarte, o fim da Guerra Fria evidenciou a fase mais violenta do conflito, no qual a UNITA transfigurou-se em uma guerrilha de "senhores da guerra", na qual a fome era utilizada como um instrumento de combate (HORING, 2015). Ao descrever a atuação de Savimbi no período final da guerra, Horing (2015) descreve a seguinte situação:

Savimbi se transformou em um senhor da guerra, nos anos 1990, quando adotou estratégias que se baseavam em suas conexões políticas para acumular riqueza e construir um exército pessoal e seguidores políticos. Os senhores da guerra, segundo a definição do autor, são líderes rebeldes que costumam emergir em regimes autoritários, sendo uma expressão da expansão da

\footnotetext{
${ }^{53}$ Esse aspecto conecta-se intimamente à variável referente ao perfil das elites políticas, tendo em vista que, não somente a elite angolana, mas também a guineense e a moçambicana apresentam como característica a dificuldade em compartilhar o poder.
} 
competição política que previamente teria existido nesses países. Visando tomar o controle do Estado, fazem-no através do controle e expansão de redes informais de comércio clandestinas e violência política. O fator mais importante para sua emergência é a presença de um sistema com importantes clivagens políticas e no qual a autoridade é definida a partir de relações patrimonialistas e lealdades pessoais, característica da política em Angola (HORING, 2015, p. 64).

Em 1994, instaurava-se o Protocolo de Lusaka, no qual foram estabelecidos, além do cessar-fogo, a legitimação do Acordo de Bicesse e das eleições de 1992. Esse momento marcou um início da mudança estrutural da política do "winner-take-all", estabelecendo, no ano de 1997, um Governo de Unidade e Reconciliação Nacional (GURN). Contudo, o Protocolo não obteve êxito, e mais uma vez o confronto se iniciou, marcando o terceiro e último momento da guerra civil angolana.

Nos anos seguintes, a UNITA passou a sofrer inúmeras sanções internacionais, e a guerra continuou o seu alto grau de violência, com a expansão das atividades das FAA nas áreas rurais e destruídas do país. O conflito continuou até a morte de Savimbi e do seu suplente, Antonio Dembo, que ocorreu no ano de 2002. Sem uma liderança no cerne do seu oponente, o MPLA declarou de maneira unilateral o fim das investidas militares, instaurando o Acordo Militar de Luena, que estabeleceu três questões principais: a) a desmilitarização da UNITA; b) a reintegração da UNITA à arena política e c) a anistia para todos os crimes. O Acordo foi assinado entre Abreu Karmoteiro, da UNITA, e Armando da Cruz e Neto, representando o MPLA.

A guerra civil angolana mostrou-se muito mais complexa do que a bipolaridade causada pela Guerra Fria, refletindo a fragmentação histórica dos interesses das suas elites políticas e dos seus nacionalismos (HORING, 2015). Além disso, a análise do referido conflito permite compreender a expressiva dificuldade que o país teve em iniciar o seu processo de democratização no meio de um confronto doméstico de enormes dimensões políticas, econômicas e sociais. As instabilidades do país dificilmente permitiriam que fosse instaurado um regime democrático enquanto ainda eram realizadas disputas militares pelo poder, que perduravam desde o pós-independência.

A guerra civil em Angola teve dois milhões de mortos, 1,7 milhão de refugiados, 80 mil mutilados e milhões de minas espalhadas por todo o seu território (GLOBO, 2013). A guerra exerceu grande impacto direto e indireto não somente na estabilidade política, 
mas também nas realidades sociais e econômicas da cena angolana. Rodrigues (2012) demonstra alguns dos efeitos de médio e longo prazo do conflito para o país na atualidade, a saber:

\begin{abstract}
As consequências da guerra são, contudo, ainda muito claras e pertinentes para a análise da pobreza e do desenvolvimento angolano na atualidade. "Décadas sucessivas de conflito militar provocaram em Angola, não apenas perdas substanciais ao nível do capital físico (equipamentos, infra-estruturas, habitações) e humano, mas também determinaram efeitos que se combinaram entre si no sentido de uma redução do bem-estar da generalidade dos angolanos" [Lopes 2009: 63]. A maior parte destes efeitos estão diretamente relacionados com a pobreza e com as condições de vida da população: deslocações compulsivas, insegurança, insegurança alimentar, má nutrição, graves dificuldades no acesso à saúde e educação [Lopes 2009: 73]. A Estratégia de Combate à Pobreza do governo angolano aponta como principal consequência direta para a gravidade da pobreza rural a guerra, que limitou o acesso da população às áreas de cultivo e mercados e que destruiu os recursos dos camponeses; esvaziou o campo de mão-de-obra e fez afluir milhares de deslocados para as cidades [Governo 2005: 21] (RODRIGUES, 2012).
\end{abstract}

Após a análise da guerra civil angolana, o tópico seguinte será dedicado para o estudo do conflito no pós-independência que ocorreu em Moçambique.

\title{
Guerra civil em Moçambique - "A Guerra dos 16 Anos"
}

\begin{abstract}
Naquele lugar, a guerra tinha morto a estrada. Pelos caminhos só as hienas se arrastavam, focinhando entre cinzas e poeiras. A paisagem se mestiçara de tristezas nunca vistas, em cores que se pegavam à boca. Eram cores sujas, tão sujas que tinham perdido toda a leveza, esquecidas da ousadia de levantar asas pelo azul. Aqui, o céu se tornara impossível. E os viventes se acostumaram ao chão, em resignada aprendizagem da morte.

A estrada que agora se abre a nossos olhos não se entrecruza com outra nenhuma. Está mais deitada que os séculos, suportando sozinha toda a distância. Pelas bermas apodrecem carros incendiados, restos de pilhagens. Na savana em volta, apenas os embondeiros contemplam o mundo a desflorir. (MIA COUTO, Terra Sonâmbula, 1992, p. 02).
\end{abstract}

A Guerra Civil em Moçambique iniciou-se em 1976, nove meses depois do da sua independência de Portugal, encerrando-se somente em 1992. Para Jafar (2014), ela pode ser caracterizada como "um dos conflitos armados mais devastadores da parte sul 
da África Sub-Sahariana, que deixou o país destruído, paupérrimo, altamente endividado e mais dependente" (JAFAR, 2014, p. 03).

Depois da luta armada pela independência, que conforme mencionado no capítulo anterior foi realizada pela FRELIMO, evidenciaram-se os distintos posicionamentos dos indivíduos que participaram do combate pela libertação no âmbito do partido. Nesse ínterim, Jafar (2014) afirma que "uma parte dos membros e simultaneamente freedom fighters da FRELIMO discordou com a linha ideológica que essa seguiu - O Socialismo, dentre outros aspectos não consensuais no seio dos militantes da frente" (JAFAR, 2014, p. 14). Além desse grupo, a administração do pósindependência passou a ser questionada tanto pelos moçambicanos que ainda tinham uma forte conexão com o governo colonial português (notadamente as chefias tradicionais ${ }^{54}$ ) quanto pela Resistência Nacional de Moçambique (RENAMO), grupo criado em 1976 e liderada por André Matsangaíssa, que se opunha fortemente ao regime marxista monopartidário liderado por Samora Machel (CAMPOS, 2009).

Os primeiros conflitos que marcaram o início da guerra decorreram alguns meses depois da independência, em um confronto entre a FRELIMO e a recém-criada RENAMO, que era caracterizada no seu primeiro momento como "uma unidade mercenária de um exército colonial branco" (JAFAR, 2014, p. 15). Este grupo obteve grande apoio da Rodésia e da África do Sul, que se opunham ao governo moçambicano por ele auxiliar os movimentos de resistência contra o "apartheid", que vigorava em ambos os países. O fim do governo de Ian Smith na Rodésia fez com da África do Sul o seu único aliado expressivo na região (CAMPOS, 2009).

No decorrer da guerra, uma parte significativa da sociedade aderiu à RENAMO, notadamente no meio rural. Grande parcela dos opositores discordava do modelo de desenvolvimento sustentado pela FRELIMO, apelidado de "Estado Aldeião", que se focalizava, entre outros fatores, na coletivização dos meios de produção e na construção de aldeias comunais. Campos (2009) afirma que essa questão fomentou inúmeras tensões domésticas, expressas no seguinte excerto de Florêncio (2002):

\footnotetext{
${ }^{54}$ Para Campos (2009), os chefes tradicionais eram vistos como "oportunistas, corruptos, que haviam lucrado muito com o seu papel de cobradores de impostos, recrutadores de mão de obra e agentes de policiamento local durante o colonialismo português" (CAMPOS, 2009, p. 80).
} 
É o processo de aglomeração das populações rurais em aldeias comunais, que vai provocar uma forte desestruturação das condições de vida, e de reprodução social, econômica e política, dessas populações. O processo de aldeamento provocou fricções e lutas entre sectores das próprias sociedades rurais, quer pela definição dos locais de edificação das aldeias, quer pelo controlo das coperativas de consumo [FLORÊNCIO, 2002, p.354] (CAMPOS, 2009, p. 82)

\title{
A tentativa da FRELIMO de reorganizar as relações hierárquicas e estruturas
} sociais já estabelecidas nos contextos tradicionais alcançou patamares extremos, tais como a proibição de manifestações culturais e religiosas. Campos (2009) exemplifica a dimensão dessas perseguições por meio do testemunho de uma senhora idosa sobre a repressão pela sua comunidade, na qual afirma que:

\begin{abstract}
Foram os mapéwé (chefes) os que deram origem à comunidade, através da epepa (farinha de milho oferecida aos ancestrais) (...) Graças à epepa, cada chefe da linhagem humu tem a permissão de se comunicar com os ancestrais do seu grupo, e a comunidade nunca sofreu desastres. Esta guerra que sofremos foi provocada pelos "contrários". Não podíamos fazer nada: não podíamos depositar a epepa, nem ir aos lugares sagrados, porque tínhamos medo. Quando éramos pegos depositando a epepa, íamos presos. É por isso que deixamos de depositar a epepa: para deixar que os donos (FRELIMO) fizessem o que quisessem, para deixar os akunha (brancos) fazer o que bem entendessem. Deixamos de colocar a epepa, e por isso quando a guerra chegou em nossa comunidade, ninguém pôde evita-la. Chegou de surpresa, porque tínhamos medo de ir aos lugares sagrados para rezar e evitar a guerra. Mas, se tivéssemos ido rezar nesses lugares e se as autoridades tivessem encontrado a epepa lá, teriam nos prendido. É por isso que a guerra veio e entrou em nossa terra violentamente, chegando ao nosso povo. A gente se dispersou. A guerra nos destruiu. Aqueles que tinham epepa em casa, alguém veio e a queimou. Os ekhavete (tambores que simbolizam o poder dos chefes da linhagem) foram quebrados, foram os soldados da FRELIMO que o fizeram. Quando a epepa estava em uma garrafa, quebravam a garrafa, e o pouco que sobrava, eles nos faziam diluir em água e beber. Estas foram coisas muito ruins de acontecerem, e por isso esta terra está arrasada. Ficamos muito tristes, esperávamos o fim. Porque eles destruíram todas as nossas coisas, quebraram tudo, queimaram tudo, e a guerra chegou violentamente... (GEFFRAY, 1990, apud CAMPOS, 2009, p. 83).
\end{abstract}

A opressão no campo fez com que um grande montante populacional começasse a migrar para as áreas urbanas, ocasionando não somente um aumento da pobreza, como também diminuindo de maneira expressiva a produção agrícola do país. Dessa forma, na década de 1980, a RENAMO foi se tornando cada vez mais autônoma, ganhando um crescente apoio das áreas rurais e dominando uma vasta parte do território moçambicano. Ao atuar por meio de guerrilhas, a estratégia desestabilizadora do grupo era destruir pontes, estradas e linhas férreas de regiões ligadas à FRELIMO, fator que gerou 
significativos impactos econômicos para o governo (CAMPOS, 2009). Além disso, outro instrumento de guerra utilizado pelo grupo era pautado na criação de um mecanismo cruel de recrutamento militar, no qual os membros da guerrilha permaneceriam leais à RENAMO, a saber:

\begin{abstract}
Grande parte do exército da RENAMO era constituída por jovens indicados pelas autoridades tradicionais na sua zona de influência, ou era fruto das investidas nas aldeias em que adolescentes eram raptados. Os indivíduos recrutados pela RENAMO eram sujeitos a experiências de choque que visavam a torná-los aptos ao combate. Primeiramente, eram obrigados a matar animais e, mais tarde, pessoas, inclusive da própria família. Essa situação fez com que os jovens que cometessem esses crimes não voltassem para as zonas controladas pelo governo, mesmo com a possibilidade de fuga. Eles tinham consciência de que, se fossem pegos pela FRELIMO, ainda que alegassem o rapto e a obrigatoriedade de participar dessas investidas de extrema violência, seriam julgados e executados como terroristas. Dessa forma a RENAMO criou uma força bélica "leal" (CAMPOS, 2009, p. 84).
\end{abstract}

O ano de 1983 marcou um importante momento para o conflito. Por meio do Acordo de Nkromati, a África do Sul se comprometeu a retirar o seu apoio à RENAMO, que começou a se enfraquecer. Três anos depois, houve a morte, em um acidente de avião, do presidente Samora Machel. O seu cargo foi sucedido por Joaquim Chissano, que iniciou a fase mais violenta do conflito, com massacres condenados internacionalmente. Contudo, a queda soviética impactou o orçamento bélico da FRELIMO, tendo em vista que os recursos enviados para o partido foram significativamente reduzidos. Jafar (2014) afirma que, já em meados da década de 1980, as negociações com o Ocidente aprofundaram-se, marcadas pelo iminente fim da Guerra Fria, que era caracterizado como "a desagregação da URSS e do Socialismo e, por conseguinte, o corte de ajuda aos países amigos como Moçambique" (JAFAR, 2014, p. 04). Em 1987, o auxílio econômico advindo do FMI e do Banco Mundial baseava-se nos seguintes pilares: a) abandono da orientação política marxista; b) controle da inflação; c) redução da máquina estatal; d) abertura aos investimentos externos. Como consequência, em 1989, a FRELIMO oficialmente abandonou o marxismo-leninismo. A inserção de Moçambique no contexto capitalista fez com que muitos dos recursos internacionais direcionados para a RENAMO também fossem mitigados. Nesse cenário, a comunidade internacional tinha como interesse o fim da guerra civil, fator que fomentou o início das negociações entre ambas as partes em 1990 (CAMPOS, 2009). 
Depois de quase dois anos, foi assinado o Acordo de Paz de Roma, em outubro de 1992, mediado pela comunidade religiosa de Santo Egídio. Além da ampla anistia para os envolvidos nos dois lados do conflito, o documento também estabeleceu que "haveria a garantia dos direitos básicos individuais, tais como: liberdade de crenças, opinião e associação; pluralismo partidário; independência dos tribunais; eleições livres e secretas; respeito aos direitos cívicos e humanos" (CAMPOS, 2009, p. 85). Posteriormente, também haveria a criação de um exército nacional e o estabelecimento de eleições, que ocorreram no ano de 1994.

De maneira direta ou indireta, a guerra gerou um milhão de mortos tanto em combate quanto em crises de fome, além de resultar em cinco milhões de deslocados internos. Mia Couto (2015) afirma que, durante os 16 anos de guerra, o país ficou devastado, a saber:

A guerra inviabilizou tudo, a estrada, o comércio, a produção. Este país ficou partido, é como se tivesse ficado paralisado. E saíamos para a rua sem saber o que tínhamos para comer no jantar ou no almoço, porque não havia absolutamente nada nas lojas (MIA COUTO, 2015, s.p.).

Nesse contexto, Moçambique iniciou o seu processo de democratização devastado após o conflito armado. Contudo, ao contrário do que ocorrera em outros países africanos, as eleições de 1994 foram consideradas um sucesso, culminando com a vitória de Chissano, da FRELIMO (44,33\% dos votos). Apesar do questionamento inicial da RENAMO em relação à existência de fraudes eleitorais, o impasse encerrou-se de maneira pacífica e o resultado do pleito foi aceito por ambos os competidores. Esse cenário único foi descrito por Chabal (1996) da seguinte maneira: "Mozambique is singular in that it is the first country in Africa where civil war has been ended by a successful multi-party election in which the two former enemies participated freely" (CHABAL, 1996, p. 58). O posicionamento das elites moçambicanas nesse período histórico revelou a sua maior flexibilidade política em relação às elites angolanas. Esse comportamento pode ser explicado por diversos motivos: primeiramente, houve uma grande pressão internacional para que as elites do país selassem a paz e realizassem eleições existosas. Em segundo lugar, tem-se que essas elites compreendiam que a implantação de uma boa governança se mostrava essencial para angariar recursos externos, que seriam fundamentais para a reconstrução do país no pós-guerra civil. 
Contudo, apesar da grande flexibilidade inicial das elites moçambicanas, na cena política do país ocorreu um fato semelhante ao observado em Angola, ou seja, somente um partido político, a FRELIMO, se mantém no poder há mais de 40 anos, mesmo com a presença de um sistema multipartidário e com eleições periódicas. Nesse ínterim, destaca-se que os processos de democratização desses e dos outros PALOP serão elucidados de maneira mais aprofundada no próximo capítulo.

\section{Guerra Civil na Guiné-Bissau - "Guerra de 7 de Junho"}

Ao contrário das guerras civis em Angola e Moçambique, o conflito guineense não esteve inserido no contexto da Guerra Fria, iniciando-se somente em 1998, quatro anos depois do país ter começado o seu processo de transição democrática. Nesse ínterim, destaca-se que a análise do referido conflito se encontra nessa parte da tese porque a variável "guerra civil" abrange não somente o período do partido único, mas todo o contexto do pós-independência dos PALOP.

Desde o fim da guerra colonial, as relações internas do PAIGC caracterizam-se por profundas divergências, que resultaram em uma significativa instabilidade na GuinéBissau nos seus mais de 40 anos como Estado independente. Nesse contexto, inúmeras tensões sociais instauraram no país uma cultura política de rupturas violentas. As primeiras eleições presidenciais guineenses ocorreram em 1994 e, conforme será abordado de maneira mais aprofundada no próximo capítulo, o pleito teve como vencedor o candidato do PAIGC Nino Viera. O cenário de democratização pós-1994 refletiu na continuidade e no agravamento das inúmeras convulsões sociais supracitadas, com ênfase nos crescentes atritos entre o presidente eleito (que se encontrava no poder desde 1980) e determinados setores militares. O estopim dessas animosidades ocorreu no dia 7 de junho de 1998, quando o Brigadeiro Ansumane Mané liderou um golpe militar contra o presidente Vieira. Nesse momento, iniciou-se um conflito político-militar que perdurou 11 meses, reunindo as forças governamentais de Vieira de um lado e os alguns militares e segmentos sociais revoltosos de outro (LOPES, 2010). Nesse ínterim, a natureza do confronto é descrita da seguinte maneira: 
políticos e acadêmicos revoltados com o rumo que o país seguia se juntaram a estes militares. Foram essas pessoas que transformaram aquilo que era um "simples" ajuste de contas em conflito, opondo de um lado o presidente Nino Vieira e de outro uma ala das Forças Armadas da autoproclamada Junta Militar, comandada pelo Ex-chefe de Estado Maior General das Forças Armadas, o Brigadeiro Ansumane Mané (LOPES, 2010, p. 12).

No âmbito internacional, Nino Vieira obteve o apoio do Senegal e da Guiné, fator que não impossibilitou a sua queda no ano de 1999. Como resultado, ele se refugiou em Portugal e os militares indicaram o Presidente da Assembleia Nacional Popular, Malam Bacai Sanhá, para a presidência interina do país. Nesse mesmo período, houve o cessar-fogo com a preparação de eleições e o regresso dos milhares de refugiados ao país (SANGREMAN et al., 2006).

De acordo com o exposto acima, observou-se que o cenário de guerras civis após as independências surgiu somente nos PALOP continentais, que por sua vez tinham perpassado cenários de guerras de libertação. Os PALOP insulares não vivenciaram quaisquer conflitos armados em seus territórios, fator que ajudou a impulsionar tanto o seu crescimento econômico quanto o seu desenvolvimento social e a sua estabilidade política. Nesse contexto, a análise da tabela sobre a presença de guerra civil nos PALOP após 1975 reflete um resultado positivo para Angola, Moçambique e Guiné-Bissau (destacando-se que a guerra guineense apresentou um escopo temporal e uma dimensão de mortes e destruição expressivamente menor no que os conflitos angolano e moçambicano) e negativo para as realidades de Cabo Verde e São Tomé e Príncipe, a saber:

Tabela 42 - Análise da presença de guerra civil nos PALOP no pósindependência (1975-2015)

\begin{tabular}{|l|l|l|l|l|l|}
\hline Variável/ País & $\begin{array}{l}\text { Cabo } \\
\text { Verde }\end{array}$ & $\begin{array}{l}\text { São Tomé e } \\
\text { Príncipe }\end{array}$ & Moçambique & $\begin{array}{l}\text { Guiné- } \\
\text { Bissau }\end{array}$ & Angola \\
\hline Guerra civil & $\mathrm{N}$ & $\mathrm{N}$ & $\mathrm{S}$ & $\mathrm{S}$ & $\mathrm{S}$ \\
\hline
\end{tabular}

Fonte: Tabela elaborada pela autora.

O presente capítulo permitiu compreender os desdobramentos sociais, políticos e econômicos do regime de partido único na trajetória dos PALOP, evidenciando as semelhanças e as diferenças presentes no cenário de cada Estado estudado. No próximo 
Capítulo, serão analisados os processos de democratização desses países, evidenciando os seus resultados na variável independente principal, na variável externa e nas variáveis independentes intervenientes em um espectro temporal de aproximadamente 25 anos. 


\section{CAPÍTULO 5 - ESTUDO DE CASO 3: A DEMOCRATIZAÇÃO DOS PALOP NO PÓS-GUERRA FRIA}

O presente capítulo tem como objetivo realizar um estudo de caso sobre a democratização dos PALOP, analisando comparativamente as variáveis referentes a esse período histórico de acordo com a cadeia causal exposta no Capítulo 2. Dessa forma, será

possível compreender as dinâmicas sociais, políticas e econômicas da África lusófona da década de 1990 até a atualidade. Na estrutura deste estudo, a variável independente principal, a variável externa, seis variáveis independentes intervenientes e finalmente, a variável dependente, serão abordadas, sendo o primeiro tópico pautado na "estabilidade social, política e econômica dos PALOP no início da democratização", e o último, na implantação da democracia liberal nesses países durante o referido período.

\section{Período histórico: início da democratização em 1990}

\section{VIP: Estabilidade social, política e econômica no início da democratização}

A variável "estabilidade social, política e econômica" refere-se ao contexto doméstico em que se encontrava cada PALOP no momento que eles iniciavam a sua democratização. Autores como Mosca (2001) compartilham a premissa de que os conflitos armados estão intrinsecamente ligados à instabilidade, sendo improvável o sucesso da democratização em cenários belicosos. Nesse ínterim, ele afirma que "é muito difícil existir democracia em guerra, será problemática a formação das nações sem a consolidação da paz, não é possível haver desenvolvimento em situação de profunda desestabilização" (MOSCA, 2001, p. 95).

Dessa forma, é possível compreender muitas das dificuldades enfrentadas por Angola, Moçambique e Guiné-Bissau, que vivenciaram em menor ou maior grau guerras civis na década de 1990. Nesse universo, destaca-se que a transição democrática moçambicana se iniciou efetivamente com as eleições de 1994, depois do fim da sua guerra civil. Em Angola, quase todo o período da década de 1990 foi permeado pela fase mais violenta do seu conflito doméstico. Já no caso guineense, a guerra se estabeleceu de 
maneira breve entre 1998 e 1999, depois do início da sua transição democrática, com uma intensidade mais reduzida do que a observada nos outros PALOP continentais. Por outro lado, ao analisar o caso de Cabo Verde e São Tomé e Príncipe, observa-se que o fato deles não terem apresentado conflitos armados nesse período pode ser um dos principais fatores que explicam a sua relativa estabilidade social, política e econômica, fazendo com que a democratização de ambos decorresse de maneira mais rápida e efetiva quando comparada aos outros PALOP.

Dessa forma, no espectro desta tese, a variável "estabilidade social, política e econômica" sintetiza os arranjos domésticos que abrangem a combinação de todas as variáveis independentes antecedentes que foram abordadas nos Capítulos 3 e 4. Assim, ela constitui uma variável que fornece maior parcimônia ao trabalho doutoral realizado, pois agrega em sua essência o universo social, político e econômico de cada PALOP, perpassando os períodos colonial, de partido único e, finalmente, do início da democratização. Para evitar repetições de um conteúdo que já foi extensamente abordado nos capítulos supracitados, o resultado da análise desta variável encontra-se representado na seguinte tabela:

Tabela 43 - Análise da estabilidade social, política e econômica dos PALOP no início da democratização

\begin{tabular}{|l|l|l|l|l|l|}
\hline Variável/ País & $\begin{array}{l}\text { Cabo } \\
\text { Verde }\end{array}$ & $\begin{array}{l}\text { São Tomé e } \\
\text { Príncipe }\end{array}$ & Moçambique & $\begin{array}{l}\text { Guiné- } \\
\text { Bissau }\end{array}$ & Angola \\
\hline $\begin{array}{l}\text { Estabilidade } \\
\text { social, política e } \\
\text { econômica }\end{array}$ & $\mathrm{S}$ & $\mathrm{S}$ & $\mathrm{N}$ & $\mathrm{N}$ & $\mathrm{N}$ \\
\hline
\end{tabular}

Fonte: Tabela elaborada pela autora.

\section{VEXT: Pressões internacionais para a democratização dos PALOP após o fim da Guerra Fria}

Conforme mencionado anteriormente, os PALOP vivenciaram de maneira intensa os efeitos da agenda da Nova Ordem Mundial ${ }^{55}$ após a década de 1990,

\footnotetext{
55 Nesse contexto, "a aplicação prática das perspectivas neo-wilsonianas fortaleceu a análise da nova configuração mundial ao focalizar temáticas como o revigoramento da questão democrática - ressaltando a busca pela democracia (causas e consequências redescobertas), o revigoramento do direito internacional, a redescoberta do papel das instituições internacionais, o ímpeto do princípio de autodeterminação dos cidadãos e a intensificação dos direitos humanos. (QUEIROZ, BRITTO, 2015, p. 12). Para Minillo (2012), o pós-Guerra Fria evidenciou os esforços ocidentais para a promoção da democracia e do liberalismo.
} 
principalmente com a diminuição significativa do apoio financeiro da URSS. As novas regras na arena política global demandavam um aporte de fatores internos e um posicionamento externo que nunca tinham feito parte do percurso formativo desses jovens Estados. A questão que se configurava nesse momento para essas antigas colônias portuguesas era: como se inserir e se adaptar ao novo tabuleiro internacional? A ajuda internacional era necessária, e a transição democrática delineava-se como um caminho que facilitador desse processo.

No decorrer da Guerra Fria, o posicionamento dos Estados Unidos em relação à África se modificou significativamente. De um continente com pouca importância estratégica, ele passou a ter relevância na agenda externa do país após a independência de Gana, em 1957 (FORTUNA, 1985). Essa nova perspectiva norte-americana em relação às questões africanas pode ser observada no excerto a seguir:

[Os EUA] no que diz respeito à África, não tinham aí grandes interesses, quer
econômicos quer mesmo estratégicos. Tinham-nos sim na América Latina, no
Canadá, no Médio e Extremo Oriente e na própria Europa. Os Estados Unidos
levavam quase à letra a expressão de Hugo - "No reino do desconhecido, a
África é o Absoluto". Isto é, para o novo poder hegemônico, a África era uma
questão menor, o colonialismo uma questão interna dos seus aliados e a
descolonização um processo visto, de início, com abertura e, depois, com
crescente preocupação e controlado liberalismo. Com efeito, à medida que
correm os "ventos da mudança", a África passa para os Estados Unidos, de
preocupação menor a assunto delicado. Não se opondo à descolonização, os
Estados Unidos têm mesmo uma posição aberta desde que os seus aliados
europeus mantenham boas relaçães com os novos poderes africanos, evitando
assim a criação de "vazios de poder", tão reprovados por qualquer poder
hegemônico (FURTADO, 1985, p. 495).

De acordo com a narrativa exposta no decorrer desta tese, após o fim Guerra Fria, o tipo de democracia que os doadores internacionais passaram a exigir dos países africanos era pautado no modelo liberal, no qual era demandada a implantação de um conjunto específico de direitos políticos e liberdades civis presentes nas estruturas democráticas Ocidentais. Depois de abandonar a configuração marxista dos seus Estados, cada PALOP iniciou a sua democratização de maneira própria e singular, de acordo com o contexto doméstico de cada realidade. A análise conjunta desses cinco países revela que houve um significativo aumento da ajuda oficial recebida após 1990 em todos eles, sendo esse valor proporcionalmente maior nos cenários onde os ganhos democráticos eram mais 
evidentes, notadamente em Cabo Verde, São Tomé e Príncipe e Moçambique ${ }^{56}$. Dessa forma evidencia-se uma grande correlação entre essas duas variáveis, conforme se observa na figura abaixo:

\section{Gráfico 10 - Ajuda oficial para o desenvolvimento e ajuda oficial recebida (em US\$) pelos PALOP de 1967 a 2015 (WORLD BANK, 2017)}

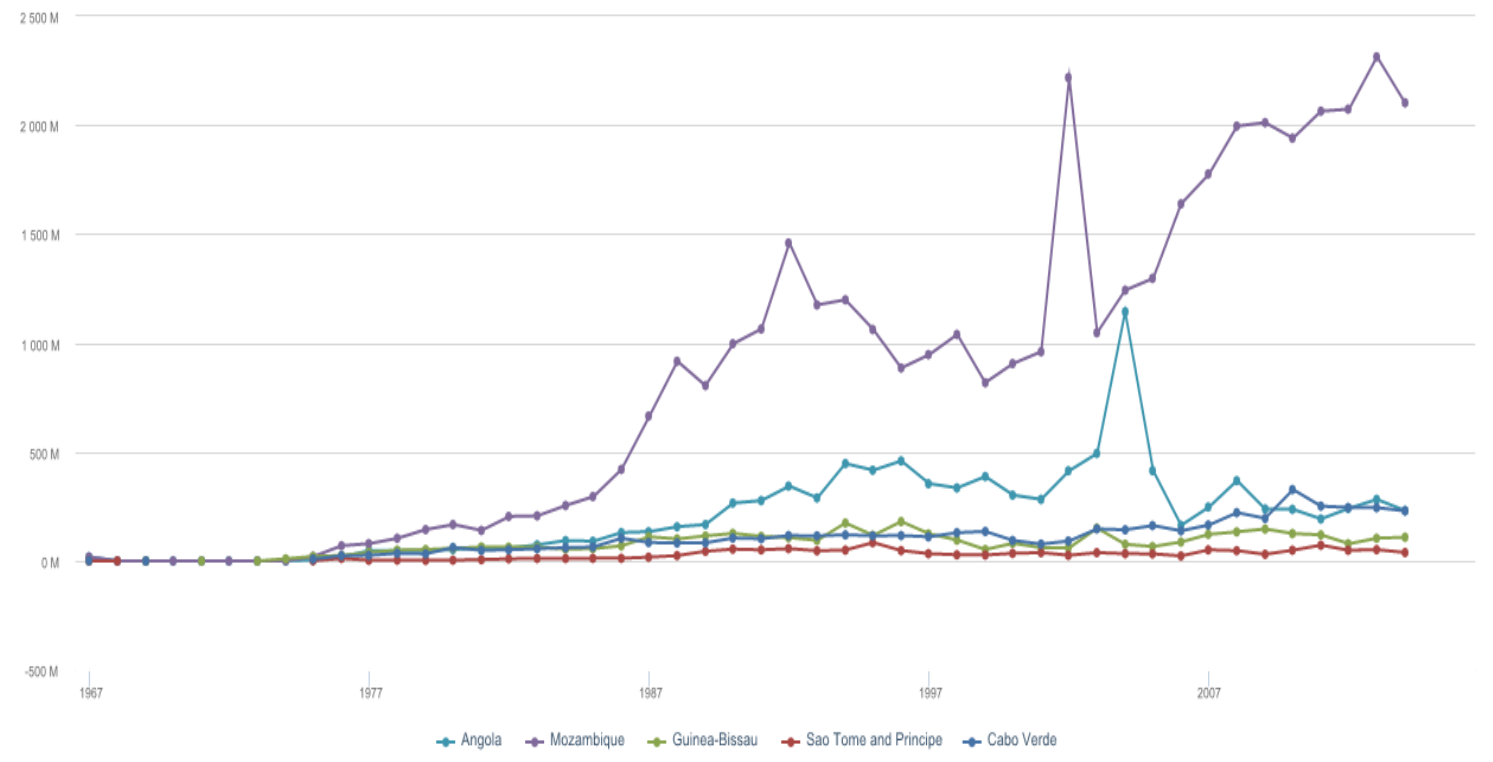

Fonte: BANCO MUNDIAL, 2017, s.p.

Após o início da democratização, cada PALOP trilhou a sua própria trajetória política, conferindo à democracia um caráter singular que impactou de maneira idiossincrática a sua relação de parceria estratégica com seus doadores internacionais. Cabo Verde e São Tomé e Príncipe, que já se estabeleceram como Estados livres desde a última década do século $\mathrm{XX}$, receberam vultuosos recursos financeiros externos $\mathrm{e}$ obtiveram um espaço de maior destaque no meio global devido a sua adaptabilidade ao novo cenário pós-bipolar. Por sua vez, Moçambique encontra-se em um complexo processo de transição democrática repleto de avanços e retrocessos, que consegue obter ajuda internacional e investimentos externos em grande parte devido à sua tentativa de adaptação ao regime democrático.

\footnotetext{
${ }^{56}$ No Anexo F é possível identificar essas mudanças de maneira detalha no escopo de cada PALOP.
} 
Já Angola apresenta um controverso processo de transição democrática, que possui impacto direto na sua inserção mundial e no seu histórico de recebimento de ajuda externa. Até 2002, o país dependia significativamente dos recursos de ajuda internacional, mas após o fim da Guerra Civil, a exploração do petróleo e diamante permitiu uma postura mais soberana em relação à agenda Ocidental e às pressões internacionais (CES, 2007). Já a Guiné-Bissau não conseguiu instaurar a democracia nem se adaptar à economia de mercado, tornando-se um Estado amplamente marginalizado na Nova Ordem Mundial. Devido às suas instabilidades internas, o país possui uma significativa dificuldade em angariar ajuda internacional.

Atualmente, o cenário que descreve o recebimento de ajuda externa dos PALOP caracteriza-se da seguinte maneira: no caso de Cabo Verde, a ajuda externa correspondeu a 30\% do PIB no ano de 2014, e em São Tomé e Príncipe, a 93\% das despesas de capital ${ }^{57}$. Já em Angola, depois da recuperação da sua economia no pós-guerra civil, a ajuda externa sofreu uma drástica redução, sendo considerada pelos seus governantes como “irrelevante" (CES, 2007). Em Moçambique, 50\% do orçamento de 2010 financiou-se por meio da ajuda externa (GIG, 2010). De acordo com o "Documento Quadro de Parceria 2008-2012”, “a Guiné-Bissau é muito dependente da ajuda internacional, que representa cerca de $12 \%$ do PIB e financia 96\% dos investimentos públicos” (DCP, 2012, p. 05). Entretanto, grande parte desses recursos não chega ao país devido às suas questões de organização doméstica, conforme se observa no discurso do ex-presidente brasileiro Luís Inácio Lula da Silva após o encontro da Comunidade Econômica dos Estados da África do Ocidente (CEDEAO), que ocorreu em 2010 em Cabo Verde, no qual afirmou que "Saibam os dirigentes de Guiné-Bissau que quanto mais divergência tiver, quanto mais brigas internas tiver, mais difíceis serão as ajudas que teriam que vir de outros países, sobretudo dos países mais desenvolvidos”. Além disso, Lula afirmou que a ajuda econômica brasileira à Guiné-Bissau seria condicionada à melhora dos seus conflitos internos (LIMA, 2010, p. 01).

A análise dessa variável permitiu compreender que, no final da década de 1980 e/ou início de 1990, todos os PALOP começaram a receber um significativo montante de

\footnotetext{
${ }^{57}$ Essas informações sobre o cenário econômico contemporâneo de Cabo Verde foram encontradas no site da Câmara de Comércio, Indústria e Turismo Portugal Cabo Verde (2015), já os dados sobre São Tomé e Príncipe estão disponíveis no relatório de 2014 do African Economic Outlook (GAMA, 2015).
} 
ajuda internacional, revelando a importância dessa variável externa para impulsionar a sua democratização, fenômeno que se encontra expresso na seguinte tabela:

Tabela 44 - Análise das pressões internacionais para a democratização dos PALOP

\begin{tabular}{|l|l|l|l|l|l|}
\hline Variável/ País & $\begin{array}{l}\text { Cabo } \\
\text { Verde }\end{array}$ & $\begin{array}{l}\text { São Tomé e } \\
\text { Príncipe }\end{array}$ & Moçambique & $\begin{array}{l}\text { Guiné- } \\
\text { Bissau }\end{array}$ & Angola \\
\hline $\begin{array}{l}\text { Pressões } \\
\text { internacionais para } \\
\text { democratização }\end{array}$ & $\mathrm{S}$ & $\mathrm{S}$ & $\mathrm{S}$ & $\mathrm{S}$ & $\mathrm{S}$ \\
\hline
\end{tabular}

Fonte: Tabela elaborada pela autora.

\section{Período histórico: decorrer da liberalização e transição democráticas após 1990}

\section{1: Liberalização política}

No conjunto dos PALOP, o presidente de São Tomé e Príncipe, Manuel Pinto da Costa, foi o primeiro a adotar o pluripartidarismo. Pouco tempo depois, o então presidente Aristides Pereira, de Cabo Verde, seguiu o mesmo exemplo. Em 1989, no momento em ocorreu a Cimeira dos Chefes de Estados dos Países Africanos de Expressão Portuguesa, São Tomé e Príncipe já havia referendado na sua Constituição a implantação do sistema multipartidário (VEIGA, 2014). Na obra "Minha Vida, Nossa História”, Aristides Pereira relata que o posicionamento são-tomense gerou desacordo entre os líderes dos PALOP continentais, tendo em vista que os governos moçambicano e angolano ficaram surpresos com a mudança política do arquipélago, como se observa na afirmação:

Essa questão foi muito mal vista, principalmente por Angola e Moçambique. Aliás, o José Eduardo dos Santos tinha relações muito estreitas com Pinto da Costa, e criticou-o de forma dura, considerando a decisão do MLSTP quase que uma traição ao grupo, por não ter ao menos avisado o que acabou por fazer. Sem dúvida, o Pinto da Costa ficou um bocado mal. O José Eduardo foi muito duro com ele. Mas, depois o José Eduardo teve também de fazer a sua abertura, mesmo que a contragosto. O movimento era imparável, e felizmente para Cabo Verde, fomos dos primeiros a perceber isso a par de São Tomé e Príncipe, é claro (VEIGA, 2014, p. 01).

A afirmação do ex-presidente cabo-verdiano evidencia que, apesar das relutâncias das elites políticas dos PALOP continentais, a abertura política e econômica após o fim da Guerra Fria mostrava-se inevitável. Conforme mencionado anteriormente, 
a pressão internacional para a democratização e implantação de uma economia capitalista foi intensa não somente nos PALOP, mas em praticamente todo o continente africano. Em Moçambique, as primeiras grandes transformações democratizantes foram efetivadas na revisão da sua Constituição Federal em 1990, período no qual a guerra civil encontrava-se na sua fase final, já ocorrendo as negociações de paz entre FRELIMO e RENAMO. Esse contexto histórico é relatado por Jafar (2014) da seguinte maneira:

\begin{abstract}
Com a intensificação da guerra nos meados e finais dos anos 80, a Renamo passou a controlar quase $80 \%$ do território moçambicano. As secas severas que afetaram terrivelmente o sul do país, a recessão económica, a crescente decadência da União Soviética e o corte de ajudas obrigou ao governo de Moçambique a aceitar as imposições neoliberais, em troca de ajuda externa ocidental, abandonando, assim, o sistema económico socialista de economia planificada para o sistema capitalista caracterizado pela economia orientada para o mercado, propriedade privada, envolvimento ativo do sector privado na economia (JAFAR, 2014, p. 20).
\end{abstract}

Taimo (2010) destaca os elementos que foram incorporados a esse novo cenário normativo do país, afirmando que:

\begin{abstract}
A Constituição de 1990 no seu preâmbulo resgata o papel histórico da FRELIMO como frente na conquista da Independência (não mais como partido dirigente). Proclama que as liberdades trazidas pela Independência são aprofundadas nesta Constituição, com a necessidade de se adequar à evolução da sociedade e do Mundo. É neste sentido que questões como luta contra o imperialismo e exploração de Homem pelo Homem já não fazem parte desta nova Carta Magna. No artigo seis (alíneas "d" e "e") aparecem termos muito caros ao liberalismo, ou seja, os direitos humanos, igualdade dos cidadãos perante a lei, democracia e liberdade individual. Esta declaração dos direitos fundamentais deixava de forma relativamente clara a viragem para o neoliberalismo do Estado moçambicano (TAIMO, 2010, p. 140).
\end{abstract}

No caso angolano, as primeiras mudanças constitucionais ocorreram em 1991, por meio de uma revisão parcial da sua Carta Magna (Lei 12/91). Joveta (2014) destaca que, entre os resultados, os princípios socialistas foram revogados, sendo substituídos por "uma nova ordem jurídica assente na democracia multipartidária, no princípio da legalidade, na garantia de direitos e liberdades fundamentais, no princípio da proporcionalidade e de meios menos lesivos" (JOVETA, 2014, p. 08). Assim como fora observado em Angola, a Constituição Federal da Guiné-Bissau também foi alterada no ano de 1991. Um dos principais aspectos dessa mudança pautou-se na retirada no artigo $4^{\text {o }}$ da Constituição de 1994, que pautava na concepção autocrática do PAIGC como a 
"força política dirigente da sociedade e expressão suprema da vontade soberana do povo, decidindo da orientação da política do Estado e assegurando a sua realização em estreita ligação às massas trabalhadores" (LOPES, 2010, p. 09). No âmbito do II Congresso Extraordinário do PAIGC, várias outras transformações normativas já tinham sido efetuadas, marcando o momento histórico no qual "o presidente Nino Vieira anunciou o início da democratização do país, tendo para o efeito sido alterada a Constituição, de modo a permitir o pluralismo político, a liberdade de expressão, associação, reunião e de imprensa" (SANGREMAN et al., 2006, p. 14). Lopes (2010) afirma que a liberalização guineense foi resultante de um conjunto de variáveis, tais como pressões externas e internas, em um cenário de grande crise econômica e instabilidade doméstica, a saber:

\begin{abstract}
Com a necessidade de fazer face à difícil situação económica por que passa o país e com a subida de nível de pressão interna e externa para a liberalização econômica e abertura multipartidária, o governo decidiu levar a cabo medidas de liberalização econômica, entre os quais a abolição de restrições ao comércio e a possibilidade de empresas privadas poderem fazer importação e exportação, outrora da competência exclusiva do governo. Essa imperatividade das mudanças políticas, económicas e sociais, que atingiu o continente africano desde o início da década de 90 chegava assim também a Guiné-Bissau (LOPES, 2010, p. 08).
\end{abstract}

Dessa forma, de acordo com a análise realizada, tem-se que todos os PALOP iniciaram o seu processo de liberalização política na década de 1990, conforme se observa na tabela a seguir. Destaca-se que essas liberalizações ocorreram de maneira negociada, sendo articuladas e implementadas pelos partidos políticos que estavam no poder durante o regime monopartidário, a saber: PAICV (Partido Africano da Independência de Cabo Verde) em Cabo Verde, MLSTP (Movimento para a Libertação de São Tomé e Príncipe) em São Tomé e Príncipe, FRELIMO (Frente de Libertação de Moçambique) em Moçambique, PAIGC (Partido Africano para a Independência da Guiné e Cabo Verde) em Guiné-Bissau e MPLA (Movimento Popular de Libertação de Angola ) em Angola. 
Tabela 45 - Análise da liberalização política dos PALOP após a década de 1990

\begin{tabular}{|l|l|l|l|l|l|}
\hline Variável/ País & $\begin{array}{l}\text { Cabo } \\
\text { Verde }\end{array}$ & $\begin{array}{l}\text { São Tomé e } \\
\text { Príncipe }\end{array}$ & Moçambique & $\begin{array}{l}\text { Guiné- } \\
\text { Bissau }\end{array}$ & Angola \\
\hline $\begin{array}{l}\text { Liberalização } \\
\text { política }\end{array}$ & $\mathrm{S}$ & $\mathrm{S}$ & $\mathrm{S}$ & $\mathrm{S}$ & $\mathrm{S}$ \\
\hline
\end{tabular}

Fonte: Tabela elaborada pela autora.

\section{2: Direitos políticos e liberdades civis durante a democratização}

No processo de democratização dos PALOP continentais, os direitos políticos foram mais evidentes do que as liberdades civis. Apesar desses avanços, esse universo ainda se apresenta muito limitado em países como Angola e Moçambique, no qual o mesmo partido governa desde a independência desses países. Mais grave ainda é a situação angolana, que possui o mesmo presidente, expresso na figura de José Eduardo dos Santos, no poder desde 1979.

De acordo com o gráfico que aborda o indicador relacionado às "eleições livres e justas" $" 58$, disponibilizado pela base de dados V-DEM, observa-se que os resultados dos PALOP insulares são expressivamente superiores aos dos PALOP continentais. Além disso, nota-se que o único país da África lusófona que teve um aumento do referido indicador antes de 1990 foi Cabo Verde. Uma das possíveis explicações para esse fenômeno pauta-se na conformação cultural e histórica cabo-verdiana, que se caracterizou como questionadora do autoritarismo desde o regime de partido único (KOUDAWO, 2001), conforme analisado no Capítulo 2 da presente tese.

\footnotetext{
${ }^{58} \mathrm{O}$ indicador sobre "Eleições livres e Justas" é denominado "Clear Elections" pelo V-DEM, que o define da seguinte maneira: "To what extent are elections free and fair? Clarifications: Free and fair connotes an absence of registration fraud, systematic irregularities, government intimidation of the opposition, vote buying, and election violence" (V-DEM, 2016). Já o "Índice de liberdades civis" é denominado "Liberal Democracy Index" pelo V-DEM, que o define da seguinte maneira: "To what extent is the ideal of liberal democracy achieved? Clarifications: The liberal principle of democracy emphasizes the importance of protecting individual and minority rights against the tyranny of the state and the tyranny of the majority. The liberal model takes a "negative" view of political power insofar as it judges the quality of democracy by the limits placed on government. This is achieved by constitutionally protected civil liberties, strong rule of law, an independent judiciary, and effective checks and balances that, together, limit the exercise of executive power. To make this a measure of liberal democracy, the index also takes the level of electoral democracy into account" (V-DEM, 2016).
} 
Gráfico 11 - Índice de eleições livres e justas dos PALOP (V-DEM, 2016)

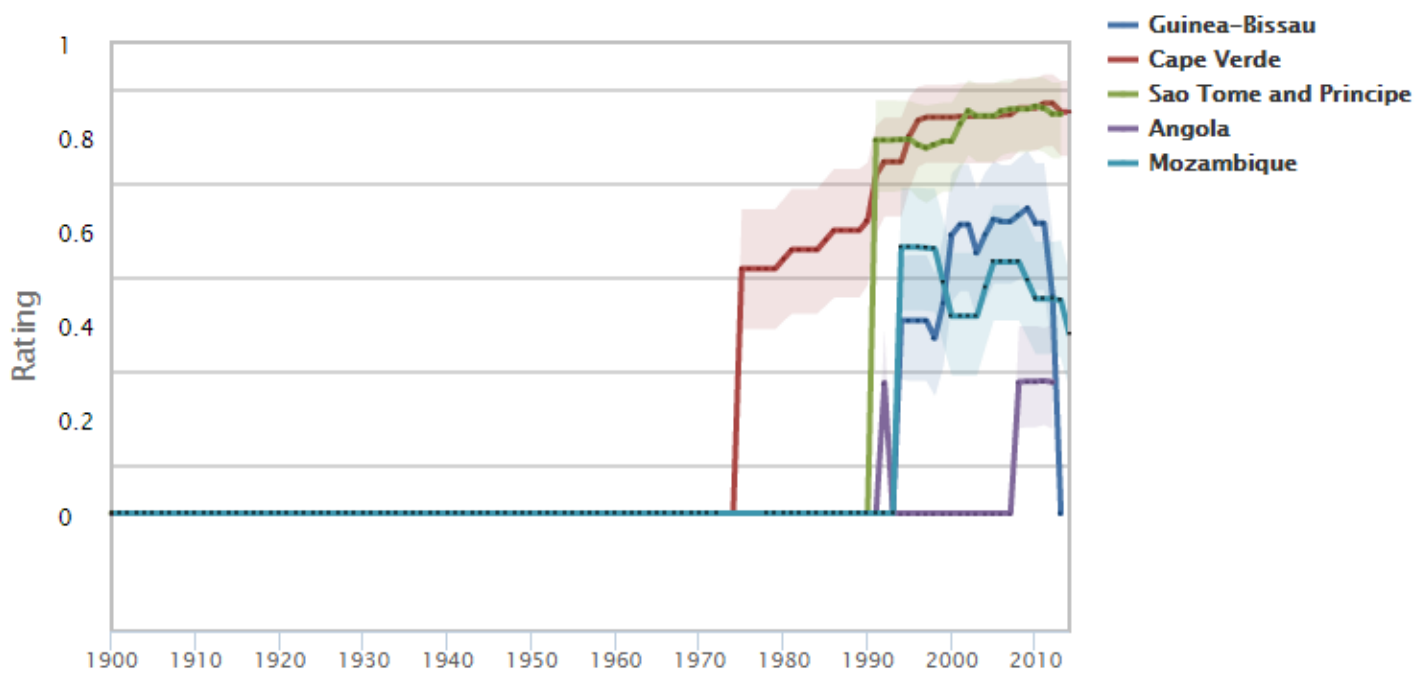

Fonte: V-DEM, 2016, s.p.

No âmbito das liberdades civis, os resultados dos PALOP insulares também se mostram maiores do que os seus pares continentais, conforme se observa no gráfico a seguir. Nesse cenário, ao contrário do que fora observado com a questão das eleições livres e justas, todos os PALOP apresentaram uma ascensão dos seus valores desde a década de 1970, a saber:

Gráfico 12 - Índice de liberdades civis dos PALOP (V-DEM, 2016)

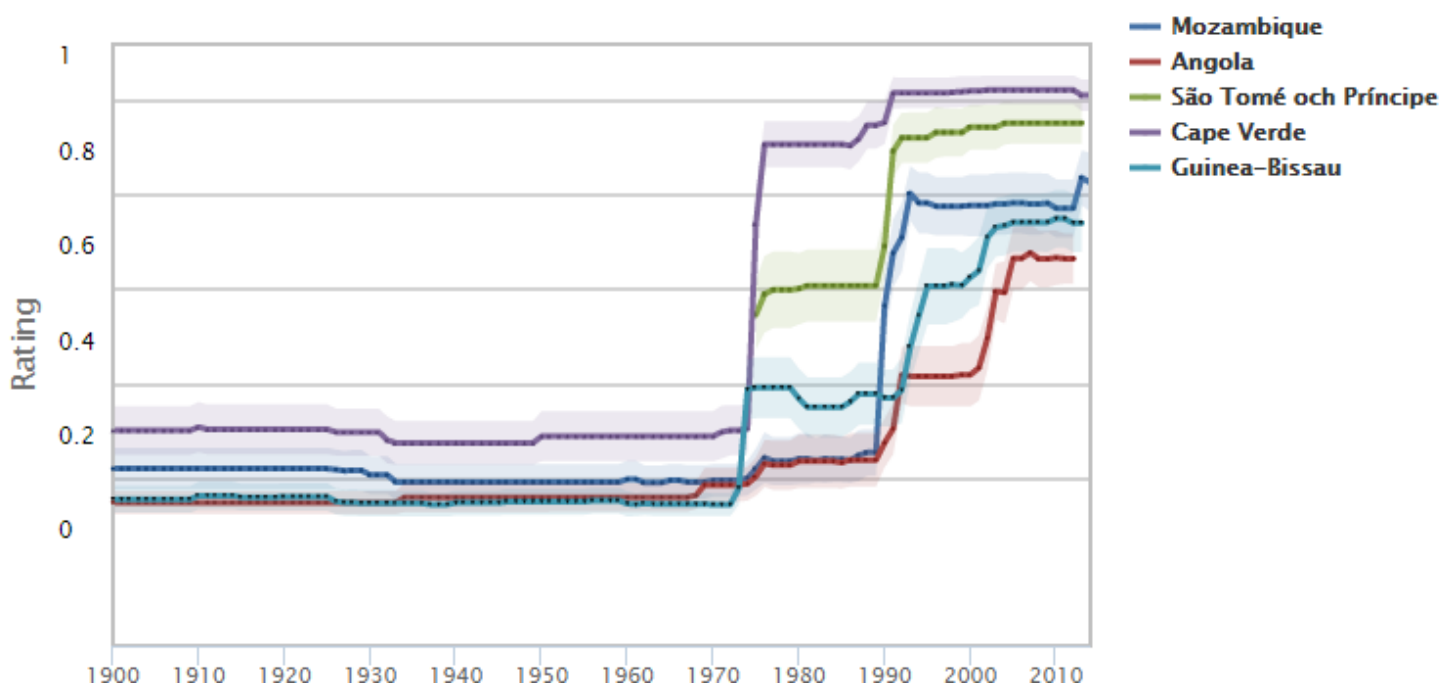

Fonte: V-DEM, 2016, s.p. 
Conforme exposto na revisão de literatura desta tese, é possível analisar a constituição dos direitos políticos e da liberdade civil dos PALOP no âmbito da liberalização política de acordo com os indicadores propostos por Schneider e Schmitter (2004). Nesse ínterim, os principais aspectos demonstrados pelos autores nesse momento democrático serão brevemente analisados à luz da realidade política e social de cada PALOP, a saber:

\section{a) O regime realiza concessões públicas significativas no nível dos direitos humanos:}

Os governos dos PALOP no início da década de 1990 realizaram importantes concessões públicas no nível dos direitos humanos. Essa postura mais democrática foi observada primeiramente por meio das supracitadas mudanças constitucionais que ocorreram no escopo normativo desses cinco países. Destarte, foram asseguradas diversas liberdades individuais e coletivas, tais como liberdade de expressão, manifestação, imprensa, entre outras. Na tabela a seguir, encontram-se os artigos de que abordam esse tópico no contexto da Constituição Federal de cada PALOP, a saber:

Tabela 46 - Liberdades civis nas Constituições Federais (CF) dos PALOP

\begin{tabular}{|c|c|c|c|c|c|}
\hline & $\begin{array}{c}\text { Liberdade } \\
\text { de } \\
\text { expressão }\end{array}$ & $\begin{array}{l}\text { Liberdade } \\
\text { de } \\
\text { informação }\end{array}$ & $\begin{array}{c}\text { Liberdade } \\
\text { de } \\
\text { imprensa }\end{array}$ & $\begin{array}{c}\text { Liberdade } \\
\text { de } \\
\text { Associação }\end{array}$ & $\begin{array}{l}\text { Liberdade de } \\
\text { reunião e } \\
\text { manifestação }\end{array}$ \\
\hline $\begin{array}{l}\text { Cabo Verde } \\
\text { (CF de } \\
1992)\end{array}$ & Art. $47^{\circ}$ & Art. $47^{\circ}$ & Art. $54^{\circ}$ & Art. $52^{\circ}$ & Art. $53^{\circ}$ \\
\hline $\begin{array}{l}\text { São Tomé e } \\
\text { Príncipe (CF } \\
\text { de 1990) }\end{array}$ & Art. $29^{\circ}$ & Art. $29^{\circ}$ & Art. $30^{\circ}$ & Art. $35^{\circ}$ & Art. $34^{\circ}$ \\
\hline $\begin{array}{l}\text { Moçambique } \\
\text { (CF de } 2004\end{array}$ & Art. $48^{\circ}$ & Art. $48^{\circ}$ & Art. $48^{\circ}$ & Art. $52^{\circ}$ & Art. $51^{\circ}$ \\
\hline $\begin{array}{l}\text { Guiné- } \\
\text { Bissau (CF } \\
\text { de 1996) }\end{array}$ & Art. $51^{\circ}$ & Art. $51^{\circ}$ & Art. $56^{\circ}$ & Art. $45^{\circ}$ & Art. $54^{\circ}$ \\
\hline $\begin{array}{l}\text { Angola (CF } \\
\text { de 2010) }\end{array}$ & Art. $40^{\circ}$ & Art. $40^{\circ}$ & Art. $44^{\circ}$ & Art. $48^{\circ}$ & Art. $47^{\circ}$ \\
\hline
\end{tabular}

Tabela elaborada pela autora utilizando as Constituições mais atualizadas de Cabo Verde, São Tomé e Príncipe, Moçambique, Guiné-Bissau e Angola (as referências específicas dessas Constituições encontramse na parte de documentação primária das referências bibliográficas da presente tese). 
Mesmo possuindo um aparato normativo robusto no que tange aos direitos e garantias fundamentais, nem todos os PALOP cumpriram e, atualmente, cumprem os pressupostos basilares da sua Carta Magna. Por serem democracias, os PALOP insulares respeitam a maior parte dessas regras, ao contrário dos seus pares continentais, que ainda se encontram em um processo de democratização lento e repleto de abusos de direitos e diversos tipos de censura. Em países com Angola, muitos direitos tais como o de manifestação, não podem ser vivenciados de maneira plena pelos seus cidadãos, fator gera prisões políticas e perseguições aos dissidentes.

a) O regime não tem (ou quase não tem) prisioneiros políticos e o regime demonstra crescente tolerância pela dissidência/ oposição pública de grupos sociais ou de organizações formais/ informais (por exemplo: partidos, associações ou movimentos)

\author{
O desespero fez com que me tornasse um kamikaze \\ agora sou persona non grata e amizade indesejada \\ Sou um kamikaze angolano e esta é a minha missão \\ não tenho tempo para repetição \\ não tenho tempo para refrão. \\ Luaty Beirão. Ikonoklasta.
}

No governo angolano, a tolerância por ideias dissidentes não apresentou muitos êxitos nos últimos 25 anos. Nesse contexto, Angola configura-se como o exemplo mais extremo dos PALOP no âmbito da realização de prisões políticas. Em 2012, entre outros casos, houve o desaparecimento de Alves Kamulingue e Issaías Cassule, ativistas que organizavam um protesto contra o governo. Recentemente, o episódio mais famoso ocorreu em 2015, no qual o país condenou por crime contra a segurança nacional 17 pessoas que estavam reunidas em uma residência lendo sobre democracia e desobediência pacífica (REVISTA FORUM, 2015). Entre eles, estava o “rapper” Luaty Beirão, famoso ativista que, durante a prisão, fez uma greve de fome de 36 dias contra o excesso de prisão preventiva. A sua atitude impulsionou uma campanha que se tornou internacionalmente conhecida contra a repressão do governo de Luanda. No final de 2016, ele lançou um diário de memórias retratando os seus 16 primeiros dias no cárcere, intitulado "Sou Eu Mais Livre, Então”. De forma mais discreta do que Angola, Guiné-Bissau é acusada por 
organizações independentes de também possuir prisioneiros políticos. Já em Moçambique, não há qualquer caso conhecido de presos políticos desde a democratização, sendo esse mesmo cenário nos PALOP insulares.

\section{b) Existe mais de um partido político independente legalmente reconhecido e existe pelo menos um partido de oposição reconhecido no Parlamento \\ ou na Assembleia Nacional}

Conforme foi mencionado, logo no início da democratização todos os PALOP realizaram mudanças constitucionais transformando o seu sistema político para um contexto pluripartidário, estabelecendo eleições periódicas. Nesse ínterim, conforme se observa na tabela abaixo, foram realizadas eleições as primeiras eleições presidenciais (founding elections) em 1991 em Cabo Verde e São Tomé e Príncipe, em 1992 em Angola e, finalmente, em 1994 em Guiné-Bissau e Moçambique. É importante destacar que, nos casos dos PALOP insulares houve alternância do partido político que se encontrava no poder, enquanto o mesmo partido continuou a governar as arenas políticas dos PALOP continentais. Na tabela a seguir, também será possível observar que a Constituição Federal de todos os PALOP garantiu direitos políticos mínimos, que foram cumpridos por todos eles, tais como sufrágio universal, liberdade de associação política/criação de partidos políticos e direito de oposição democrática dos partidos políticos, a saber:

Tabela 47 - Direitos políticos nas Constituições Federais (CF) dos PALOP

\begin{tabular}{|c|c|c|c|c|c|}
\hline & $\begin{array}{l}\text { Primeiras eleições } \\
\text { presidenciais } \\
\text { (diretas e } \\
\text { multipartidárias) }\end{array}$ & $\begin{array}{l}\text { Principais } \\
\text { partidos } \\
\text { políticos }\end{array}$ & $\begin{array}{l}\text { Sufrágio } \\
\text { universal }\end{array}$ & $\begin{array}{l}\text { Liberdade de } \\
\text { associação } \\
\text { política/ } \\
\text { criação de } \\
\text { partidos } \\
\text { políticos } \\
\end{array}$ & $\begin{array}{c}\text { Direito de } \\
\text { oposição } \\
\text { democrática } \\
\text { dos partidos } \\
\text { políticos }\end{array}$ \\
\hline $\begin{array}{l}\text { Cabo Verde } \\
\text { (CF de 1992) }\end{array}$ & 1991 & $\begin{array}{l}\text { PAICV e } \\
\text { MpD }\end{array}$ & Art. 104 & Art. 57 & Art. 118 \\
\hline $\begin{array}{l}\text { São Tomé e } \\
\text { Príncipe (CF } \\
\text { de 1990) }\end{array}$ & 1991 & $\begin{array}{l}\text { MLSTP- } \\
\text { PSD, } \\
\text { MDFM- } \\
\text { PL e ADI }\end{array}$ & Art. $6^{\circ}$ & Art. 63 & Art. 154 \\
\hline $\begin{array}{l}\text { Moçambique } \\
\text { (CF de 2004) }\end{array}$ & 1994 & $\begin{array}{l}\text { FRELIMO } \\
\mathrm{e} \\
\text { RENAMO }\end{array}$ & Art. 73 & Art. 53 & Art. 292 \\
\hline $\begin{array}{l}\text { Guiné-Bissau } \\
\text { (CF de 1996) }\end{array}$ & 1994 & $\begin{array}{l}\text { PAIGC e } \\
\text { PRS }\end{array}$ & Art. 130 & Art. $4^{\circ}$ & Art. 130 \\
\hline $\begin{array}{l}\text { Angola (CF de } \\
\text { 2010) }\end{array}$ & 1992 & $\begin{array}{l}\text { MPLA e } \\
\text { UNITA }\end{array}$ & Art. 54 & Art. 55 & Art. 17 \\
\hline
\end{tabular}

Tabela elaborada pela autora utilizando as Constituições mais atualizadas de Cabo Verde, São Tomé e Príncipe, Moçambique, Guiné-Bissau e Angola. 


\section{c) Existe uma imprensa independente e acesso a fontes alternativas de informação que são toleradas pelo governo}

Além de medir a liberdade no mundo, a Freedom House também mensura o grau de liberdade de imprensa nos diversos países do globo ${ }^{59}$. Em 2016, nenhum Estado africano continental foi considerado como "livre" no âmbito dessa variável, que é medida em uma escala de 0 a 100. Nesse contexto, destaca-se que somente três Estados, sendo eles insulares, foram classificados como "livres", a saber: Cabo Verde, São Tomé e Príncipe e Maurícia. Já Moçambique e Guiné-Bissau foram considerados pela instituição como parcialmente livres e, Angola, como "não-livre" (FREEDOM HOUSEc, 2017). É importante destacar que, no cenário moçambicano, o relatório sobre a liberdade do país em 2016 demonstrou uma queda em relação aos anos anteriores, sendo essa redução justificada por fatores como a intensificação de ataques à jornalistas e restrições aos meios de comunicação (FREEDOM HOUSEd, 2017).

De acordo com a análise realizada, é possível observar que, após a década de 1990, somente os PALOP insulares se tornaram amplamente livres, respeitando as normas constitucionais que abrangem tanto os direitos políticos quanto as liberdades civis. Em um contexto intermediário, encontra-se o caso moçambicano, que é seguido pelo guineense, e finalmente, pelo angolano (caracterizado como "não-livre"). Esses resultados podem ser observados na tabela abaixo, a saber:

Tabela 48 - Análise dos direitos políticos e liberdades civis dos PALOP após 1990

\begin{tabular}{|l|l|l|l|l|l|}
\hline Variável/ País & $\begin{array}{l}\text { Cabo } \\
\text { Verde }\end{array}$ & $\begin{array}{l}\text { São Tomé e } \\
\text { Príncipe }\end{array}$ & Moçambique & $\begin{array}{l}\text { Guiné- } \\
\text { Bissau }\end{array}$ & Angola \\
\hline $\begin{array}{l}\text { Direitos políticos } \\
\text { e liberdades civis } \\
\text { (t3) }\end{array}$ & $\mathrm{S}$ & $\mathrm{S}$ & $\mathrm{N}^{*}$ & $\mathrm{~N}$ & $\mathrm{~N}$ \\
\hline
\end{tabular}

Fonte: Tabela elaborada pela autora.

\footnotetext{
${ }^{59}$ Para medir a liberdade de imprensa, a Freedom House utiliza a mesma escala de 1 a 7 que aplica para
} medir a liberdade no mundo. 


\section{3: Crescimento econômico após 1990}

O crescimento econômico dos PALOP após 1990 esteve intimamente ligado ao recebimento de investimentos e doações externas. Nesse contexto, a única exceção pautase no caso de Angola, que teve o seu crescimento relacionado à significativa presença de recursos naturais no país, notadamente petróleo e diamantes. No caso dos PALOP insulares, o auxílio internacional serviu para fomentar o desenvolvimento em um cenário de recursos naturais limitados, por meio da diplomacia dos pequenos Estados. Já no âmbito dos PALOP continentais, notadamente em Moçambique e Angola, grande parte da ajuda externa foi direcionada para a reconstrução nacional nos seus cenários de pósguerra civil. É importante destacar que, na última década, o desempenho econômico de todos os PALOP apresentou uma significativa melhora, refletindo um cenário de maior estabilidade.

Em 1990, os maiores PIB per capita pertenciam aos PALOP insulares: enquanto o valor de Cabo Verde era de US\$1.233,45, o de São Tomé e Príncipe era US\$1.390,74 dólares. Em terceiro lugar, encontrava-se o PIB per capita de Moçambique, no valor US\$ 1.113,56. Em penúltimo lugar, encontrava-se Guiné-Bissau, com o total de US\$ 797,20, seguido por Angola, com US\$ 868,07 (V-DEM, 2016). Depois de 25 anos, todos os países apresentaram melhoras nesse indicador: o valor de Cabo Verde passou a ser, em 2016, de US\$6.700,00, enquanto o são tomense era de US\$3.300. Contudo, os maiores aumentos foram observados no cenário angolano, com um valor de US\$6.800. Nesse contexto, os piores valores encontram-se em Guiné-Bissau (US\$1.600) e em Moçambique (US\$1.200) (CIA, 2017), conforme se observa na tabela abaixo: 
Tabela 49 - PIB per capita (US\$) dos PALOP entre 1990 e 2016 (V-DEM, 2016 e

CIA, 2017)

\begin{tabular}{|l|l|l|l|l|l|l|}
\hline & $\mathbf{1 9 9 0}$ & $\mathbf{1 9 9 5}$ & $\mathbf{2 0 0 0}$ & $\mathbf{2 0 0 5}$ & $\mathbf{2 0 0 8}$ & $\mathbf{2 0 1 6}$ \\
\hline Cabo Verde & 1233,45 & 1319,27 & 1775,61 & 2203,72 & 2735,38 & 6.700 \\
\hline $\begin{array}{l}\text { São Tomé e } \\
\text { Príncipe }\end{array}$ & 1390,74 & 1284,30 & 1225,40 & 1364,58 & 1484,15 & 3.300 \\
\hline Moçambique & 1113,56 & 1085,21 & 1503,02 & 2057,93 & 2399,49 & 1.200 \\
\hline Guiné-Bissau & 868,07 & 811,73 & 680,29 & 613,79 & 616,69 & 1.600 \\
\hline Angola & 797,20 & 630,63 & 736,40 & 1034,86 & 1599,10 & 6.800 \\
\hline
\end{tabular}

*O V-DEM (2016) só possui dados sobre todos os PALOP até 2008. Dessa forma, os dados de 2016 foram obtidos no site da CIA (2017).

Tabela elaborada pela autora com dados do V-DEM (2016) e da CIA (2017).

Quanto ao crescimento percentual do PIB, tem-se que, nesse período, os PALOP insulares apresentaram as taxas mais estáveis que os seus pares continentais. Destaca-se que os maiores valores ocorreram em Angola, notadamente depois do fim da sua guerra civil, a saber:

Tabela 50 - Taxa percentual de crescimento do PIB dos PALOP entre 1990 e 2015 (V-DEM e BANCO MUNDIAL, 2016)

\begin{tabular}{|l|l|l|l|l|l|l|}
\hline & $\mathbf{1 9 9 0}$ & $\mathbf{1 9 9 5}$ & $\mathbf{2 0 0 0}$ & $\mathbf{2 0 0 5}$ & $\mathbf{2 0 0 8}$ & $\mathbf{2 0 1 5}$ \\
\hline Cabo Verde & 2,10 & 5,18 & 5,63 & 5,70 & 5,25 & 1,5 \\
\hline $\begin{array}{l}\text { São Tomé } \\
\text { Príncipe }\end{array}$ & $-0,11$ & $-1,30$ & $-0,05$ & 2,48 & 2,62 & 4,0 \\
\hline Moçambique & 0,00 & 11,31 & $-0,68$ & 6,06 & 4,49 & 6,6 \\
\hline Guiné-Bissau & 0,85 & 2,46 & 7,00 & 1,46 & 1,25 & 4,8 \\
\hline Angola & 1,71 & 16,43 & 0,37 & 16,90 & 10,63 & 3,0 \\
\hline
\end{tabular}

*O V-DEM só fornece dados para todos os PALOP até o ano de 2008. Dessa forma, os dados de 2015 foram obtidos por meio do Banco Mundial (2016).

Tabela elaborada pela autora com dados com V-DEM (2016) e do Banco Mundial (2016).

Conforme exposto no Capítulo anterior, as taxas de inflação constituem em um importante indicador que pode ser utilizado para analisar o desempenho econômico dos PALOP após o início da democratização. No caso cabo-verdiano, observa-se que as taxas inflacionárias se mantiveram estáveis durante todo o período analisado, principalmente 
entre 2005 e 2015, apresentando índices significativamente baixos. Esse resultado positivo evidencia o êxito das políticas econômicas adotadas pelo país após a sua democratização. Contudo, destaca-se que desde a década de 1980 (período do partido único), Cabo Verde apresenta bons resultados nesse aspecto específico. Já a situação econômica de São Tomé e Príncipe é historicamente mais instável do que a caboverdiana. Entretanto, quando comparado aos PALOP continentais, notadamente Angola, o país apresenta resultados relativamente bons, notadamente depois dos anos 2000, com a inflação abaixo de 17\% (FMI, 2017).

A Guiné-Bissau apresentou um quadro de oscilação da inflação um pouco pior do que o são tomense, refletindo também uma melhora dos seus resultados nos últimos 15 anos. O mesmo ocorreu em Moçambique, que chegou a 2015 com uma taxa de inflação de somente $2,4 \%$. Contudo, o país observou um significativo aumento de tal índice já no ano seguinte. Por sua vez, Angola caracteriza-se como o caso mais destoante entre todos os PALOP no âmbito da sua inflação, que chegou ao impressionante valor de $2.670 \%$ em 1995, no decorrer na sua guerra civil. No caso angolano, observa-se que, logo após o fim do conflito em 2002, os índices inflacionários reduziram-se significativamente, sendo que, em 2015, a inflação do país encontrava-se em 10,3\%. Assim como Moçambique, o país enfrenta uma crise econômica desde 2016, fazendo com que, nesse ano, o índice chegasse ao patamar de 33,7\% (FMI, 2017). Essas informações podem ser observadas na tabela abaixo:

Tabela 51 - Taxa de inflação dos PALOP de 1990 a 2015 - Porcentagem do Índice de Preços do Consumidor (FMI, 2017)

\begin{tabular}{|l|l|l|l|l|l|l|l|}
\hline & $\mathbf{1 9 9 0}$ & $\mathbf{1 9 9 5}$ & $\mathbf{2 0 0 0}$ & $\mathbf{2 0 0 5}$ & $\mathbf{2 0 1 0}$ & $\mathbf{2 0 1 5}$ & $\mathbf{2 0 1 6}$ \\
\hline Cabo Verde & 11,1 & 8,4 & $-2,4$ & 0,4 & 2,1 & 0,1 & 0,1 \\
\hline $\begin{array}{l}\text { São Tomé e } \\
\text { Príncipe }\end{array}$ & 42,2 & 36,8 & 11,0 & 17,2 & 13,3 & 5,3 & 3,9 \\
\hline $\begin{array}{l}\text { Guiné- } \\
\text { Bissau }\end{array}$ & 33,0 & 45,1 & 8,6 & 3,2 & 1,1 & 1,5 & 2,6 \\
\hline Moçambique & 43,7 & 47,7 & 12,7 & 6,4 & 12,7 & 2,4 & 16,7 \\
\hline Angola & 1,8 & 2.670 & 325 & 23 & 14,5 & 10,3 & 33,7 \\
\hline
\end{tabular}

Fonte: FMI, 2017, s.p.

De acordo com a análise realizada, tem-se que o período de 25 anos após a década de 1990 resultou no desenvolvimento econômico de todos os PALOP, 
principalmente considerando a gradativa reestruturação econômica de Angola e Moçambique depois das guerras civis. Todos os PALOP, notadamente os insulares, fundamentaram grande parte do seu crescimento na atração de ajuda internacional e de investimentos externos, fazendo dessa política uma forma de fomentar o crescimento nacional, que apresentou valores satisfatórios depois do início da sua democratização. Contudo, é preciso analisar esses dados com cautela tendo em vista que, historicamente, as economias cabo-verdiana e são tomense apresentavam um caráter de maior estabilidade quando comparadas às dos PALOP continentais, notadamente pela ausência de guerras civis nos seus territórios. Nesse cenário de crescimento econômico, é possível construir a seguinte tabela:

Tabela 52 - Análise do crescimento econômico dos PALOP após 1990

\begin{tabular}{|l|l|l|l|l|l|}
\hline Variável/ País & $\begin{array}{l}\text { Cabo } \\
\text { Verde }\end{array}$ & $\begin{array}{l}\text { São Tomé e } \\
\text { Príncipe }\end{array}$ & Moçambique & $\begin{array}{l}\text { Guiné- } \\
\text { Bissau }\end{array}$ & Angola \\
\hline $\begin{array}{l}\text { Crescimento } \\
\text { econômico (t3) }\end{array}$ & $\mathrm{S}$ & $\mathrm{S}$ & $\mathrm{S}$ & $\mathrm{S}$ & $\mathrm{S}$ \\
\hline
\end{tabular}

Fonte: Tabela elaborada pela autora.

\section{4: Desenvolvimento social após 1990}

Da mesma forma que o crescimento econômico apresentou resultados mais positivos em todos os PALOP depois da democratização, uma grande melhora foi observada em todos eles no âmbito do desenvolvimento social. Contudo, destaca-se que Cabo Verde e São Tomé e Príncipe obtiveram valores expressivos em diversos indicadores de educação e saúde, conforme será analisado a seguir. Como uma das explicações para esse sucesso, José Vicente Lopes (2015) afirma que:

\footnotetext{
$\mathrm{O}$ que permitiu que enquanto em outros países meios importantes fossem gastos para a guerra ou para a consolidação do Estado [...] aqui em Cabo Verde partes importantes desses recursos foram investidos na educação e na saúde, de tal forma que os 40 anos que hoje nós somos reflete em grande parte aquilo que nós conseguimos ser desde 1975 (VICENTE LOPES, 2015)
}

A perspectiva de que a não incidência de guerras pode fomentar o desenvolvimento social também é exposta por Saraiva (2008). Ao analisar as principais transformações da África no século XX, o autor destaca as externalidades negativas dos 
conflitos armados para a economia e sociedade dos países por eles afetados, afirmando que:

Os conflitos foram a mais importante causa imediata da pobreza no continente. A redução dramática dos mesmos faz pensar que os recursos, quase da ordem de US\$ 300 bilhões queimados nos conflitos entre 1990 e 2005, podem agora ser dirigidos às políticas de redução da pobreza e da miséria (SARAIVA, 2008, p. 89).

No âmbito dos PALOP, a expectativa de vida a partir de 1990 aumentou significativamente, sendo que esse fator pode ser correlacionado tanto com os benefícios advindos por meio da democratização nos países insulares quanto como um resultado do fim das guerras civis nos Estados continentais. Em 2012, o melhor resultado encontra-se no contexto de Cabo Verde, sendo o pior, na Guiné-Bissau -, destacando-se a notável a diferença entre ambos, que totaliza $23,7 \operatorname{anos}^{60}$. Dessa forma, observa-se que os PALOP continentais ainda apresentam valores significativamente reduzidos de expectativa de vida quando comparados a outros países no mundo.

Tabela 53 - Expectativa de vida dos PALOP entre 1990 e 2012 (V-DEM, 2016)

\begin{tabular}{|l|l|l|l|l|l|l|}
\hline & $\mathbf{1 9 9 0}$ & $\mathbf{1 9 9 5}$ & $\mathbf{2 0 0 0}$ & $\mathbf{2 0 0 5}$ & $\mathbf{2 0 1 0}$ & $\mathbf{2 0 1 2}$ \\
\hline Cabo Verde & 66,08 & 67,71 & 69,83 & 72,12 & 74,09 & 74,77 \\
\hline $\begin{array}{l}\text { São Tomé e } \\
\text { Príncipe }\end{array}$ & 61,81 & 62,60 & 63,34 & 64,64 & 65,93 & 66,21 \\
\hline Moçambique & 43,64 & 45,88 & 47,47 & 47,89 & 49,20 & 49,91 \\
\hline Guiné-Bissau & 49,09 & 50,58 & 51,47 & 52,40 & 53,58 & 54,05 \\
\hline Angola & 41,15 & 42,07 & 45,23 & 48,57 & 50,69 & 51,05 \\
\hline
\end{tabular}

*O V-DEM só possui resultados disponíveis dessa variável até 2012.

Fonte: Tabela elaborada pela autora com dados do V-DEM (2016).

Além da melhora da expectativa de vida, todos os PALOP apresentaram uma significativa redução da taxa de mortalidade infantil desde 1990. Entretanto, em 2012, somente Cabo Verde detinha valores considerados baixos, sendo que os índices são tomenses eram classificados como médios. Nesse contexto, todos os PALOP continentais

\footnotetext{
${ }^{60}$ Para fins de comparação, em 2012 a expectativa de vida do Brasil era de 73,67 anos, de 79,73 em Portugal, de 78,8 nos EUA, de 81,29 na Coreia do Sul, de 83,42 no Japão e de 56,27 na África do Sul (VDEM, 2016).
} 
permaneciam com valores altos, com Angola apresentando uma quantidade expressivamente superior à dos seus pares da África lusófona ${ }^{61}$.

Tabela 54 - Taxa de mortalidade infantil dos PALOP entre 1990 e 2012 (VDEM, 2016)

\begin{tabular}{|l|l|l|l|l|l|l|}
\hline & $\mathbf{1 9 9 0}$ & $\mathbf{1 9 9 5}$ & $\mathbf{2 0 0 0}$ & $\mathbf{2 0 0 5}$ & $\mathbf{2 0 1 0}$ & $\mathbf{2 0 1 2}$ \\
\hline Cabo Verde & 47,30 & 37,70 & 30,80 & 24,00 & 20,10 & 18,9 \\
\hline $\begin{array}{l}\text { São Tomé e } \\
\text { Príncipe }\end{array}$ & 66,60 & 63,60 & 56,80 & 47,30 & 40,10 & 38,0 \\
\hline Moçambique & 155,10 & 134,50 & 112,10 & 89,30 & 71,10 & 63,1 \\
\hline Guiné-Bissau & 122,40 & 112,90 & 105,30 & 95,30 & 85,20 & 80,8 \\
\hline Angola & 126,10 & 123,90 & 120,90 & 115,90 & 104,60 & 99,5 \\
\hline
\end{tabular}

*O V-DEM só possui resultados disponíveis dessa variável até 2012.

Fonte: Tabela elaborada pela autora com dados do V-DEM (2016).

Já no âmbito educacional, observou-se no período da democratização um expressivo aumento dos anos de escolaridade dos PALOP insulares, com uma pequena melhora desses valores nos seus pares continentais. O ano de 2015 marcou o momento no qual São Tomé e Príncipe alcançou o expressivo montante de 9,8 anos de estudo como média dos seus cidadãos com mais de 15 anos de idade. Destaca-se, ainda, que a diferença entre Cabo Verde e São Tomé e Príncipe com os demais países é muito grande. Como exemplo, tem-se que, em média, um cidadão são tomense estuda 7,63 anos a mais do que um guineense. Os números dos PALOP insulares são expressivos mesmo no contexto internacional, tendo em vista que, em 2015, o mesmo indicador revelou um valor de 7,96 para o Brasil, 7,46 para Portugal, 12,68 para o Japão, 11,72 para a Coreia do Sul e 13,48 para os Estados Unidos (V-DEM, 2016). Esse fenômeno evidencia a correlação entre democracia e escolaridade, tendo em vista que os PALOP com maior escolaridade constituem os mais democráticos do grupo, a saber:

${ }^{61}$ Para fins de comparação, em 2012 as taxas de mortalidade infantil eram de 12,9 no Brasil, 2,9 em Portugal, 6,0 nos EUA, 3,3 na Coreia do Sul, 2,2 no Japão e 33,3 na África do Sul (V-DEM, 2016). 
Tabela 55 - Quantidade de anos de escolaridade dos cidadãos com mais de 15 anos de idade nos PALOP entre 1990 e 2015 (V-DEM, 2016)

\begin{tabular}{|l|l|l|l|l|l|l|}
\hline & $\mathbf{1 9 9 0}$ & $\mathbf{1 9 9 5}$ & $\mathbf{2 0 0 0}$ & $\mathbf{2 0 0 5}$ & $\mathbf{2 0 1 0}$ & $\mathbf{2 0 1 5}$ \\
\hline Cabo Verde & 3,85 & 4,82 & 6,0 & 7,00 & 7,39 & 7,54 \\
\hline $\begin{array}{l}\text { São Tomé e } \\
\text { Príncipe }\end{array}$ & 4,75 & 4,99 & 5,18 & 4,94 & 7,54 & 9,80 \\
\hline Moçambique & 1,95 & 2,13 & 2,30 & 2,32 & 2,35 & 2,36 \\
\hline Guiné-Bissau & 1,53 & 1,78 & 1,98 & 1,90 & 2,67 & 2,17 \\
\hline Angola & 1,84 & 2,06 & 2,28 & 2,53 & 2,79 & 2,89 \\
\hline
\end{tabular}

Fonte: Tabela elaborada pela autora com dados do V-DEM (2016).

É possível utilizar o IDH como indicador de desenvolvimento social somente no momento histórico que abarca democratização dos PALOP, tendo em vista que só existem dados disponibilizados para Cabo Verde e Guiné-Bissau a partir da década de 2000. Conforme se observa no gráfico abaixo, apesar do aumento do IDH de todos os PALOP no referido período, Cabo Verde e São Tomé e Príncipe apresentam os melhores resultados, seguidos por Angola, Guiné-Bissau e Moçambique, a saber:

\section{Gráfico 13 - IDH dos PALOP de 1980 a 2014 (PNUD)}

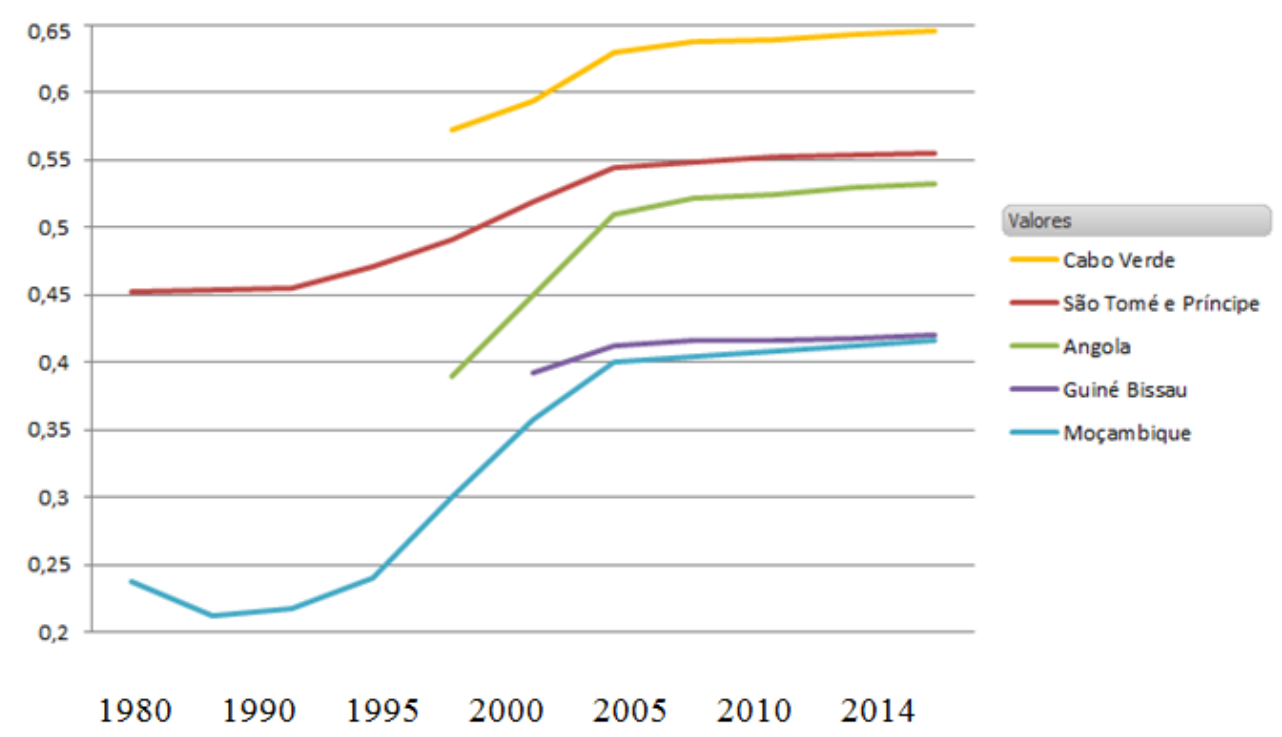

Fonte: Gráfico elaborado pela autora com dados do PNUD (2017). 
De acordo com a análise realizada, tem-se que após o início da democratização, todos os PALOP obtiveram melhoras nos seus resultados relacionados ao desenvolvimento social. Contudo, ao contrário do que ocorreu com o crescimento econômico, as melhoras sociais dos PALOP continentais foram relativamente menores. Esse dado sugere que, em Angola e Moçambique, a democratização fomentou um crescimento econômico que não se traduziu em significativas melhoras sociais. Já a democratização em Guiné-Bissau além de não trazer um expressivo crescimento econômico, também não exprimiu ganhos sociais. Nos PALOP insulares, a situação mostrou-se completamente diferente: o sucesso da democratização propiciou um relativo crescimento econômico que foi acompanhado por um relativo desenvolvimento social. Em síntese, esses fenômenos permitem a criação da seguinte tabela:

Tabela 56 - Análise do desenvolvimento social (relativo) dos PALOP após 1990

\begin{tabular}{|l|l|l|l|l|l|}
\hline Variável/ País & $\begin{array}{l}\text { Cabo } \\
\text { Verde }\end{array}$ & $\begin{array}{l}\text { São Tomé e } \\
\text { Príncipe }\end{array}$ & Moçambique & $\begin{array}{l}\text { Guiné- } \\
\text { Bissau }\end{array}$ & Angola \\
\hline $\begin{array}{l}\text { Desenvolvimento } \\
\text { social }(\mathrm{t} 3)\end{array}$ & $\mathrm{S}$ & $\mathrm{S}$ & $\mathrm{N}$ & $\mathrm{N}$ & $\mathrm{N}$ \\
\hline
\end{tabular}

Fonte: Tabela elaborada pela autora.

\section{VII5: Criação de instituições democráticas fortes}

Inglehart e Welzel (2009) mencionam o quão complexo e difícil é o processo de criação de instituições fortes em uma democracia, afirmando que "it is unrealistic to assume that democratic institutions can be set up easily, almost anywhere, at any time" (INGLEHART; WELZEL, 2009, s.p.). Nesse contexto, Kpundeh (1992) destaca que, em linhas gerais, o modelo colonial de administração autocrática no continente africano teve como consequência a fragilidade na criação de instituições democráticas no pósindependência.

No escopo da presente tese, essa variável é importante para explicar tanto o êxito de democratização dos PALOP insulares quanto o seu (relativo) insucesso nos PALOP continentais no pós-Guerra Fria. Dessa forma, quatro indicadores foram escolhidos para realizar essa análise, a saber: a) voice and accountability (WORLDWIDE GOVERNANCE INDICATOR); b) controle da corrupção (WORLDWIDE 
GOVERNANCE INDICATOR); c) qualidade da administração pública (WORLDWIDE GOVERNANCE INDICATOR) e d) índice Ibrahim de governança (ÍNDICE IBRAHIM DE GOVERNANÇA NA ÁFRICA).

O indicador voice and accountability é definido pelo Banco Mundial da seguinte maneira: "Voice and accountability captures perceptions of the extent to which a country's citizens are able to participate in selecting their government, as well as freedom of expression, freedom of association, and a free media" (WORLDWIDE GOVERNANCE INDICATOR, 2017, s.p.). De 2005 a 2015, Cabo Verde permaneceu com a melhor classificação entre os PALOP, seguido por São Tomé e Príncipe, Moçambique, GuinéBissau e, finalmente, Angola. É interessante destacar que, nesse período, somente Moçambique a Guiné-Bissau apresentaram uma diminuição nos valores desse índice, conforme se observada na tabela a seguir:

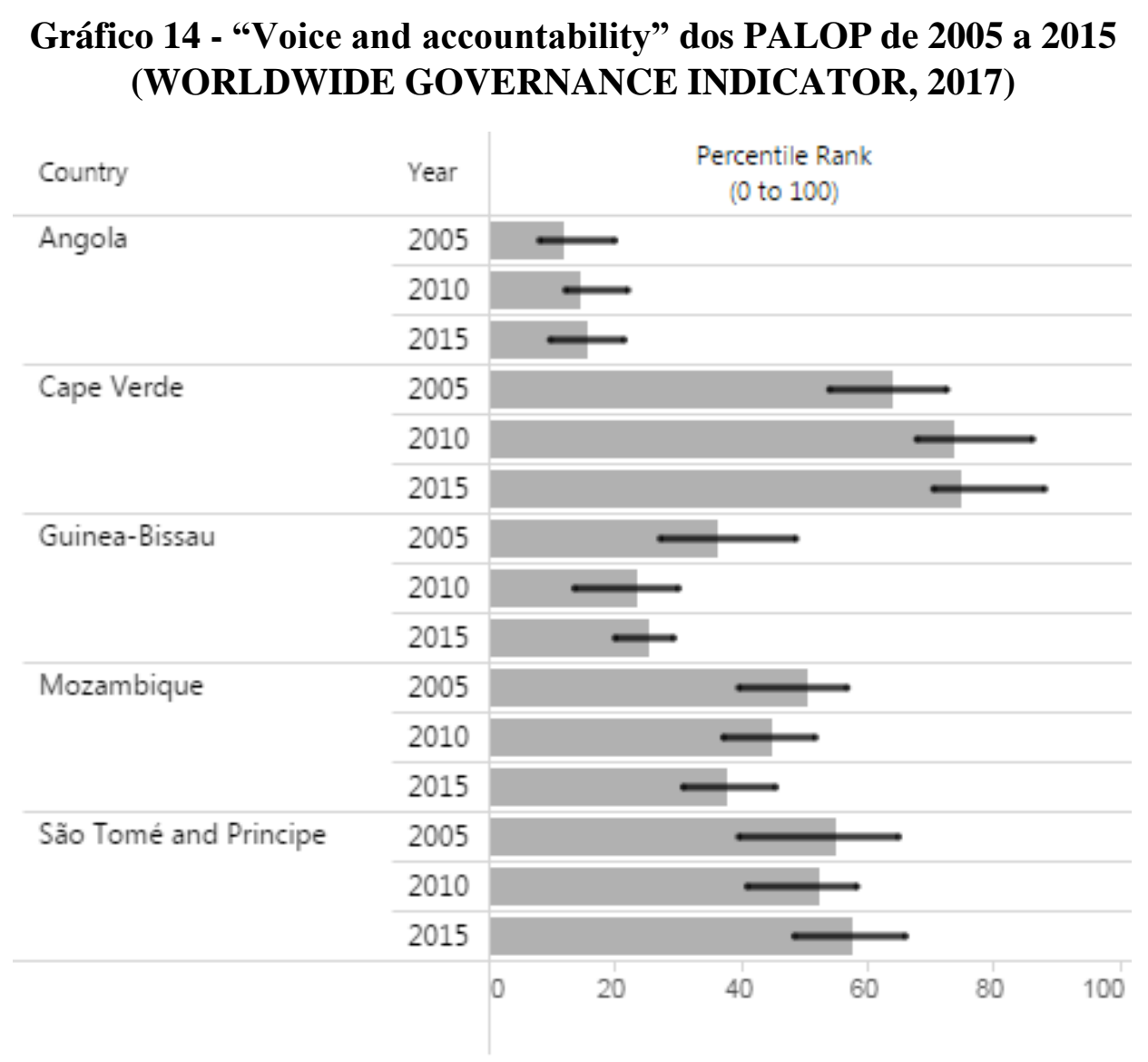

Fonte: WORLDWIDE GOVERNANCE INDICATORS, 2017, s.p. 
O indicador referente ao controle da corrupção nos PALOP também foi mensurado pelo Worldwide Governance Indicators no período de 2005 a 2015. Esse índice específico é definido pela instituição como:

Control of corruption captures perceptions of the extent to which public power is exercised for private gain, including both petty and grand forms of corruption, as well as "capture" of the state by elites and private interests. This table lists the individual variables from each data sources used to construct this measure in the Worldwide Governance Indicators (WORLDWIDE GOVERNANCE INDICATOR, 2017, s.p.).

Mais uma vez, Cabo Verde manteve-se isoladamente como detentor dos melhores valores desse índice, seguido por São Tomé e Príncipe e Moçambique. Em penúltimo lugar, encontram-se Guiné-Bissau e Angola, destacando-se que entre 2005 e 2010, os valores guineenses eram melhores do que os angolanos, a saber:

\section{Gráfico 15 - Controle da Corrupção nos PALOP 2005 a 2015 (WORLDWIDE GOVERNANCE INDICATOR, 2017)}

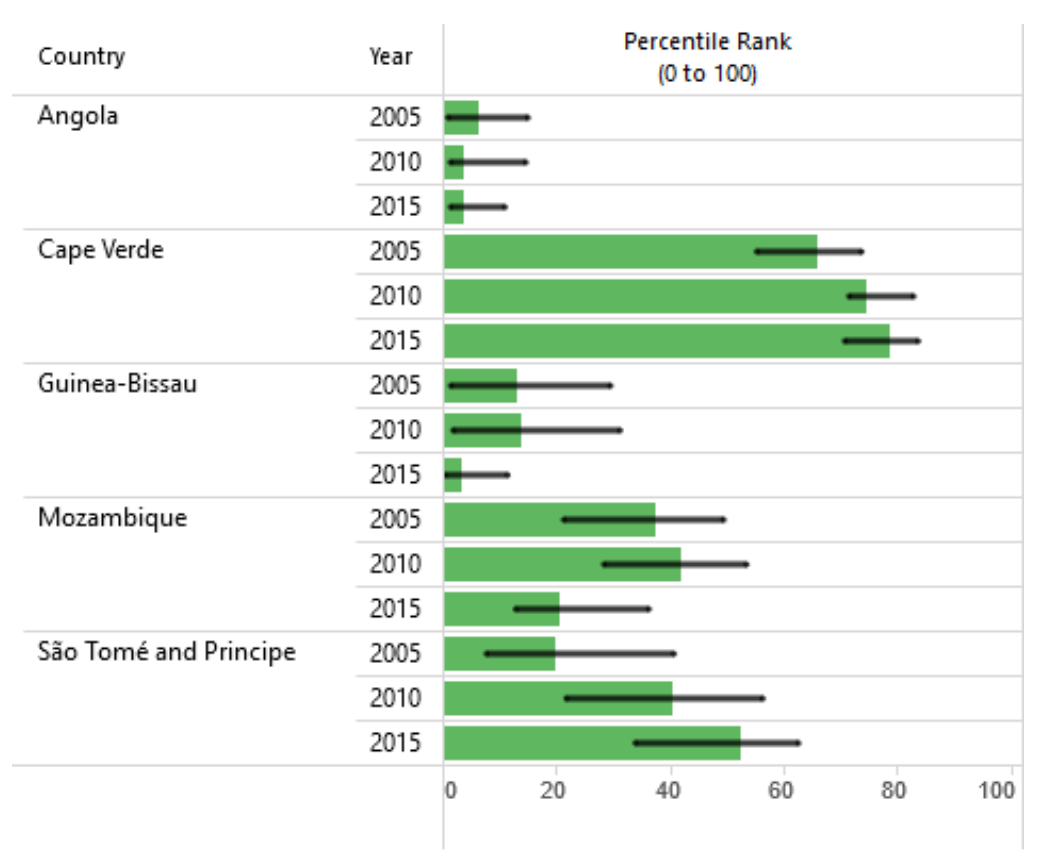

Fonte: WORLDWIDE GOVERNANCE INDICATORS, 2017, s.p.

O terceiro indicador da Worldwide Governance que foi utilizado para analisar a qualidade das instituições democráticas dos PALOP refere-se à efetividade do governo, sendo esse índice caracterizado da seguinte maneira: 
Government effectiveness captures perceptions of the quality of public services, the quality of the civil service and the degree of its independence from political pressures, the quality of policy formulation and implementation, and the credibility of the government's commitment to such policies. This table lists the individual variables from each data sources used to construct this measure in the Worldwide Governance Indicators (WORLDWIDE GOVERNANCE INDICATOR, 2017, s.p.).

Conforme se observa no gráfico a seguir, tem-se mais uma vez a liderança cabo verdiana no universo dos PALOP. Em segundo lugar, empatados com a mesma pontuação em 2015, encontram-se Moçambique e São Tomé e Príncipe. Esse indicador é interessante porque denota que, em determinados aspectos, as instituições democráticas moçambicanas apresentaram muitos avanços desde 2005, sendo esse um fator que ajuda a explicar o caráter intermediário da sua democracia. Vale ressaltar que em 2005 e 2010, o país apresentou resultados ainda melhores do que os são tomenses. Em penúltimo lugar, tem-se Angola, seguida por Guiné-Bissau, que detém valores muito reduzidos quando comparados aos outros países analisados, a saber:

\section{Gráfico 16 - Efetividade do governo nos PALOP (WORLDWIDE GOVERNANCE INDICATOR, 2017)}

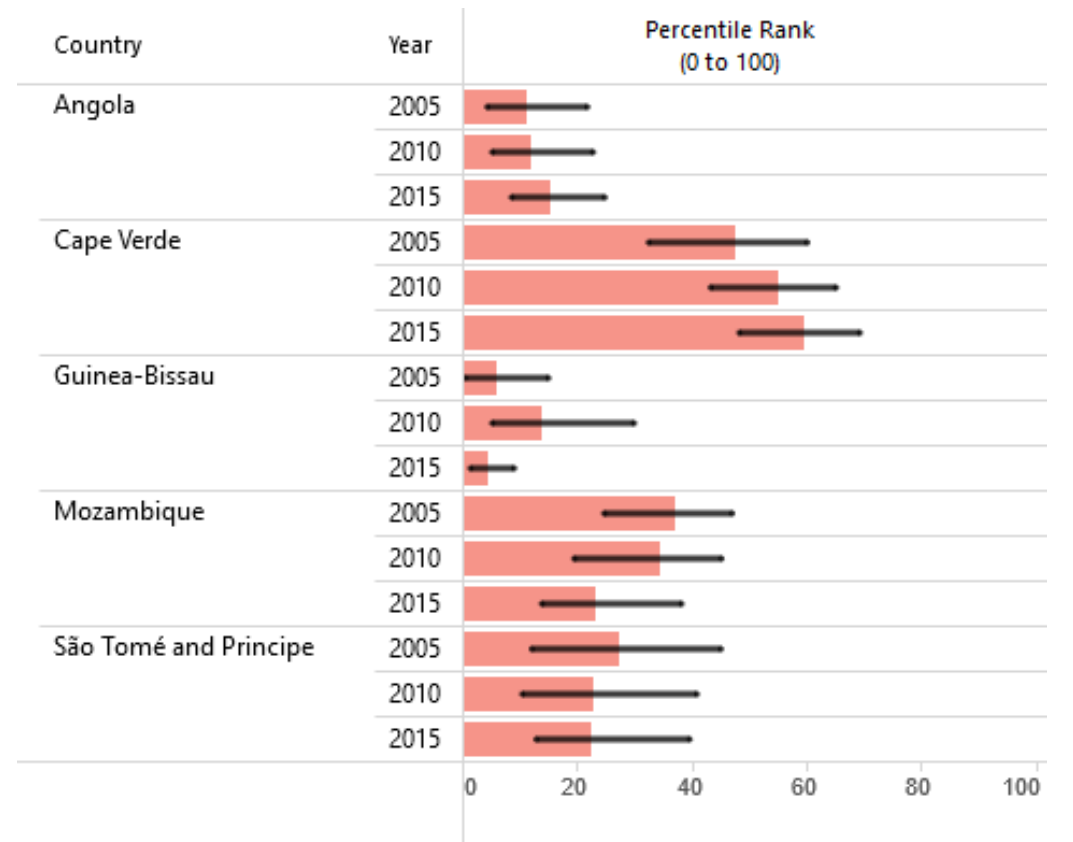

Fonte: WORLDWIDE GOVERNANCE INDICATORS, 2017, s.p.

Finalmente, o último indicador selecionado para a análise desta variável referese ao Índice Ibrahim de Governança na África, que é descrito pela instituição da seguinte maneira: 
Governance is defined by the Mo Ibrahim Foundation as the provision of the political, social and economic public goods and services that every citizen has the right to expect from his or her state, and that a state has the responsibility to deliver to its citizens. This definition is focused on outputs and outcomes of policy. The IIAG governance framework comprises four categories:

1. Safety \& Rule of Law

2. Participation \& Human Rights

3. Sustainable Economic Opportunity, and

4. Human Development (ÍNDICE IBRAHIM DE GOVERNANÇA NA ÁFRICA, 2016, s.p.).

No âmbito dos PALOP, o melhor resultado é, mais uma vez, ocupado por Cabo Verde, que possui mais de 70 pontos (de um total de 100 pontos). Em segundo lugar, temse São Tomé e Príncipe, com aproximadamente 60 pontos. O terceiro lugar é ocupado por Moçambique, que tem como resultado somente alguns pontos acima da média africana (50 pontos). Por fim, encontrando-se quase 10 pontos abaixo do valor continental, estão Guiné-Bissau e Angola, que apresentam valores muito semelhantes no ano de 2015 (ÍNDICE IBRAHIM DE GOVERNANÇA NA ÁFRICA, 2016). Esses dados encontram-se presentes no seguinte gráfico:

\section{Gráfico 17 - Governança nos PALOP (ÍNDICE IBRAHIM DE GOVERNANÇA NA ÁFRICA, 2016)*}

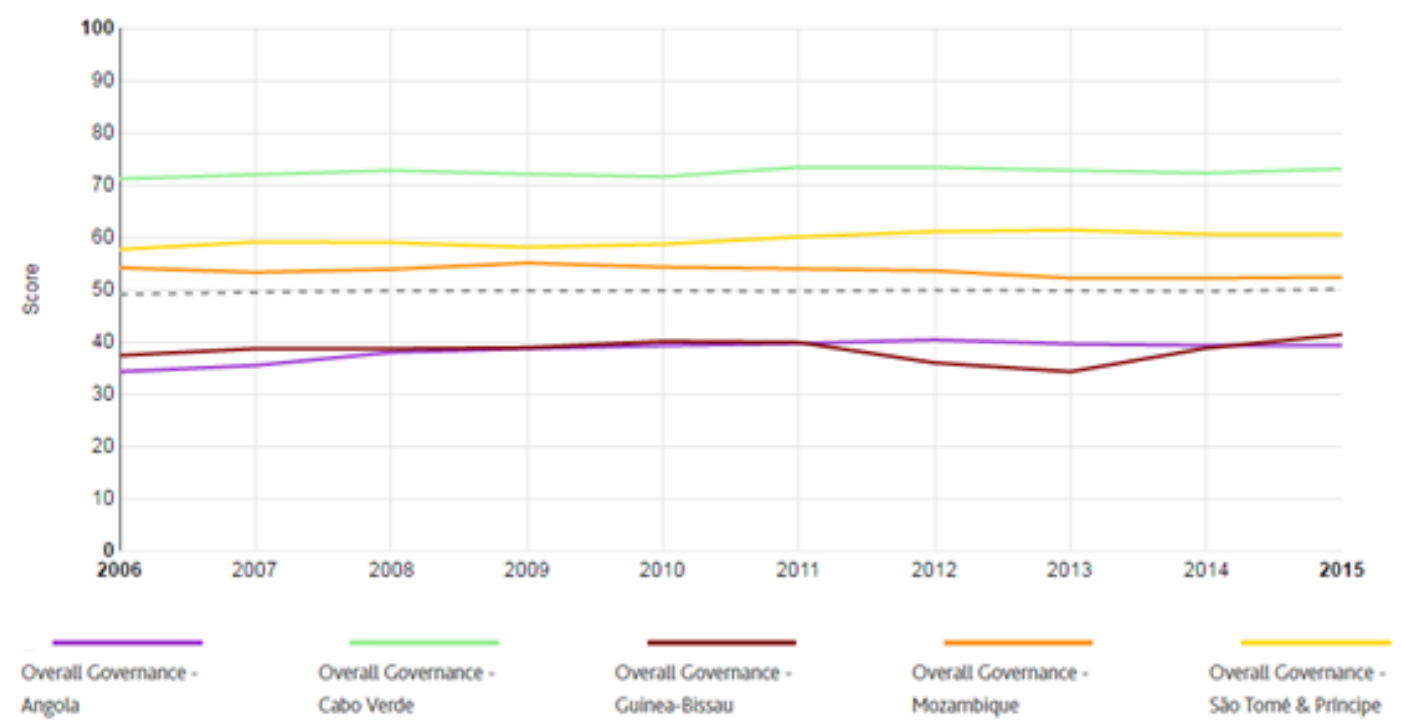

*É importante destacar que o valor " 50 ” representa a média da governança na África de acordo com o indicador.

Fonte: IBRAHIM INDEX OF AFRICAN GOVERNANCE (IIAG), 2017, s.p. 
De acordo com a análise realizada, observa-se que a criação de instituições democráticas em Cabo Verde e São Tomé e Príncipe mostrou-se muito mais avançada e exitosa quando comparada ao universo dos PALOP continentais. Contudo, Moçambique evidenciou resultados relativamente bons nesse aspecto, fator que ajuda a explicar a classificação atual do país como "parcialmente livre" pela Freedom House (2016). Dessa forma, é possível expressar esses fenômenos por meio da seguinte tabela:

\section{Tabela 57 - Análise da criação de instituições democráticas fortes dos PALOP}

\begin{tabular}{|l|l|l|l|l|l|}
\hline Variável/ País & $\begin{array}{l}\text { Cabo } \\
\text { Verde }\end{array}$ & $\begin{array}{l}\text { São Tomé e } \\
\text { Príncipe }\end{array}$ & Moçambique & $\begin{array}{l}\text { Guiné- } \\
\text { Bissau }\end{array}$ & Angola \\
\hline $\begin{array}{l}\text { Criação de } \\
\text { instituições } \\
\text { democráticas fortes }\end{array}$ & $\mathrm{S}$ & $\mathrm{S}$ & $\mathrm{N}^{*}$ & $\mathrm{~N}$ & $\mathrm{~N}$ \\
\hline
\end{tabular}

Fonte: Tabela elaborada pela autora.

\section{6: Alternância efetiva de poder partidário ${ }^{62}$}

A alternância efetiva de poder constitui um dos principais aspectos que explicam o êxito de uma transição democrática, conforme explicitado na Capítulo 1 da presente tese. Para analisar os resultados dessa variável no universo dos PALOP, é necessário compreender a trajetória política de cada país desde as suas founding elections. Dessa forma, a cena doméstica desses Estados será analisada à luz dos seus resultados eleitorais, considerando como alternância de poder a transição de partido político na esfera presidencial. Ao se caracterizar a alternância de poder partidário como efetiva, supõe-se que o presidente eleito pôde exercer todo o seu mandato, não sofrendo quaisquer impedimentos. Como exemplo, tem-se que na Guiné-Bissau, a única alternância de poder partidário ocorreu nas eleições de 1999 com a vitória de Kumba Ialá, do PRS. Contudo, ele sofreu um golpe de Estado quase três anos depois de ter sido eleito, encontrando-se impossibilitado de completar seu governo. Dessa forma, para fins analíticos do impacto da transição de poder para a democratização, tem-se no âmbito desta tese que a breve alternância de poder na Guiné-Bissau não foi efetiva.

\footnotetext{
${ }^{62}$ Informações detalhadas sobre a trajetória eleitoral (legislativa e presidencial) de todos os PALOP desde as primeiras eleições legislativas no período partido único até 2017 encontram-se no Anexo E.
} 
Outro aspecto que será brevemente analisado no escopo dessa variável se refere ao perfil civil e militar das lideranças políticas dos PALOP. Nesse contexto específico, Soderberg e Ohlson (2003) afirmam que esse assunto pode ser interpretado da seguinte maneira:

\begin{abstract}
Several authors have pointed out that the coercive strength of the military constitutes one of the greatest threats to democratization in weak states. As one of the most important aspects of democratization is the subordination of the military under civilian and democratic control, the military establishment is often the institution that stands to lose most from a transition to democratic policies, while also controlling the means available to reverse the transition process (SODERBERG; OHLSON, 2002, p. 37).
\end{abstract}

Em Cabo Verde, as primeiras eleições presidenciais ocorreram em 1991. Como resultado, houve a derrota do PAICV (Partido Africano da Independência de Cabo Verde), que concorria com Aristides Pereira, e a vitória de António Mascarenhas Monteiro, do MpD (Movimento para a Democracia), que constitui o maior partido de oposição do país. Isso significa que, logo nas primeiras eleições, que foram classificadas como livres e justas, Cabo Verde perpassou uma alternância de poder pacífica e efetiva. Em 1996, Mascarenhas Monteiro foi reeleito como único candidato, sendo apoiado tanto pelo PAICV quanto pelo MpD. Já em 2001 e 2006, houve uma nova alternância de poder, com o regresso do PAICV à cena política na figura de Pedro Pires (AFRICAN ELECTIONS, 2016). Nesse cenário, é importante mencionar que no segundo turno das eleições de 2001 Pires ganhou com uma diferença de apenas 12 votos. Por sua vez, nas eleições de 2011 e 2016, novamente o poder retornou ao MpD com as vitórias eleitorais de Jorge Carlos Fonseca. Dessa forma, observa-se que, na cena cabo-verdiana, desde o início da democratização a alternância efetiva de poder partidário esteve presente. No referido contexto, a esfera militar não detinha grande interferência na administração nacional, havendo um controle dos civis sobre as Forças Armadas. Destaca-se, também, que o país não vivenciou quaisquer golpes de Estado durante toda a sua existência, fator que resultou em grande estabilidade política durante a sua democratização. Em síntese, tem-se no gráfico abaixo a trajetória eleitoral do Poder Executivo de Cabo Verde desde 1991, a saber: 


\section{Gráfico 18 - Eleições Presidenciais em Cabo Verde (AFRICAN ELECTIONS, 2016)}

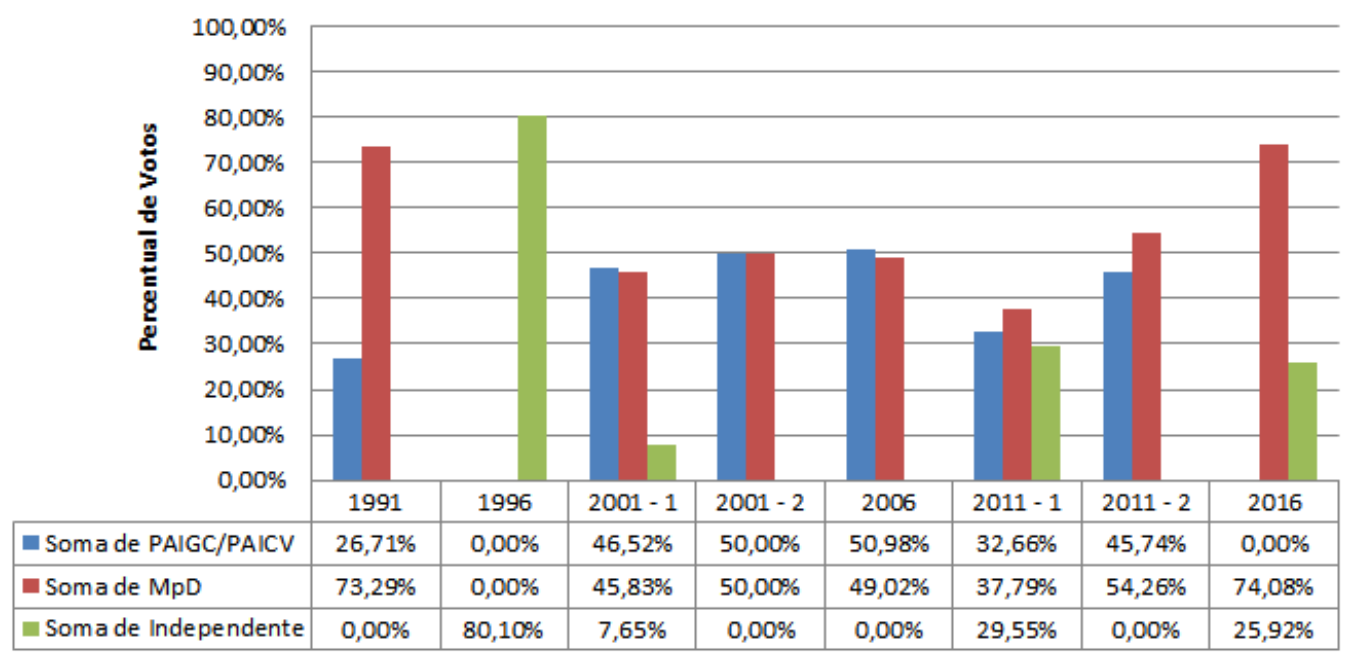

Fonte: Gráfico elaborado pela autora com dados do African Elections (2016).

O resultado das primeiras eleições legislativas do país em 1991 também se mostra fundamental para explicar o êxito do seu processo democrático. Koudawo (2001) afirma que a vitória do MpD com 61,41\% dos votos para a Assembleia Nacional nesse ano fez com que as mudanças constitucionais em prol da democracia fossem estabelecidas de maneira rápida e consistente, a saber:

Com mais de dois terços dos assentos no parlamento, o MpD dispunha de uma maioria qualificada que lhe permitia modificar à vontade a Constituição, intenção que manifestara antes das eleições. Apoiado nesta relação de forças favorável, o MpD implementa uma vasta gama de reformas destinadas a concretizar a Mudança. A celeridade e a envergadura das transformações conferem à Mudança as características de uma fuga em frente que modifica substancialmente as regras do jogo democrático, afeta profundamente os setores-chave tanto à escala nacional como local, e edifica as condições de uma hegemonia que se alimenta a si própria (KOUDAWO, 2001, p.81).

Assim como ocorrera em Cabo Verde, em São Tomé e Príncipe as eleições de 1991 também evidenciaram um cenário de alternância de poder tanto na Assembleia Nacional, com 54,4\% dos votos para o Partido Convergência Democrática - Grupo Reflexão (PCD-GR), quanto no Poder Executivo, com a vitória de Miguel Trovoada como candidato independente. De maneira semelhante ao exposto na cena cabo-verdiana, a arena política são tomense no pós-Guerra Fria também propiciou a eficaz 
implementação de um conjunto de reformas democratizantes no país. No pleito de 1996, Miguel Trovoada se reelegeu, candidatando-se nesse momento pela Ação Democrática Independente (ADI), considerada o maior partido político de oposição ao Movimento para a Libertação de São Tomé e Príncipe (MLSTP). Nas eleições de 2001, A ADI venceu novamente, na figura de Fradique de Menezes. Já nas eleições seguintes, Menezes se reelegeu com a legenda de outro partido político: o MDFM-PL (Movimento Democrático Força da Mudança - Partido Liberal). Já em 2011, Manuel Pinto da Costa foi eleito como candidato independente, voltando ao poder depois de 10 anos, tendo em vista que ele foi presidente do país durante todo o período de partido único. Em 2016, a alternância de poder se fez presente mais uma vez na estrutura política são tomense com a vitória de Evaristo Carvalho, candidato pela ADI (AFRICAN ELECTIONS, 2016).

Além das transições de poder que ocorreram no país de maneira pacífica, observa-se também que a elite política são tomense não apresentou como característica uma forte fidelidade partidária. Destaca-se, nesse ínterim, que o MLSTP-PSD (o PSD, que significa Partido Social Democrata, foi acrescentado após 1990) não elegeu qualquer presidente desde o início da democratização, mesmo tendo significativas votações no âmbito legislativo (Assembleia Nacional). Outro aspecto importante da política do país situa-se no significativo controle dos civis sobre os militares, assim como ocorre em Cabo Verde. As informações (até 2011) sobre a trajetória eleitoral do Poder Executivo de São Tomé e Príncipe podem ser observadas no seguinte gráfico:

\section{Gráfico 19 - Eleições Presidenciais em São Tomé e Príncipe (AFRICAN ELECTIONS, 2016)}

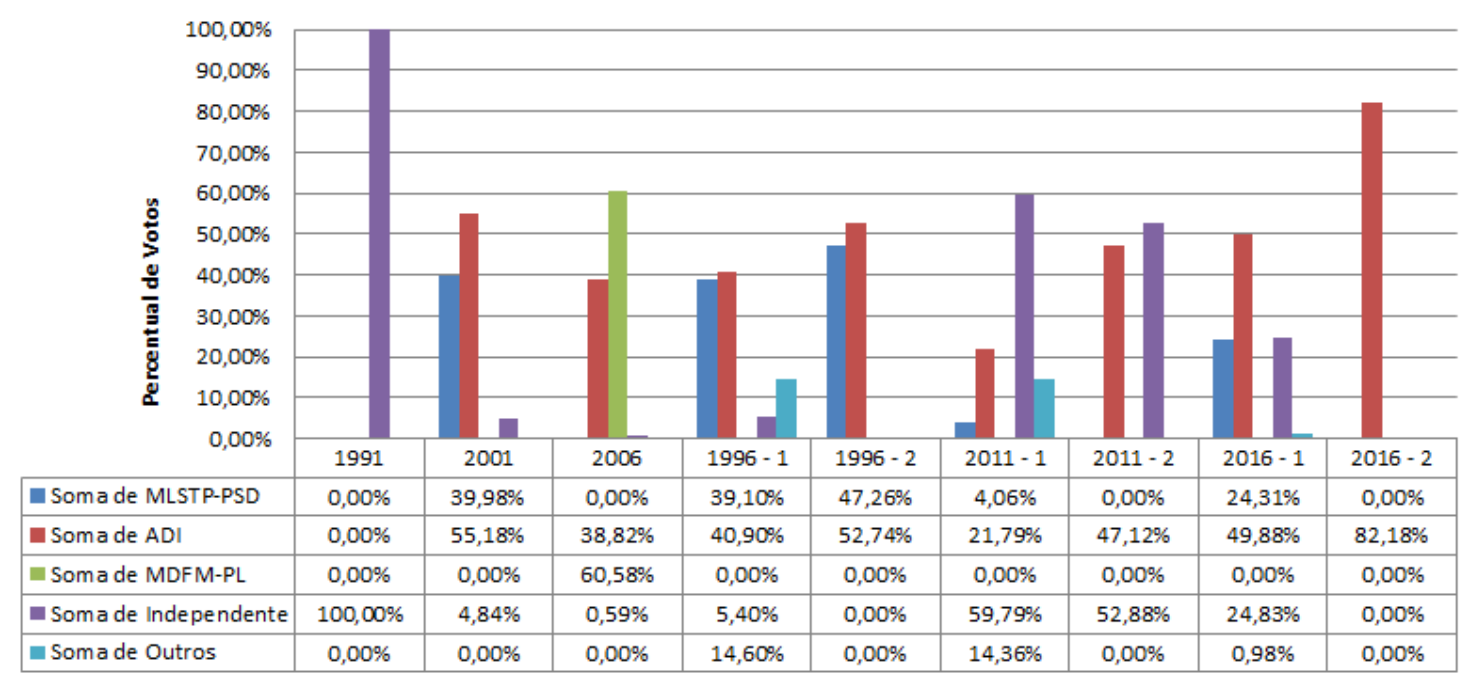

Fonte: Gráfico elaborado pela autora com dados do African Elections (2016). 
No processo de democratização de Moçambique, além das eleições presidenciais de 1994, ocorreram outros quatro pleitos para o Poder Executivo, sendo eles em 1999, 2004, 2009 e 2014. Em todas essas disputas eleitorais, a FRELIMO foi vitoriosa (com Joaquim Chissano em 1994 e 1999, Armando Guebuza em 2004 e 2009 e Filipe Nyusi em 2014), fator que impediu a alternância de poder partidário na trajetória política nacional. Além disso, o país iniciou a sua transição democrática em um cenário de grande instabilidade após a guerra civil, fazendo com que mudanças significativas a favor da democracia acontecessem de maneira um pouco mais cautelosa e lenta. Destaca-se que, no âmbito de todas eleições legislativas, que ocorreram em 1994, 1999, 2004, 2009 e 2014, a FRELIMO também conseguiu a maioria dos assentos. Nesse contexto, a trajetória política do Poder Executivo moçambicano pode ser observada no gráfico a seguir:

\section{Gráfico 20 - Eleições Presidenciais em Moçambique (AFRICAN ELECTIONS, 2016)}

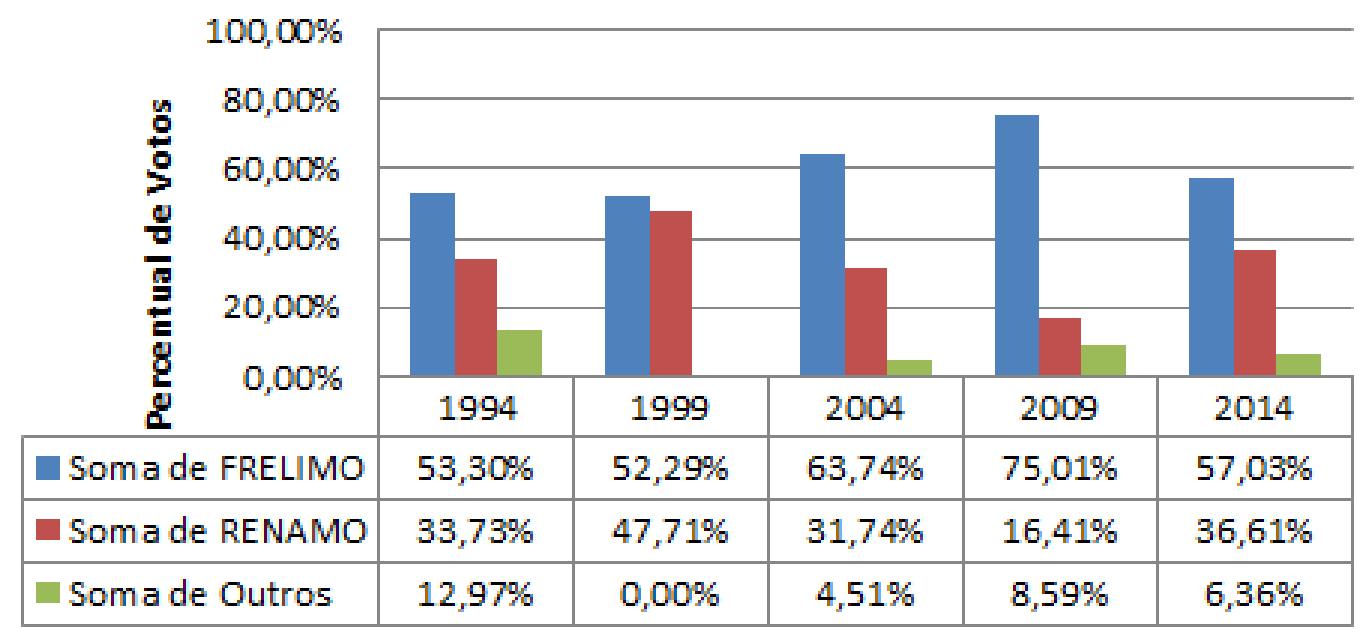

Fonte: Gráfico elaborado pela autora com dados do African Elections (2016).

Nesse ínterim, é importante ressaltar que a influência política das Forças Armadas em Moçambique não se apresenta expressiva, havendo o controle dos civis sobre os militares. Durante o seminário "Relações Civis-Militares em Moçambique: Passado, Presente e Futuro", que ocorreu em 2015 na cidade de Maputo, o acadêmico José Magode contextualiza o debate sobre esse tema no país da seguinte maneira:

José Magode referiu que esse seminário poderá permitir a produção de subsídios para a compreensão da causalidade da persistência, sob pretexto de Estado de Direito em Moçambique, de um dualismo na abordagem das 
relações civis-militares: por um lado, o poder púbico constitucionalmente legitimado a pugnar pela consolidação da ordem constitucional das instituições democráticas e, por outro, a contracorrente política a pugnar pela desconstrução da fronteira entre o Estado e as Forças Armadas, propondo uma relação de parceria e não a subordinação entre estas e o Estado. "Num contexto democrático, a adoção de uma Constituição liberal impõe a exigência da subordinação das Forças Armadas ao poder político, tornando-se aquelas um instrumento para o exercício legal da força. Por conseguinte, as Forças Armadas não devem se envolver em questões políticas" (JORNAL NOTÍCIAS, 2015, s.p.).

Assim como ocorreu no contexto moçambicano, na Guiné-Bissau as primeiras eleições presidenciais ocorreram em 1994. No pleito, ao contrário da expectativa de grande parte da população, não ocorreu a alternância de poder em função da vitória de Nino Vieira, do PAIGC, com 52\% dos votos, contra Kumba Ialá, do Partido da Renovação Social (PRS). Em 1998/1999, período no qual a democratização encontravase no seu início, o país esteve imerso em um cenário de grande instabilidade, permeado por um golpe de Estado seguido por uma guerra civil. Após o fim do conflito, ocorreram eleições presidenciais em 1999, marcando a primeira alternância de poder do país com a vitória de Kumba Ialá (PRS). Contudo, de acordo o explicitado anteriormente, Ialá sofreu um golpe de Estado em 2003 e não pôde terminar o seu mandato. Já em 2005, Nino Viera voltou ao poder como candidato independente, com uma vitória no segundo turno totalizando 52,35\% dos votos. Em 2009 e em 2012, foram vitoriosos, respectivamente os candidatos Bacai Sanhá e Carlos Jr., ambos do PAIGC. Finalmente, nas eleições de 2014, José Mário Vaz tornou-se presidente, também pelo PAIGC. Conforme se observa no gráfico abaixo, a arena política guineense foi primordialmente um espaço de atuação do PAIGC, tendo como exceção a eleição de Kumba Ialá em 1999, em um cenário no qual a alternância de poder não se concretizou de maneira efetiva. Essas informações podem ser observadas no gráfico abaixo: 


\section{Gráfico 21 - Eleições Presidenciais em Guiné-Bissau (AFRICAN ELECTIONS,} 2016)

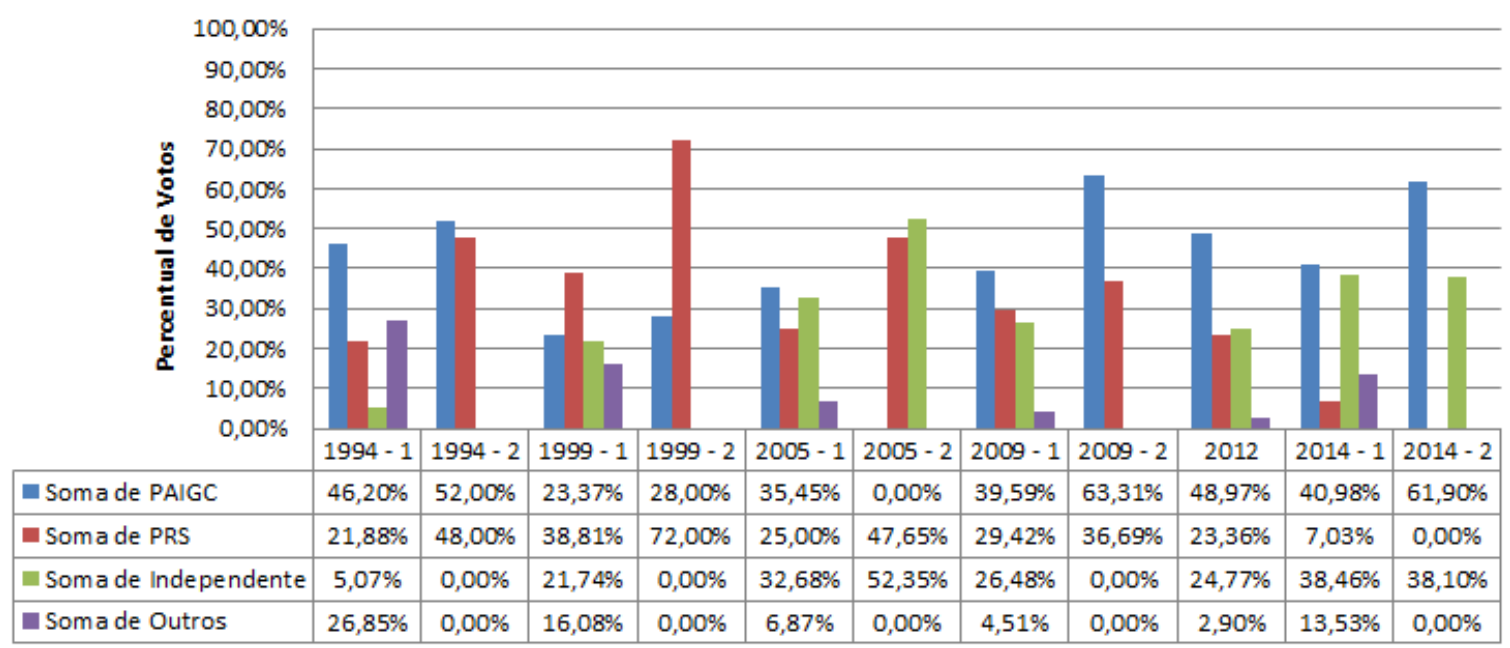

Fonte: Gráfico elaborado pela autora com dados do African Elections (2016).

No âmbito legislativo, a alternância de poder guineense ocorreu apenas em 1999, com o PRS detendo a maioria dos assentos parlamentares. Além disso, as Forças Armadas exercem grande influência na administração do Estado, sendo elas compostas majoritariamente por uma única etnia, os balantas (TVZIMBO, 2009, s/p). Como exemplo, tem-se que, após a sua volta do exílio, "Nino nunca voltou a ser um presidente aglutinador, a sua governação foi sempre minada pelos militares, desejosos em controlar os destinos do país" (TV ZIMBO, 2009, s.p.).

Por fim, tem-se o caso angolano como o mais extremo no conjunto dos PALOP: o país realizou somente uma eleição presidencial direta, no ano de 1992, em um período breve de paz no contexto da guerra civil. Como resultado, o pleito conferiu 49,57\% dos votos para o Movimento Popular de Libertação de Angola (MPLA), 40,07\% para a União Nacional para a Independência Total de Angola (UNITA) e 10,36\% para outros partidos (AFRICAN ELECTIONS, 2016). A não aceitação do resultado eleitoral por parte da UNITA fez com que o conflito fosse retomado e se prologasse por mais 10 anos, ingressando na sua fase mais violenta, conforme exposto no Capítulo anterior. Nesse ínterim, desde 1979, José Eduardo dos Santos ocupa interruptamente o cargo de presidente do país. Isso se explica porque, de acordo com o artigo $109^{\circ}$ da Constituição da República Angolana de 2010, "é eleito Presidente da República e Chefe do Executivo o cabeça de lista, pelo círculo nacional, do partido político ou coligação de partidos políticos mais votado no quadro das eleições gerais" (CONSTITUIÇÃO DA 
REPÚBLICA DE ANGOLA, 2010). Essa conformação política é criticada por muitos autores, conforme se observa na afirmação de Bessa (2014), a saber:

Miranda adverte que o sistema de governo angolano, não sendo evidentemente, um sistema parlamentar, tão pouco se ajustaria ao modelo presidencial. Aliás, Miranda é crítico, afirmando que os poderes e modo de eleição do Presidente da República violam o princípio da separação de poderes e o sufrágio direto e universal dos órgãos políticos, propendendo a Constituição da República Angolana para uma espécie de bonapartismo. De acordo com Jorge Miranda, a característica determinante no contraste com o presidencialismo no atual sistema angolano é o sistema eleitoral, que garante a eleição simultânea tanto dos deputados quanto para o Presidente da República (arts. $109^{\circ}$, e $143^{\circ}$ ); o que elimina a independência dos dois poderes (o Executivo e o Legislativo) (BESSA, 2014, p. 65).

Nesse contexto, em 2008 e 2012 o MPLA venceu a UNITA de maneira expressiva, perpetuando o cenário de governação de José Eduardo dos Santos há 38 anos. Dessa maneira, a falta de alternância de poder não somente partidário, mas também individual, bem como a frágil independência dos Poderes refletem um aspecto importante do caráter autocrático de Angola. Já no âmbito do controle dos civis sobre os militares, observa-se que a influência das Forças Armadas no cenário político do país é relativamente pequena, mostrando-se muito distinta da realidade guineense, onde foram impetrados diversos golpes militares. Em síntese, o gráfico com os resultados das eleições legislativas no país pode ser observado abaixo:

\section{Gráfico 22 - Eleições Legislativas em Angola (AFRICAN ELECTIONS, 2016)}

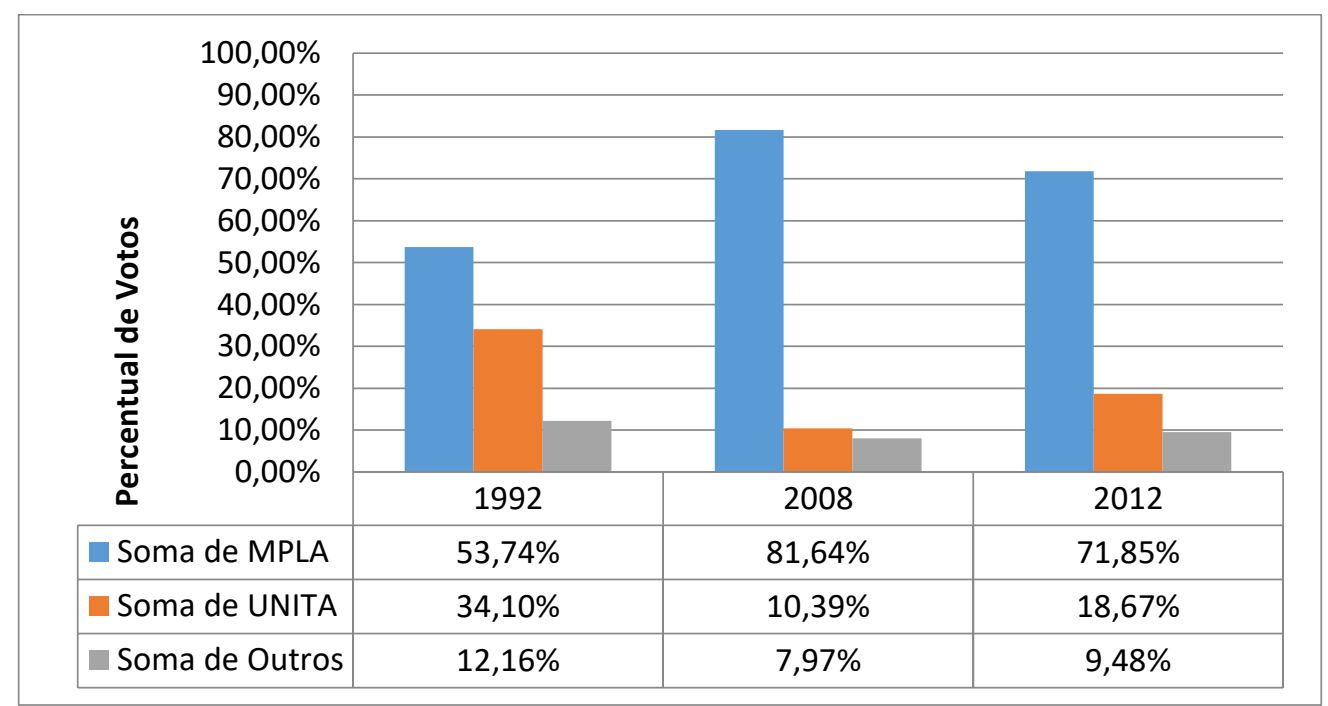

Fonte: Gráfico elaborado pela autora com dados do African Elections (2016). 
De acordo com a análise realizada, tem-se a alternância efetiva de poder partidário ocorreu somente nos casos dos PALOP insulares, fator que ajuda a explicar o sucesso das suas transições democráticas. Destarte, esses resultados podem ser observados na tabela a seguir:

Tabela 58 - Análise da alternância efetiva de poder partidário nos PALOP

\begin{tabular}{|l|l|l|l|l|l|}
\hline Variável/ País & $\begin{array}{l}\text { Cabo } \\
\text { Verde }\end{array}$ & $\begin{array}{l}\text { São Tomé e } \\
\text { Príncipe }\end{array}$ & Moçambique & $\begin{array}{l}\text { Guiné- } \\
\text { Bissau }\end{array}$ & Angola \\
\hline $\begin{array}{l}\text { Alternância de } \\
\text { poder e controle } \\
\text { dos civis sobre os } \\
\text { militares }\end{array}$ & $\mathrm{S}$ & $\mathrm{S}$ & $\mathrm{N}$ & $\mathrm{N}$ & $\mathrm{N}$ \\
\hline
\end{tabular}

Fonte: Tabela elaborada pela autora.

\section{Período histórico: 25 anos depois do início da democratização (2015)}

\section{VD: Democracia liberal}

Vinte e cinco anos depois do início da democratização, a trajetória democrática de cada PALOP se apresenta única, refletindo um estágio próprio de avanços e retrocessos. Conforme exposto ao longo da presente tese, enquanto Cabo Verde se apresenta como o PALOP mais democrático, Angola se encontra no extremo oposto. Os diferentes aspectos domésticos e externos que refletiram nesses resultados foram analisados de maneira longitudinal no decorrer desse estudo, evidenciando similaridades e diferenças no percurso formativo desses Estados da África lusófona.

Neste estudo, a democracia liberal foi medida considerando os seguintes indicadores: Freedom House, Polity IV e V-DEM. A análise da Freedom House ocorreu na Introdução dessa tese, o Polity IV, no escopo do Capítulo 2 e, finalmente, o V-DEM mensurou os ganhos democráticos dos PALOP no tópico relacionado aos direitos políticos e liberdades civis deste Capítulo. A seguir, a trajetória democrática da África lusófona será brevemente analisada à luz do Polity IV (para os casos da Cabo Verde, Moçambique, Guiné-Bissau e Angola) e da Freedom House (para o caso de São Tomé e Príncipe), apresentando a evolução democrática desses países desde a década de 1970 (no âmbito do Polity IV). 
Com o fim da Guerra Fria, Cabo Verde iniciou um processo de democratização expressivo, alcançando e mantendo a mais elevada pontuação possível de democracia do Polity IV (+10) a partir de 2002, sendo classificado pelo índice como uma "democracia completa”. O gráfico exposto a seguir também evidencia que o país não vivenciou golpes de Estado ou guerras civis na sua história, a saber:

\section{Gráfico 23- Trajetória democrática de Cabo Verde de 1975 a 2013 (POLITY IV, 2016a)}

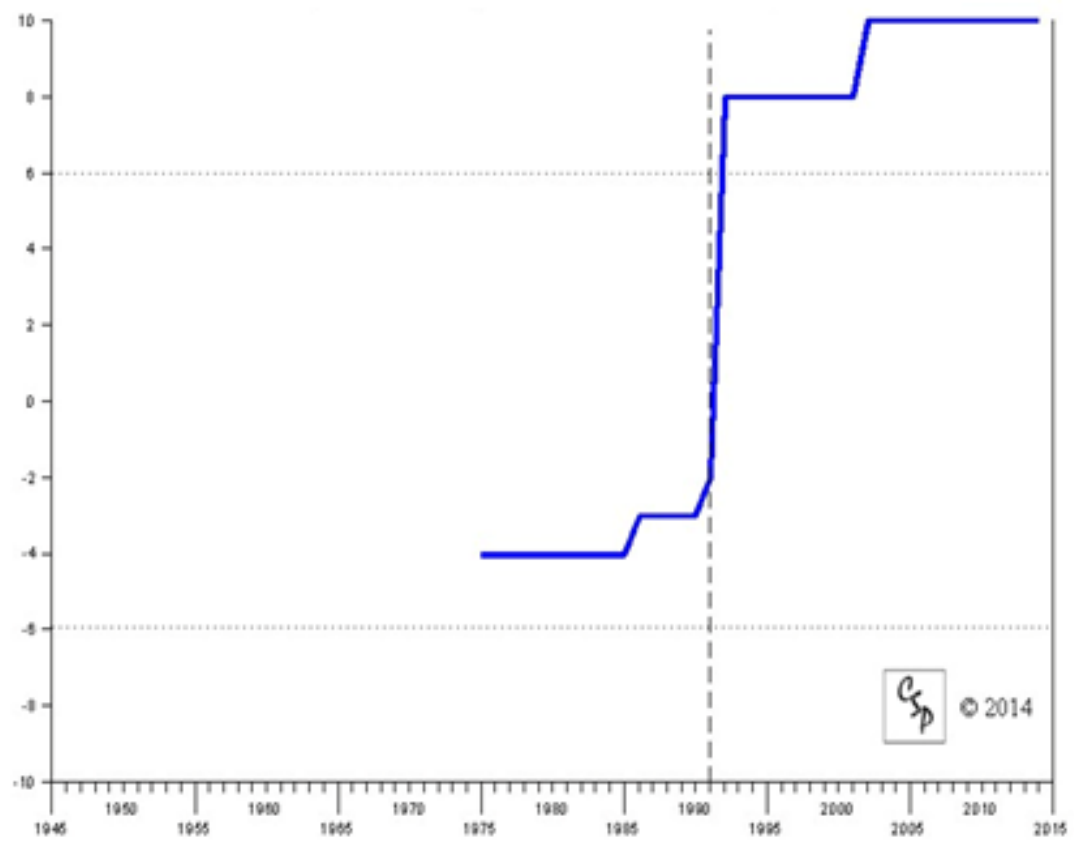

Fonte. POLITY IV, 2016a, s.p.

Apesar do gráfico de São Tomé e Príncipe não se encontrar disponibilizado pelo Polity IV, com base nos dados da Freedom House (2017) é possível observar que o país apresenta um cenário semelhante ao cabo-verdiano, constituindo-se em uma democracia, mas com uma pontuação um pouco menor.

Já no caso moçambicano, mesmo o país não tendo alcançado o status de democrático, observam-se na sua trajetória democrática avanços, principalmente entre 1993 e 1996, com o fim da guerra civil. Atualmente, Moçambique encontra-se como uma anocracia aberta, classificado com +4 pontos em 2013. A inexistência de golpes de Estado também se apresenta como um importante fator que fortaleceu a sua democratização, sendo todos esses fenômenos evidenciados no gráfico a seguir: 


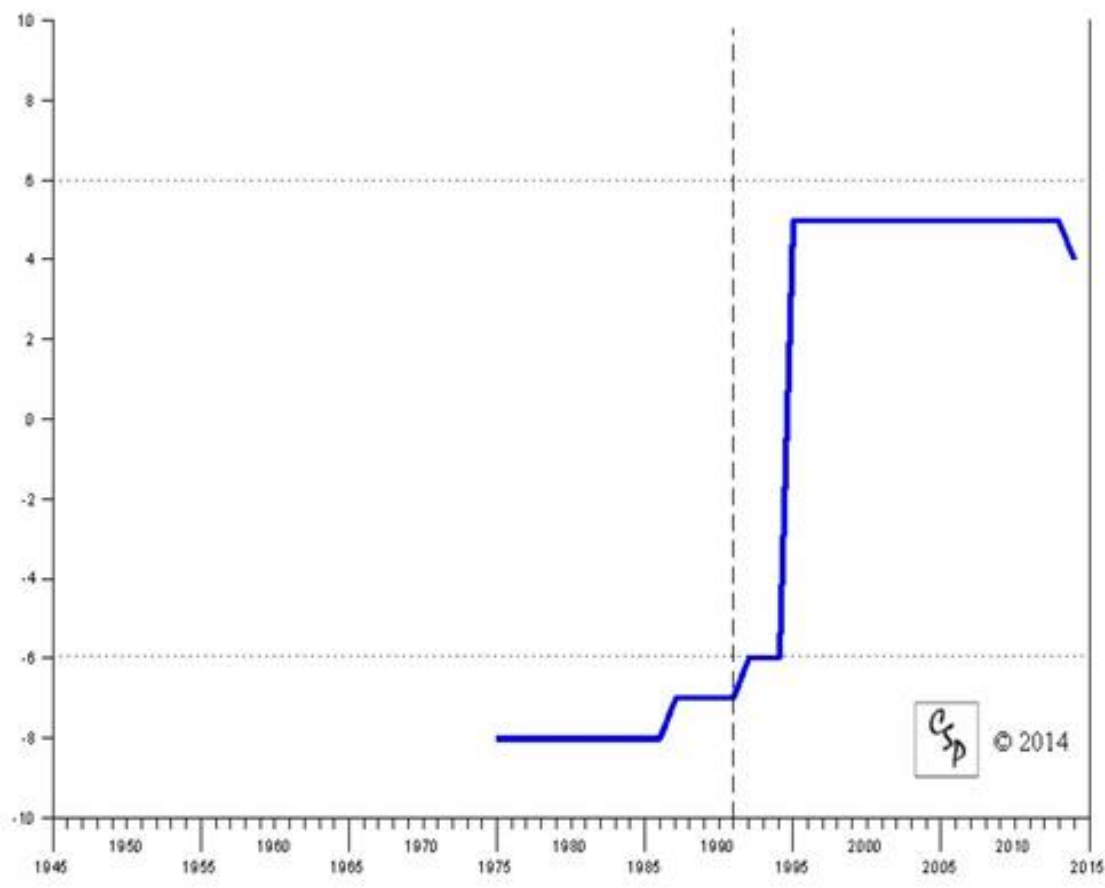

Fonte: POLITY IV, 2016b, s.p.

Já no gráfico referente à Guiné-Bissau, que se encontra exposto abaixo, notamse os avanços e retrocessos da democracia no país desde a década de 1990. O primeiro momento democrático no pós-Guerra Fria remete ao período de forte liberalização política que se iniciou em 1994, com as suas founding elections. Nesse espectro, a classificação do país aumentou de -6 para +5 pontos. Contudo, o golpe de Estado de 1998 (representado pela letra "c" no gráfico) e a subsequente guerra civil (representada pela letra "S") fizeram com que, em 2003, houvesse um declínio de 5 pontos na democracia do país. O segundo momento democrático ocorreu entre 2006 e 2012 no qual país chegou a obter a pontuação +6 , sendo considerado uma "democracia" pelo indicador. Após o golpe de Estado de 2012, o valor reduziu-se novamente. Em 2013, Guiné-Bissau contabilizava +1 ponto, o que a conferia o status de anocracia aberta, refletindo um estágio mais crítico do que o moçambicano. 


\section{Gráfico 25 - Trajetória democrática de Guiné-Bissau de 1974 a 2013 (POLITY IV, 2016c)}

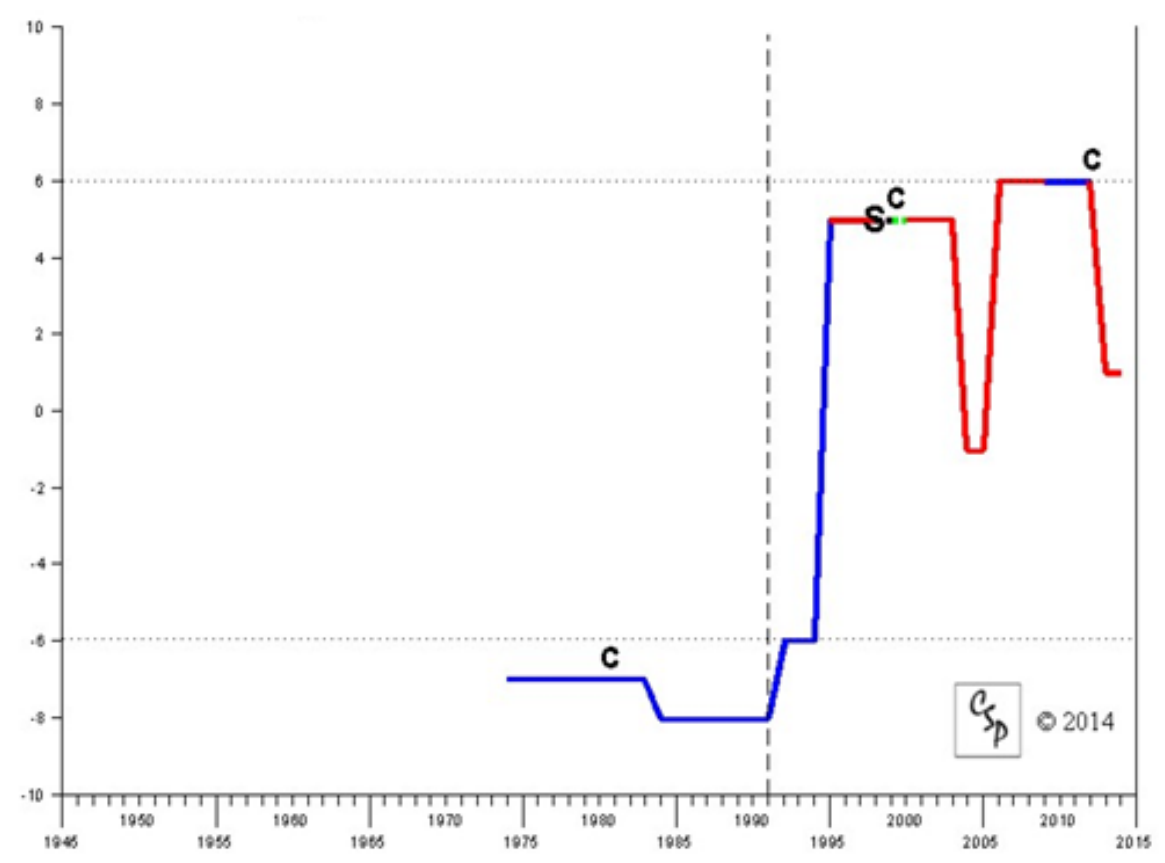

Fonte: POLITY IV, 2016c, s.p.

No gráfico sobre Angola, que se encontra exposto abaixo, é possível identificar o modesto avanço democrático que ocorreu no país de 1995 a 2005, notadamente na fase final da sua guerra civil. Após esse período, ganhos em termos de democracia se estagnaram, conferindo ao regime angolano o status de anocracia fechada, com a pontuação de -2 pontos. Muitas das razões que ajudam a explicar esse resultado para a trajetória política angolana foram mencionados no decorrer deste estudo, ressaltando-se os seguintes aspectos: a) a dificuldade do país em realizar a democratização em um contexto de guerra civil, principalmente depois do fracasso das eleições de 1992 e b) a soberania econômica advinda com a extração dos seus recursos naturais após 2002 (fim da guerra civil), que fez com que o país não precisasse ceder às pressões internacionais para se tornar uma democracia, diminuindo o ritmo da sua abertura política.

Em 2014, Pacheco (2014) realizou uma interessante reflexão sobre a trajetória histórica contemporânea de Angola, contextualizando os avanços políticos e sociais que o país obteve na sua breve existência como Estado soberano, a saber: 
Pergunto-me se há alguma coisa de realmente dignificante para se comemorar em mais um ano da Independência de Angola. Talvez me respondam que sim, que vale a pena celebrar o fim dos horrores da guerra civis que fizeram estremecer o país desde a sua nascença; porque hoje, apesar de tudo, se transita em paz por todos os caminhos enquanto nas aldeias e cidades as populações voltaram a sorrir e a trabalhar sem medo de ser atingidas pelo duelo dos beligerantes; ou ainda que o coração de Angola pulsa de esperança e já ninguém aceita o regresso aos tempos de barbárie. Tenho as minhas dúvidas, porém reconheço que em parte isso é verdade. Se houve alguém que expiou as dores da pátria com o seu próprio sangue por causa dos erros dos senhores da política, esse alguém foi o povo. Ou melhor, os camponeses, os quais no tempo da luta armada suportaram os abusos do aparelho administrativo e repressor da potência ocupante, bem como as perseguições e desmandos de qualquer um dos movimentos de emancipação (PACHECO, 2014, p. 2017).

\section{Gráfico 26 - Trajetória democrática de Angola de 1975 a 2013 (POLITY IV, 2016d)}

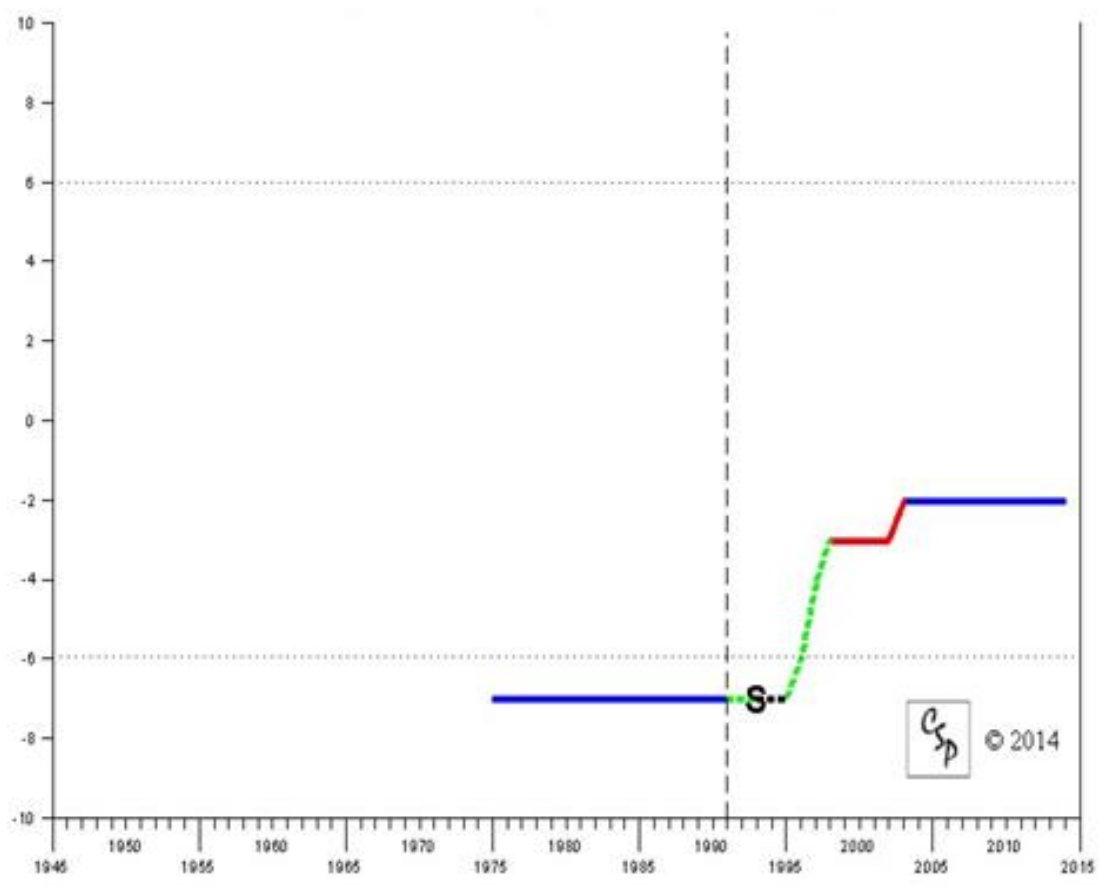

Fonte: POLITY IV, 2016d, s.p.

Na tabela a seguir é possível observar, de maneira comparada, as diferentes fases da trajetória política dos PALOP. Elas abarcam, em linhas gerais, o sistema de partido único, a transição multipartidária e o período da democratização, de acordo com a perspectiva do African Elections (2016), a saber: 
Tabela 59 - Fases da trajetória política dos PALOP de acordo com o African Elections (2016)

\begin{tabular}{|c|c|c|c|c|}
\hline & Primeira Fase & Segunda Fase & Terceira Fase & $\begin{array}{l}\text { Quarta fase e } \\
\text { outras }\end{array}$ \\
\hline Cabo Verde & $\begin{array}{l}1975 \text { - } 1990 \\
\text { Sistema de Partido } \\
\text { único } \\
\text { (PAIGC/PAICV) }\end{array}$ & $\begin{array}{l}1990 \text { - } 1991 \\
\text { Transição } \\
\text { Multipartidária }\end{array}$ & $\begin{array}{l}1991 \text { - presente } \\
\text { Democracia } \\
\text { liberal (livre) }\end{array}$ & \\
\hline $\begin{array}{l}\text { São Tomé e } \\
\text { Príncipe }\end{array}$ & $\begin{array}{l}1975 \text { - } 1990 \\
\text { Sistema de Partido } \\
\text { Único (MLSTP) }\end{array}$ & $\begin{array}{l}1990-1991 \\
\text { Transição } \\
\text { Multipartidária }\end{array}$ & $\begin{array}{l}\text { 1991 - presente } \\
\text { Democracia } \\
\text { liberal (livre) }\end{array}$ & \\
\hline Moçambique & $\begin{array}{l}1975 \text { - } 1990 \\
\text { Sistema de Partido } \\
\text { Único (FRELIMO) }\end{array}$ & $\begin{array}{l}1990-1994 \\
\text { Transição } \\
\text { Multipartidária }\end{array}$ & $\begin{array}{l}1994-2009 \\
\text { Democracia } \\
\text { eleitoral }\end{array}$ & $\begin{array}{l}2009 \text { - presente } \\
\text { Democracia } \\
\text { Emergente } \\
\text { (parcialmente } \\
\text { livre) }\end{array}$ \\
\hline Angola & $\begin{array}{l}1975 \text { - } 1991 \\
\text { Sistema de Partido } \\
\text { Único (MPLA/ } \\
\text { MPLA-PT) } \\
\text { (Presidente José } \\
\text { Eduardo dos Santos) }\end{array}$ & $\begin{array}{l}1991 \text { - } 1992 \\
\text { Transição } \\
\text { Multipartidária } \\
\text { (Presidente José } \\
\text { Eduardo dos } \\
\text { Santos) }\end{array}$ & $\begin{array}{l}1992 \text { - presente } \\
\text { Prática } \\
\text { Democrática } \\
\text { Restrita (não- } \\
\text { livre) (Presidente } \\
\text { José Eduardo dos } \\
\text { Santos) } \\
\end{array}$ & \\
\hline $\begin{array}{l}\text { Guiné- } \\
\text { Bissau }\end{array}$ & $\begin{array}{l}1974 \text { - } 1980 \\
\text { Sistema de Partido } \\
\text { Único (PAIGC) } \\
\text { (presidente Luís } \\
\text { Cabral) }\end{array}$ & $\begin{array}{l}1980-1984 \\
\text { Regime Militar e } \\
\text { Sistema de } \\
\text { Partido Único } \\
\text { (PAIGC) } \\
\text { (Presidente Nino } \\
\text { Vieira) }\end{array}$ & $\begin{array}{l}1984-1991 \\
\text { Sistema de } \\
\text { Partido Único } \\
\text { (PAIGC) }\end{array}$ & 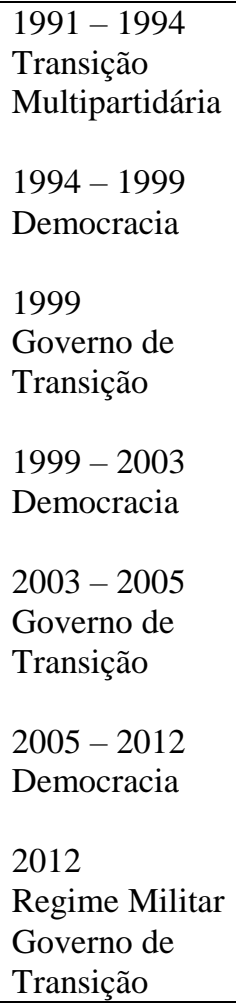 \\
\hline
\end{tabular}

Fonte: Gráfico elaborado pela autora com dados do African Elections (2016).

Após a análise realizada, é possível construir a seguinte tabela no que tange à implantação da democracia liberal nos PALOP após o fim da Guerra Fria: 
Tabela 60 - Análise da presença da democracia liberal dos PALOP em 2016

\begin{tabular}{|l|l|l|l|l|l|}
\hline Variável/ País & $\begin{array}{l}\text { Cabo } \\
\text { Verde }\end{array}$ & $\begin{array}{l}\text { São Tomé e } \\
\text { Príncipe }\end{array}$ & Moçambique & $\begin{array}{l}\text { Guiné- } \\
\text { Bissau }\end{array}$ & Angola \\
\hline $\begin{array}{l}\text { Democracia } \\
\text { liberal }\end{array}$ & $\mathrm{S}$ & $\mathrm{S}$ & $\mathrm{N}^{*}$ & $\mathrm{~N}$ & $\mathrm{~N}$ \\
\hline
\end{tabular}

Fonte: Tabela elaborada pela autora.

No presente Capítulo foi possível compreender a trajetória social, política e econômica dos PALOP desde o início das suas democratizações, que ocorreram na década de 1990. Por meio da análise realizada, foram identificadas semelhanças e diferenças no percurso formativo da construção da democracia na África lusófona, demonstrando os principais aspectos que ajudam a explicar o sucesso da sua implantação nos PALOP insulares e o seu (relativo) insucesso nos PALOP continentais. Nas considerações finais desse estudo, será possível observar, de maneira comparada, os resultados analisados no decorrer dos três estudos de caso da presente da tese. 


\section{CONSIDERAÇÕES FINAIS}

O colapso soviético marcou um momento histórico único no mundo. Entre as suas inúmeras consequências, pode-se citar a liberalização política e econômica de vários países do continente africano já no final da década de 1980. A combinação de diversas variáveis domésticas tais como insularidade, recursos naturais, conflitos armados, desenvolvimento social e crescimento econômico refletiram na diversificada maneira que os Estados se organizaram para buscar a sua inserção no cenário da pós-bipolaridade. Nesse contexto, foi estudado na presente tese o singular conjunto dos PALOP, que apresentou no seu escopo transições democráticas que seguiram trajetórias próprias, nem sempre exitosas, nos últimos 25 anos. Destaca-se, como resultado da análise realizada, que os processos democráticos percorridos por esses países não foram lineares, sendo permeados por uma complexa estrutura que exprime inúmeros avanços e retrocessos.

Além disso, observou-se que a democracia, que de maneira geral é colocada em um segundo plano na produção acadêmica das Relações Internacionais, constituiu uma variável importante que ajudou a explicar parte da formação da agenda da Nova Ordem Mundial pós-1990. Conforme explicitado, o conjunto dos PALOP é interessante para ser analisado, principalmente no âmbito da metodologia comparada, devido ao seu conjunto de similaridades, que vão além da localização no continente africano e da colonização portuguesa. Durante a Guerra Fria, todos eles tornaram-se independentes em relação à Portugal em um período de tempo muito próximo e os processos de formação dos seus Estados nacionais ocorreram sob a égide de partidos marxistas-leninistas (que foram responsáveis pelas lutas de libertação). Esse cenário resultou na contundente influência soviética no universo dos PALOP, com a instauração de Repúblicas Populares pautadas em características autocráticas e monopartidárias. Depois da década de 1990, esses cinco países iniciaram, quase que simultaneamente, os seus processos de democratização, que foram preconizados pela implantação do pluripartidarismo por Manuel Pinto da Costa, presidente de São Tomé e Príncipe. Portanto, apesar das divergências de cada país, foi possível visualizar os PALOP como grupo que compartilha expressivas similaridades.

Os PALOP insulares apresentaram, ao longo desse estudo, uma série de vantagens que propiciaram a melhor implantação da sua democracia quando comparados aos PALOP continentais. Essas vantagens foram desde a questão geográfica e de tamanho 
da população (microestados insulares), até aspectos relacionados à ausência de recursos naturais, à presença de elites políticas mais flexíveis e à ausência de conflitos armados. Dessa forma, o seu sucesso é explicado pela combinação de diversas variáveis que propiciaram um cenário de estabilidade social, política e econômica no momento da liberalização e transição para a democracia.

Durante o período colonial de dominação portuguesa, foram analisadas, no âmbito dos cinco PALOP, dez variáveis independentes antecedentes. Como resultado, tem-se o seguinte cenário: todos se encontram no continente africano; todos vivenciaram o domínio colonial português (VIA2) e, como consequência, nenhum deles possuiu direitos políticos ou expressivas liberdades civis (VIA6) até 1975. Além disso, apesar dos PALOP insulares apresentaram um desenvolvimento social um pouco melhor do que o observado nos seus pares continentais, todos eles demonstraram um baixo valor para essa variável (VIA4) de 1950 a 1975. Da mesma forma, todos os PALOP detinham um reduzido crescimento econômico (VIA3), que se explicava tanto pelas limitações por serem microestados insulares, nos casos de Cabo Verde e São Tomé e Príncipe, quanto pela destruição causada pelas guerras de independência (VIA9) em Moçambique, GuinéBissau e Angola. Destaca-se também que os PALOP insulares apresentavam populações com maior homogeneidade étnica (VIA8), fator que pode ter contribuído indiretamente para a estabilidade social em ambos os países. Por fim, tem-se que a independência de todos os PALOP (VIA10) ocorreu em um período de tempo muito próximo, entre 1973 (Guiné-Bissau) e 1975 (outros PALOP). Destarte, esses dados podem ser observados na seguinte tabela:

Tabela 61 - Análise comparada dos PALOP no período colonial

\begin{tabular}{|l|l|l|l|l|l|l|l|l|l|l|}
\hline & VIA1 & VIA2 & VIA3 & VIA4 & VIA5 & VIA6 & VIA7 & VIA8 & VIA9 & VIA10 \\
\hline Cabo Verde & $\mathrm{S}$ & $\mathrm{S}$ & $\mathrm{N}$ & $\mathrm{N}$ & $\mathrm{S}$ & $\mathrm{N}$ & $\mathrm{N}$ & $\mathrm{N}$ & $\mathrm{N}$ & $\mathrm{S}$ \\
\hline $\begin{array}{l}\text { São Tomé e } \\
\text { Príncipe }\end{array}$ & $\mathrm{S}$ & $\mathrm{S}$ & $\mathrm{N}$ & $\mathrm{N}$ & $\mathrm{S}$ & $\mathrm{N}$ & $\mathrm{N}$ & $\mathrm{N}$ & $\mathrm{N}$ & $\mathrm{S}$ \\
\hline Moçambique & $\mathrm{S}$ & $\mathrm{S}$ & $\mathrm{N}$ & $\mathrm{N}$ & $\mathrm{N}$ & $\mathrm{N}$ & $\mathrm{N}$ & $\mathrm{S}$ & $\mathrm{S}$ & $\mathrm{S}$ \\
\hline $\begin{array}{l}\text { Guiné- } \\
\text { Bissau }\end{array}$ & $\mathrm{S}$ & $\mathrm{S}$ & $\mathrm{N}$ & $\mathrm{N}$ & $\mathrm{N}$ & $\mathrm{N}$ & $\mathrm{N}$ & $\mathrm{S}$ & $\mathrm{S}$ & $\mathrm{S}$ \\
\hline Angola & $\mathrm{S}$ & $\mathrm{S}$ & $\mathrm{N}$ & $\mathrm{N}$ & $\mathrm{N}$ & $\mathrm{N}$ & $\mathrm{S}$ & $\mathrm{S}$ & $\mathrm{S}$ & $\mathrm{S}$ \\
\hline
\end{tabular}

Fonte: Tabela criada pela autora utilizando os dados obtidos no Capítulo 3 da presente tese. 
A análise dos dados acima permitiu identificar o contexto de grande similaridade que pautou o universo de todos os PALOP até 1975. Dessa forma, excluindo-se as variáveis de controle (que apresentam o mesmo resultado para todos os países analisados), tem-se a seguinte tabela:

\section{Tabela 62 - Análise comparada dos PALOP no período colonial sem as variáveis de controle}

\begin{tabular}{|l|l|l|l|l|}
\hline & VIA5 & VIA7 & VIA8 & VIA9 \\
\hline Cabo Verde & S & N & N & N \\
\hline $\begin{array}{l}\text { São Tomé e } \\
\text { Príncipe }\end{array}$ & S & N & N & N \\
\hline Moçambique & N & N & S & S \\
\hline $\begin{array}{l}\text { Guiné- } \\
\text { Bissau }\end{array}$ & N & N & S & S \\
\hline Angola & N & S & S & S \\
\hline
\end{tabular}

Fonte: Tabela criada pela autora utilizando os dados obtidos no Capítulo 3 da presente tese.

No quadro acima, os valores referentes à Cabo Verde e São Tomé e Príncipe se apresentaram idênticos. Da mesma forma, a única diferença de resultado entre os PALOP continentais se encontra expressa na variável pautada nos recursos naturais (VIA7), que apresenta um resultado positivo somente para Angola, devido à grande presença de petróleo e diamantes no país.

Já no âmbito do regime de partido único, que perdurou de 1975 até a década de 1990, tem-se que todos os PALOP se tornaram repúblicas populares com uma forte influência soviética (VIA11), encontrando-se imersos em um cenário doméstico caracterizado pela reduzida presença de direitos políticos e liberdades civis (VIA12). Nesse contexto, a existência de guerras civis antes da democratização em Moçambique e Angola (VIA16) ${ }^{63}$ fez com que o crescimento econômico (VIA13) dos PALOP insulares, mesmo com todas as suas limitações, se apresentasse mais estável e maior do que o

\footnotetext{
${ }^{63}$ Conforme explicitado anteriormente, a guerra civil da Guiné-Bissau apresentou proporções mais reduzidas do que as observadas em Moçambique e Angola. Apesar do conflito ter ocorrido entre 1998 e 1999, ele se encontra inserido no escopo dessa variável porque a mesma abarca todo o período do pósindependência dos PALOP, não se limitando a 1990. Vale destacar também que o referido conflito ocorreu alguns anos depois do início da democratização guineense, afetando profundamente a economia do país depois de 1990. Nesse contexto, o baixo desenvolvimento econômico do país desde 1975 é um reflexo tanto da guerra de independência quanto da instabilidade política constante, em uma arena doméstica permeada por golpes de Estado.
} 
observado nos PALOP continentais. Da mesma forma que o ocorrido no âmbito do crescimento econômico, esses conflitos civis também afetaram o desenvolvimento social dos PALOP continentais (VIA14), que obtiveram resultados significativamente menores do que os dos seus pares insulares. Finalmente, tem-se que as elites políticas dos PALOP insulares e de Moçambique apresentaram um perfil mais flexível (VIA15) e favorável à democratização no final da década de 1980 e início de 1990, mostrando-se mais dispostas para realizar as negociações em prol da liberalização e transição democráticas quando comparadas às elites de Guiné-Bissau e Angola. Nesse ínterim, essas informações podem ser identificadas na seguinte tabela:

Tabela 63 - Análise comparada dos PALOP no período do regime de partido único

\begin{tabular}{|l|l|l|l|l|l|l|}
\hline & VIA11 & VIA12 & VIA13 & VIA14 & VIA15 & VIA16 \\
\hline Cabo Verde & S & N & S & S & S & N \\
\hline $\begin{array}{l}\text { São Tomé e } \\
\text { Príncipe }\end{array}$ & S & N & S & S & S & N \\
\hline Moçambique & S & N & N & N & S & S \\
\hline $\begin{array}{l}\text { Guiné- } \\
\text { Bissau }\end{array}$ & S & N & N & N & N & S \\
\hline Angola & S & N & N & N & N & S \\
\hline
\end{tabular}

Fonte: Tabela criada pela autora utilizando os dados obtidos no Capítulo 4 da presente tese.

Conforme se verifica acima, no âmbito do regime de partido único, mais uma vez todas as variáveis dos PALOP insulares foram iguais. Do mesmo modo, as variáveis referentes aos PALOP continentais também apresentaram resultados semelhantes (com a exceção do perfil das elites políticas), fator que explica a análise desses cinco países em dois grupos tipológicos: insulares e continentais. Nesses cenários comparativos, observou-se uma maior estabilidade social, política e econômica dos PALOP insulares no momento da democratização (VIP). Dessa forma, o resultado da tabela sugere que o resultado dessa variável em Cabo Verde e em São Tomé e Príncipe tenha sido influenciado por um conjunto importante de fatores presentes nas suas arenas domésticas até 1990, a saber:

- Constituição dos países como microestados insulares;

- Inexistência de conflitos armados em seus territórios (tanto guerras de independência quanto guerras civis), que se explica pelo fato deles serem microestados insulares; 
- Presença de um desenvolvimento social crescente desde a independência;

- Presença de um relativo crescimento econômico (potencial de crescimento em um contexto sem crises econômicas advindas de conflitos armados em seus territórios);

- Poucas tensões entre as suas elites políticas;

- Elites políticas flexíveis;

- Baixa fragmentação social e

- Ausência de recursos naturais.

Além de todos esses fatores, que de maneira longitudinal explicam o sucesso da democracia nos PALOP insulares, destaca-se o desejo da população desses Estados em realizar a alternância de poder partidário já nas primeiras eleições de 1991. Esse fenômeno foi observado nos resultados das primeiras eleições legislativas e presidenciais de ambos os países, nos quais a mudança política foi realizada com a vitória dos partidos de oposição, representados pelo MpD em Cabo Verde e pela ADI em São Tomé e Príncipe (destacando-se que a ADI obteve maior votação no Parlamento, sendo eleito no âmbito presidencial um candidato independente, mas de oposição ao MLSTP).

Por outro lado, a referida alternância efetiva de poder partidário (VII6) não ocorreu tanto em Angola quanto em Moçambique, que permanecem até a atualidade com o mesmo partido político no poder. Além disso, houve apenas um momento na GuinéBissau no qual o país não foi liderado pelo PAIGC, que ocorreu durante as eleições de 1999/2000. Contudo, no caso guineense a transição não foi efetiva porque o presidente eleito não foi capaz de terminar o seu mandato, sofrendo um golpe de Estado. Dessa forma, a análise das referidas variáveis no âmbito dos PALOP continentais até 1990 sugere que o (relativo) insucesso das suas democratizações se explica pelos mesmos motivos expostos anteriormente nos contextos cabo-verdiano e são tomense, sendo eles:

- Existência de conflitos armados em seus territórios (tanto guerras de independência quanto guerras civis);

- Presença de um desenvolvimento social fragilizado com baixas taxas de crescimento desde o período colonial; 
- Presença de um reduzido crescimento econômico (baixo potencial de crescimento em um contexto de crises econômicas advindas de conflitos armados em seus territórios);

- Grandes tensões entre as suas elites políticas;

- Elites políticas inflexíveis (nos casos guineense e angolano);

- Fragmentação social e

- Presença de recursos naturais no caso angolano (que é o mais autocrático dos PALOP).

É importante destacar que Moçambique apresentou os mesmos resultados que Guiné-Bissau e Angola até o início de 1990. A partir desse momento, o comportamento das elites do país passou a pautar-se em uma maior flexibilidade, favorecendo a democratização. Dessa forma, tem-se que esse fenômeno exerceu um grande impacto na trajetória política do país, fazendo com que a sua transição para a democracia apresentasse mais sucesso do que a dos outros PALOP continentais. Como consequência, houve uma ampliação dos direitos políticos e liberdades civis (VII2), bem como o fortalecimento das suas instituições democráticas (VII5), fazendo com que Moçambique tivesse, no ano de 2017, a classificação da sua democracia como "parcialmente livre" (FREEDOM HOUSE, 2017a).

Após compreender o contexto interativo das variáveis domésticas desses Estados, observa-se que essas configurações internas foram essenciais para explicar o sucesso ou insucesso das transformações democráticas que moldariam o futuro de cada realidade estudada. Do início da transição para a democracia (1990) até a atualidade, é possível identificar o seguinte quadro comparado no âmbito dos PALOP:

Tabela 64 - Análise comparada dos PALOP no período da democratização (pós1990)

\begin{tabular}{|l|l|l|l|l|l|l|l|l|l|}
\hline & VIP & VEXT & VII1 & VII2 & VII3 & VII4 & VII5 & VII6 & VD \\
\hline Cabo Verde & S & S & S & S & S & S & S & S & S \\
\hline $\begin{array}{l}\text { São Tomé e } \\
\text { Príncipe }\end{array}$ & S & S & S & S & S & S & S & S & S \\
\hline Moçambique & N & S & S & $\mathrm{N}^{*}$ & S & N & N* & N & N* $^{*}$ \\
\hline $\begin{array}{l}\text { Guiné- } \\
\text { Bissau }\end{array}$ & N & S & S & N & S & N & N & N & N \\
\hline Angola & N & S & S & N & S & N & N & N & N \\
\hline
\end{tabular}

Fonte: Tabela criada pela autora utilizando os dados obtidos no Capítulo 5 da presente tese. 
A análise da tabela com os resultados do período da democratização evidencia que, durante esse período, todos os PALOP sofreram uma grande pressão internacional para iniciarem a democratização após o fim da Guerra Fria (VEXT), iniciando o seu processo de liberalização política e transição para a democracia praticamente no mesmo momento: final da década de 1980 e início de 1990 (VII1). No que tange ao crescimento econômico (VII3), tem-se que todos eles apresentaram um crescimento importante (mesmo que em níveis distintos). No âmbito dos PALOP insulares, essa relação pode ser explicada pelo recebimento de recursos financeiros internacionais relacionados à sua trajetória democrática. Já no caso dos PALOP continentais (notadamente Angola e Moçambique), sugere-se que esses resultados sejam explicados, pelo menos no seu estágio inicial, tanto pelo angariamento de recursos conectados aos seus ganhos democráticos, quanto, principalmente, ao restabelecimento das suas economias com o fim das guerras civis. Nesse ínterim, destaca-se que a Guiné-Bissau, mesmo com a grave crise econômica perpassada após o conflito armado em 1998/1999, também apresentou ganhos econômicos nesse período, com o recebimento (mesmo que relativamente reduzido) de ajuda oficial internacional (ver Anexo F).

Já no âmbito do desenvolvimento social (VII4), tem-se que Cabo Verde e São Tomé e Príncipe obtiveram resultados expressivos durante a democratização. Contudo, ao contrário do observado na análise do crescimento econômico, o desenvolvimento social de todos os PALOP continentais apresentou ganhos reduzidos, permitindo concluir que a democratização e o pós-guerra civil desses países propiciaram uma relativa reestruturação econômica (notadamente de Angola e Moçambique), não refletindo na melhora significativa da qualidade de vida da sua população.

Além disso, verificou-se que após 1990, os direitos políticos e as liberdades civis (VII2) foram plenamente implantados somente nos PALOP insulares, denotando uma classificação intermediária no contexto moçambicano. Destarte, por meio desta abordagem comparada focalizada nos aspectos políticos, sociais e econômicos dos PALOP desde o período colonial, foi possível identificar os variados fatores domésticos que explicam o êxito da democracia liberal em Cabo Verde e São Tomé e Príncipe, o seu relativo insucesso em Moçambique e o seu insucesso na Guiné-Bissau e em Angola. Após a exclusão das variáveis de controle de todas as tabelas apresentadas desde o domínio português, a análise dos três períodos estudados permitiu criar a seguinte tabela: 
Tabela 65 - Análise comparada dos PALOP de 1950 a 2015 sem as variáveis de controle

\begin{tabular}{|l|l|l|l|l|l|l|l|l|l|l|l|l|l|l|}
\hline & $\begin{array}{l}\text { VIA } \\
5\end{array}$ & $\begin{array}{l}\text { VIA } \\
7\end{array}$ & $\begin{array}{l}\text { VIA } \\
8\end{array}$ & $\begin{array}{l}\text { VIA } \\
9\end{array}$ & $\begin{array}{l}\text { VIA } \\
13\end{array}$ & $\begin{array}{l}\text { VIA } \\
14\end{array}$ & $\begin{array}{l}\text { VIA } \\
15\end{array}$ & $\begin{array}{l}\text { VIA } \\
16\end{array}$ & VIP & VII2 & VII4 & VII5 & VII6 & VD \\
\hline Cabo Verde & $\mathrm{S}$ & $\mathrm{N}$ & $\mathrm{N}$ & $\mathrm{N}$ & $\mathrm{S}$ & $\mathrm{S}$ & $\mathrm{S}$ & $\mathrm{N}$ & $\mathrm{S}$ & $\mathrm{S}$ & $\mathrm{S}$ & $\mathrm{S}$ & $\mathrm{S}$ & $\mathrm{S}$ \\
\hline $\begin{array}{l}\text { São Tomé e } \\
\text { Príncipe }\end{array}$ & $\mathrm{S}$ & $\mathrm{N}$ & $\mathrm{N}$ & $\mathrm{N}$ & $\mathrm{S}$ & $\mathrm{S}$ & $\mathrm{S}$ & $\mathrm{N}$ & $\mathrm{S}$ & $\mathrm{S}$ & $\mathrm{S}$ & $\mathrm{S}$ & $\mathrm{S}$ & $\mathrm{S}$ \\
\hline Moçambique & $\mathrm{N}$ & $\mathrm{N}$ & $\mathrm{S}$ & $\mathrm{S}$ & $\mathrm{N}$ & $\mathrm{N}$ & $\mathrm{S}$ & $\mathrm{S}$ & $\mathrm{N}$ & $\mathrm{N}$ & $\mathrm{N}$ & $\mathrm{N}^{*}$ & $\mathrm{~N}$ & $\mathrm{~N}^{*}$ \\
\hline Guiné-Bissau & $\mathrm{N}$ & $\mathrm{N}$ & $\mathrm{S}$ & $\mathrm{S}$ & $\mathrm{N}$ & $\mathrm{N}$ & $\mathrm{N}$ & $\mathrm{S}$ & $\mathrm{N}$ & $\mathrm{N}$ & $\mathrm{N}$ & $\mathrm{N}$ & $\mathrm{N}$ & $\mathrm{N}$ \\
\hline Angola & $\mathrm{N}$ & $\mathrm{S}$ & $\mathrm{S}$ & $\mathrm{S}$ & $\mathrm{N}$ & $\mathrm{N}$ & $\mathrm{N}$ & $\mathrm{S}$ & $\mathrm{N}$ & $\mathrm{N}$ & $\mathrm{N}$ & $\mathrm{N}$ & $\mathrm{N}$ & $\mathrm{N}$ \\
\hline
\end{tabular}

Fonte: Tabela criada pela autora utilizando os dados obtidos nos Capítulo 3, 4 e 5 da presente tese.

Com a exceção das variáveis referentes aos recursos naturais (VIA7) e ao perfil das elites políticas (VIA15), é possível observar padrões de similaridade tanto nos valores dos PALOP insulares quanto nos valores dos PALOP continentais. Contudo, é importante ressaltar que o cenário moçambicano deve ser analisado de maneira distinta, pois revela um caráter intermediário singular no âmbito da democratização no universo dos PALOP. A visualização desses dados em três grupos tipológicos (com a exceção da VIA 7 e da VIA15) encontra-se na tabela a seguir:

Tabela 66 - Análise tipológica comparada dos PALOP de 1950 a 2015 sem as variáveis de controle

\begin{tabular}{|l|l|l|l|l|l|l|l|l|l|l|l|l|l|}
\hline & $\begin{array}{l}\text { VIA } \\
5\end{array}$ & $\begin{array}{l}\text { VIA } \\
8\end{array}$ & $\begin{array}{l}\text { VIA } \\
9\end{array}$ & $\begin{array}{l}\text { VIA } \\
13\end{array}$ & $\begin{array}{l}\text { VIA } \\
14\end{array}$ & $\begin{array}{l}\text { VIA } \\
15\end{array}$ & $\begin{array}{l}\text { VIA } \\
16\end{array}$ & VIP & VII2 & VII4 & VII5 & VII6 & VD \\
\hline PALOP insulares & $\mathrm{S}$ & $\mathrm{N}$ & $\mathrm{N}$ & $\mathrm{S}$ & $\mathrm{S}$ & $\mathrm{S}$ & $\mathrm{N}$ & $\mathrm{S}$ & $\mathrm{S}$ & $\mathrm{S}$ & $\mathrm{S}$ & $\mathrm{S}$ & $\mathrm{S}$ \\
\hline Moçambique & $\mathrm{N}$ & $\mathrm{S}$ & $\mathrm{S}$ & $\mathrm{N}$ & $\mathrm{N}$ & $\mathrm{S}$ & $\mathrm{S}$ & $\mathrm{N}$ & $\mathrm{N} *$ & $\mathrm{~N}$ & $\mathrm{~N}^{*}$ & $\mathrm{~N}$ & $\mathrm{~N}^{*}$ \\
\hline $\begin{array}{l}\text { PALOP continentais } \\
\text { (Guiné-Bissau e } \\
\text { Angola) }\end{array}$ & $\mathrm{N}$ & $\mathrm{S}$ & $\mathrm{S}$ & $\mathrm{N}$ & $\mathrm{N}$ & $\mathrm{N}$ & $\mathrm{S}$ & $\mathrm{N}$ & $\mathrm{N}$ & $\mathrm{N}$ & $\mathrm{N}$ & $\mathrm{N}$ & $\mathrm{N}$ \\
\hline
\end{tabular}

Fonte: Tabela criada pela autora utilizando os dados obtidos nos Capítulo 3, 4 e 5 da presente tese.

Analisando-se somente a VIP, a VEXT e a VD, tem-se o seguinte quadro: 
Tabela 67 - Análise comparada dos PALOP considerando a variável externa, a variável independente principal e a variável dependente

\begin{tabular}{|l|l|l|l|}
\hline & VEXT & VIP & VD \\
\hline $\begin{array}{l}\text { PALOP } \\
\text { insulares }\end{array}$ & $\mathrm{S}$ & $\mathrm{S}$ & $\mathrm{S}$ \\
\hline Moçambique & $\mathrm{S}$ & $\mathrm{N}$ & $\mathrm{N}^{*}$ \\
\hline $\begin{array}{l}\text { PALOP } \\
\text { continentais } \\
\text { (Guiné-Bissau } \\
\text { e Angola) }\end{array}$ & $\mathrm{S}$ & $\mathrm{N}$ & $\mathrm{N}$ \\
\hline
\end{tabular}

Fonte: Tabela criada pela autora utilizando os dados obtidos nos Capítulo 3, 4 e 5 da presente tese.

O resultado acima confirma a hipótese da tese, revelando que, em contextos nos quais a democratização se encontra impulsionada por uma variável externa, o sucesso da democracia liberal é explicado primordialmente pela estabilidade social, política e econômica dos países no momento da mudança de regime. Nesse ínterim, o estudo demonstrou empiricamente a veracidade da principal premissa defendida pelos autores da primeira geração da literatura de democratização: as variáveis domésticas são mais importantes do que as variáveis externas para explicar o processo democrático de um país. Contudo, no caso dos PALOP, a variável externa foi essencial para fomentar a liberalização e transição para a democracia, não sendo suficiente para assegurar o seu êxito. Logo, tem-se que o sucesso da democracia na África lusófona dependeu de uma combinação tanto da variável externa quanto das variáveis domésticas, confirmando o modelo exposto da Introdução deste trabalho, a saber:

Figura 12 - Modelo de análise: democratização e intervenção externa Intervenção externa para a democratização

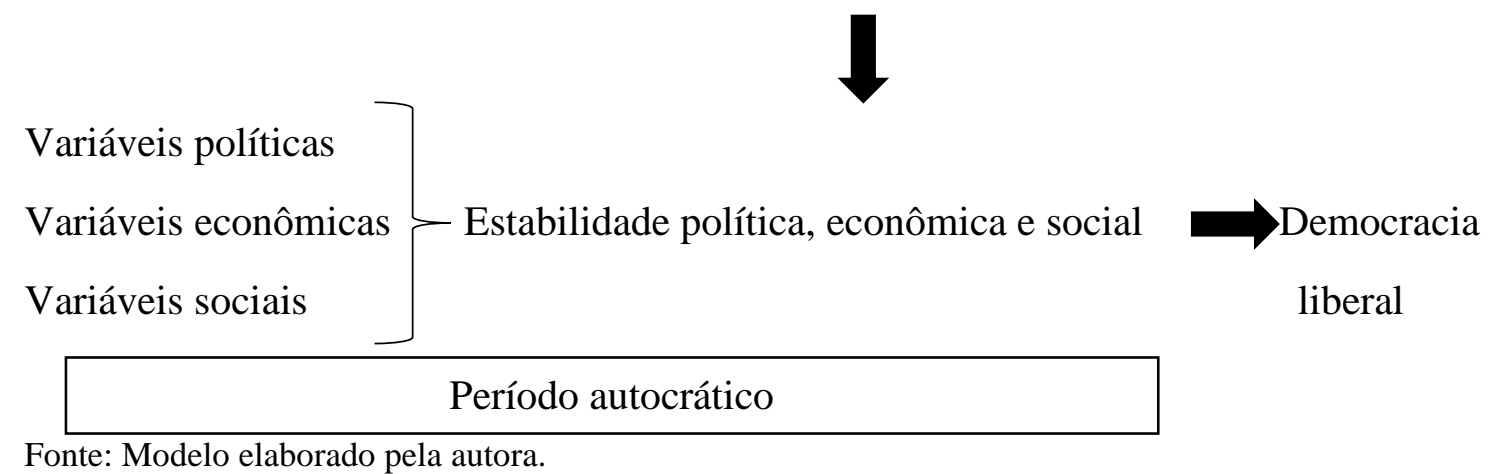

Fonte: Modelo elaborado pela autora. 
Considerando os resultados supracitados, observa-se que no âmbito da cadeia causal, a análise dos PALOP insulares apresenta-se da seguinte maneira:

Figura 13 - Process Tracing: Trajetória democrática dos PALOP insulares

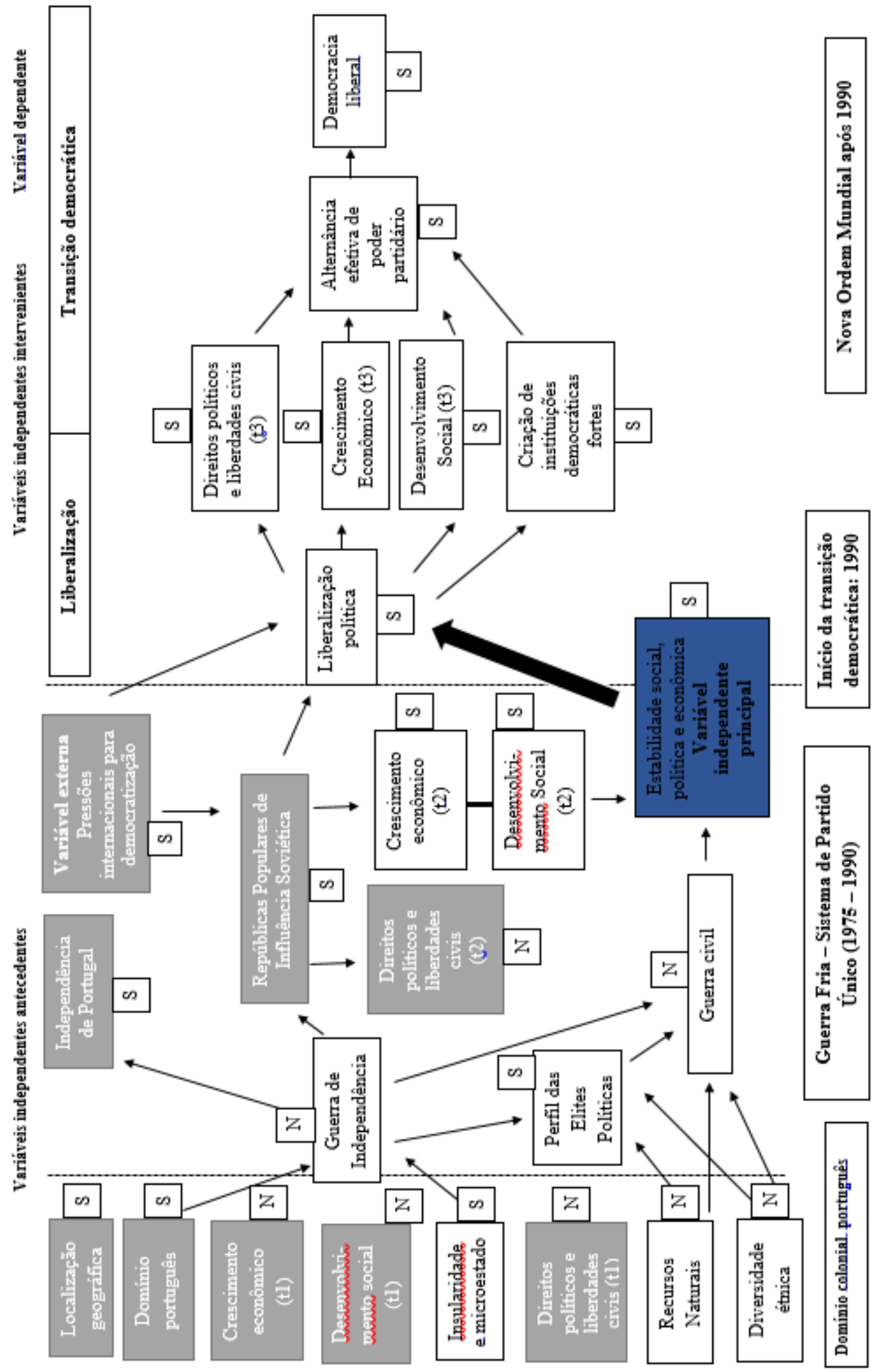


Já no contexto dos PALOP continentais, notam-se os seguintes resultados na cadeia causal proposta por este estudo:

Figura 14 - Process Tracing: Trajetória dmocrática dos PALOP continentais

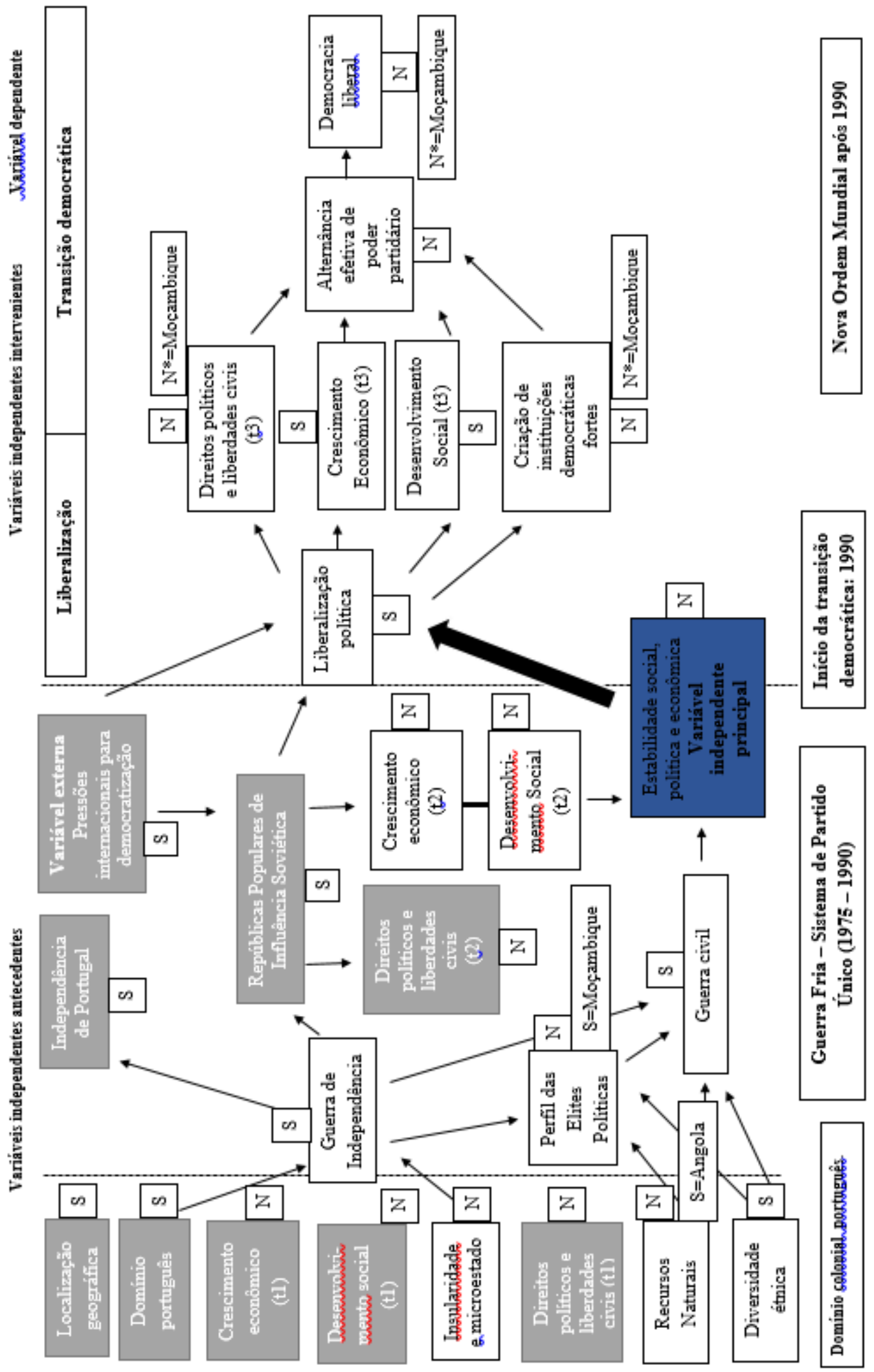


Ao se analisar as variáveis mais importantes na referida cadeia, tem-se que, em linhas gerais, o fato de Cabo Verde e São Tomé e Príncipe serem microestados insulares influenciou fortemente a ausência de guerras de independência nos seus territórios, fomentando uma arena doméstica pacífica e pouco propícia à presença de guerras civis (que nos PALOP continentais tinham como origem a disputa pelo poder após as guerras de independência, mesmo no caso guineense, que ocorreu décadas depois, em 1998/1999). Dessa forma, a inexistência de conflitos armados nos PALOP insulares ajudou a gerar maior estabilidade social, política e econômica no seu território, fazendo com que as suas elites, que já tinham um caráter mais flexível, iniciassem o processo de democratização de maneira rápida e efetiva. Nesse contexto, a alternância efetiva de poder partidário ajudou a legitimar a transição democrática desses países, resultando no êxito da sua democracia liberal.

Seguindo essa mesma lógica de análise, a localização geográfica (continental) de Moçambique, Guiné-Bissau e Angola permitiu a instauração de guerras de independência contra os portugueses, que ocorreram por meio de guerrilhas. Nesse contexto, conforme citado anteriormente, houve uma intensa disputa pelo poder após 1975, resultando em duradouras guerras civis em Angola e Moçambique logo no pósindependência. No caso guineense, a guerra civil mostrou-se mais reduzida e ocorreu somente em 1998, mas com raízes ainda pautadas nas rivalidades de diferentes grupos políticos que se formaram desde a construção do Estado Nacional na década de 1970. A fragmentação social desses países refletia-se tanto na sociedade quanto no comportamento das suas elites, que se mostravam mais inflexíveis e pouco inclinadas a ceder o poder a movimentos de oposição. Como exceção, tem-se o comportamento das elites moçambicanas, que já no início da democratização mostraram-se bastante flexíveis à mudança de regime político no país. Os conflitos armados geraram grande instabilidade social, política e econômica nos PALOP continentais, fazendo com que a democratização ocorresse de maneira lenta e repleta de obstáculos. Nesses cenários, 25 anos depois do início da liberalização, a democracia liberal representou um relativo sucesso na cena moçambicana, mas poucos avanços em Angola e Guiné-Bissau.

No artigo “África na Ordem Internacional do Século XXI: mudanças epidérmicas ou ensaios de autonomia decisória”, Saraiva (2008) indaga se as diversas mudanças ocorridas do continente africano na contemporaneidade são epidérmicas (superficiais) ou 
expressam reflexos consistentes da sua inserção soberana. No caso dos PALOP, em 2007, o autor demonstra diversas mudanças positivas que foram observadas nas suas arenas domésticas, a saber:

\begin{abstract}
Angola cresce seu PIB anual em torno de quase 20\%, um dos maiores do mundo. Cabo Verde assiste a sua internacionalização crescente, mesmo nas condições difíceis do arquipélago. São Tomé e Príncipe normalizam sua vida política e abrem as portas para os investimentos na sua plataforma petrolífera. A Guiné-Bissau, apesar dos problemas que passou na última década da história, assiste sopro de esperança de normalização política. Moçambique, mais até que os acima citados, é caso modelar de inserção internacional altaneira na ordem internacional do início do século XXI [...] As razões para o otimismo derivam de fatos como a democratização em ritmo mais forte que muitos dos Estados africanos, reformas econômicas liberalizantes que criaram confiança nos mercados, crescimento do PIB na ordem de $7 \%$ nos últimos anos, inflação domada, diminuição da vulnerabilidade externa, reservas internacionais consideradas satisfatórias para uma economia modesta e acesso a financiamentos internacionais (SARAIVA, 2008, p. 99).
\end{abstract}

Realizar previsões sobre o instável mosaico africano não é tarefa fácil. Contudo, por meio do presente estudo de doutoramento, foi possível perceber que, ao menos nos PALOP insulares, a implantação da democracia liberal mostrou-se consistente e duradoura, permitindo desde 1990 a sua inserção na arena global do pós-Guerra Fria. Já nos PALOP continentais, as diversas transformações democráticas não se constituíram necessariamente como "epidérmicas”, mas revelaram na sua essência um caráter de maior fragilidade no âmbito dos direitos políticos e liberdades civis, notadamente em GuinéBissau e Angola. Dessa forma, é necessário analisar o presente trabalho utilizando uma perspectiva de "otimismo cauteloso" 64 .

Por fim, tem-se que este estudo doutoral apresentou um conhecimento sistematizado sobre uma temática ainda pouco explorada, principalmente no Brasil. Espera-se que a presente tese possa ser utilizada como subsídio para pesquisas futuras pautadas na democratização dos PALOP e em tópicos afins. Além disso, nesta investigação foi possível identificar as variáveis que, em perspectiva histórica e comparada, mais influenciaram o sucesso ou insucesso da implantação da democracia nos países supracitados. Dessa forma, almeja-se que futuramente, com maior informação e material de apoio, a comunidade acadêmica que estuda esse assunto, a sociedade civil e

\footnotetext{
${ }^{64}$ O termo "otimismo cauteloso" foi utilizado por Saraiva (2008) no artigo "África na Ordem Internacional do Século XXI: mudanças epidérmicas ou ensaios de autonomia decisória".
} 
as elites nacionais possam trabalhar conjuntamente a fim de ampliar a qualidade da democracia dos PALOP, fortalecendo os seus direitos políticos e liberdades civis. 


\section{REFERÊNCIAS BIBLIOGRÁFICAS}

ACEMOGLU, Daron; ROBINSON, James. Natural Resources and Political Institutions: Democracy. Why Nations Fail Blog. May $29^{\text {th }}$ 2013. Disponível em http://whynationsfail.com/blog/2013/5/29/natural-resources-and-political-institutionsdemocracy.html Acesso em 05 de janeiro de 2017.

AFONSO, Aniceto. Aspectos da Guerra Colonial (1961 - 1975). Texto base de uma conferência efetuada no Arquivo Histórico Ultramarino em 25 de junho de 2009. Blogue História Lusófona, Instituto de Investigação Científica Tropical (IICT). Disponível em http://www2.iict.pt/?idc=102\&idi=15621 Acesso em 05 de dezembro de 2016.

AFRICAN ELECTIONS. African Elections Database - A database of election results in Sub-saharan Africa, 2016. Disponível em http://africanelections.tripod.com/ Acesso em 10 de dezembro de 2016.

AGOSTINHO, Feliciano. Guerra em Angola: As Heranças da Luta de Libertação e a Guerra Civil. Dissertação de Mestrado em Ciências Militares, Academia Militar de Portugal. Lisboa, Setembro de 2011. Disponível em http://comum.rcaap.pt/bitstream/10400.26/11546/2/Guerra\%20_em_Angola.pdf Acesso em 10 de desembro de 2016.

ANDRINGA, 2016. 1961: O ano de todos os perigos. Disponível em http://www.guerracolonial.org/index.php?content=113 Acesso em 10 de janeiro de 2017.

ANCKAR, Dag. Why are Small States Democracies? The Round Table, vol. 91, Issue 365, pp. 375-390, 2002.

BALBINOTTO NETO, Giácomo. Crescimento Econômico e Inflação. Notas de Aula. Teoria Macroeconômica II. Universidade Federal do Rio Grande do Sul, 2016. Disponível

em https://view.officeapps.live.com/op/view.aspx?src=http\%3A\%2F\%2Fppge.ufrgs.br\%2F giacomo $\% 2$ Farquivos $\% 2$ Feco02237\%2Faulas $\% 2520$ -

$\% 2520$ giacomo $\% 2$ FTEORIAS $\% 2520$ DA $\% 2520$ INFLA $\% 25 \mathrm{C} 3 \% 2587 \% 25 \mathrm{C} 3 \% 2583 \mathrm{O}$

$\%$ 2FCRESCIMENTO $\% 2520 \% 26 \% 2520 \% 2520$ INFLA $\% 25 \mathrm{C} 3 \% 2587 \% 25 \mathrm{C} 3 \% 2583 \mathrm{O}$

\%2FCRESCIMENTO $\% 2520$ ECON\%25C $\% 2594 \mathrm{MICO} \% 2520 \% 26 \% 2520$ INFLA $\% 25$

C3\%2587\%25C3\%2583O.ppt Acesso em 05 de janeiro de 2017.

BANCO MUNDIAL. World Data Bank, 2015a. Disponível em http://databank.worldbank.org/data/reports.aspx?Code=SP.POP.TOTL\&id=af3ce82b\&r eport_name=Popular_indicators\&populartype=series\&ispopular=y Acesso em 05 de janeiro de 2017.

Cabo Verde: Aspectos Gerais - Panorama Histórico, 2016a. Disponível em http://www.worldbank.org/pt/country/caboverde/overview Acesso em 05 de janeiro de 2017. 
Angola: Aspectos Gerais - Panorama Histórico, 2016b. Disponível em http://www.worldbank.org/pt/country/angola/overview Acesso em 10 de janeiro de 2017.

BARROS, Edlena. Massacre em Batepá Despertou Leonel Mário D’Alva para a luta independentista. DW, Especial 40 Anos de 25 de Abril e de Independência - São Tomé e Príncipe. Publicado em 23 de setembro de 2014. Disponível em http://dw.com/p/1DH4r Acesso em 05 de dezembro de 2016.

BEACH, Derek; PEDERSEN, Rasmus B. What is process tracing actually tracing? The three variants of process tracing methods and their uses and limitations. Paper presented at The American Political Science Association Annual Meeting. Seattle, September 1 $-4,2011$.

BEISSINGER, Mark. A New Look at Ethnicity and Democratization. Journal of Democracy, vol. 19, n. 03, pp. 85-97, 2008.

BESSA, Sebastião. O Sistema Eleitoral Angolano: a Consolidação Democrática Através da Garantia de Eleições Livres. Dissertação de Mestrado. Departamento de Direito da Universidade Autônoma de Lisboa. Lisboa, 2014. Disponível em http://repositorio.ual.pt/bitstream/11144/624/1/Disserta\%C3\%A7\%C3\%A3o\%20de\%20 Mestrado\%20-\%20Sebasti\%C3\%A3o\%20Bessa.pdf Acesso em 05 de janeiro de 2017.

BESLEY; Timothy; KUDAMATSU, Masayuki. Health and Democracy. American Economic Review, vol. 96, n. 02, pp. 313-318, 2006.

BERGGREN, OLLE. Democracy and Human Development: A Cross-National Analysis. Thesis at the Department of Political Science, Lund University, 2012.

BONET, Antoni Jesús. La Democracia Revolucionaria, un Proyecto para el siglo XXI (Entrevista a Boaventura de Sousa Santos). Revista Internacional de Filosofía Política, ISSN 1132-9432, $\mathrm{N}^{\mathrm{o}}$ 35, 2010, págs. 117-148. Disponível em http://www.boaventuradesousasantos.pt/media/EntrevistaRIFP_35.pdf Acesso em 5 de dezembro de 2016.

CAMPBELL, David. The Basic Concept for the Democracy Ranking of the Quality of Democracy. Democracy Ranking. Viena, 2008. Disponível em http://www.democracyranking.org/downloads/basic_concept_democracy_ranking_2008 _A4.pdf Acesso em 1 de junho de 2015.

CAMPOS, Josilene Silva. As representações da Guerra Civil e a Construção da Nação Moçambicana nos Romances de Mia Couto (1992-2000). Dissertação de Mestrado. Universidade Federal de Goiás. Programa de Pós-Graduação em História, $2009 . \quad$ Disponível em https://portais.ufg.br/up/113/o/Disserta___o_Josilene_Silva_Campos.pdf_Acesso em 05 de janeiro de 2017.

CARDOSO, Humberto. O Partido Único em Cabo Verde - Um Assalto à Esperança. Praia: Pedro Cardoso Livraria, 2a edição, 2016. 
CASTRO SANTOS, Maria Helena. O Processo de Democratização da Terceira Onda de Democracia: quanto pesam as variáveis externas? Boletim Meridiano 47, No. 115, 2010a, p. 15-18.

. O Papel dos Estados Unidos na Nova Ordem Internacional e as Intervenções Militares Americanas no Pós-Guerra Fria: que lugar ocupa aí a democracia? Boletim Meridiano 47, $\mathrm{n}^{\mathrm{o}}$ 117, 2010b, p.18 a 22.

CAVALCANTI, Carlos A. O processo de democratização em Angola e Moçambique: Um estudo comparativo. Dissertação de Mestrado, Brasília: Universidade de Brasília, 2002.

CENTER FOR SYSTEMIC PEACE. The Polity Project, 2016. Disponível em http://www.systemicpeace.org/polityproject.html Acesso em 10 de dezembro de 2016.

CES. Relatório da Reunião Ajuda Internacional e Construção da Paz em Angola realizada em Luanda em 2007. Disponível em http://www.ces.uc.pt/nucleos/nep/pdfs/pagina4_link2.pdf Acesso em 05 de janeiro de 2016.

CHABAL, Patrick, et al. A History of Postcolonial Lusophone Africa. Londres \& Indianapolis: Hurst \& Indiana University Press, 2002.

CHABAL, Patrick. The Transition to Multi-Party Politics in Lusophone Africa: Problems and Prospects. Lusotopie, pp. 57-69, 1996. Disponível em http://lusotopie.sciencespobordeaux.fr/chabal96.pdf Acesso em 05 de janeiro de 2017.

CIA (CENTRAL InTElligenCE AGENCY). The World Fact Book, 2017. Disponível em https://www.cia.gov/library/publications/resources/the-world-factbook/ Acesso em 05 de janeiro de 2017.

CITI, 2016. Guerra Colonial. Centro de Investigação para Tecnologias Interativas (CITI). Faculdade de Ciências Sociais e Humanas, Universidade Nova de Lisboa, Portugal, 2016.2 Disponível em http://www.citi.pt/cultura/politica/25_de_abril/guerra_colonial.html Acesso em 05 de janeiro de 2016.

COLLIER, David. "The Comparative Method", in Ida W. Finifter (ed.), Political Science: The State of the Discipline II. Washington, D. C.: American Political Science Association, 1993.

COUNCIL ON FOREIGN RELATIONS (CFR). The Relationship between Democracy and Development: Implications for Policy. March $19^{\text {th }}$ 2013. Disponível em http://www.cfr.org/democratization/relationship-between-democracy-developmentimplications-policy/p5778 Acesso em 05 de janeiro de 2017.

DAHL, Robert. Polyarchy: Participation and Opposition. New Haven: Yale University Press, 1972. 
DATASUS. Indicadores e Dados Básicos - Brasil, 2012. Disponível em http://tabnet.datasus.gov.br/cgi/idb2012/matriz.htm Acesso em 5 de dezembro de 2016.

DESCHOUWER, Kris. Comparative Analysis: Talking about Apples and Oranges. Vrije Universiteit Brussel, 2016. Disponível em http://www.ies.be/files/IES\%20Kris\%20Deschouwer.pdf Acesso em 05 de janeiro de 2017.

DIAMOND, Larry. Developing Democracy: Toward Consolidation. Baltimore: Johns Hopkins University Press, 1999.

DITRICH, Simone; WRIGHT, Joseph. Foreign Aid Allocation Tactics and Democratic Change in Africa. The Journal of Politics, 2015. Disponível em http://simonedietrich.com/content_images/file/JOP\%20Final\%20MS+App\%20+url.pdf Acesso em 25 de maio de 2015.

DOYLE, Michael. Liberalism and the end of the cold war. In: Richard N. Lebow \& Thomas Risse-Kappen, International Relations Theory and the End of the Cold War. New York: Columbia University Press, 1995.

Promoting Democracy is not imposing Democracy. The Huffington Post, 2011. Disponível em <http://www.huffingtonpost.com/michael-doyle/promotingdemocracy-is-no_b_826574.html>. Acesso em 13 de março de 2015.

ÉVORA, Roselma. A abertura política e processo de transição democrática em CaboVerde. Dissertação de mestrado. Brasília, Universidade de Brasília, 2001.

ESPÍRITO SANTO, Armindo. Reflexão sobre bloqueios ao desenvolvimento no período pós-independência in Olhares Cruzados sobre a Economia de São Tomé e Príncipe. Edições Colibri e Universidade Lusíada de São Tomé e Príncipe: Lisboa, $2013 a$.

Abertura ao exterior: uma inevitabilidade para as pequenas economias insulares e condição essencial para o desenvolvimento sustentável de São Tomé e Príncipe in Olhares Cruzados sobre a Economia de São Tomé e Príncipe. Edições Colibri e Universidade Lusíada de São Tomé e Príncipe: Lisboa, 2013b.

EPORTUGUESE. As origens e a evolução étnico-cultural dos PALOP - Angola e Cabo Verde. EPortuguese - Organização Mundial da Saúde, 2011a. Disponível em http://eportuguese.blogspot.com.br/2011/08/as-origens-e-evolucao-etnico-cultural.html Acesso em 10 de janeiro de 2017.

As origens e a evolução étnico-cultural dos PALOP - Moçambique e São Tomé e Príncipe. EPortuguese - Organização Mundial da Saúde, 2011b. Disponível em http://eportuguese.blogspot.com.br/2011/08/as-origens-e-evolucao-etnicocultural_22.html Acesso em 10 de janeiro de 2017.

As origens e a evolução étnico-cultural dos PALOP - Guiné-Bissau.

EPortuguese - Organização Mundial da Saúde, 2011b Disponível em http://eportuguese.blogspot.com.br/2011/08/as-origens-e-evolucao-etnico-

cultural_14.html Acesso em 10 de janeiro de 2017. 
FERREIRA, Eduardo. Portuguese Colonialism in Africa, the End of na Era: The effects of Portuguese Colonialism on Education, Science, Culture and Information. Paris: The UNESCO Press, 1974. Disponível em http://unesdoc.unesco.org/images/0001/000113/011345eo.pdf Acesso em 5 de dezembro de 2016.

FISH, Steven; KROENIG, Matthew. Diversity, Conflict and Democracy: Some Evidence from Eurasia and East Europe, Democratization, 13 (5): 828-42, 2006.

FORTUNA, Carlos. Descolonização, o Fim de um Ciclo: Portugal, a África e a Economia Capitalista Mundial. Revista Crítica de Ciências Sociais, 15/16/17 (1985) 469-499, Maio de 1985.

FRAGA, Alves. Guerra colonial: 1961-1974. 2014. Camões - Repositório Institucional da Universidade Autônoma de Lisboa, Departamento de Relações Internacionais, DRI Artigos/ Papers, 2014. Disponível em http://hdl.handle.net/11144/653 Acesso em 05 de dezembro de 2016.

FRANCO, A.; ÉLVAREZ-DARDET, C.; RUIZ, MT. Effect of democracy on health: ecological study. BMJ, 329: 1421-1423, 2004.

FREEDOM HOUSE. Freedom in the World 2015 - Interactive Map, 2015. Disponível em https://freedomhouse.org/report/freedom-world/freedom-world2015\#.WGLOrlMrLIU. Acesso em 30 de janeiro de 2017.

Freedom in the World 2016, 2016. Disponível em http://www.freedomhouse.org/report/freedom-world/freedom-world2014\#.VEcOifnF8uc. Acesso em 21 de maio de 2016.

Freedom in the World 2017, 2017. Disponível em https://freedomhouse.org/report/freedom-world/freedom-world-2017. Acesso em 05 de janeiro de 2017.

Freedom in the World 2017: Mozambique, 2017a. Disponível em https://freedomhouse.org/report/freedom-world/2016/mozambique. Acesso em $01 \mathrm{de}$ fevereiro de 2017.

FOUNDATION FOR THE DEFENSE OF DEMOCRACIES. Cape Verde: A Rare African Success. 20 de fevereiro de 2008. Disponível em http://www.defenddemocracy.org/media-hit/cape-verde-a-rare-african-success/ Acesso em 05 de janeiro de 2017.

FUKUYAMA, F. 1995. The end of History. In: Conflict after the Cold War: Arguments on causes of war and peace, edited by Richard Beets, 85-108. New York: Macmillan Press, 1995.

GAMA, Flávio A. São Tomé e Príncipe. African Economic Outlook 2014. Disponível em 
http://www.africaneconomicoutlook.org/fileadmin/uploads/aeo/2014/PDF/CN_Long_P T/Sao_Tome_et_Principe_PT_BAT.pdf Acesso em 05 de janeiro de 2017.

GASIOROWSKI, Mark; POWER, Timothy. The Structural Determinants of Democratic Consolidation: Evidence from the Third World. Comparative Political Studies, vol. $31 \mathrm{n}^{\mathrm{o}}$ 6, December 1998.

GIG. Transparência da Ajuda Externa e do Orçamento em Moçambique. Grupo Informal de Governação (GIG) e Aliança 2015, 2010. Disponível em http://www.trocaire.org/sites/trocaire/files/resources/policy/aid-budget-transparencymozambique-portuguese.pdf Data de acesso: 20 de maio de 2015. Acesso em 05 de janeiro de 2017.

GLOBO. Angola, independência e guerra civil após quatro séculos de domínio português. Publicado em 23 de setembro de 2013. Disponível em http://acervo.oglobo.globo.com/fatos-historicos/angola-independencia-guerra-civilapos-quatro-seculos-de-dominio-portugues-10110726 Acesso em 5 de janeiro de 2017.

GOLVEIA, José Gregório. Guiné-Bissau de Colônia a Independente. CART 1525, 2010. Disponível em http://www.cart1525.com/gouveia/independencia.pdf Acesso em 05 de janeiro de 2017.

GOLVEIA, Helena; KRIEGER, Renate. O massacre esquecido de Angola. DW, 9 de junho de 2011. Disponível em http://dw.com/p/RSks_Acesso em 05 de janeiro de 2017.

GOVERnO DE CABO VERDE. História de Cabo Verde, site do Governo de Cabo Verde, 2016. Disponível em www.governo.cv Acesso em 08 de novembro de 2016.

GUGLIANO, Alfredo. Apontamentos sobre o conceito de qualidade da democracia. Revista Debates, Porto Alegre, v.7, n.1, jan.-abr. 2013. Disponível em http://seer.ufrgs.br/debates/article/viewFile/36918/24047 Acesso em 25 de maio de 2015.

GUO, Sujian. Democratic Transition: A Critical Overview. Issues \& Studies 35, $\mathrm{n}^{\mathbf{o}} 4$, julho/agosto, $1999 . \quad$ Disponível em http://online.sfsu.edu/sguo/My\%20articles/Democratic\%20Transition_1999_35_4.pdf Acesso em 25 de maio de 2016.

HENRIQUE, Joana G; BATISTA, Frederico. Cabo Verde: O país que tem mais gente fora do que dentro. Público, Portugal, 5 de julho de 2015. Disponível em https://www.publico.pt/mundo/noticia/o-pais-que-tem-mais-gente-fora-do-que-dentro1700904 Acesso em 05 de janeiro de 2016.

HORING, Jessica. Os Movimentos de Libertação Nacional em Angola: Trajetória Política, Guerra Civil e Impactos sobre a Construção do Estado (1975-2002). Trabalho de Conclusão de Curso em Relações Internacionais, Faculdade de Ciências Econômicas, Universidade Federal do Rio Grande do Sul. Porto Alegre, 2015. 
HUNTINGTON, Samuel, "Democracy's Third Wave", in Larry Diamond and Marc F. Plattner (Eds), The Global Ressurgence of Democracy, 2nd Ed., Baltimore and London: The John Hopkins Press, 1996.

S. The errors of endism. In: The New Shape of world Politics: Contending Paradigms in International Relations. New York: Foreign Affairs Agenda Series, 1997. 35-49, 1999. The Lonely Superpower. Foreign Affairs, vol. 78, n.02, Mar/Apr.1999, p. The Neoidealist Moment in International Studies? Realist Myths and the New International Realities. International Studies Quartely, vol. 37, n², pp.131-146, 1993.

IBRAHIM INDEX OF AFRICAN GOVERNANCE (IIAG). Governance in Angola, Cabo Verde, Guinea-Bissau, Mozambique and Sao Tome \& Principe. Disponível em http://iiag.online/ Acesso em 05 de janeiro de 2017.

INGLEHART, Ronald; WELZEL, Christian. How Development Leads to Democracy: What We Know About Modernization. Foreign Affairs, vol, 88, n. 02, pp. 33-48, 2009.

IDEA. Democracy, Natural Resources and Development. Institute for Democracy and Electoral Assistance (IDEA), 2016. Disponível em http://www.oldsite.idea.int/development/democracy-natural-resources-anddevelopment.cfm Acesso em 05 de janeiro de 2017.

IZERROUGENE, Bouzid; MATA, Henrique. Reflexões teóricas sobre economia do desenvolvimento de São Tomé e Príncipe in Olhares Cruzados sobre a Economia de São Tomé e Príncipe. Edições Colibri e Universidade Lusíada de São Tomé e Príncipe: Lisboa, 2013.

JAFAR, Silvestre. Análise Sócio-histórica sobre a Guerra Civil em Moçambique 1976 - 1992: Uma Abordagem Holística. ICS Working Papers 6. Instituto de Ciências Sociais, Universidade de Lisboa, 2014. Disponível em http://www.ics.ul.pt/publicacoes/workingpapers/wp2014/wp2014_6.pdf Acesso em 05 de janeiro de 2017.

JENSEN, Nathan; WANTCHEKON, Leonard. Resource Wealth and Political Regimes in Africa. Comparative Political Studies, 37 pp. 816-841, 2004.

JOSÉ, Joveta. Política Externa de Angola de 1992 aos dias atuais. In: $33^{\circ}$ Encontro Anual da ANPOCS. GT 19: Entre Fronteiras e Disciplinas: Estudos sobre África e Caribe. 2009.

Disponível

em

<http://portal.anpocs.org/portal/index.php?option=com_docman\&task=doc_view\&gid= 1977\&Itemid=229 Data de acesso 21 de maio de 2015. 
KAPFER, Steve; NIELSEN, Rich; NIELSON, Daniel. If you build it, will they come? Foreign Aid's effects on Foreign direct investment. $65^{\text {th }}$ MPSA National conference, $2007 . \quad$ Disponível em https://www.wm.edu/offices/itpir/_documents/aiddata/if_you_build_it_2007.pdf Acesso em 20 de maio de 2015.

KNACK, Stephen. 2003. Does Foreign Aid Promote Democracy? International Studies Quarterly, Vol. 48, No. 1. Mar., 2004.

KOUDAWO, Fafali. Cabo Verde e Guiné-Bissau: da Democracia Revolucionária à Democracia Liberal. Bissau, INEP, 2001.

KPUNDEH. Sahr (ed.). Democratization in Africa: African Views, African Voices. National Academy Press, Washington, DC., 1992.

LAWSON, Chapel. MIT OpenCourseWare course materials for 17.50 Introduction to Comparative Politics, Fall, 2006, Massachusetts Institute of Technology. Disponível em <http://ocw.mit.edu/index.html> Acesso em 30 de maio de 2015.

LIMA, Adalberto de; GONCALVES, Carlos Eduardo. Determinantes da democracia: novos olhares sobre um velho debate. Rev. Bras. Econ., Rio de Janeiro, v. 65, n. 4, p. 341-346, Dec. 2011 Available from $<$ http://www.scielo.br/scielo.php?script=sci_arttext\&pid=S0034-

$71402011000400001 \& \operatorname{lng}=\mathrm{en} \& \mathrm{nrm}=\mathrm{iso}>$. access on 05 Jan. 2017. http://dx.doi.org/10.1590/S0034-71402011000400001.

LINZ, J.J.; STEPAN, A. Problems of democratic transition and consolidation. Baltimore: Johns Hopkins University Press, 1996.

LIJPHART, Arend. Comparative Politics and the Comparative Method. American Political Science Review, vol. 65, September 1971

LIPSET, Seymour M. Some Social Requisites of Democracy: Economic Development and Political Legitimacy. The American Political Science Review. Vol. 53, No. 1, $p$. 69-105, Mar., 1959.

. American Exceptionalism: A Double-Edged Sword. New York: W.W. Norton \& Company. 1997.

LOPES, Nelson. Os Entraves à Construção e Consolidação do Estado da GuinéBissau. CIEA7 \#34, $7^{\circ}$ Congresso Ibérico de Estudos Africanos. Lisboa, 2010. Disponível em file:///C:/Users/tdeol/Desktop/GB2\%20p7.pdf Acesso em 05 de janeiro de 2017.

MACUANE, José Jaime. Liberalização política e democratização na África: uma análise qualitativa. Dados, Rio de Janeiro , v. 43, n. 4, 2000 . Disponível em <http://www.scielo.br/scielo.php?script=sci_arttext\&pid=S001152582000000400003\&lng=en\&nrm=iso>. Data de acesso: 13 de maio de 2015. 
McFAUL, Michael. The Fourth Wave of Democracy and Dictatorship: Noncooperative Transitions in the Postcommunist World, World Politics 54: 212244, 2002.

MEYNS, Peter. Cape Verde: An African Exception. Journal of Democracy, vol. 13, n. 3, pp. 153-165, 2002.

MIA COUTO. Entrevista no documentário Independência e Morte: a África Portuguesa, TV BRASIL, 26 de junho de 2015. Disponível em https://www.youtube.com/watch?v=GywWEuE0Y_k Acesso em 05 de janeiro de 2017.

MINILLO, Xaman. A importância do estudo das Relações Internacionais Africanas para o Campo das Relações Internacionais. Revista Monções: Vol. 1 n. 1 - UFGD - Jan/Jun 2012. 157, 2012.

MOITA, Luis. Os Congressos da FRELIMO, do PAIGC e do MPLA: uma análise. Lisboa: Ulmeiro, 1979.

MOLLER, Jorgen. The gap between liberal and electoral democracy revisited. Some conceptual and empirical clarifications. EUI Working Paper SPS, 2006. Disponível em http://cadmus.eui.eu/bitstream/handle/1814/4204/WPSPSMoller2006.01.pdf?sequence= 1 Acesso em 1 de junho de 2015.

MOORE, Mick. Natural Resource Wealth is Bad for Democracy. Governance and Development Review, 2001. Disponível em http://www2.ids.ac.uk/gdr/reviews/review03.html Acesso em 05 de janeiro de 2017.

MOSCA, João. Encruzilhadas de África: Ênfase para os PALOP. Lisboa: Instituto Piaget, 2001.

MUEKALIA, Jardo. Angola: A Segunda Revolução. Lisboa: Sextante Editora, 2013.

MURTIN, Fabrice; WACKZIARG, Romain. The Democratic Transition. Journal of Economic Growth, 19 (2), junho, 2014. Disponível em < $<$ http://www.anderson.ucla.edu/faculty_pages/romain.wacziarg/downloads/transition.pd f> Acesso em 30 de maio de 2015.

NATURAL RESOURCES GOVERNANCE INSTITUTE. Natural Resources, Representative Democracy and Development: What Role for Political Parties? November $18^{\text {th }}, 2015$. Disponível em http://www.resourcegovernance.org/blog/naturalresources-representative-democracy-and-development-what-role-political-parties Acesso em 05 de janeiro de 2017.

PACHECO, Carlos. Angola: Um gigante com pés de barro. Lisboa: Editora Nova Vega, $4^{\mathrm{a}}$ edição, 2014.

PAREDES, Marçal. A construção da identidade nacional moçambicana no pósindependência: sua complexidade e alguns problemas de pesquisa. Anos 90, Porto Alegre, v. 21, n. 40, p. 131-161, dez. 2014. 
PENNA FILHO, Pio. Entrevista no documentário Independência e Morte: a África Portuguesa, TV BRASIL, 26 de junho de 2015. Disponível em https://www.youtube.com/watch?v=GywWEuE0Y_k Acesso em 05 de janeiro de 2017.

PEREIRA, Daniel. Um olhar sobre Cabo Verde: História para Jovens. Brasília: Thesaurus, 2013.

PINTO, António Costa. O Fim do Império Português - a Cena Internacional, a Guerra Colonial e a Descolonização, 1961 - 1974. Lisboa: Livros Horizonte, 2001.

PETERS, Hanah et al. Effect of democratic reforms on child mortality: a synthetic control analysis. The Lancet Global Health, v. 4, n. 9, pp. 627 - 632, September 2016.

PIRAGIBE, Clélia Virgínia Santos. A participação brasileira na construção da paz em Guiné-Bissau. Boletim Meridiano 47, [S.1.], v. 15, n. 146, p. 27-34, dec. 2014. ISSN 1518-1219. Disponível em: http://periodicos.unb.br/index.php/MED/article/view/12399. Acesso em 05 de janeiro de 2017.

PNUD. Human Development Data (1980-2015). United Nations Development Programme - Human Development Reports, 2016. Disponível em http://hdr.undp.org/en/data Acesso em 05 de janeiro de 2017.

PRZEWORSKI, Adam. 2004. Democracy and Economic Development in Edward D. Mansfield and Richard Sisson (eds.) The Evolution of Political Knowledge. Columbus: Ohio State University Press, 2004.

PRZEWORSKI, Adam; et al. Democracy and Development: Political Institutions and Well-Being in the World, 1950-1990. Cambridge: Cambridge University, 2000.

PRZEWORSKI, Adam; TEUNE, Henry. The Logic of Comparative Social Inquiry. $\begin{array}{llllll}\text { New } & \text { York: Wiley } & \text { J } & \end{array}$

POLITY IV. Polity IV Individual Country Regime Trends, 1946-2013, 2016. Disponível em http://www.systemicpeace.org/polity/polity4.htm Acesso em 15 de maio de 2016.

POLITY IV. Authority Trends, 1975-2013: Cape Verde. Polity IV, 2016a. Disponível em http://systemicpeace.org/polity/cap2.htm Acesso em 15 de maio de 2016.

POLITY IV. Authority Trends, 1975-2013: Mozambique. Polity IV, 2016b. Disponível em http://systemicpeace.org/polity/mzm2.htm Acesso em 15 de maio de 2016.

POLITY IV. Authority Trends, 1975-2013: Guinea-Bissau. Polity IV, 2016c. Disponível em http://systemicpeace.org/polity/gnb2.htm Acesso em 15 de maio de 2016.

POLITY IV. Authority Trends, 1975-2013: Angola. Polity IV, 2016d. Disponível em http://systemicpeace.org/polity/ang2.htm Acesso em 15 de maio de 2016. 
POLITY IV REPORT. Polity IV Country Report 2010 Series - Explanatory Notes, 2016. Disponível em http://www.systemicpeace.org/polity/keynew.htm Acesso em 10 de dezembro de 2016.

QUEIROZ, Thaís de O. A exportação da democracia liberal pelo uso da força: uma análise comparada dos casos da Alemanha, Japão, Afeganistão e Iraque. Agosto de 2012. Dissertação de Mestrado. Instituto de Relações Internacionais, Universidade de Brasília. Brasília, 2012.

QUEIROZ, Thais de Oliveira; BRITTO, Andrea Fernanda Rodrigues. A Democracia como Objeto de Análise na Teoria das Relações Internacionais no Pós-Guerra Fria. Boletim Meridiano 47, [S.1.], v. 16, n. 147, p. 11-18, mar. 2015. ISSN 1518-1219. Disponível em: <http://periodicos.unb.br/index.php/MED/article/view/12242>. Data de acesso: 13 de maio de 2015

RAMOS, Maria da Luz. Os Cabo-Verdianos e a Democracia: Uma análise das perspectivas e atitudes dos cidadãos. Atas do Colóquio Internacional Cabo-Verde e Guiné-Bissau: Percursos do Saber e da Ciência. Lisboa, junho de 2012. Disponível em https://coloquiocvgb.files.wordpress.com/2013/06/p03c04-maria-da-luz-ramos.pdf Acesso em 5 de outubro de 2016.

RESNICK, Danielle. Foreign Aid in Africa. World Institute for Development Economics Research. Working Paper $n^{\mathbf{o}}$ 2012/15, 2012. Disponível em http://www.wider.unu.edu/stc/repec/pdfs/wp2012/wp2012-015.pdf Acesso em 15 de maio de 2015.

REZENDE, Flávio da Cunha. Razões emergentes para a validade dos estudos de caso na ciência política comparada. Revista Brasileira de Ciência Política, Brasília, n. 6, p. 297-337, Dec. 2011. Disponível em <http://www.scielo.br/scielo.php?script=sci_arttext\&pid=S010333522011000200012\&lng=en\&nrm=iso >. Data de acesso: 13 de maio de 2015.

RFI. Adama Barrow é o novo Presidênte da Gâmbia. RFI - As Vozes do Mundo, 12 de dezembro de 2016. Disponível em http://pt.rfi.fr/africa/20161202-adama-barrow-e-onovo-presidente-da-gambia Acesso em 05 de janeiro de 2017.

RICH, Thimothy. Island Microstates and Political Contention: An Exploratory Analysis of Cape Verde and Comoros. African and Asian Studies, Volume 7, 2008, pp. 217-233. Disponível em http://timothysrich.com/documents/Island_Microstates_and_Political_Contention.pdf Acesso em 05 de janeiro de 2016.

RODRIGUES, Cristina. Pobreza em Angola: efeito da guerra, efeitos da paz. Revista Angolana de Sociologia (RAS), nº 9, p. 113-123, 2012.

ROSS, Michael. Does Oil Hinder Democracy? World Politics, vol. 53, n. 3, pp. 325-61, April 2001. 
RTC. 13 de Janeiro: Dia da Liberdade e da Democracia. Rádio Televisão Caboverdiana (RTC), 13 de janeiro de 2010. Disponível em http://www.rtc.cv/index.php?paginas=21\&id_cod=200 Acesso em 05 de janeiro de 2017.

RUSTOW, Dankwart. Transitions to Democracy: Toward a Dynamic Model, in ANDERSON, Lisa, ed. Transitions to Democracy. New York, Columbia University Press, 1999.

SANGREMAN, C. et al. A evolução Política Recente na Guiné-Bissau. Coleção Documentos de Trabalho, $\mathrm{n}^{\circ}$ 70. Lisboa: Centro de Estudos Sobre África e do Desenvolvimento do Instituto Superior de Economia e Gestão da Universidade Técnica de Lisboa, 2006.

SARAIVA, J. F. S. A África no século XXI: Um ensaio acadêmico. 1. ed. Brasília: Fundação Alexandre de Gusmão - FUNAG, 2015.

. A África na ordem internacional do século XXI: mudanças epidérmicas ou ensaios de autonomia decisória? Revista Brasileira de Política Internacional, v. 51, p. 105-122, 2008.

Formação da África Contemporânea. 1. ed. São Paulo: ATUAL, 1987.

SARTORI, Giovanni. Compare Why and How. Comparing, Miscomparing and the Comparative Method, Mattei Dogan \& Ali Kazancigil (eds.), Comparing Nations. Concepts, Strategies, Substance. Oxford UK \& Cambridge MA: Blackwell, 1994, pp. 14-34.

SCHATZBERG, Michael. Power, Legitimacy and Democratisation in Africa. Africa, Vol. 63, No. 4, 1993.

SCHDLER, Andreas. Concepts of Democratic Consolidation. Latin America Studies Association, 1997. Disponível em http://lasa.international.pitt.edu/LASA97/schedler.pdf Acesso em 20 de maio de 2015.

SCHMITTER, Philippe. Democratization and Political Elites. European University Institute, $2016 . \quad$ Disponível em http://www.eui.eu/Documents/DepartmentsCentres/SPS/Profiles/Schmitter/DEMOCRA TIZATION-AND-POLITICAL-ELITES.REV.pdf Acesso em 05 de janeiro de 2016.

SCHNEIDER, Carsten; SCHMITTER, Philippe. Liberalization, Transition and Consolidation: Measuring the Components of Democratization. Democratization, vol. 11, n. 05, 2004.

SHARE, Donald \& MAINWARING, Scott. Transições através da Negociação: a Democratização no Brasil e na Espanha. Dados, vol. 29, n. 02., 1986.

SNYDER, J. One World, Rival Theories. Foreign Policy, nov-dec. pp. 52-62, 2004. 
SODERBERG, Mimmi; OHLSON, Thomas. Democratisation and Armed Conflicts in Weak states. Swedish International Development Cooperation Agency: Stockholm, 2003.

SOUSA, Jorge Pais. O Estado Novo de Salazar como um Fascismo de Cátedra: Fundamentação histórica de uma categoria política. Storicamente, vol. 5, 2009. Disponível

$\mathrm{em}$ https://estudogeral.sib.uc.pt/bitstream/10316/11859/1/O\%20Estado\%20Novo\%20de\%2 0Salazar\%20como\%20um\%20fascismo\%20de\%20c\%C3\%A1tedra.pdf Acesso em 05 de dezembro de 2016.

STRADIOTTO, Gary; GUO, Sujian. Transitional Modes of Democratization and Democratic Outcomes. International Journal on World Peace, volume XXVII, $\mathrm{n}^{\mathbf{0}}$ 4, dezembro de 2010. Disponível em http://online.sfsu.edu/sguo/My\%20articles/Democratic\%20transition_proofs_IJWP.pdf Acesso em 30 de maio de 2015.

TAIMO, Jamisse U. Ensino Superior em Moçambique: história, política e gestão. Piracicaba: Universidade Metodista de Piracicaba, 2010, Tese de Doutorado.

TEACHING COMPARATIVE. Democracy spreads because of its virtues. Right? 2013. Disponível em http://compgovpol.blogspot.com.br/2013/12/democracy-spreadsbecause-of-its.html Acesso em 1 de junho de 2015.

TESSADORI, Pietro. África nos regimes fascista italiano e autoritário português. Locus: Revista de História, Juiz de Fora, v. 18, nº 1, pp. 111-122, 2012.

TONIZZO, Martina. Political Institutions, Size of Government and Redistribution: An Empirical Investigation. LSE Working Paper Series, 2008. Disponível em http://www.lse.ac.uk/internationalDevelopment/pdf/WP/WP89.pdf Acesso em 25 de maio de 2015.

TV BRASIL. Independência e Morte: a África Portuguesa, TV BRASIL, 26 de junho de 2015. Disponível em https://www.youtube.com/watch?v=GywWEuE0Y_k Acesso em 05 de janeiro de 2017.

TV ZIMBO, 2009. Morreu Nino Vieira (I). 3 de março de 2009. Disponível em https://www.youtube.com/watch?v=F9At9jIzUp0 Acesso em 30 de janeiro de 2007.

VALENZUELA, J. S. Democratic Consolidation in Post-Transitional Settings: Notions, Process and Facilitating Conditions. In Mainwaring, S., O’Donnell, G. e Valenzuela J.S. (eds.). Issues in Democratic Consolidation: The New South American Democracies in Comparative Perspective. Notre Dame, Indiana: The Notre Dame University Press, 1992.

VEIGA, Abel. Pinto avançou para a democracia contra a vontade dos líderes de outros PALOP. Télanón - Notícias de São Tomé e Príncipe. Disponível em http://www.telanon.info/politica/2014/08/13/17132/pinto-avancou-sozinho-para-ademocracia-pluralista-contra-vontade-dos-lideres-de-outros-palop/ Acesso em 20 de maio de 2016. 
VICENTE LOPES, José. Entrevista no documentário Independência e Morte: a África Portuguesa, TV BRASIL, 26 de junho de 2015. Disponível em https://www.youtube.com/watch?v=GywWEuE0Y_k Acesso em 05 de janeiro de 2017.

VON LAER, Wolf. Small Is Beautiful: The Democratic Advantages of Smaller States. The Huffington Post, 30 de abril de 2015. Disponível em http://www.huffingtonpost.com/st-gallen-symposium/small-is-beautiful-thede_b_7178640.html Acesso em 05 de janeiro de 2017.

V-DEM. Variables of Democracy: Graphs. Disponível em https://www.vdem.net/en/analysis/CountryGraph/ Acesso em 05 de janeiro de 2017.

WIARDA, Howard J. Introduction to Comparative Politics. Fort Worth, TX: Harcort Brace/ Wadsworth, 2000.

WHITEHEAD, Laurence. Theory and Experience. Oxford: Oxford University Press, 2002.

. Geography and Democratic Destiny. Journal of Democracy, vol. 10, n. 01, pp. 74-79, January, 1999.

$\begin{array}{lcrrr}\text { WORLDWIDE } & \text { GOVERNANCE } & \text { INDICATORS. } & \text { The } & \text { Worldwide } \\ \text { Indicators } & \text { (WGI) } & \text { Project. } & \text { Disponível } & \text { em }\end{array}$ http://info.worldbank.org/governance/wgi/index.aspx\#home Acesso em 05 de janeiro de 2017.

ZECA, Emilio. Moçambique: Exploração de Recursos, Privação Relativa e Segurança. Centro de Estudos Estratégicos e Internacionais. Ano I, Série de Artigos n. 01, abril de 2013. Maputo, Moçambique. Disponível em http://www.academia.edu/8919894/Mo\%C3\%A7ambique_Explora\%C3\%A7\%C3\%A3 o_de_Recursos_Priva\%C3\%A7\%C3\%A3o_Relativa_e_Seguran\%C3\%A7a Acesso em 05 de janeiro de 2017.

\section{Documentos primários:}

Ato Colonial: Decreto-Lei No .22 .465 de 11 de Abril de 1933.

CONSTITUIÇÃO DA REPÚBLICA DE ANGOLA. Assembleia Nacional: Luanda, 2010. Disponível em http://angolaembassy.org.il/documents/AngolaConstitution05.02.2010.pdf Acesso em 05 de janeiro de 2017.

CONSTITUIÇÃO DA REPÚBLICA DE CABO VERDE. Assembleia Nacional: Praia, 1992. Disponível em http://www.ucp.pt/site/resources/documents/IEP/LusoForum/constituicao\%20cape\%20 verde.pdf Acesso em 05 de janeiro de 2017. 
CONSTITUIÇÃO DA REPÚBLICA DE MOÇAMBIQUE. Assembleia da República de Moçambique: Maputo, 1994. Disponível em

http://publicofficialsfinancialdisclosure.worldbank.org/sites/fdl/files/assets/law-libraryfiles/Mozambique_Constitution_1990_(as\%20amended)_pt.pdf Acesso em 05 de janeiro de 2017.

CONSTITUIÇÃO DA REPÚBLICA DE GUINÉ-BISSAU. Assembleia Nacional Popular: Bissau, 1996. Disponível em

http://www.anpguinebissau.org/leis/constituicao/constituicaoguine.pdf Acesso em 05 de janeiro de 2017.

CONSTITUIÇÃO DA REPÚBLICA DE SÃO TOMÉ E PRÍNCIPE. Assembleia Nacional, 1993. Disponível em

http://www.asg.plp.org/upload/cadernos_tematicos/doc_139.pdf Acesso em 05 de janeiro de 2017. 


\section{ANEXO A - RESULTADOS DA DEMOCRATIZAÇÃO PELO USO DA FORÇA NA ALEMANHA, JAPÃO, AFEGANISTÃO E IRAQUE (QUEIROZ, 2012)}

\begin{tabular}{|c|c|c|c|c|}
\hline & Alemanha & Japão & Afeganistão & Iraque \\
\hline $\begin{array}{l}\text { Antecedentes } \\
\text { históricos }\end{array}$ & $\begin{array}{l}\text { Unificação } \\
\text { ocorrida em } 1871 \\
\text { por Bismarck, o } \\
\text { que fez com que o } \\
\text { Estado fosse forte } \\
\text { e consolidado no } \\
\text { momento da } \\
\text { intervenção norte- } \\
\text { americana. }\end{array}$ & $\begin{array}{l}\text { Estado forte e } \\
\text { consolidado, no } \\
\text { qual as dinastias } \\
\text { imperiais } \\
\text { lideravam um } \\
\text { governo histórico } \\
\text { por séculos. }\end{array}$ & $\begin{array}{l}\text { Estado vulnerável } \\
\text { e considerado por } \\
\text { alguns autores } \\
\text { como falido antes } \\
\text { da intervenção } \\
\text { norte-americana. }\end{array}$ & $\begin{array}{l}\text { Estado vulnerável e } \\
\text { fragilizado no que } \\
\text { tange à definição } \\
\text { westfaliana de } \\
\text { Estado nacional. }\end{array}$ \\
\hline $\begin{array}{c}\text { Experiência } \\
\text { democrática } \\
\text { anterior }\end{array}$ & $\begin{array}{l}\text { Sufrágio } \\
\text { masculino direto } \\
\text { para as eleições do } \\
\text { Reichstag durante } \\
\text { o Império } \\
\text { Alemão. } \\
\text { Instauração da } \\
\text { República de } \\
\text { Weimar, após a } \\
\text { Primeira Guerra } \\
\text { Mundial. }\end{array}$ & $\begin{array}{l}\text { Nova estruturação } \\
\text { do } \\
\text { realizada } \\
\text { Rstado } \\
\text { Revolução Meiji, } \\
\text { bem como o } \\
\text { período situado } \\
\text { entre 1910 e 1920, } \\
\text { referente } \\
\text { "Democracia a } \\
\text { Taisho". }\end{array}$ & Não houve. & Não houve. \\
\hline $\begin{array}{c}\text { Diversidade } \\
\text { étnica, religiosa e } \\
\text { cultural }\end{array}$ & $\begin{array}{lr}\text { A maioria } & \text { da } \\
\text { população } & \text { era } \\
\text { formada } & \text { por } \\
\text { arianos } & \\
\text { protestantes } & \text { e } \\
\text { católicos } & \end{array}$ & $\begin{array}{l}\text { A população é } \\
\text { muito homogênea, } \\
\text { dividindo-se no } \\
\text { âmbito religioso, } \\
\text { primordialmente, } \\
\text { entre budistas e } \\
\text { xintoístas. }\end{array}$ & $\begin{array}{l}\text { Etnicamente, a } \\
\text { população é muito } \\
\text { heterogênea. No } \\
\text { aspecto religioso, } \\
80 \% \text { são sunitas, } \\
19 \% \text { xiitas, e } 1 \% \\
\text { pertence a outras } \\
\text { religiões. }\end{array}$ & $\begin{array}{l}\text { Sociedade dividida } \\
\text { principalmente } \\
\text { entre sunitas, xiitas } \\
\text { e curdos. }\end{array}$ \\
\hline $\begin{array}{c}\text { Desenvolvimento } \\
\text { econômico antes } \\
\text { da intervenção } \\
\text { norte-americana }\end{array}$ & $\begin{array}{l}\text { Possuía grande } \\
\text { potencial } \\
\text { econômico, } \\
\text { devido à intensa } \\
\text { industrialização } \\
\text { que vivenciou no } \\
\text { final do século } \\
\text { XIX durante o } \\
\text { Império Alemão, e } \\
\text { no período } \\
\text { anterior à guerra } \\
\text { (nazismo). }\end{array}$ & $\begin{array}{l}\text { Apresentava um } \\
\text { parque industrial } \\
\text { existente desde a } \\
\text { Revolução Meiji. }\end{array}$ & $\begin{array}{l}\text { A economia afegã } \\
\text { encontrava-se } \\
\text { devastada no } \\
\text { momento da } \\
\text { intervenção norte- } \\
\text { americana, e não } \\
\text { existia no país um } \\
\text { potencial de } \\
\text { desenvolvimento } \\
\text { industrial. A } \\
\text { economia estava } \\
\text { baseada } \\
\text { primordialmente } \\
\text { no cultivo da } \\
\text { papoula e na } \\
\text { agricultura } \\
\text { subsistência. de }\end{array}$ & $\begin{array}{l}\text { A economia do país } \\
\text { era baseada no } \\
\text { petróleo, e o país } \\
\text { não possuía um } \\
\text { parque industrial } \\
\text { que pudesse ser } \\
\text { impulsionado pelos } \\
\text { norte-americanos. }\end{array}$ \\
\hline $\begin{array}{c}\text { Desenvolvimento } \\
\text { econômico após }\end{array}$ & $\begin{array}{lr}\text { A economia alemã } \\
\text { já } & \text { estava } \\
\text { recuperada } & \text { em } \\
\end{array}$ & $\begin{array}{lr}\text { A } & \text { economia } \\
\text { japonesa já estava } \\
\text { recuperada } & \text { em } \\
\end{array}$ & $\begin{array}{l}\text { A economia afegã } \\
\text { encontrava-se em } \\
\text { colapso, com altas }\end{array}$ & $\begin{array}{lr}\text { Mesmo a situação } \\
\text { da } & \text { economia } \\
\text { iraquiana } & \text { se } \\
\end{array}$ \\
\hline
\end{tabular}




\begin{tabular}{|c|c|c|c|c|}
\hline $\begin{array}{c}\text { a intervenção } \\
\text { norte-americana }\end{array}$ & $\begin{array}{l}1952 \text { e } \\
\text { apresentava níveis } \\
\text { de comércio } \\
\text { internacional } \\
\text { superiores ao } \\
\text { período anterior à } \\
\text { Segunda Guerra } \\
\text { Mundial. }\end{array}$ & $\begin{array}{l}1952, \\
\text { aproximadamente } \\
\text { um ano antes de } \\
\text { completar a sua } \\
\text { transição } \\
\text { democrática. }\end{array}$ & $\begin{array}{lr}\text { taxas } & \text { de } \\
\text { desemprego, } & \\
\text { aumento } & \text { do } \\
\text { cultivo } & \text { da } \\
\text { papoula, } & \text { e } \\
\text { extrema } & \\
\text { dependência } & \text { da } \\
\text { ajuda } & \\
\text { internacional. } & \end{array}$ & $\begin{array}{l}\text { apresentando } \\
\text { relativamente } \\
\text { melhor do que a do } \\
\text { Afeganistão, as } \\
\text { melhorias } \\
\text { econômicas são } \\
\text { pouco significativas } \\
\text { quando comparadas } \\
\text { à fragilizada } \\
\text { economia existente } \\
\text { no governo de } \\
\text { Saddam Hussein. }\end{array}$ \\
\hline $\begin{array}{l}\text { Estabilidade } \\
\text { política antes da } \\
\text { intervenção } \\
\text { norte-americana }\end{array}$ & $\begin{array}{lr}\text { Poucos conflitos } \\
\text { violentos } & \text { de } \\
\text { contestação ao } \\
\text { governo de Hitler } \\
\text { e contra a } \\
\text { presença } \\
\text { estrangeira no país }\end{array}$ & $\begin{array}{l}\text { Inexistência de } \\
\text { revoltas populares } \\
\text { contra o } \\
\text { Imperador durante } \\
\text { o regime } \\
\text { monárquico, e } \\
\text { pouca resistência } \\
\text { à presença norte- } \\
\text { americana após } \\
\text { Segunda Guerra } \\
\text { Mundial. }\end{array}$ & $\begin{array}{l}\text { Cenário instável } \\
\text { de confrontos com } \\
\text { os Talibãs, que } \\
\text { ocupavam cerca } \\
\text { de } 95 \% \text { do país em } \\
2001 .\end{array}$ & $\begin{array}{lr}\text { Os conflitos entre o } \\
\text { governo de Saddam } \\
\text { Hussein } \\
\text { segmentos rebeldes } \\
\text { da população eram } \\
\text { recorrentes } \\
\text { violentamente } \\
\text { repreendidos. Os } \\
\text { curdos constituíam a } \\
\text { parcela rais } \\
\text { discriminada, sendo } \\
\text { a que mais entrava } \\
\text { em confronto com o } \\
\text { ditador. rar Eles } \\
\text { chegaram a ser } \\
\text { repreendidos com } \\
\text { armas químicas. }\end{array}$ \\
\hline $\begin{array}{c}\text { Estabilidade } \\
\text { política após da } \\
\text { intervenção } \\
\text { norte-americana }\end{array}$ & $\begin{array}{l}\text { Existiram alguns } \\
\text { focos de } \\
\text { resistência no } \\
\text { início da ocupação } \\
\text { norte-americana, } \\
\text { mas o resultado da } \\
\text { desnazificação foi } \\
\text { um sucesso. Os } \\
\text { confrontos entre } \\
\text { os alemães e os } \\
\text { estrangeiros foram } \\
\text { pouco } \\
\text { expressivos. }\end{array}$ & $\begin{array}{l}\text { A estabilidade } \\
\text { política no Japão } \\
\text { após a ocupação } \\
\text { dos norte- } \\
\text { americanos for } \\
\text { muito grande. O } \\
\text { general } \\
\text { MacArthur } \\
\text { utilizou para a } \\
\text { implantação da } \\
\text { democracia a a } \\
\text { mesma burocracia } \\
\text { estatal existente } \\
\text { no período } \\
\text { autoritário. } \\
\text { Apesar de } \\
\text { destituído do seu } \\
\text { caráter divino, o } \\
\text { Imperador } \\
\text { continuou } \\
\text { exercendo um } \\
\text { papel de destaque } \\
\text { no país. }\end{array}$ & $\begin{array}{l}\text { A Operação } \\
\text { Liberdade } \\
\text { Duradoura no } \\
\text { Afeganistão ainda } \\
\text { continua, e são } \\
\text { diariamente } \\
\text { observados muitos } \\
\text { conflitos entre os } \\
\text { cidadãos e os } \\
\text { norte-americanos. } \\
\text { Muitos que } \\
\text { acadêmicos } \\
\text { consideram que o } \\
\text { país se encontra } \\
\text { em um estado de } \\
\text { guerra civil. }\end{array}$ & $\begin{array}{l}\text { Após a intervenção } \\
\text { da coalizão, a } \\
\text { disputa pelo poder } \\
\text { iraquiano entre os } \\
\text { sunitas, xiitas e } \\
\text { curdos se tornou } \\
\text { intensa, } \\
\text { configurando-se } \\
\text { como um reflexo da } \\
\text { instabilidade } \\
\text { política da } \\
\text { sociedade, que se } \\
\text { apresenta dividida } \\
\text { em clivagens } \\
\text { sociais. Os conflitos } \\
\text { entre os civis e as } \\
\text { lideranças da } \\
\text { coalizão também se } \\
\text { intensificaram após } \\
\text { a ocupação. }\end{array}$ \\
\hline $\begin{array}{l}\text { Aceitação } \\
\text { popular do } \\
\text { regime } \\
\text { democrático }\end{array}$ & $\begin{array}{l}\text { A aceitação do } \\
\text { regime } \\
\text { democrático } \\
\text { imposto foi de } \\
\text { grande } \\
\text { intensidade, } \\
\text { resultando em } \\
\text { poucos conflitos }\end{array}$ & $\begin{array}{l}\text { A ocupação norte- } \\
\text { americana no } \\
\text { Japão foi menos } \\
\text { flexível do que na } \\
\text { Alemanha, mas } \\
\text { mesmo assim } \\
\text { apresentou um } \\
\text { caráter flexível, o }\end{array}$ & $\begin{array}{lr}\text { A } & \text { aceitação } \\
\text { popular } & \text { da } \\
\text { coalizão } & \text { no } \\
\text { Afeganistão } & \text { foi } \\
\text { muito } & \text { baixa, } \\
\text { causando } & \text { um } \\
\text { cenário de grande } \\
\text { instabilidade e de }\end{array}$ & $\begin{array}{l}\text { A aceitação popular } \\
\text { do regime } \\
\text { democrático foi } \\
\text { muito reduzida. A } \\
\text { instabilidade social } \\
\text { continuou e fatores } \\
\text { que interferem na } \\
\text { qualidade de vida, }\end{array}$ \\
\hline
\end{tabular}




\begin{tabular}{|c|c|c|c|c|}
\hline & $\begin{array}{lr}\text { entre o } & \text { governo } \\
\text { nacional } & \mathrm{e} \\
\text { população. } & \mathrm{a} \\
\text { ocupação } & \text { norte- } \\
\text { americana } & \text { foi } \\
\text { tolerante } & \mathrm{e} \\
\text { flexível. } & \end{array}$ & $\begin{array}{lr}\text { que facilitou a } \\
\text { aceitação popular } \\
\text { do } & \text { regime } \\
\text { democrático } & \\
\text { imposto. O fato da } \\
\text { figura } & \text { do } \\
\text { Imperador } & \\
\text { continuar } & \text { sendo } \\
\text { respeitada } & \text { foi } \\
\text { essencial } & \text { para } \\
\text { abrandar } & \text { a } \\
\text { resistência } & \text { da } \\
\text { população } & \\
\text { japonesa frente à } \\
\text { invasão }\end{array}$ & $\begin{array}{l}\text { constantes ataques } \\
\text { terroristas contra } \\
\text { estrangeiros no } \\
\text { país. }\end{array}$ & $\begin{array}{l}\text { como por exemplo, } \\
\text { segurança, } \\
\text { fornecimento de } \\
\text { alimentos e de } \\
\text { saneamento básico, } \\
\text { apresentaram } \\
\text { índices inferiores } \\
\text { aos existentes } \\
\text { durante o período } \\
\text { autoritário. }\end{array}$ \\
\hline $\begin{array}{l}\text { Construção de } \\
\text { instituições } \\
\text { governamentais } \\
\text { democráticas }\end{array}$ & $\begin{array}{l}\text { Desde o início da } \\
\text { intervenção, os } \\
\text { norte-americanos } \\
\text { se preocuparam } \\
\text { em substituir as } \\
\text { instituições } \\
\text { autoritárias } \\
\text { nazistas pelas } \\
\text { democráticas. Em } \\
\text { 1946, uma nova } \\
\text { polícia foi } \\
\text { constituída, e a } \\
\text { accountability das } \\
\text { instituições } \\
\text { passou a ser um } \\
\text { fator importante } \\
\text { para a instauração } \\
\text { democrática. }\end{array}$ & $\begin{array}{l}\text { Os norte- } \\
\text { americanos } \\
\text { implantaram } \\
\text { instituições } \\
\text { democráticas } \\
\text { sólidas no Japão } \\
\text { logo após a } \\
\text { intervenção, } \\
\text { utilizando-se do } \\
\text { apoio } \\
\text { burocracia estatal } \\
\text { já existente. }\end{array}$ & $\begin{array}{l}\text { As instituições } \\
\text { democráticas são } \\
\text { muito vulneráveis } \\
\text { e a corrupção é } \\
\text { significativa. }\end{array}$ & $\begin{array}{l}\text { As instituições } \\
\text { democráticas ainda } \\
\text { são muito frágeis, } \\
\text { embora os direitos } \\
\text { políticos renham } \\
\text { sido r mais } \\
\text { desenvolvidos do } \\
\text { que as liberdades } \\
\text { civis no contexto } \\
\text { interno do país. }\end{array}$ \\
\hline $\begin{array}{l}\text { Consolidação } \\
\text { democrática }\end{array}$ & $\begin{array}{l}\text { A transição } \\
\text { democrática } \\
\text { ocorreu em 1949, } \\
\text { com a criação da } \\
\text { República Federal } \\
\text { da Alemanha. } \\
\text { Após } \\
\text { momento, esse } \\
\text { democracia alemã } \\
\text { iniciou a sua } \\
\text { consolidação, e o } \\
\text { país se mantém } \\
\text { democrático até a } \\
\text { atualidade. }\end{array}$ & $\begin{array}{l}\text { A transição } \\
\text { democrática } \\
\text { ocorreu em 1953, } \\
\text { após as primeiras } \\
\text { eleições gerais } \\
\text { ocorridas depois } \\
\text { da retirada dos } \\
\text { norte-americanos } \\
\text { do Japão. Após } \\
\text { esse momento, a } \\
\text { democracia no } \\
\text { país iniciou a sua } \\
\text { consolidação, e } \\
\text { ele se mantém } \\
\text { democrático até a } \\
\text { atualidade. }\end{array}$ & Não ocorreu. & Não ocorreu. \\
\hline
\end{tabular}

Fonte: QUEIROZ, Thaís de O. A exportação da democracia liberal pelo uso da força: uma análise comparada dos casos da Alemanha, Japão, Afeganistão e Iraque. Agosto de 2012. Dissertação de Mestrado. Instituto de Relações Internacionais, Universidade de Brasília. Brasília, 2012. 


\section{ANEXO B - DEMOCRATIZAÇÃO NA ÁFRICA DE ACORDO COM A FREEDOM HOUSE E COM O POLITY IV}

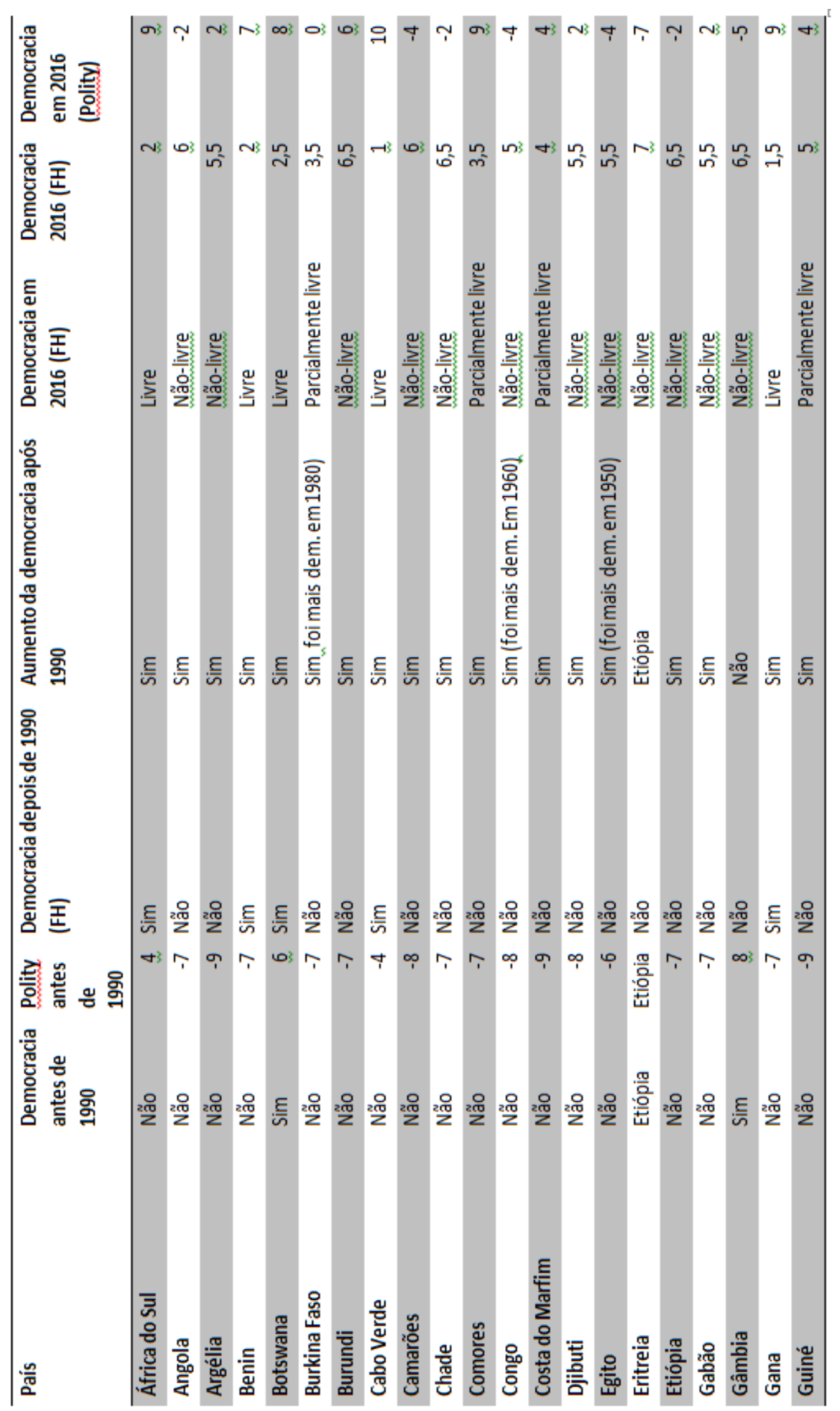




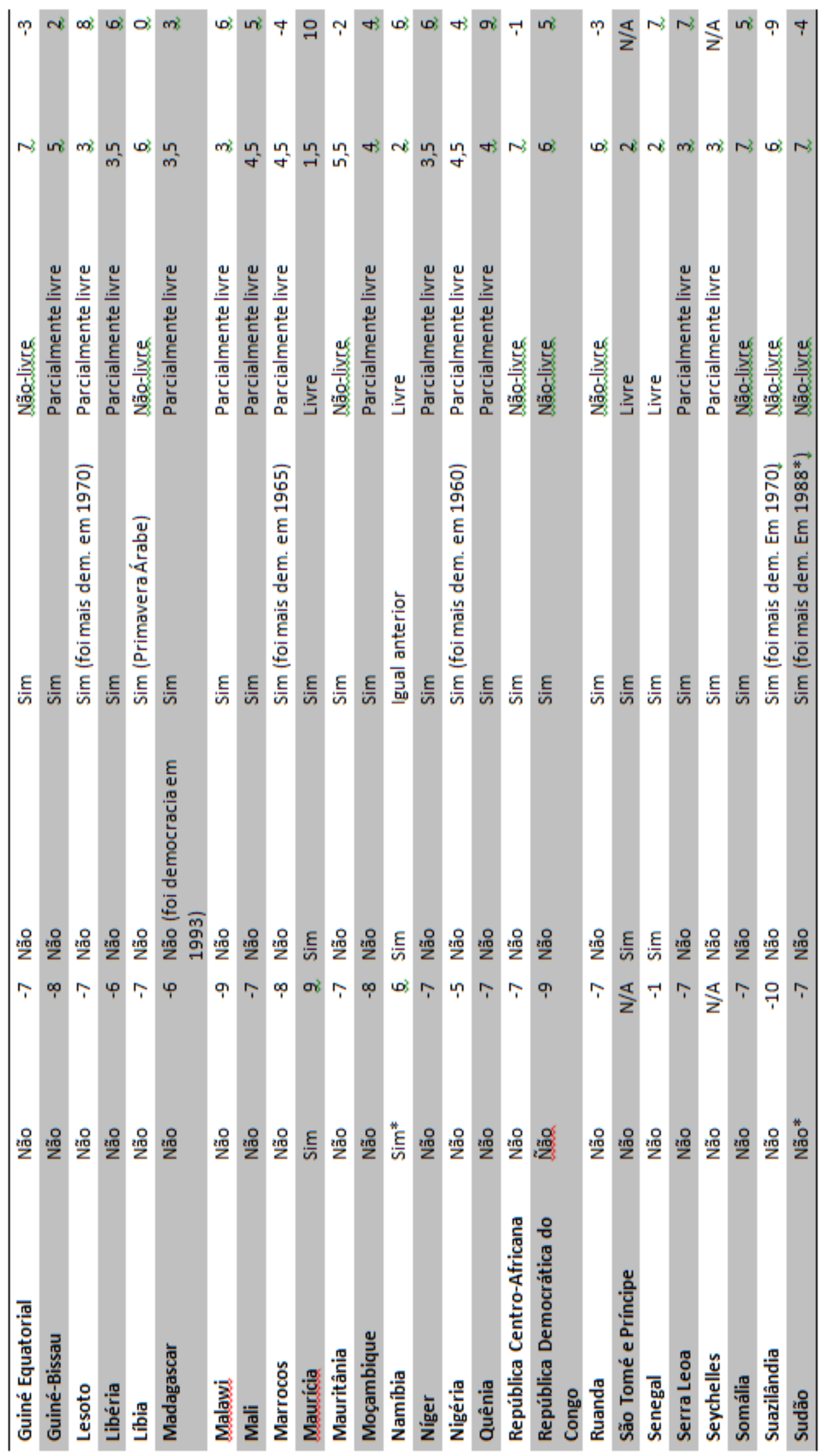




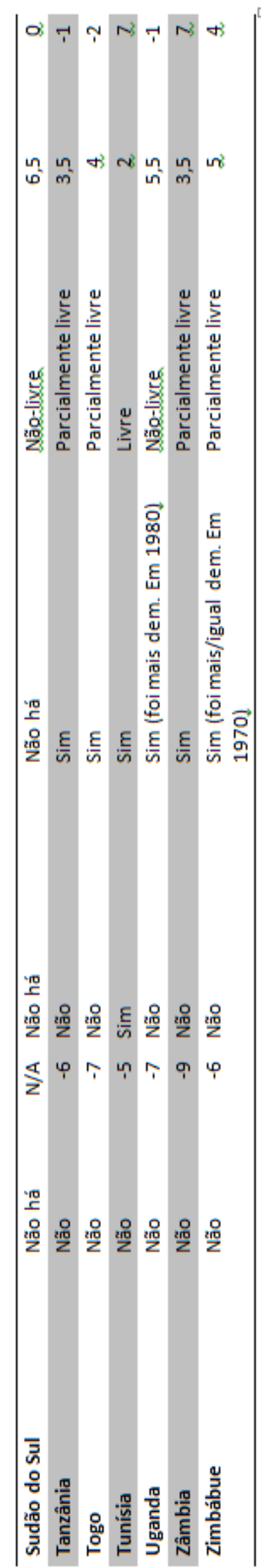

Fonte: Tabela elaborada pela autora. 


\section{ANEXO C - DADOS SOBRE A ÁFRICA: GEOGRAFIA, COLONIZAÇÃO E IDH}

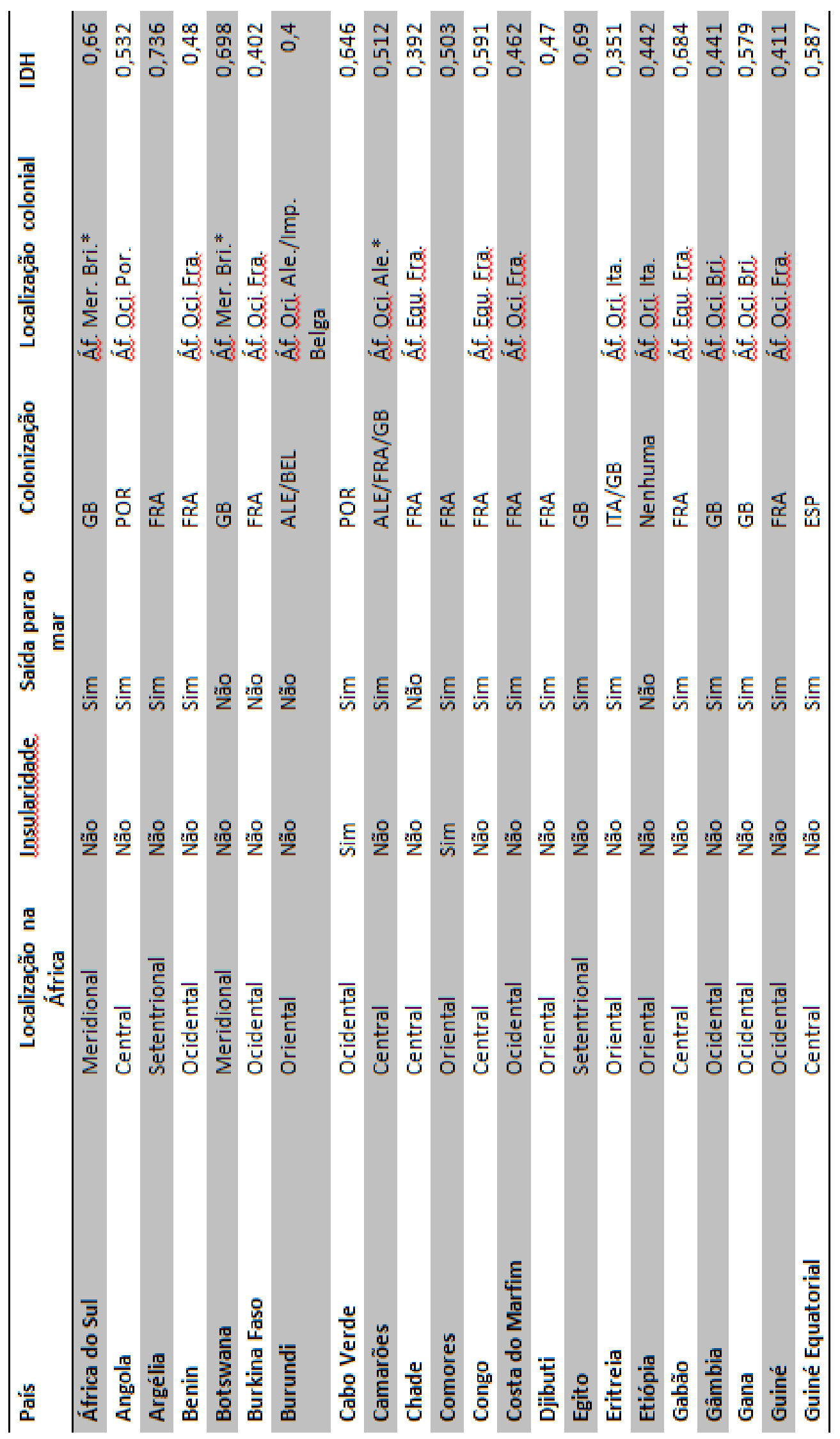




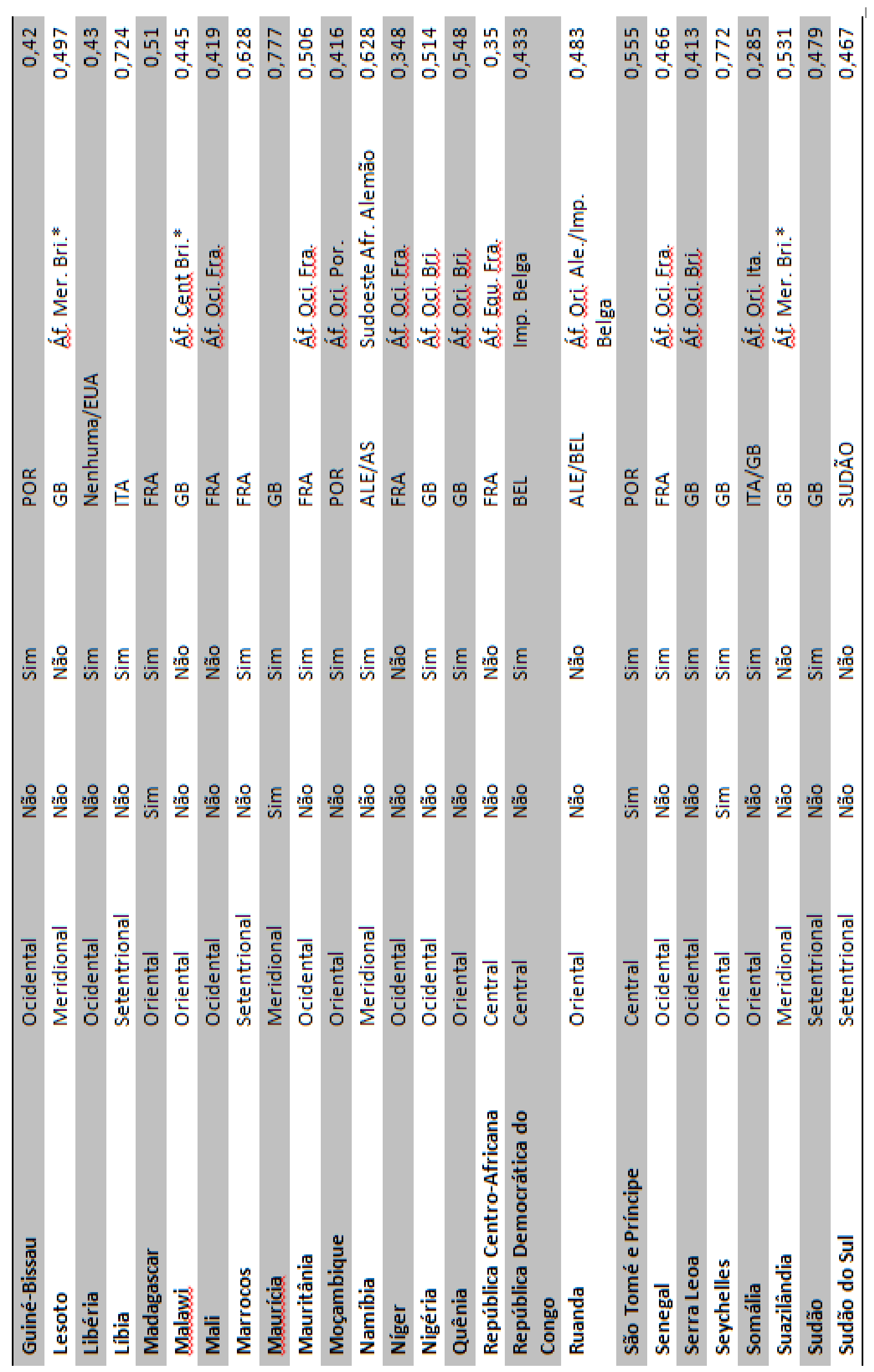




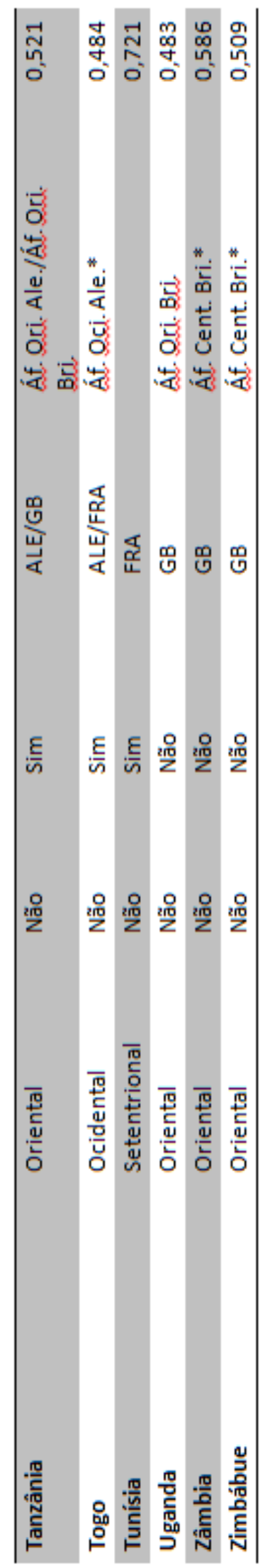

Fonte: Tabela elaborada pela autora. 


\section{ANEXO D - ATO COLONIAL: DECRETO-LEI No 22.465 DE 11 DE ABRIL DE 1933}

\section{Título I - Das garantias gerais}

\section{Artigo 1.}

A Constituição Política da República, em todas as disposições que por sua natureza se não refiram exclusivamente à metrópole, é; aplicável às colónias com os preceitos dos artigos seguintes.

\section{Artigo 2.}

É da essência orgânica da Nação Portuguesa desempenhar a função histórica de possuir e colonizar domínios ultramarinos e de civilizar as populações indígenas que neles se compreendam, exercendo também influência moral que lhe é adstrita pelo Padroado do Oriente.

\section{Artigo 3.}

1.Os domínios ultramarinos de Portugal denominam-se colónias e constituem o Império Colonial Português.

2. O território do Império Colonial Português é definido nos $n .{ }^{\text {os }} 2 .^{\circ}$ a $5 .^{\circ}$ do artigo $1 .^{\circ}$ da Constituição.

\section{Artigo 4.}

São garantidos a nacionais e estrangeiros residentes nas colónias os direitos concernentes à liberdade, segurança individual e propriedade, nos termos da lei.

A uns e outros pode ser recusada a entrada em qualquer colónia, e uns e outros podem ser expulsos, conforme estiver regulado, se da sua presença resultarem graves inconvenientes de ordem interna ou internacional, cabendo unicamente recurso destas resoluções para o Governo.

\section{Artigo 5.}

O Império Colonial Português é solidário nas suas partes componentes e com a metrópole.

\section{Artigo 6.}

A solidariedade do Império Colonial Português abrange especialmente a obrigação de contribuir pela forma adequada para que sejam assegurados os fins de todos os seus membros e a integridade e defesa da Nação.

\section{Artigo 7.}


O Estado não aliena, por nenhum modo, qualquer parte dos territórios e direitos coloniais de Portugal, sem prejuízo da rectificação de fronteiras, quando aprovada pela Assembleia Nacional.

\section{Artigo 8.}

Nas colónias não pode ser adquirido por governo estrangeiro terreno ou edifício para nele ser instalada representação consular senão depois de autorizado pela Assembleia Nacional e em local cuja escolha seja aceite pelo Ministro das Colónias.

\section{Artigo 9.}

Não são permitidas:

1. Numa zona contínua de 80 metros além do máximo nível da praia-mar, as concessões de terrenos confinantes com a costa marítima, dentro ou fora das baías;

2. Numa zona contínua de 80 metros além do nível normal das águas, as concessões de terrenos confinantes com lagos navegáveis e com rios abertos à navegação internacional;

3. Numa faixa não inferior a 100 metros para cada lado, as concessões de terrenos marginais do perímetro das estações das linhas férreas, construídos ou projectadas;

4. Outras concessões de terrenos que não possam ser feitas, conforme as leis que estejam presentemente em vigor ou venham a ser promulgadas.

$\S$ único Em casos excepcionais, quando convenha aos interesses do Estado: Pode ser permitida, conforme a lei, a ocupação temporária de parcelas de terreno situadas nas zonas designadas nos $n .^{\text {os }} 1^{\circ}, 2^{\circ}$ e $3^{\circ}$ deste artigo;

Podem as referidas parcelas ser compreendidas na área das povoações, nos termos legais, com aprovação expressa do Governo, ouvidas as instâncias competentes;

Podem as parcelas assim incluídas na área das povoações ser concedidas, em harmonia com a lei, sendo também condição indispensável a aprovação expressa do Governo, ouvidas as mesmas instâncias.

\section{Artigo 10.}

Nas áreas destinadas a povoações marítimas das colónias, ou à sua natural expansão, as concessões ou subconcessões de terrenos ficam sujeitas às seguintes regras:

1. Não poderão ser feitas a estrangeiros, sem aprovação em Conselho de Ministros;

2. Não poderão ser outorgadas a quaisquer indivíduos ou sociedades senão para aproveitamentos que tenham de fazer para as suas instalações urbanas, industriais ou comerciais.

$\S 1^{\circ}$ Estas proibições são extensivas, nas colónias de África, a todos os actos de transmissão particular que sejam contrários aos fins do presente artigo. $\S 2^{\circ}$ São imprescritíveis os direitos que este artigo e o artigo anterior asseguram ao Estado. 


\section{Artigo 11. ${ }^{\circ}$}

De futuro a administração e exploração dos portos comerciais das colónias são reservadas para o Estado. Lei especial regulará as excepções que dentro de cada porto, em relação a determinadas instalações ou serviços, devam ser admitidas.

\section{Artigo 12.}

O Estado não concede, em nenhuma colónia, a empresas singulares ou colectivas:

1. ${ }^{\circ} \mathrm{O}$ exercício de prerrogativas de administração pública;

2. ${ }^{\circ}$ A faculdade de estabelecer ou fixar quaisquer tributos ou taxas, ainda que sejam em nome do Estado;

3. ${ }^{\circ} \mathrm{O}$ direito de posse de terrenos, ou de áreas de pesquisas minerais, com a faculdade de fazerem subconcessões a outras empresas.

$\S$ único Na colónia onde actualmente houver concessões da natureza daquelas a que refere este artigo observar-se-á o seguinte:

Não poderão ser prorrogadas ou renovadas no todo ou em parte;

O Estado exercerá a seu direito de rescisão ou resgate, nos termos das leis ou contratos aplicáveis;

O Estado terá em vista a completa unificação administrativa da colónia.

\section{Artigo 13.}

As concessões do Estado, ainda quando hajam de ter efeito com aplicação de capitais estrangeiros, serão sempre sujeitas a condições que assegurem a nacionalização e demais conveniências da economia da colónia. Diplomas especiais regularão este assunto para os mesmos fins.

\section{Artigo 14. ${ }^{\circ}$}

Ficam ressalvados, na aplicação dos artigos $8^{\circ}, 9^{\circ}, 10^{\circ}, 11^{\circ}$ e $12^{\circ}$, os direitos adquiridos até a presente data.

\section{Título II - Dos indígenas}

\section{Artigo 15.}

O Estado garante a protecção e defesa dos indígenas das colónias, conforme os princípios de humanidade e soberania, as disposições deste título e as convenções internacionais que actualmente vigoram ou venham a vigorar.

As autoridades coloniais impedirão e castigarão conforme a lei todos os abusos contra a pessoa e bens dos indígenas. 


\section{Artigo 16.}

O Estado estabelece instituições públicas e promove a criação de instituições particulares, portuguesas umas e outras, em favor dos direitos dos indígenas, ou para a sua assistência.

\section{Artigo 17.}

A lei garante aos indígenas, nos termos por ela declarados, a propriedade e posse dos seus terrenos e culturas, devendo ser respeitado este princípio em todas as concessões feitas pelo Estado.

\section{Artigo 18.}

O trabalho dos indígenas em serviço do Estado ou dos corpos administrativos é remunerado.

\section{Artigo 19.}

São proibidos:

1. Todos os regimes pelos quais o Estado se obrigue a fornecer trabalhadores indígenas a quaisquer empresas de exploração económica;

2. Todos os regimes pelos quais os indígenas existentes em qualquer circunscrição territorial sejam obrigados a prestar trabalho às mesmas empresas, por qualquer título.

\section{Artigo 20.}

O Estado somente pode compelir os indígenas ao trabalho em obras públicas de interesse geral da colectividade, em ocupações cujos resultados lhes pertençam, em execução de decisões judiciárias de carácter penal, ou para cumprimento de obrigações fiscais.

\section{Artigo 21.}

O regime do contrato de trabalho dos indígenas assenta na liberdade individual e no direito a justo salário e assistência, intervindo a autoridade pública somente para fiscalização.

\section{Artigo 22.}

Nas colónias atender-se-á ao estado de evolução dos povos nativos, havendo estatutos especiais dos indígenas, que estabeleçam para estes, sob a influência do direito público e privado português, regimes jurídicos de contemporização com os seus usos e costumes individuais, domésticos e sociais, que não sejam incompatíveis com a moral e com os ditames de humanidade. 


\section{Artigo 23.}

O Estado assegura nos seus territórios ultramarinos a liberdade de consciência e o livre exercício dos diversos cultos, com as restrições exigidos pelos direitos e interesses da soberania de Portugal, bem como pela manutenção da ordem pública, e de harmonia com os tratados e convenções internacionais.

\section{Artigo 24. ${ }^{\circ}$}

As missões religiosas do ultramar, instrumento de civilização e de influência nacional, e os estabelecimentos de formação do pessoal para os serviços delas e do Padroado Português, terão personalidade jurídica e serão protegidos e auxiliados pelo Estado, como instituições de ensino.

\section{(...)}

Paços do Governo da República, 11 de Abril de 1933. [ass.] António de Oliveira Salazar, Albino Soares Pinto dos Reis Júnior, Manuel Rodrigues Júnior, Daniel Rodrigues de Sousa, Aníbal de Mesquita Guimarães, César de Sousa Mendes do Amaral e Abranches, Duarte Pacheco, Armindo Rodrigues Monteiro, Gustavo Cordeiro Ramos, Sebastião Garcia Ramires.

Fonte: Diário do Governo, I. ${ }^{\mathrm{a}}$ série, n. ${ }^{\circ} 83$ de 11 de Abril de 1933, págs. 650-652. 


\section{ANEXO E - TRAJETÓRIA ELEITORAL DOS PALOP DE 1975 A 2017}

As trajetórias eleitorais dos PALOP que se encontram expostas a seguir foram construídas utilizando tanto dados do African Elections, que abarcam somente até o ano de 2013, quanto dados de fontes governamentais oficiais entre 2013 e 2017.

Eleições em Cabo Verde (AFRICAN ELECTIONS, 2016)

\section{Período Unipartidário}

Único partido legal: Partido Africano para a Independência da Guiné e Cabo Verde (PAIGC).

\section{Eleições unipartidárias}

\begin{tabular}{|c|l|}
\hline \multicolumn{2}{|l|}{1975} \\
\hline Presidencial ou Legislativa & Legislativa \\
\hline Quantidade de Assentos & 56 \\
\hline Quantidade de Eleitores & 121.724 \\
\hline Total de Votos & - \\
\hline Votos Inválidos & - \\
\hline Votos Válidos & 105.503 \\
\hline Votos “sim” & $100.835(95,58 \%)$ \\
\hline Votos “não” & $4.668(4,42 \%)$ \\
\hline
\end{tabular}

\begin{tabular}{|l|l|}
\hline \multicolumn{2}{|c|}{1980} \\
\hline Presidencial ou Legislativa & Legislativa \\
\hline Quantidade de Assentos & 63 \\
\hline Quantidade de Eleitores & 126.028 \\
\hline Total de Votos & $95.486(75,8 \%)$ \\
\hline Votos Inválidos & 125 \\
\hline Votos Válidos & 95.361 \\
\hline
\end{tabular}




\begin{tabular}{|l|l|}
\hline Votos “sim” & $88.309(92,6 \%)$ \\
\hline Votos “não” & $7.052(7,40 \%)$ \\
\hline
\end{tabular}

\begin{tabular}{|c|l|}
\hline \multicolumn{2}{|l|}{1985} \\
\hline Presidencial ou Legislativa & Legislativa \\
\hline Quantidade de Assentos & 83 \\
\hline Quantidade de Eleitores & 143.303 \\
\hline Total de Votos & $98.692(68,9 \%)$ \\
\hline Votos Inválidos & 402 \\
\hline Votos Válidos & 98.290 \\
\hline Votos “sim” & $93.252(94,87 \%)$ \\
\hline Votos “não” & $5.038(5,13 \%)$ \\
\hline
\end{tabular}

Observação: No período acima, o presidente era eleito pela Assembleia Nacional. No caso, Aristides Pereira foi eleito em 1975, 1981 e 1986.

Eleições multipartidárias

\begin{tabular}{|l|l|}
\hline \multicolumn{2}{|c|}{1991} \\
\hline Presidencial ou Legislativa & Legislativa \\
\hline Quantidade de Assentos & 79 \\
\hline Quantidade de Eleitores & 166.818 \\
\hline Total de Votos & $125.564(75,3 \%)$ \\
\hline \multicolumn{1}{|c|}{ Votos Inválidos } & 7.437 \\
\hline \multicolumn{1}{|c|}{ Votos Válidos } & 118.127 \\
\hline Movimento para a Democracia (MpD) & $78.454(66,41 \%)$ \\
\hline $\begin{array}{l}\text { Partido Africano para Independência } \\
\text { de Cabo Verde (PAICV) }\end{array}$ & $39.673(33,59 \%)$ \\
\hline
\end{tabular}

Observação: a população total em 1990 era de 341.256 habitantes.

\begin{tabular}{|l|l|}
\hline \multicolumn{2}{|c|}{1991} \\
\hline Presidencial ou Legislativa & Presidencial \\
\hline Quantidade de Assentos & 1 \\
\hline Quantidade de Eleitores & 159.667 \\
\hline Total de Votos & $98.039(61,4 \%)$ \\
\hline
\end{tabular}




\begin{tabular}{|c|l|}
\hline Votos Inválidos & 1.735 \\
\hline Votos Válidos & 96.304 \\
\hline António Mascarenhas Monteiro (MpD) & $70.852(73,29 \%)$ \\
\hline Aristides Pereira (PAICV) & $25.722(26,71 \%)$ \\
\hline
\end{tabular}

\begin{tabular}{|l|l|}
\hline \multicolumn{2}{|c|}{1995} \\
\hline Presidencial ou Legislativa & Legislativa \\
\hline Quantidade de Assentos & 72 \\
\hline Quantidade de Eleitores & 207.648 \\
\hline Total de Votos & $158.901(76,5 \%)$ \\
\hline \multicolumn{1}{|c|}{ Votos Inválidos } & 6.779 \\
\hline \multicolumn{1}{|c|}{ Votos Válidos } & 152.122 \\
\hline Movimento para a Democracia (MpD) & $93.249(61,30 \%-50$ assento $)$ \\
\hline $\begin{array}{l}\text { Partido Africano para Independência } \\
\text { de Cabo Verde (PAICV) }\end{array}$ & $45.263(29,75 \%-21$ assentos $)$ \\
\hline $\begin{array}{l}\text { Partido da Convergência Democrática } \\
\text { (PCD) }\end{array}$ & $10.211(6,71 \%$ - 1 assento $)$ \\
\hline $\begin{array}{l}\text { União Caboverdeana Independente e } \\
\text { Democrática (UCID) }\end{array}$ & $2.369(1,56 \%$ - 0 assento $)$ \\
\hline Partido Social Democrático (PSD) & $1.030(0,68 \%$ - 0 assento $)$ \\
\hline
\end{tabular}

\begin{tabular}{|c|c|}
\hline \multicolumn{2}{|c|}{1996} \\
\hline Presidencial ou Legislativa & Presidencial \\
\hline Quantidade de Assentos & 1 \\
\hline Quantidade de Eleitores & - \\
\hline Total de Votos & - (aproximadamente 55\%) \\
\hline Votos Inválidos & - \\
\hline Votos Válidos & - \\
\hline António Mascarenhas Monteiro * & $-(80,1 \%)$ \\
\hline
\end{tabular}

*Nesse ano, o PAICV não lançou candidato, apoiando Monteiro nas eleições. Não houve outro candidato no referido pleito. 


\begin{tabular}{|l|l|}
\hline Presidencial ou Legislativa & Legislativa \\
\hline Quantidade de Assentos & 72 \\
\hline Quantidade de Eleitores & 260.126 \\
\hline Total de Votos & $141.836(54,5 \%)$ \\
\hline \multicolumn{1}{|c|}{ Votos Inválidos } & 4.751 \\
\hline \multicolumn{1}{|c|}{ Votos Válidos } & 137.085 \\
\hline $\begin{array}{l}\text { Partido Africano para Independência } \\
\text { de Cabo Verde (PAICV) }\end{array}$ & $67.860(49,50 \%-40$ assento $)$ \\
\hline Movimento para a Democracia (MpD) & $55.586(40,55 \%$ - 30 assento $)$ \\
\hline $\begin{array}{l}\text { Partido da Aliança para a Mudança } \\
\text { (ADM) }\end{array}$ & $8.389(6,12 \%$ - 2 assento $)$ \\
\hline $\begin{array}{l}\text { Partido da Renovação Democrática } \\
\text { (PRD) }\end{array}$ & $4.630(3,38 \%$ - 0 assento) \\
\hline Partido Social Democrático (PSD) & $620(0,45 \%$ - 0 assento) \\
\hline
\end{tabular}

Observação: A população total do país em 2000 era de 438.737 pessoas.

\begin{tabular}{|c|l|}
\hline \multicolumn{2}{|c|}{ 2001 (Primeiro Turno) } \\
\hline Presidencial ou Legislativa & Presidencial \\
\hline Quantidade de Assentos & 1 \\
\hline Quantidade de Eleitores Registrados & 260.221 \\
\hline Total de Votos & $134.495(51,7 \%)$ \\
\hline Votos Inválidos & 1.999 \\
\hline Votos Válidos & 132.496 \\
\hline Pedro Pires (PAICV) & $61.646(46,52 \%)$ \\
\hline Carlos Veiga (MpD) & $60.719(45,83 \%)$ \\
\hline Jorge Carlos Fonseca & $5.142(3,88 \%)$ \\
\hline David Hopper Almada & $4.989(3,77 \%)$ \\
\hline
\end{tabular}

\begin{tabular}{|l|l|}
\hline \multicolumn{2}{|c|}{2001 (Segundo Turno) } \\
\hline Presidencial ou Legislativa & Presidencial \\
\hline Quantidade de Assentos & 1 \\
\hline Quantidade de Eleitores Registrados & 260.209 \\
\hline Total de Votos & $153.406(59,0 \%)$ \\
\hline
\end{tabular}




\begin{tabular}{|c|l|}
\hline Votos Inválidos & 1.764 \\
\hline Votos Válidos & 151.642 \\
\hline Pedro Pires (PAICV) & $75.827(50 \%)$ \\
\hline Carlos Veiga (MpD) & $75.815(50 \%)$ \\
\hline
\end{tabular}

*Pedro Pires ganhou as eleições com somente 12 votos de diferença para o segundo candidato.

\begin{tabular}{|l|l|}
\hline \multicolumn{2}{|c|}{2006} \\
\hline Presidencial ou Legislativa & Legislativa \\
\hline Quantidade de Assentos & 72 \\
\hline Quantidade de Eleitores & 322.735 \\
\hline Total de Votos & $174.858(54,2 \%)$ \\
\hline \multicolumn{1}{|c|}{ Votos Inválidos } & 4.690 \\
\hline \multicolumn{1}{|c|}{ Votos Válidos } & 170.168 \\
\hline $\begin{array}{l}\text { Partido Africano para Independência } \\
\text { de Cabo Verde (PAICV) }\end{array}$ & $88.965(52,28 \%-41$ assentos) \\
\hline Movimento para a Democracia (MpD) & $74.909(44,02 \%$ - 29 assentos) \\
\hline $\begin{array}{l}\text { União Caboverdiana Independente e } \\
\text { Democrática (UCID) }\end{array}$ & $4.495(2,64 \%-2$ assento $)$ \\
\hline $\begin{array}{l}\text { Partido da Renovação Democrática } \\
\text { (PRD) }\end{array}$ & $1.097(0,64 \%$ - 0 assento $)$ \\
\hline Partido Social Democrático (PSD) & $702(0,41 \%$ - 0 assento) \\
\hline
\end{tabular}

Observação: A população total do país em 2006 era 478.265 pessoas.

\begin{tabular}{|l|l|}
\hline \multicolumn{2}{|c|}{2006} \\
\hline Presidencial ou Legislativa & Presidencial \\
\hline Quantidade de Assentos & 1 \\
\hline Quantidade de Eleitores Registrados & 323.554 \\
\hline Total de Votos & $171.819(53,1 \%)$ \\
\hline Votos Inválidos & 1.995 \\
\hline Votos Válidos & 169.824 \\
\hline Pedro Pires (PAICV) & $86.583(50,98 \%)$ \\
\hline Carlos Veiga (MpD) & $83.241(49,02 \%)$ \\
\hline
\end{tabular}




\begin{tabular}{|l|l|}
\hline \multicolumn{2}{|c|}{2011} \\
\hline Presidencial ou Legislativa & Legislativa \\
\hline Quantidade de Assentos & 72 \\
\hline Quantidade de Eleitores & 298.567 \\
\hline Total de Votos & $226.942(76,0 \%)$ \\
\hline \multicolumn{1}{|c|}{ Votos Inválidos } & 2.990 \\
\hline \multicolumn{1}{|c|}{ Votos Válidos } & 223.952 \\
\hline $\begin{array}{l}\text { Partido Africano para Independência } \\
\text { de Cabo Verde (PAICV) }\end{array}$ & $117.967(52,68 \%-38$ assentos $)$ \\
\hline Movimento para a Democracia (MpD) & $94.674(42,27 \%$ - 32 assentos) \\
\hline $\begin{array}{l}\text { União Caboverdiana Independente e } \\
\text { Democrática (UCID) }\end{array}$ & $9.842(4,39 \%-2$ assento $)$ \\
\hline $\begin{array}{l}\text { Partido da Renovação Democrática } \\
\text { (PRD) }\end{array}$ & $1.040(0,46 \%$ - 0 assento $)$ \\
\hline Partido Social Democrático (PSD) & $429(0,19 \%$ - 0 assento) \\
\hline
\end{tabular}

\begin{tabular}{|c|l|}
\hline \multicolumn{2}{|c|}{ 2011 (Primeiro Turno) } \\
\hline Presidencial ou Legislativa & Presidencial \\
\hline Quantidade de Assentos & 1 \\
\hline Quantidade de Eleitores Registrados & 304.621 \\
\hline Total de Votos & $162.960(53,5 \%)$ \\
\hline Votos Inválidos & - \\
\hline Votos Válidos & 161.105 \\
\hline Jorge Carlos Fonseca (MpD) & $60.887(37,79 \%)$ \\
\hline Manuel Inocêncio Sousa (PAICV) & $52.612(32,66 \%)$ \\
\hline Aristides Lima & $44.648(27,71 \%)$ \\
\hline Joaquim Monteiro & $2.958(1,84 \%)$ \\
\hline
\end{tabular}

\begin{tabular}{|l|l|}
\hline \multicolumn{2}{|c|}{2011 (Segundo Turno) } \\
\hline Presidencial ou Legislativa & Presidencial \\
\hline Quantidade de Assentos & 1 \\
\hline Quantidade de Eleitores Registrados & 304.621 \\
\hline Total de Votos & $182.363(59,9 \%)$ \\
\hline
\end{tabular}




\begin{tabular}{|l|l|}
\hline Votos Inválidos & 2.249 \\
\hline Votos Válidos & 180.114 \\
\hline Jorge Carlos Fonseca (MpD) & $97.735(54,26 \%)$ \\
\hline Manuel Inocêncio Sousa (PAICV) & $82.379(45,74 \%)$ \\
\hline
\end{tabular}

Observação: População total do país em 2006 era de 495.159 habitantes.

\begin{tabular}{|l|l|}
\hline \multicolumn{2}{|c|}{2016} \\
\hline Presidencial ou Legislativa & Legislativa \\
\hline Quantidade de Assentos & 72 \\
\hline Quantidade de Eleitores & 347.622 \\
\hline Total de Votos & $229.337(65,97 \%)$ \\
\hline \multicolumn{1}{|c|}{ Votos Inválidos } & 3.774 \\
\hline \multicolumn{1}{|c|}{ Votos Válidos } & 225.337 \\
\hline Movimento para a Democracia (MpD) & $122.881(53,58 \%$ - 40 assento) \\
\hline $\begin{array}{l}\text { Partido Africano para Independência } \\
\text { de Cabo Verde (PAICV) }\end{array}$ & $86.078(37,53 \%$ - 29 assentos) \\
\hline $\begin{array}{l}\text { União Caboverdiana Independente e } \\
\text { Democrática (UCID) }\end{array}$ & $15.488(6,75 \%$ - 3 assento) \\
\hline Partido Popular (PP) & $777(0,34 \%$ - 0 assento) \\
\hline Partido Social Democrático (PSD) & $232(0,10 \%$ - 0 assento) \\
\hline $\begin{array}{l}\text { Partido do Trabalho e Solidariedade } \\
\text { (PTS) }\end{array}$ & $107(0,05 \%$ - 0 assento) \\
\hline
\end{tabular}

Fonte: CABO VERDE. Comissão Nacional de Eleições. Eleições Legislativas 2016, 2016. Disponível em:

$<$ https://www.cne.cv/index.php?option=com_content\&view=article\&id=348\&Itemid=1 86>. Acesso em: 28 jan. 2016.

\begin{tabular}{|l|l|}
\hline \multicolumn{2}{|c|}{$\mathbf{2 0 1 6}$} \\
\hline Presidencial ou Legislativa & Presidencial \\
\hline Quantidade de Assentos & 1 \\
\hline Quantidade de Eleitores Registrados & 361.221 \\
\hline Total de Votos & $128.117(35,47 \%)$ \\
\hline Votos Inválidos & 2.565 \\
\hline
\end{tabular}




\begin{tabular}{|l|l|}
\hline Votos Válidos & 125.544 \\
\hline Jorge Carlos Fonseca (MpD) & $93.010(74,09 \%)$ \\
\hline $\begin{array}{l}\text { Albertino Emanuel Lopes da Graça } \\
\text { (MpD) }\end{array}$ & $28.256(22,51 \%)$ \\
\hline Jaime Joaquim Monteiro & $4.278(3,41 \%)$ \\
\hline
\end{tabular}

Observação: houve uma taxa de abstenção da ordem de quase $65 \%$.

Fonte: CABO VERDE. Ministério da Justiça e Trabalho, Direção Geral de Apoio ao Processo Eleitoral, Comissão Nacional de Eleições, Boletim Oficial, série I, n. 58, 11 out. 2016. Disponível em: <http://www.dgape.cv/images/bo_11-10-

2016_58presidenciais.pdf>. Acesso em: 28 jan. 2017.

\section{Eleições em São Tomé e Príncipe (AFRICAN ELECTIONS, 2016)}

\section{Eleições}

\section{Eleições unipartidárias}

Único partido legal: Movimento para a Libertação de São Tomé e Príncipe (MLSTP)

1975: Assembleia Nacional Constituinte (16 assentos)*

1980: Assembleia Nacional (40 assentos)*

1985: Assembleia Nacional (40 assentos)*

*Nesses três anos, Manuel Pinto da Costa foi eleito presidente pela Assembleia Nacional.

1990: Referendo Constitucional. 38.100 votos a favor $(95,3 \%)$ e 1.852 contra $(4,6 \%)$.

\section{Eleições multipartidárias}

\begin{tabular}{|l|l|}
\hline \multicolumn{2}{|c|}{1991} \\
\hline Presidencial ou Legislativa & Legislativa \\
\hline Quantidade de Assentos & 55 \\
\hline Quantidade de Eleitores & 51.610 \\
\hline Total de Votos & $39.605(76,7 \%)$ \\
\hline Votos Inválidos & - \\
\hline Votos Válidos & - \\
\hline
\end{tabular}




\begin{tabular}{|c|c|}
\hline $\begin{array}{c}\text { Partido da Convergência } \\
\text { Democrática/Grupo Reflexão (PCD- } \\
\text { GR) }\end{array}$ & 33 assentos (54,4\%) \\
\hline $\begin{array}{c}\text { Movimento pela Liberação de São } \\
\text { Tomé e Príncipe - Partido da Social } \\
\text { Democracia (MLSTP-PSD) }\end{array}$ & 21 assentos $(30,5 \%)$ \\
\hline $\begin{array}{c}\text { Coalisão Democrática de Oposição } \\
\text { (CODO) }\end{array}$ & 1 assento $(5 \%)$ \\
\hline Frente Democrática Cristã (FDC) & 0 assento $(1,5 \%)$ \\
\hline Outros & 0 assento $(8,6 \%)$ \\
\hline
\end{tabular}

\begin{tabular}{|l|l|}
\hline \multicolumn{2}{|l|}{1991} \\
\hline Presidencial ou Legislativa & Presidencial \\
\hline Quantidade de Assentos & 1 \\
\hline Quantidade de Eleitores & 52.618 \\
\hline Total de Votos & $32523(61,8 \%)$ \\
\hline Votos Inválidos & 5.919 \\
\hline Votos Válidos & 26.604 \\
\hline Miguel Trovoada* & $26.604(100 \%)$ \\
\hline
\end{tabular}

*Os outros candidatos retiraram suas candidaturas. O candidato foi apoiado pela PCDGR e CODO.

\begin{tabular}{|l|l|}
\hline \multicolumn{2}{|c|}{1994} \\
\hline Presidencial ou Legislativa & Legislativa \\
\hline Quantidade de Assentos & 55 \\
\hline Quantidade de Eleitores Registrados & 55.862 \\
\hline Total de Votos & $29.100(50,1 \%)$ \\
\hline Votos Inválidos & 3.748 \\
\hline Votos Válidos & 25.352 \\
\hline $\begin{array}{c}\text { Movimento pela Liberação de São } \\
\text { Tomé e Príncipe - Partido da Social } \\
\text { Democracia (MLSTP-PSD) }\end{array}$ & $10.782(42,53 \%-27$ assentos) \\
\hline
\end{tabular}




\begin{tabular}{|c|l|}
\hline Ação Democrática Independente (ADI) & $6.660(26,27 \%-14$ assentos) \\
\hline $\begin{array}{c}\text { Partido da Convergência } \\
\text { Democrática/Grupo Reflexão (PCD- } \\
\text { GR) }\end{array}$ & $6.235(24,59 \%-14$ assento $)$ \\
\hline $\begin{array}{c}\text { Coalisão Democrática de Oposição } \\
\text { (CODO) }\end{array}$ & $1.152(4,54 \%-0$ assento $)$ \\
\hline Aliança Popular (AP) & $342(1,35 \%-0$ assento $)$ \\
\hline Frente Democrática Cristã (FDC) & $181(0,71 \%-0$ assento $)$ \\
\hline
\end{tabular}

\begin{tabular}{|l|l|}
\hline \multicolumn{2}{|c|}{1996 (Primeiro Turno) } \\
\hline Presidencial ou Legislativa & Presidencial \\
\hline Quantidade de Assentos & 1 \\
\hline Quantidade de Eleitores Registrados & 50.256 \\
\hline Total de Votos & $38.841(77,3 \%)$ \\
\hline Votos Inválidos & - \\
\hline Votos Válidos & - \\
\hline Miguel Trovoada (ADI) & $40,9 \%$ \\
\hline Manuel Pinto da Costa (MLSTP-PSD) & $39,1 \%$ \\
\hline Alda Bandeira (PCD-GR) & $14,6 \%$ \\
\hline Carlos da Graça & $5,4 \%$ \\
\hline
\end{tabular}

\begin{tabular}{|l|l|}
\hline \multicolumn{2}{|c|}{1996 (Segundo Turno) } \\
\hline Presidencial ou Legislativa & Presidencial \\
\hline Quantidade de Assentos & 1 \\
\hline Quantidade de Eleitores Registrados & 49.606 \\
\hline Total de Votos & $39.020(78,7 \%)$ \\
\hline Votos Inválidos & 1317 \\
\hline Votos Válidos & 37.703 \\
\hline Miguel Trovoada (ADI) & $52,74 \%$ \\
\hline Manuel Pinto da Costa (MLSTP-PSD) & $47,26 \%$ \\
\hline \multicolumn{2}{|c|}{} \\
\hline
\end{tabular}




\begin{tabular}{|c|c|}
\hline Presidencial ou Legislativa & Legislativa \\
\hline Quantidade de Assentos & 55 \\
\hline Quantidade de Eleitores Registrados & 49.639 \\
\hline Total de Votos & $32.108(64,7 \%)$ \\
\hline Votos Inválidos & 2.923 \\
\hline Votos Válidos & 29.185 \\
\hline $\begin{array}{c}\text { Movimento pela Liberação de São } \\
\text { Tomé e Príncipe - Partido da Social } \\
\text { Democracia (MLSTP-PSD) }\end{array}$ & $14.771(50,61 \%-33$ assentos $)$ \\
\hline Ação Democrática Independente (ADI) & $8.227(28,19 \%-16$ assentos $)$ \\
\hline $\begin{array}{c}\text { Partido da Convergência } \\
\text { Democrática/Grupo Reflexão (PCD- } \\
\text { GR) }\end{array}$ & $4.667(15,99 \%-8$ assento $)$ \\
\hline Frente Democrática Cristã (FDC) & $156(0,53 \%-0$ assento $)$ \\
\hline Outros & $1.364(4,67 \%-0$ assento $)$ \\
\hline
\end{tabular}

\begin{tabular}{|c|l|}
\hline \multicolumn{2}{|l|}{2001} \\
\hline Presidencial ou Legislativa & Presidencial \\
\hline Quantidade de Assentos & 1 \\
\hline Quantidade de Eleitores Registrados & 67.374 \\
\hline Total de Votos & $47.635(70,7 \%)$ \\
\hline Votos Inválidos & 703 \\
\hline Votos Válidos & 49.932 \\
\hline Fradique de Menezes (ADI) & $25.896(55,18 \%)$ \\
\hline Manuel Pinto da Costa (MLSTP-PSD) & $18.762(39,98 \%)$ \\
\hline Carlos Tiny & $1.532(3,26 \%)$ \\
\hline Victor Monteiro & $410(0,87 \%)$ \\
\hline Francisco Fortunato Pires & $332(0,71 \%)$ \\
\hline
\end{tabular}

\begin{tabular}{|l|l|}
\hline \multicolumn{2}{|c|}{2002} \\
\hline Presidencial ou Legislativa & Legislativa \\
\hline Quantidade de Assentos & 55 \\
\hline Quantidade de Eleitores Registrados & 60.961 \\
\hline
\end{tabular}




\begin{tabular}{|c|l|}
\hline Total de Votos & $40.412(64,7 \%)$ \\
\hline Votos Inválidos & - \\
\hline Votos Válidos & - \\
\hline $\begin{array}{c}\text { Movimento pela Liberação de São } \\
\text { Tomé e Príncipe - Partido da Social } \\
\text { Democracia (MLSTP-PSD) }\end{array}$ & $15.618(39,56 \%-24$ assentos) \\
Movimento Democrático Força para a \\
$\begin{array}{c}\text { Mudança/Partido da Convergência } \\
\text { Democrática (MDFM-PCD) }\end{array}$ & $15.524(39,37 \%-23$ assentos) \\
\hline Uê Kédadji (UK) & $6398(16,20 \%-8$ assento) \\
\hline Partido dos Trabalhadores de São & \\
Tomé (PTS) & \\
Associação da Voz da População & \\
(AVP)
\end{tabular}

\begin{tabular}{|c|l|}
\hline \multicolumn{2}{|c|}{ 2006* } \\
\hline Presidencial ou Legislativa & Legislativa \\
\hline Quantidade de Assentos & 55 \\
\hline Quantidade de Eleitores Registrados & 79.849 \\
\hline Total de Votos & $53.378(66,8 \%)$ \\
\hline Votos Inválidos & 1.293 \\
\hline Votos Válidos & 52.085 \\
\hline $\begin{array}{c}\text { Movimento Democrático Força para a } \\
\text { Mudança/Partido da Convergência } \\
\text { Democrática (MDFM-PCD) }\end{array}$ & $19.640(37,07 \%$ - 24 assentos) \\
\hline $\begin{array}{c}\text { Movimento pela Liberação de São } \\
\text { Tomé e Príncipe - Partido da Social } \\
\text { Democracia (MLSTP-PSD) }\end{array}$ & $15.733(30,21 \%$ - 23 assentos) \\
\hline $\begin{array}{c}\text { Ação Democrática Independente (ADI) } \\
\text { Movimento Novos Rumos (NR) }\end{array}$ & $10.678(20,50 \%$ - 8 assento) \\
\hline $\begin{array}{c}\text { União dos Democratas para Cidadania } \\
\text { e Desenvolvimento (UDD) }\end{array}$ & $1.156(2,22 \%$ - 0 assento) \\
\hline Frente Democrática Cristã (FDC) & $796(1,53 \%$ - 0 assento $)$ \\
\hline
\end{tabular}




\begin{tabular}{|c|l|}
\hline Uê Kédadji (UK) & $534(1,03 \%$ \% - 0 assento $)$ \\
\hline Partido Liberal Social (PLS) & $413(0,79 \%-0$ assento $)$ \\
\hline Geração da Esperança (GE) & $336(0,65 \%$ - 0 assento $)$ \\
\hline $\begin{array}{c}\text { Partido dos Trabalhadores de São } \\
\text { Tomé (PTS) }\end{array}$ & $284(0,55 \%$ - 0 assento $)$ \\
\hline
\end{tabular}

*Houve boicotes no dia por parte de alguns distritos. Por isso, alguns realizaram novas eleições em data posterior.

\begin{tabular}{|l|l|}
\hline \multicolumn{2}{|c|}{2006} \\
\hline Presidencial ou Legislativa & Presidencial \\
\hline Quantidade de Assentos & 1 \\
\hline Quantidade de Eleitores Registrados & 91.119 \\
\hline Total de Votos & $59.178(64,9 \%)$ \\
\hline Votos Inválidos & 1.638 \\
\hline Votos Válidos & 57.540 \\
\hline Fradique de Menezes (MDFM-PL)* & $34.859(60,58 \%)$ \\
\hline Patrice Trovoada (ADI)** & $18.762(38,82 \%)$ \\
\hline Nilo Guimarães & $342(0,59 \%)$ \\
\hline
\end{tabular}

*Com apoio do Partido Liberal Social (PLS) e a Frente Democrática Cristã (FDC).

**Com apoio do MLSTP-PSD, UDD, CODO, PTS, PPP, UNDP e PRD.

\begin{tabular}{|l|l|}
\hline \multicolumn{2}{|c|}{2010} \\
\hline Presidencial ou Legislativa & Legislativa \\
\hline Quantidade de Assentos & 55 \\
\hline Quantidade de Eleitores Registrados & 78.798 \\
\hline Total de Votos & $70.113(89,0 \%)$ \\
\hline \multicolumn{1}{|c|}{ Votos Inválidos } & 1.531 \\
\hline Votos Válidos & 68.605 \\
\hline Ação Democrática Independente (ADI) & $29.588(43,13 \%-26$ assentos) \\
\hline Movimento pela Liberação de São \\
Tomé e Príncipe - Partido da Social \\
Democracia (MLSTP-PSD)
\end{tabular}




\begin{tabular}{|c|c|}
\hline $\begin{array}{c}\text { Partido da Convergência } \\
\text { Democrática/Grupo Reflexão (PCD- } \\
\text { GR) }\end{array}$ & $9.450(13,91 \%-7$ assento) \\
\hline $\begin{array}{c}\text { Movimento Democrático Força para a } \\
\text { Mudança/Partido Liberal (MDFM-PL) }\end{array}$ & $4.986(7,27 \%-0$ assento $)$ \\
\hline $\begin{array}{c}\text { União dos Democratas para Cidadania } \\
\text { e Desenvolvimento (UDD) }\end{array}$ & $855(1,25 \%-0$ assento $)$ \\
\hline Frente Democrática Cristã (FDC) & $291(0,42 \%-0$ assento $)$ \\
\hline Movimento Socialista (MS) & $260(0,38 \% \%-0$ assento $)$ \\
\hline União Nacional para a Democracia e & $242(0,35 \%-0$ assento $)$ \\
Progresso (UNDP) & \\
\hline $\begin{array}{c}\text { Confederação Democrática } \\
\text { Nacional/Féssu Bassóla (CDN-FB) }\end{array}$ & $204(0,30 \%-0$ assento $)$ \\
\hline Partido CÓDÓ - Movimento da \\
Ressurgência Nacional (CÓDó-MRN)
\end{tabular}

\begin{tabular}{|c|l|}
\hline \multicolumn{2}{|c|}{ 2011 (Primeiro Turno) } \\
\hline Presidencial ou Legislativa & Presidencial \\
\hline Quantidade de Assentos & 1 \\
\hline Quantidade de Eleitores Registrados & 67.374 \\
\hline Total de Votos & $47.635(70,7 \%)$ \\
\hline Votos Inválidos & 703 \\
\hline Votos Válidos & 49.932 \\
\hline Manuel Pinto da Costa & $21.457(35,62 \%)$ \\
\hline Evaristo Carvalho (ADI) & $13.125(21,79 \%)$ \\
\hline Delfim Neves (PCD-GR)* & $8.652(14,36 \%)$ \\
\hline Maria das Neves & $8.461(14,04 \%)$ \\
\hline Elsa Pinto & $22.682(4,45 \%)$ \\
\hline Aurélio Martins (MLSTP-PSD) & $2.446(4,06 \%)$ \\
\hline Filinto Costa Alegre & $2.401(3,99 \%)$ \\
\hline Hélder Barros & $414(0,69 \%)$ \\
\hline Jorge Coelho & $401(0,67 \%)$ \\
\hline Manuel de Deus Lima & $208(0,35 \%)$ \\
\hline &
\end{tabular}


*Com apoio do MDFM-PL.

\begin{tabular}{|c|l|}
\hline \multicolumn{2}{|c|}{ 2011 (Segundo Turno) } \\
\hline Presidencial ou Legislativa & Presidencial \\
\hline Quantidade de Assentos & 1 \\
\hline Quantidade de Eleitores Registrados & 92.639 \\
\hline Total de Votos & $68.640(74,1 \%)$ \\
\hline Votos Inválidos & 2.912 \\
\hline Votos Válidos & 66.448 \\
\hline Manuel Pinto da Costa & $35.140(52,88 \%)$ \\
\hline Evaristo Carvalho (ADI) & $31.308(47,12 \%)$ \\
\hline
\end{tabular}

\begin{tabular}{|c|c|}
\hline \multicolumn{2}{|c|}{2014} \\
\hline Presidencial ou Legislativa & Legislativa \\
\hline Quantidade de Assentos & 55 \\
\hline Quantidade de Eleitores Registrados & 92.790 \\
\hline Total de Votos & $69.510(74,90 \%)$ \\
\hline Votos Inválidos & 2.435 \\
\hline Votos Válidos & 67.075 \\
\hline Ação Democrática Independente (ADI) & $35.267(38,01 \%-33$ assentos $)$ \\
\hline $\begin{array}{c}\text { Movimento pela Liberação de São } \\
\text { Tomé e Príncipe - Partido da Social } \\
\text { Democracia (MLSTP-PSD) }\end{array}$ & $16.573(17,86 \%$ - 16 assentos $)$ \\
\hline $\begin{array}{l}\text { Partido da Convergência Democrática } \\
\text { (PCD) }\end{array}$ & $7.342(7,91 \%$ - 5 assento $)$ \\
\hline $\begin{array}{l}\text { Movimento Democrático Força para a } \\
\text { Mudança/Partido Liberal (MDFM/PL) }\end{array}$ & $2.217(2,39 \%-0$ assento $)$ \\
\hline $\begin{array}{c}\text { Plataforma Nacional para } \\
\text { Desenvolvimento de São Tomé e } \\
\text { Príncipe (PND) }\end{array}$ & $2.207(2,38 \%-0$ assento $)$ \\
\hline $\begin{array}{c}\text { Partido de Estabilidade e Progresso } \\
\text { Social (PEPS) }\end{array}$ & $1.655(1,78 \%-0$ assento $)$ \\
\hline
\end{tabular}




\begin{tabular}{|c|c|}
\hline $\begin{array}{c}\text { União Democrática para a Cidadania e } \\
\text { Desenvolvimento (UDD) }\end{array}$ & $1.252(1,35 \% \%-0$ assento $)$ \\
\hline $\begin{array}{c}\text { União Nacional para a Democracia e } \\
\text { Progresso (UNDP) }\end{array}$ & $163(0,18 \%-0$ assento $)$ \\
\hline Partido Trabalhista Santomense (PTS) & $138(0,15 \%-0$ assento $)$ \\
\hline $\begin{array}{c}\text { Partido CóDÓ - Movimento } \\
\text { Ressurgimento Nacional (CÓDó- }\end{array}$ & $98(0,11 \%-0$ assento $)$ \\
MRN) & $95(0,10 \%-0$ assento $)$ \\
\hline Frente Democrática Cristã (FDC) & $68(0,07 \%-0$ assento $)$ \\
\hline Movimento Socialista (MS) &
\end{tabular}

Fonte: SÃO TOMÉ E PRÍNCIPE. Comissão Eleitoral Nacional. Resultado das

Eleições legislativas de 12 de Outubro de 2014, 2014. Disponível em:

<http://www.cen.st/index.php/eleicoes/eleicoes-legislativa>. Acesso em: 28 jan. 2017.

\begin{tabular}{|c|l|}
\hline \multicolumn{2}{|c|}{ 2016 (Primeiro Turno) } \\
\hline Presidencial ou Legislativa & Presidencial \\
\hline Quantidade de Assentos & 1 \\
\hline Quantidade de Eleitores Registrados & 111.222 \\
\hline Total de Votos & $71.524(62,22 \%)$ \\
\hline Votos Inválidos & 2.314 \\
\hline Votos Válidos & 69.210 \\
\hline Evaristo Carvalho (ADI) & $34.522(49,88 \%)$ \\
\hline Manuel Pinto da Costa & $17.188(24,83 \%)$ \\
\hline Maria das Neves (MLSTP-PSD) & $16.828(24,31 \%)$ \\
\hline Manuel do Rosário & $478(0,69 \%)$ \\
\hline Helder Barros & $194(0,28 \%)$ \\
\hline
\end{tabular}

Fonte: DEUTSCHE WELLE (DW). Presidenciais de 2016 em São Tomé e Príncipe, jul. 2016. Disponível em: <http://www.dw.com/pt-002/presidenciais-de-2016-ems\%C3\%A3o-tom\%C3\%A9-e-pr\%C3\%ADncipe/a-19381602>. Acesso em: 28 jan. 2017.

\begin{tabular}{|l|l|}
\hline \multicolumn{2}{|c|}{2016 (Segundo Turno) } \\
\hline Presidencial ou Legislativa & Presidencial \\
\hline Quantidade de Assentos & 1 \\
\hline Quantidade de Eleitores Registrados & 111.222 \\
\hline Total de Votos & $51.173(46,00 \%)$ \\
\hline
\end{tabular}




\begin{tabular}{|c|l|}
\hline Votos Inválidos & 9.115 \\
\hline Votos Válidos & 42.058 \\
\hline Evaristo Carvalho (ADI) & $42.058(82,18 \%)$ \\
\hline
\end{tabular}

Fonte: DEUTSCHE WELLE (DW). Abstenção "vence" segunda volta das presidenciais em São Tomé, ago. 2016. Disponível em: <http://www.dw.com/pt002/absten\%C3\%A7\%C3\%A3o-vence-segunda-volta-das-presidenciais-ems\%C3\%A3o-tom\%C3\%A9/a-19455527>. Acesso em: 28 jan. 2017.

Eleições em Angola (AFRICAN ELECTIONS, 2016)

\section{Eleições Unipartidárias}

Único partido legal: Movimento Popular de Libertação de Angola (MPLA)

1980: Assembleia Geral - 229 assentos do MPLA-PT

1986: Assembleia Geral - 289 assentos do MPLA-PT

\begin{tabular}{|c|l|}
\hline \multicolumn{2}{|l|}{1992} \\
\hline Presidencial ou Legislativa & Presidencial \\
\hline Quantidade de Assentos & 1 \\
\hline Quantidade de Eleitores Registrados & 4.828 .468 \\
\hline Total de Votos & $4.401 .339(91,2 \%)$ \\
\hline Votos Inválidos & 460.455 \\
\hline Votos Válidos & 3.940 .884 \\
\hline José Eduardo dos Santos (MPLA) & $1.953 .335(49,57 \%)$ \\
\hline Jonas Savimbi (UNITA) & $1.579 .298(40,07 \%)$ \\
\hline Antonio Alberto Neto (PDA) & $85.249(2,16 \%)$ \\
\hline Holden Roberto (FNLA) & $83.135(2,11 \%)$ \\
\hline Honorato Lando (PDLA) & $75.789(1,92 \%)$ \\
\hline Luís dos Passos (PRD) & $58.121(1,47 \%)$ \\
\hline Bengui Pedro João (PSD) & $38.243(0,97 \%)$ \\
\hline Simão Cacete (FpD) [AD-Coligação] & $26.385(0,67 \%)$ \\
\hline Daniel Chipenda* & $20.646(0,52 \%)$ \\
\hline & $11.475(0,29 \%)$ \\
\hline Anália de Victória Pereira (PLD) & \\
\hline
\end{tabular}




\begin{tabular}{l}
\hline Rui de Victória Pereira (PRA) \\
\begin{tabular}{|l|l|}
\hline *Daniel Chipenda, apesar de ter se candidatado independentemente, foi apoiado pelo \\
Partido Nacional Democrático de Angola.
\end{tabular} \\
\end{tabular}

\begin{tabular}{|c|c|}
\hline \multicolumn{2}{|c|}{1992} \\
\hline Presidencial ou Legislativa & Legislativa \\
\hline Quantidade de Assentos & 220 \\
\hline Quantidade de Eleitores Registrados & 4.828 .468 \\
\hline Total de Votos & $4.410 .575(91,3 \%)$ \\
\hline Votos Inválidos & 458.310 \\
\hline Votos Válidos & 3.952 .265 \\
\hline $\begin{array}{c}\text { Movimento Popular de Libertação da } \\
\text { Angola (MPLA) }\end{array}$ & $2.124 .126(53,74 \%-129$ assentos $)$ \\
\hline $\begin{array}{c}\text { União Nacional para Total } \\
\text { Independência da Angola (UNITA) }\end{array}$ & $1.347 .636(34,10 \%-70$ assento $)$ \\
\hline $\begin{array}{c}\text { Frente Nacional de Libertação da } \\
\text { Angola (FNLA) }\end{array}$ & $94.742(2,40 \%-5$ assento $)$ \\
\hline Partido Liberal Democrático (PLD) & $94.269(2,39 \%-3$ assentos $)$ \\
\hline Partido da Renovação Social (PRS) & $89.875(2,27 \%-6$ assentos $)$ \\
\hline $\begin{array}{c}\text { Partido da Renovação Democrática } \\
\text { (PRD) }\end{array}$ & $35.293(0,89 \%-1$ assentos $)$ \\
\hline $\begin{array}{c}\text { Angola Democrática - Coalisão (AD - } \\
\text { Coligação) }\end{array}$ & $34.166(0,86 \% \%-1$ assentos $)$ \\
\hline Partido Democrático Social (PSD) & $33.088(0,84 \%-1$ assentos $)$ \\
\hline $\begin{array}{c}\text { Partido da Aliança Jovem, Operária e } \\
\text { Camponeses (PAJOCA) }\end{array}$ & $13.924(0,35 \%-1$ assentos $)$ \\
\hline Fórum Democrático Angolano (FDA) & $12.038(0,30 \%-1$ assentos $)$ \\
\hline $\begin{array}{c}\text { Partido Democrático para o Progresso } \\
\text { - Aliança Nacional Angolana (PDP - } \\
\text { ANA) }\end{array}$ & $10.608(0,27 \%-1$ assentos $)$ \\
\hline $\begin{array}{c}\text { Partido Democrático Nacional } \\
\text { Angolano (PNDA) }\end{array}$ & $10.281(0,27 \% \%-1$ assentos $)$ \\
\hline $\begin{array}{c}\text { Convenção Nacional Democrática da } \\
\text { Angola (CNDA) }\end{array}$ & $10.237(0,26 \%-0$ assento $)$ \\
\hline
\end{tabular}




\begin{tabular}{|c|c|}
\hline $\begin{array}{c}\text { Partido Social Democrático Angolano } \\
\text { (PSDA) }\end{array}$ & $10.217(0,26 \%-0$ assento) \\
\hline Partido Angolano Independente (PAI) & $9.007(0,23 \%-0$ assento $)$ \\
\hline $\begin{array}{c}\text { Partido Democrático Liberal da } \\
\text { Angola (PDLA) }\end{array}$ & $8.025(0,20 \%-0$ assento $)$ \\
\hline Partido Democrático Angolano (PDA) & $8.014(0,20 \% \%-0$ assento $)$ \\
\hline Partido da Reforma Angolana (PRA) & $6.719(0,17 \%-0$ assento $)$ \\
\hline
\end{tabular}

\begin{tabular}{|c|c|}
\hline \multicolumn{2}{|c|}{2008} \\
\hline Presidencial ou Legislativa & Legislativa \\
\hline Quantidade de Assentos & 220 \\
\hline Quantidade de Eleitores Registrados & 8.256 .584 \\
\hline Total de Votos & $7.213 .281(87,4 \%)$ \\
\hline Votos Inválidos & 762.874 \\
\hline Votos Válidos & 6.450 .407 \\
\hline $\begin{array}{c}\text { Movimento Popular de Libertação da } \\
\text { Angola (MPLA) }\end{array}$ & 191 assentos $(81,64 \%)$ \\
\hline $\begin{array}{c}\text { União Nacional para Total } \\
\text { Independência da Angola (UNITA) }\end{array}$ & 16 assentos $(10,39 \%)$ \\
\hline Partido da Renovação Social (PRS) & 8 assentos $(3,17 \%)$ \\
\hline União Eleitoral Nova Democracia (ND) & 3 assentos $(1,20 \%)$ \\
\hline $\begin{array}{c}\text { Frente Nacional de Libertação da } \\
\text { Angola (FNLA) }\end{array}$ & 2 assentos $(1,11 \%)$ \\
\hline $\begin{array}{c}\text { Partido Democrático para o Progresso } \\
\text { - Aliança Nacional Angolana (PDP - } \\
\text { ANA) }\end{array}$ & 0 assento $(0,51 \%)$ \\
\hline Partido Liberal Democrático (PLD) & 0 assento $(0,33 \%)$ \\
\hline $\begin{array}{c}\text { Angola Democrática - Coalisão (AD - } \\
\text { Coligação) }\end{array}$ & 0 assento $(0,29 \%)$ \\
\hline $\begin{array}{c}\text { Partido para o Suporte Democrático e } \\
\text { Progresso da Angola (PADEPA) }\end{array}$ & 0 assento $(0,27 \%)$ \\
\hline Frente para a Democracia $(\mathrm{FpD})$ & 0 assento $(0,26 \%)$ \\
\hline
\end{tabular}




\begin{tabular}{|c|l|}
\hline $\begin{array}{c}\text { Partido da Aliança Jovem, Operária e } \\
\text { Camponeses (PAJOCA) }\end{array}$ & 0 assento $(0,24 \%)$ \\
\hline $\begin{array}{c}\text { Partido da Renovação Democrática } \\
\text { (PRD) }\end{array}$ & 0 assento $(0,22 \%)$ \\
\hline Plataforma Política Eleitoral (PPE) & 0 assento $(0,19 \%)$ \\
\hline $\begin{array}{c}\text { Fórum Fraternal Angolano - } \\
\text { Coligação (FOFAC) }\end{array}$ & 0 assento $(0,17 \%)$ \\
\hline
\end{tabular}

\begin{tabular}{|c|c|}
\hline \multicolumn{2}{|c|}{2012} \\
\hline Presidencial ou Legislativa & Legislativa \\
\hline Quantidade de Assentos & 220 \\
\hline Quantidade de Eleitores Registrados & 9.757 .671 \\
\hline Total de Votos & $6.124 .669(62,8 \%)$ \\
\hline Votos Inválidos & 368.665 \\
\hline Votos Válidos & 5.756 .004 \\
\hline $\begin{array}{c}\text { Movimento Popular de Libertação da } \\
\text { Angola (MPLA) }\end{array}$ & $4.135 .503(71,84 \%$ - 191 assentos $)$ \\
\hline $\begin{array}{c}\text { União Nacional para Total } \\
\text { Independência da Angola (UNITA) }\end{array}$ & $1.074 .565(18,66 \%$ - 16 assentos $)$ \\
\hline $\begin{array}{c}\text { Convergência Ampla para Salvação da } \\
\text { Angola - Coalisão Eleitoral (CASA- } \\
\text { CE) }\end{array}$ & $345.589(6,00 \%-8$ assentos $)$ \\
\hline Partido da Renovação Social (PRS) & $98.233(1,70 \%-3$ assentos $)$ \\
\hline $\begin{array}{c}\text { Frente Nacional de Libertação da } \\
\text { Angola (FNLA) }\end{array}$ & $65.163(1,13 \%-2$ assentos $)$ \\
\hline União Eleitoral Nova Democracia (ND) & $13.337(0,23 \%-0$ assento $)$ \\
\hline $\begin{array}{c}\text { Partido Popular para o } \\
\text { Desenvolvimento (PAPOD) }\end{array}$ & $8.710(0,15 \%-0$ assento $)$ \\
\hline $\begin{array}{c}\text { Frente Unida para a Mudança de } \\
\text { Angola (FUMA) }\end{array}$ & $8.260(0,14 \%-0$ assento $)$ \\
\hline Conselho Político de Oposição (CPO) & $6.644(0,11 \%-0$ assento $)$ \\
\hline
\end{tabular}


Eleições em Moçambique (AFRICAN ELECTIONS, 2016)

\section{Eleições unipartidárias}

Único partido legal: Frente de Libertação de Moçambique (FRELIMO)

1977: Eleição para a Assembleia Legislativa

1986: Eleição para Assembleia Legislativa (indireta e baseada em reuniões em massa através do país).

\section{Eleições multipartidárias}

\begin{tabular}{|c|c|}
\hline \multicolumn{2}{|c|}{1994} \\
\hline Presidencial ou Legislativa & Presidencial \\
\hline Quantidade de Assentos & 1 \\
\hline Quantidade de Eleitores Registrados & 6.148 .842 \\
\hline Total de Votos & $5.402 .940(87,9 \%)$ \\
\hline Votos Inválidos & 461.425 \\
\hline Votos Válidos & 4.941 .515 \\
\hline Joaquim Chissano (FRELIMO) & $2.633 .740(53,30 \%)$ \\
\hline Afonso Dhlakama (RENAMO) & $1.666 .965(33,73 \%)$ \\
\hline Wehia Ripua (PADEMO) & $141.905(2,87 \%)$ \\
\hline Carlos Reis (UNAMO) & $120.708(2,44 \%)$ \\
\hline Máximo Dias (MONAMO-PMSD) & $115.442(2,34 \%)$ \\
\hline Campira Momboya (PACODE) & $58.848(1,19 \%)$ \\
\hline Yaqub Sibindy (PIMO) & $51.070(1,03 \%)$ \\
\hline Domingos Arouca (FUMO-PCD) & $37.767(0,76 \%)$ \\
\hline Carlos Jeque & $34.588(0,70 \%)$ \\
\hline Casimiro Nhamitambo (SOL) & $32.036(0,65 \%)$ \\
\hline Mário Machel & $24.238(0,49 \%)$ \\
\hline Padimbe Kamati (PPPM) & $24.208(0,4 \%)$ \\
\hline
\end{tabular}




\begin{tabular}{|c|c|}
\hline \multicolumn{2}{|c|}{1994} \\
\hline Presidencial ou Legislativa & Legislativa \\
\hline Quantidade de Assentos & 250 \\
\hline Quantidade de Eleitores Registrados & 6.148 .842 \\
\hline Total de Votos & $5.404 .199(87,9 \%)$ \\
\hline Votos Inválidos & 630.974 \\
\hline Votos Válidos & 4.773 .225 \\
\hline $\begin{array}{l}\text { Frente de Liberação de Moçambique } \\
\text { (FRELIMO) }\end{array}$ & $2.115 .793(44,33 \%-129$ assentos $)$ \\
\hline $\begin{array}{c}\text { Resistência Nacional Moçambicana } \\
\text { (RENAMO) }\end{array}$ & $1.803 .506(37,78 \%$ - 112 assentos $)$ \\
\hline União Democrática [UD] & $245.793(5,15 \%-9$ assentos $)$ \\
\hline Aliança Patriótica [AP] & $93.031(1,95 \%-0$ assento $)$ \\
\hline $\begin{array}{l}\text { Partido Social-Liberal e Democrático } \\
\text { (SOL) }\end{array}$ & $79.622(1,67 \%-0$ assento $)$ \\
\hline $\begin{array}{l}\text { Frente Unida Moçambicana - Partido } \\
\text { de Convergência Democrática (FUMO- } \\
\text { PCD) }\end{array}$ & $66.527(1,39 \%-0$ assento $)$ \\
\hline Partido da Convenção Nacional (PCN) & $60.635(1,27 \%-0$ assento $)$ \\
\hline $\begin{array}{l}\text { Partido Independente de Moçambique } \\
\text { (PIMO) }\end{array}$ & $58.590(1,23 \%-0$ assento $)$ \\
\hline $\begin{array}{l}\text { Partido do Congresso Democrático } \\
\text { (PACODE) }\end{array}$ & $52.446(1,10 \%-0$ assento $)$ \\
\hline $\begin{array}{c}\text { Partido para o Progresso do Povo de } \\
\text { Moçambique (PPPM) }\end{array}$ & $50.793(1,06 \%$ - 0 assento $)$ \\
\hline $\begin{array}{l}\text { Partido Renovador Democrático } \\
\text { (PRD) }\end{array}$ & $48.030(1,01 \%$ - 0 assento $)$ \\
\hline $\begin{array}{c}\text { Partido Democrático de Moçambique } \\
\text { (PADEMO) }\end{array}$ & $36.689(0,77 \%$ - 0 assento $)$ \\
\hline $\begin{array}{c}\text { União Nacional Moçambicana } \\
\text { (UNAMO) }\end{array}$ & $34.809(0,73 \%-0$ assento $)$ \\
\hline
\end{tabular}




\begin{tabular}{|l|l|}
\hline Partido Trabalhista (PT) & $26.961(0,56 \%-0$ assento $)$ \\
\hline
\end{tabular}

\begin{tabular}{|l|l|}
\hline \multicolumn{2}{|c|}{1999} \\
\hline Presidencial ou Legislativa & Presidencial \\
\hline Quantidade de Assentos & 1 \\
\hline Quantidade de Eleitores Registrados & 7.099 .105 \\
\hline Total de Votos & $4.934 .352(69,5 \%)$ \\
\hline Votos Inválidos & 462.364 \\
\hline Votos Válidos & 4.471 .988 \\
\hline Joaquim Chissano (FRELIMO) & $2.338 .333(52,29 \%)$ \\
\hline Afonso Dhlakama (RENAMO) & $2.133 .655(47,71 \%)$ \\
\hline
\end{tabular}

\begin{tabular}{|c|c|}
\hline \multicolumn{2}{|c|}{1999} \\
\hline Presidencial ou Legislativa & Legislativa \\
\hline Quantidade de Assentos & 250 \\
\hline Quantidade de Eleitores Registrados & 7.099 .105 \\
\hline Total de Votos & $4.833 .761(68,1 \%)$ \\
\hline Votos Inválidos & 701.438 \\
\hline Votos Válidos & 4.132 .323 \\
\hline $\begin{array}{c}\text { Frente de Liberação de Moçambique } \\
\text { (FRELIMO) }\end{array}$ & $2.005 .713(48,54 \%-133$ assentos $)$ \\
\hline $\begin{array}{c}\text { Resistência Nacional Moçambicana- } \\
\text { União Eleitoral [RENAMO-UE] }\end{array}$ & $1.603 .811(38,81 \%-117$ assentos $)$ \\
\hline Partido Trabalhista (PT) & $111.139(2,69 \%-0$ assento $)$ \\
\hline $\begin{array}{c}\text { Partido Liberal e Democrático de } \\
\text { Moçambique (PALMO) }\end{array}$ & $101.970(2,47 \%$ - 0 assento $)$ \\
\hline $\begin{array}{c}\text { Partido Social-Liberal e Democrático } \\
\text { (SOL) }\end{array}$ & $83.440(2,02 \%-0$ assento $)$ \\
\hline $\begin{array}{c}\text { União Moçambicana da Oposição } \\
\text { [UMO] }\end{array}$ & $64.117(1,55 \%-0$ assento $)$ \\
\hline União Democrática [UD] & $61.122(1,48 \%-0$ assento $)$ \\
\hline
\end{tabular}




\begin{tabular}{|c|c|}
\hline $\begin{array}{c}\text { Partido Democrático para a } \\
\text { Libertação de Moçambique } \\
\text { (PADELIMO) }\end{array}$ & $33.247(0,80 \%-0$ assento) \\
(PIMO) & $29.456(0,71 \%-0$ assento) \\
\hline $\begin{array}{c}\text { Partido Independente de Moçambique } \\
\text { Partido Nacional dos Operários e dos } \\
\text { Camponeses (PANAOC) }\end{array}$ & $24.527(0,59 \%-0$ assento) \\
\hline $\begin{array}{c}\text { Partido do Progresso Liberal de } \\
\text { Moçambique (PPLM) }\end{array}$ & $11.628(0,28 \%-0$ assento) \\
\hline $\begin{array}{c}\text { Partido de Ampliação Social de } \\
\text { Moçambique (PASOMO) }\end{array}$ & $2.153(0,05 \%-0$ assento $)$ \\
\hline
\end{tabular}

\begin{tabular}{|l|l|}
\hline \multicolumn{2}{|c|}{$\mathbf{2 0 0 4}$} \\
\hline Presidencial ou Legislativa & Presidencial \\
\hline Quantidade de Assentos & 1 \\
\hline Quantidade de Eleitores Registrados & 9.142 .151 \\
\hline Total de Votos & $3.329 .177(36,4 \%)$ \\
\hline Votos Inválidos & 177.999 \\
\hline Votos Válidos & 3.144 .168 \\
\hline Armando Guebuza (FRELIMO) & $2.004 .226(63,74 \%)$ \\
\hline Afonso Dhlakama (RENAMO) & $998.059(31,74 \%)$ \\
\hline \multicolumn{1}{|c|}{ [RENAMO-UE] } & $85815(2,73 \%)$ \\
\hline Raul Domingos (PDD) & $28.656(0,91 \%)$ \\
\hline Yaqub Sibindy (PIMO) & $27.412(0,87 \%)$ \\
\hline Carlos Reis (UNAMO) [MBG]
\end{tabular}

\begin{tabular}{|l|l|}
\hline \multicolumn{2}{|c|}{$\mathbf{2 0 0 4}$} \\
\hline Presidencial ou Legislativa & Legislativa \\
\hline Quantidade de Assentos & 250 \\
\hline Quantidade de Eleitores Registrados & 914.2151 \\
\hline Total de Votos & $3.321 .926(36,3 \%)$ \\
\hline \multicolumn{1}{|c|}{ Votos Inválidos } & 276.497 \\
\hline
\end{tabular}




\begin{tabular}{|c|c|}
\hline Votos Válidos & 3.045 .429 \\
\hline $\begin{array}{l}\text { Frente de Liberação de Moçambique } \\
\text { (FRELIMO) }\end{array}$ & $1.889 .054(62,03 \%-160$ assento $)$ \\
\hline $\begin{array}{c}\text { Resistência Nacional Moçambicana- } \\
\text { União Eleitoral [RENAMO-UE] }\end{array}$ & $905.289(29,73 \%-90$ assento $)$ \\
\hline $\begin{array}{c}\text { Partido para a Paz, Democracia e } \\
\text { Desenvolvimento (PDD) }\end{array}$ & $60.758(2,00 \%-0$ assento $)$ \\
\hline $\begin{array}{c}\text { Partido para a Liberdade e } \\
\text { Solidariedade (PAZS) }\end{array}$ & $20686(0,88 \%-0$ assento $)$ \\
\hline $\begin{array}{c}\text { Partido de Reconciliação Nacional } \\
\text { (PARENA) }\end{array}$ & $18.220(0,60 \%-0$ assento $)$ \\
\hline $\begin{array}{l}\text { Partido Independente de Moçambique } \\
\text { (PIMO) }\end{array}$ & $17.960(0,59 \%-0$ assento $)$ \\
\hline $\begin{array}{l}\text { Partido de Ampliação Social de } \\
\text { Moçambique (PASOMO) }\end{array}$ & $15.740(0,52 \%-0$ assento $)$ \\
\hline Partido Trabalhista (PT) & $14.242(0,47 \%-0$ assento $)$ \\
\hline Partido Social Liberal (SOL) & $13.915(0,46 \%$ - 0 assento $)$ \\
\hline $\begin{array}{c}\text { Partido Ecologista - Movimento da } \\
\text { Terra (PE-MT) }\end{array}$ & $12.985(0,40 \%-0$ assento $)$ \\
\hline $\begin{array}{c}\text { Frente Unida para Mudança e Boa } \\
\text { Governança }[\mathrm{MBG}]\end{array}$ & $11.059(0,36 \%-0$ assento $)$ \\
\hline União Democrática (UD) & $10.310(0,34 \%-0$ assento $)$ \\
\hline Partido Verde de Moçambique (PVM) & $9.950(0,33 \%-0$ assento $)$ \\
\hline $\begin{array}{c}\text { Partido Liberal e Democrático de } \\
\text { Moçambique (PALMO) }\end{array}$ & $9.263(0,30 \%-0$ assento $)$ \\
\hline $\begin{array}{l}\text { Partido de Reconciliação Democrática } \\
\text { (PAREDE) }\end{array}$ & $9.026(0,30 \%-0$ assento $)$ \\
\hline $\begin{array}{c}\text { União para a Salvação de Moçambique } \\
\text { [USAMO] }\end{array}$ & $8.661(0,29 \%$ - 0 assento $)$ \\
\hline Frente Ampla de Oposição [FAO] & $7.591(0,25 \%-0$ assento $)$ \\
\hline $\begin{array}{c}\text { Partido Democrático para a Libertação } \\
\text { de Moçambique (PADELIMO) }\end{array}$ & $3.720(0,12 \%-0$ assento $)$ \\
\hline
\end{tabular}




\begin{tabular}{|c|c|}
\hline $\begin{array}{c}\text { Congresso dos Democratas Unidos } \\
\text { (CDU) }\end{array}$ & $1.252(0,04 \%-0$ assento $)$ \\
\hline $\begin{array}{c}\text { Partido Popular Democrático de } \\
\text { Moçambique (PPD) }\end{array}$ & $448(0,01 \%-0$ assento $)$ \\
\hline
\end{tabular}

\begin{tabular}{|l|l|}
\hline \multicolumn{2}{|l|}{2009} \\
\hline Presidencial ou Legislativa & Presidencial \\
\hline Quantidade de Assentos & 1 \\
\hline Quantidade de Eleitores Registrados & 9.817 .949 \\
\hline Total de Votos & $4.406 .093(44,6 \%)$ \\
\hline Votos Inválidos & 3.965 .885 \\
\hline Votos Válidos & 3.965 .885 \\
\hline Armando Guebuza (FRELIMO) & $2.974 .627(75,01 \%)$ \\
\hline Afonso Dhlakama (RENAMO) & $650.679(16,41 \%)$ \\
\hline Daviz Simango (MDM) & $340.579(8,59 \%)$ \\
\hline
\end{tabular}

\begin{tabular}{|l|l|}
\hline \multicolumn{2}{|c|}{2009} \\
\hline Presidencial ou Legislativa & Legislativa \\
\hline Quantidade de Assentos & 250 \\
\hline Quantidade de Eleitores Registrados & 9.871 .949 \\
\hline Total de Votos & $4.387 .250(36,3 \%)$ \\
\hline Votos Inválidos & 493.392 \\
\hline $\begin{array}{c}\text { Votos Válidos } \\
\text { (FRELIMO) }\end{array}$ & 3.893 .858 \\
\hline $\begin{array}{c}\text { Frente de Liberação de Moçambique } \\
\text { (RENAMO) }\end{array}$ & $2.907 .335(74,66 \%-191$ assentos $)$ \\
\hline $\begin{array}{c}\text { Resistência Nacional Moçambicana } \\
\text { Moçambique (MDM) }\end{array}$ & $688.782(17,69 \%-51$ assentos $)$ \\
\hline $\begin{array}{c}\text { Partido da Liberdade e } \\
\text { Desenvolvimento (PLD) }\end{array}$ & $152.836(3,93 \%-8$ assentos) \\
\hline
\end{tabular}




\begin{tabular}{|c|c|}
\hline $\begin{array}{c}\text { Partido para a Paz, Democracia e } \\
\text { Desenvolvimento (PDD) }\end{array}$ & $22.410(0,58 \%$ - 0 assento $)$ \\
\hline Partido Verde de Moçambique (PVM) & $19.577(0,50 \%$ - 0 assento $)$ \\
\hline $\begin{array}{l}\text { Aliança Democrática de Veteranos } \\
\text { para o Desenvolvimento [ADACD] }\end{array}$ & $17.275(0,44 \%$ - 0 assento $)$ \\
\hline $\begin{array}{c}\text { Partido para a Liberdade e } \\
\text { Solidariedade (PAZS) }\end{array}$ & $16.626(0,43 \%-0$ assento $)$ \\
\hline $\begin{array}{l}\text { Aliança Independente de Moçambique } \\
\text { (ALIMO) }\end{array}$ & $14.959(0,38 \%$ - 0 assento $)$ \\
\hline União Eleitoral - Coalisão [UE] & $6.786(0,17 \%-0$ assento $)$ \\
\hline $\begin{array}{c}\text { Partido de Reconciliação Nacional } \\
\text { (PARENA) }\end{array}$ & $5.610(0,14 \%-0$ assento $)$ \\
\hline $\begin{array}{c}\text { Partido Ecologista - Movimento da } \\
\text { Terra (PEC-MT) }\end{array}$ & $5.267(0,14 \%-0$ assento $)$ \\
\hline $\begin{array}{c}\text { Movimento Patriótico para a } \\
\text { Democracia (MPD) }\end{array}$ & $2.433(0,06 \%-0$ assento $)$ \\
\hline $\begin{array}{c}\text { União dos Democratas de Moçambique } \\
\text { (UDM) }\end{array}$ & $2.190(0,06 \%-0$ assento $)$ \\
\hline União para a Mudança (UM) & $1.641(0,04 \%-0$ assento $)$ \\
\hline Partido Trabalhista (PT) & $1.239(0,03 \%-0$ assento $)$ \\
\hline $\begin{array}{c}\text { Partido Nacional dos Operários e dos } \\
\text { Camponeses (PANAOC) }\end{array}$ & $852(0,02 \%-0$ assento $)$ \\
\hline $\begin{array}{c}\text { Partido Popular Democrático de } \\
\text { Moçambique (PPD) }\end{array}$ & $712(0,02 \%-0$ assento $)$ \\
\hline $\begin{array}{c}\text { Partido de Reconciliação Democrática } \\
\text { Social (PRDS) }\end{array}$ & $399(0,01 \%-0$ assento $)$ \\
\hline
\end{tabular}

\begin{tabular}{|l|l|}
\hline \multicolumn{2}{|c|}{$\mathbf{2 0 1 4}$} \\
\hline Presidencial ou Legislativa & Presidencial \\
\hline Quantidade de Assentos & 1 \\
\hline Quantidade de Eleitores Registrados & 10.964 .978 \\
\hline Total de Votos & $5.333 .665(48,64 \%)$ \\
\hline \multicolumn{1}{|c|}{ Votos Inválidos } & 461.861 \\
\hline
\end{tabular}




\begin{tabular}{|c|l|}
\hline Votos Válidos & 4.871 .804 \\
\hline Filipe Jacinto Nyusi (FRELIMO) & $2.778 .497(57,03 \%)$ \\
\hline Afonso Dhlakama (RENAMO) & $1.738 .382(36,61 \%)$ \\
\hline Daviz Simango (MDM) & $309.925(6,36 \%)$ \\
\hline
\end{tabular}

Fonte: MOÇAMBIQUE. Comissão Nacional de Eleições. Edital: Apuramento Geral / Presidente da República. Disponível em: <http://www.stae.org.mz/index.php/en/201508-21-21-06-05/2015-08-22-13-47-08/2015-08-22-13-48-17?download=50:resutadodas-eleicoes-presidenciais-2014>. Acesso em: 29 jan. 2017.

\begin{tabular}{|l|l|}
\hline \multicolumn{2}{|c|}{2014} \\
\hline Presidencial ou Legislativa & Legislativa \\
\hline Quantidade de Assentos & 250 \\
\hline Quantidade de Eleitores Registrados & 10.964 .978 \\
\hline Total de Votos & $5.316 .936(41 \%)$ \\
\hline Votos Inválidos & 252.535 \\
\hline $\begin{array}{c}\text { Votos Válidos } \\
\text { (FRELIMO) }\end{array}$ & 4.508 .142 \\
\hline $\begin{array}{c}\text { Frente de Liberação de Moçambique } \\
\text { (RENAMO) }\end{array}$ & $2.575 .955(55,93 \%-144$ assentos $)$ \\
\hline $\begin{array}{c}\text { Resistência Nacional Moçambicana } \\
\text { Moçambique (MDM) }\end{array}$ & $1.495 .137(32,46 \%-89$ assentos $)$ \\
\hline Outros & $384.538(8,35 \%-17$ assentos) \\
\hline
\end{tabular}

Fonte: ELECTION GUIDE. Republico f Mozambique: Election for Assembleia da República (Assembly of the Republic), out. 2014. Disponível em:

<http://www.electionguide.org/elections/id/2410/>. Acesso em: 30 jan. 2016.

\section{Eleições em Guiné-Bissau (AFRICAN ELECTIONS, 2016)}

\section{Eleições unipartidárias}

Único partido legal: Partido Africano para a Independência da Guiné e Cabo Verde (PAIGC)

1972: Eleições Regionais de Conselho. 97,13\% votaram sim e votaram "não" no partido. 
1977: Eleições Regionais de Conselho - 150 assentos

1984: Eleições Regionais de Conselho - 150 assentos

1989: Eleições Regionais de Conselho - 150 assentos. 53\% de comparecimento do total de eleitores registrados.

\section{Eleições multipartidárias}

\begin{tabular}{|c|l|}
\hline \multicolumn{2}{|c|}{1994 (Primeiro Turno) } \\
\hline Presidencial ou Legislativa & Presidencial \\
\hline Quantidade de Assentos & 1 \\
\hline Quantidade de Eleitores Registrados & 400.417 \\
\hline Total de Votos & $357.682(89,3 \%)$ \\
\hline Votos Inválidos & 49.059 \\
\hline Votos Válidos & 308.623 \\
\hline João Bernado “Nino" Vieira (PAIGC) & $142.577(46,20 \%)$ \\
\hline Kumba Ialá (PRS) & $67.518(21,88 \%)$ \\
\hline Domingos Fernandes (RGB-MB) & $53.825(17,44 \%)$ \\
\hline Carlos Gomes* & $15.645(5,07 \%)$ \\
\hline François Mendy (FLING) & $8.655(2,80 \%)$ \\
\hline Bubacar Rachid Djaló (LIPE) [UM] & $8.506(2,76 \%)$ \\
\hline Victor Saúde Maria (PUSD) & $6.388(2,07 \%)$ \\
\hline Antonieta Rosa Gomes (FCG-SD) & $5.509(1,79 \%)$ \\
\hline
\end{tabular}

\section{4 (Segundo Turno)}

\begin{tabular}{|l|l|}
\hline Presidencial ou Legislativa & Presidencial \\
\hline Quantidade de Assentos & 1 \\
\hline Quantidade de Eleitores Registrados & 400.417 \\
\hline Total de Votos & $326.615(81,6 \%)$ \\
\hline \multicolumn{1}{|c|}{ Votos Inválidos } & 16.868 \\
\hline Votos Válidos & 30.747 \\
\hline João Bernardo “Nino" Vieira (PAIGC) & $161.083(52,00 \%)$ \\
\hline Kumba Ialá (PRS) & $148.664(48,00 \%)$ \\
\hline
\end{tabular}




\begin{tabular}{|l|l|}
\hline \multicolumn{2}{|c|}{1994} \\
\hline Presidencial ou Legislativa & Legislativas \\
\hline Quantidade de Assentos & 100 \\
\hline Quantidade de Eleitores Registrados & 400.417 \\
\hline Total de Votos & $355.992(88,9 \%)$ \\
\hline Votos Inválidos e Brancos & 65.024 \\
\hline $\begin{array}{c}\text { Votos Válidos } \\
\text { Partido Africano para a Independência } \\
\text { da Guiné e Cabo Verde (PAIGC) }\end{array}$ & $134.982(46 \%-62$ assentos) \\
\hline $\begin{array}{c}\text { Resistência da Guiné-Bissau / } \\
\text { Movimento Bafatá (RGB-MB) }\end{array}$ & $257.566(19,78 \%-19$ assentos) \\
\hline $\begin{array}{c}\text { União para Mudança (UM) } \\
\text { Partido da Renovação Social (PRS) }\end{array}$ & $36.797(12,65 \%$ - 6 assentos) \\
\hline $\begin{array}{c}\text { Partido da Convergência Democrática } \\
\text { (PCD) }\end{array}$ & $15.411(5,30 \%$ - 1 assentos) \\
\hline $\begin{array}{c}\text { Partido da União Social Democrática } \\
\text { (PUSD) }\end{array}$ & $8.286(2,85 \%$ - 0 assento) \\
\hline $\begin{array}{c}\text { Frente pela Libertação e } \\
\text { Independência da Guiné (FLING) }\end{array}$ & $7.475(2,57 \%$ - 1 assento) \\
\hline $\begin{array}{c}\text { Fórum Cívico Guineense - Social } \\
\text { Democracia (FCG-SD) }\end{array}$ & $494(0,17 \%$ - 0 assento) \\
\hline
\end{tabular}

\begin{tabular}{|c|l|}
\hline \multicolumn{2}{|c|}{1999} \\
\hline Presidencial ou Legislativa & Legislativas \\
\hline Quantidade de Assentos & 102 \\
\hline Quantidade de Eleitores Registrados & - \\
\hline Total de Votos & - \\
\hline Votos Inválidos e Brancos & - \\
\hline Votos Válidos & - \\
\hline $\begin{array}{c}\text { Partido da Renovação Social (PRS) } \\
\text { Resistência da Guiné-Bissau / } \\
\text { Movimento Bafatá (RGB-MB) }\end{array}$ & 38 assentos \\
\hline $\begin{array}{c}\text { Partido Africano para a Independência } \\
\text { da Guiné e Cabo Verde (PAIGC) }\end{array}$ & 24 assentos \\
\hline Aliança Democrática (AD) & 3 assentos \\
\hline União para a Mudança (UM) & 3 assentos \\
\hline $\begin{array}{c}\text { Partido Social Democrático (PSD) } \\
\text { Frente Social Democrática (FDS) }\end{array}$ & 3 assentos \\
\hline
\end{tabular}




\begin{tabular}{|c|l|}
\hline $\begin{array}{c}\text { União Nacional para Democracia e } \\
\text { Progresso (UNDP) }\end{array}$ & 1 assento \\
\hline
\end{tabular}

\begin{tabular}{|c|l|}
\hline \multicolumn{2}{|c|}{1999 (Primeiro Turno) } \\
\hline Presidencial ou Legislativa & Presidencial \\
\hline Quantidade de Assentos & 1 \\
\hline Quantidade de Eleitores Registrados & 503.007 \\
\hline Total de Votos & - \\
\hline Votos Inválidos & - \\
\hline Votos Válidos & 371.025 \\
\hline Kumba Ialá (PRS) & $143.996(38,81 \%)$ \\
\hline Malam Bacai Sanhá (PAIGC) & $86.724(23,37 \%)$ \\
\hline Faustino Fudut Imbali & $30.484(8,22 \%)$ \\
\hline Fernando Gomes & $26.049(7,02 \%)$ \\
\hline João Tátis Sá & $24.117(6,50 \%)$ \\
\hline Abubacar Baldé (UNDP) & $20.192(5,44 \%)$ \\
\hline Bubacar Rachid Djaló (LIPE) & $12.026(3,24 \%)$ \\
\hline Joaquim Baldé (PSD) & $8.623(2,32 \%)$ \\
\hline Salvador Tchongó (RGB-MB) & $6.937(1,87 \%)$ \\
\hline Mamadengul Mendes (FLING) & $5.311(1,43 \%)$ \\
\hline Antonieta Rosa Gomes (FCG-SD) & $3.580(0,96 \%)$ \\
\hline Baldé (PRP) & $2.986(0,80 \%)$ \\
\hline
\end{tabular}

\begin{tabular}{|l|l|}
\hline \multicolumn{2}{|c|}{ 2000 (Segundo Turno) } \\
\hline Presidencial ou Legislativa & Presidencial \\
\hline Quantidade de Assentos & 1 \\
\hline Quantidade de Eleitores Registrados & 503007 \\
\hline Total de Votos & $361609(71,9 \%)$ \\
\hline Votos Inválidos & 12746 \\
\hline Votos Válidos & 348863 \\
\hline Kumba Ialá (PRS) & $252.193(72,00 \%)$ \\
\hline Malam Bacai Sanhá (PAIGC) & $97.670(28,00 \%)$ \\
\hline
\end{tabular}




\begin{tabular}{|c|c|}
\hline \multicolumn{2}{|c|}{2004} \\
\hline Presidencial ou Legislativa & Legislativas \\
\hline Quantidade de Assentos & 100 \\
\hline Quantidade de Eleitores Registrados & 603.639 \\
\hline Total de Votos & $460.254(76,2 \%)$ \\
\hline Votos Inválidos e Brancos & 31.317 \\
\hline Votos Válidos & 428.937 \\
\hline $\begin{array}{l}\text { Partido Africano para a Independência } \\
\text { da Guiné e Cabo Verde (PAIGC) }\end{array}$ & $145.316(33,88 \%-45$ assentos $)$ \\
\hline Partido da Renovação Social (PRS) & $113.656(26,50 \%-35$ assentos $)$ \\
\hline $\begin{array}{c}\text { Partido Unido Social Democrático } \\
\text { (PUSD) }\end{array}$ & $75.485(17,60-17$ assento $)$ \\
\hline Plataforma Unida [PLATAFORMA] & $20.700(4,83 \%-0$ assento $)$ \\
\hline União Eleitoral [UE] & $18.354(4,28 \%-2$ assento $)$ \\
\hline Partido Socialista Democrático (PDS) & $8.789(2,05 \%-0$ assento $)$ \\
\hline União para a Mudança (UM) & $8.621(2,01 \%-0$ assento $)$ \\
\hline $\begin{array}{l}\text { Resistência da Guiné-Bissau / } \\
\text { Movimento Bafatá (RGB-MB) }\end{array}$ & $7.918(1,85 \%$ - 0 assento $)$ \\
\hline Partido da Unidade Nacional (PUN) & $6.260(1,46 \%-0$ assento $)$ \\
\hline Aliança Popular Unida [APU] & $5.042(1,36 \%-0$ assento $)$ \\
\hline $\begin{array}{c}\text { União Nacional para Democracia e } \\
\text { Progresso (UNDP) }\end{array}$ & $4.209(1,18 \%$ - 0 assento $)$ \\
\hline $\begin{array}{l}\text { Fórum Cívico Guineense - Democracia } \\
\text { Social (FCG-SD) }\end{array}$ & $4.202(0,98 \%$ - 0 assento $)$ \\
\hline $\begin{array}{c}\text { Movimento Democrático Guineense } \\
\text { (MDG) }\end{array}$ & $4.402(0,98 \%-0$ assento $)$ \\
\hline Partido do Manifesto Popular (PMP) & $3.402(0,79 \%-0$ assento $)$ \\
\hline $\begin{array}{c}\text { Partido Socialista da Guiné-Bissau } \\
\text { (PS-GB) }\end{array}$ & $1.166(0,27 \%-0$ assento $)$ \\
\hline
\end{tabular}

\begin{tabular}{|l|l|}
\hline \multicolumn{2}{|c|}{2005 (Primeiro Turno) } \\
\hline Presidencial ou Legislativa & Presidencial \\
\hline Quantidade de Assentos & 1 \\
\hline Quantidade de Eleitores Registrados & 503.007 \\
\hline Total de Votos & - \\
\hline \multicolumn{1}{|c|}{ Votos Inválidos } & - \\
\hline
\end{tabular}




\begin{tabular}{|c|l|}
\hline Votos Válidos & 371.025 \\
\hline João Bernardo "Nino" Vieira & $128.918(28,87 \%)$ \\
\hline Malam Bacai Sanhá (PAIGC) & $158.276(35,45 \%)$ \\
\hline Kumba Ialá (PRS) & $111.606(25 \%)$ \\
\hline Francisco Fadul (PUSD) & $12.733(2,85 \%)$ \\
\hline Aregado Mantenque Té (PT) & $9.000(2,02 \%)$ \\
\hline Mamadú Iaia Djaló & $7.112(1,59 \%)$ \\
\hline Mário Lopes da Rosa & $4.863(1,09 \%)$ \\
\hline Idrissa Djaló (PUN) & $3.604(0,81 \%)$ \\
\hline Adelino Mano Queta & $2.816(0,63 \%)$ \\
\hline Faustino Fudut Imbali (PMP) & $2.330(1,52 \%)$ \\
\hline Paulino Empossa Ié & $2.215(0,50 \%)$ \\
\hline Antonieta Rosa Gomes (FCG-SD) & $1.642(0,37 \%)$ \\
\hline João Tátis Sá (PPG) & $1.378(0,31 \%)$ \\
\hline
\end{tabular}

\begin{tabular}{|l|l|}
\hline \multicolumn{2}{|c|}{2005 (Segundo Turno) } \\
\hline Presidencial ou Legislativa & Presidencial \\
\hline Quantidade de Assentos & 1 \\
\hline Quantidade de Eleitores Registrados & 503.007 \\
\hline Total de Votos & $361.609(71,9 \%)$ \\
\hline Votos Inválidos & 12.746 \\
\hline Votos Válidos & 348.863 \\
\hline João Bernardo “Nino” Vieira & $216.167(52,35 \%)$ \\
\hline Malam Bacai Sanhá (PAIGC) & $196.759(47,65 \%)$ \\
\hline
\end{tabular}

\begin{tabular}{|l|l|}
\hline \multicolumn{2}{|c|}{2008} \\
\hline Presidencial ou Legislativa & Legislativas \\
\hline Quantidade de Assentos & 100 \\
\hline Quantidade de Eleitores Registrados & 593.739 \\
\hline Total de Votos & $486.873(82,0 \%)$ \\
\hline
\end{tabular}




\begin{tabular}{|c|c|}
\hline Votos Inválidos e Brancos & 27.735 \\
\hline Votos Válidos & 459.138 \\
\hline $\begin{array}{l}\text { Partido Africano para a Independência } \\
\text { da Guiné e Cabo Verde (PAIGC) }\end{array}$ & $227.350(49,52 \%-67$ assentos $)$ \\
\hline Partido da Renovação Social (PRS) & $115.755(25,21 \%-28$ assentos $)$ \\
\hline $\begin{array}{l}\text { Partido Republicano da Independência } \\
\text { para o Desenvolvimento (PRID) }\end{array}$ & $34.341(7,48 \%-3$ assentos $)$ \\
\hline Partido dos Trabalhadores (PT) & $12.600(2,74 \%-0$ assento $)$ \\
\hline $\begin{array}{c}\text { Partido do Trabalhador Nova } \\
\text { Democracia (PND) }\end{array}$ & $10.726(2,34 \%-1$ assento $)$ \\
\hline $\begin{array}{c}\text { Partido Unido Social Democrático } \\
\text { (PUSD) }\end{array}$ & $7.700(1,68 \%-0$ assento $)$ \\
\hline $\begin{array}{c}\text { Partido para a Democracia, } \\
\text { Desenvolvimento e Cidadania } \\
\text { (PADEC) }\end{array}$ & $7.076(1,54 \%-0$ assento $)$ \\
\hline Aliança Democrática [AD] & $6.321(1,38 \%-1$ assento $)$ \\
\hline Partido Social Democrático (PSD) & $6.319(1,38 \%-0$ assento $)$ \\
\hline Aliança de Forças Patrióticas (AFP) & $5.869(1,28 \%-0$ assento $)$ \\
\hline Centro Democrático (CD) & $5.438(1,18 \%$ - 0 assento $)$ \\
\hline Partido da Democracia Popular (PDP) & $5.353(1,17 \%-0$ assento $)$ \\
\hline Partido Progressista (PP) & $3.095(0,67 \%-0$ assento $)$ \\
\hline Partido Democrático Guineense (PDG) & $3.068(0,67 \%-0$ assento $)$ \\
\hline União Patriótica Guineense (UPG) & $2.809(0,61 \%-0$ assento $)$ \\
\hline Partido Socialista Democrático (PDS) & $1.697(0,37 \%$ - 0 assento $)$ \\
\hline $\begin{array}{c}\text { União Nacional para a Democracia e } \\
\text { Progresso (UNDP) }\end{array}$ & $1.328(0,29 \%$ - 0 assento $)$ \\
\hline $\begin{array}{c}\text { Partido da Reconciliação Nacional } \\
\text { (PRN) }\end{array}$ & $783(0,17 \%-0$ assento $)$ \\
\hline $\begin{array}{l}\text { Partido Socialista da Guiné-Bissau } \\
\text { (PS-GB) }\end{array}$ & $639(0,14 \%-0$ assento $)$ \\
\hline $\begin{array}{c}\text { Movimento Democrático Guineense } \\
\text { (MDG) }\end{array}$ & $638(0,14 \%-0$ assento $)$ \\
\hline $\begin{array}{c}\text { Liga Guineense para Proteção } \\
\text { Ecológica (LIPE) }\end{array}$ & $233(0,05 \%-0$ assento $)$ \\
\hline
\end{tabular}

\begin{tabular}{|l|l|}
\hline \multicolumn{2}{|c|}{2009 (Primeiro Turno) } \\
\hline Presidencial ou Legislativa & Presidencial \\
\hline Quantidade de Assentos & 1 \\
\hline Quantidade de Eleitores Registrados & 593.765 \\
\hline Total de Votos & $356.340(60 \%)$ \\
\hline
\end{tabular}




\begin{tabular}{|c|l|}
\hline Votos Inválidos & 18.383 \\
\hline Votos Válidos & 371.025 \\
\hline Malam Bacai Sanhá (PAIGC) & $133.786(39,59 \%)$ \\
\hline Kumba Ialá (PRS) & $99.428(29,42 \%)$ \\
\hline Henrique Pereira Rosa & $81.751(24,19 \%)$ \\
\hline Mamadú Iaia Djaló (PND) & $10.495(3,1 \%)$ \\
\hline João Gomes Cardoso & $4.115(1,22 \%)$ \\
\hline Serifo Baldé (PDSSG-PJ) & $1.794(0,53 \%)$ \\
\hline Aregado Mantenque Té (PT) & $1.736(0,51 \%)$ \\
\hline Ibraima Djaló & $1.489(0,44 \%)$ \\
\hline Francisca "Zinha" Vaz Turpin (UPG) & $1.219(0,36 \%)$ \\
\hline Luís Nancassa & $1.195(0,35 \%)$ \\
\hline Paulo Mendonça & $949(0,28 \%)$ \\
\hline
\end{tabular}

\begin{tabular}{|l|l|}
\hline \multicolumn{2}{|c|}{2009 (Segundo Turno) } \\
\hline Presidencial ou Legislativa & Presidencial \\
\hline Quantidade de Assentos & 1 \\
\hline Quantidade de Eleitores Registrados & 593.765 \\
\hline Total de Votos & $362.736(61,1 \%)$ \\
\hline Votos Inválidos & 8504 \\
\hline Votos Válidos & 354.232 \\
\hline Malam Bacai Sanhá (PAIGC) & $224.259(63,31 \%)$ \\
\hline Kumba Ialá (PRS) & $129.973(36,69 \%)$ \\
\hline
\end{tabular}

\begin{tabular}{|l|l|}
\hline \multicolumn{2}{|l|}{$\mathbf{2 0 1 2}$} \\
\hline Presidencial ou Legislativa & Presidencial \\
\hline Quantidade de Assentos & 1 \\
\hline Quantidade de Eleitores Registrados & 593.765 \\
\hline Total de Votos & $326.399(55 \%)$ \\
\hline Votos Inválidos & 10.292 \\
\hline Votos Válidos & 316.107 \\
\hline Carlos Gomes Júnior (PAIGC) & $154.797(48,97 \%)$ \\
\hline
\end{tabular}




\begin{tabular}{|c|l|}
\hline Kumba Ialá (PRS) & $73.842(23,36 \%)$ \\
\hline Manuel Serifo Nhamadjo & $49.767(15,74 \%)$ \\
\hline Henrique Pereira Rosa & $17.070(5,40 \%)$ \\
\hline Baciro Djá & $10.298(3,26 \%)$ \\
\hline Vicente Fernandes (AD) & $4.396(1,39 \%)$ \\
\hline Aregado Mantenque Té (PT) & $3.300(1,04 \%)$ \\
\hline Serifo Baldé (PDSSG-PJ) & $1.463(0,46 \%)$ \\
\hline Luís Nancassa & $1.174(0,37 \%)$ \\
\hline
\end{tabular}

\begin{tabular}{|c|c|}
\hline \multicolumn{2}{|c|}{2014 (Primeiro Turno) } \\
\hline Presidencial ou Legislativa & Presidencial \\
\hline Quantidade de Assentos & 1 \\
\hline Quantidade de Eleitores Registrados & 775.508 \\
\hline Total de Votos & $692.440(89,29 \%)$ \\
\hline Votos Inválidos & 62.514 \\
\hline Votos Válidos & 629.926 \\
\hline José Mário Vaz (PAIGC) & $252.269(40,98 \%)$ \\
\hline Nuno Gomes Nabiam & $154.784(25,14 \%)$ \\
\hline Paulo Fernando Gomes & $60.783(9,87 \%)$ \\
\hline Abel Iamedi Incada (PRS) & $43.293(7,03 \%)$ \\
\hline Mamadú Iaia Djaló (PND) & $28.068(4,56 \%)$ \\
\hline Ibraima Sori Djaló (PRN) & $19.209(3,12 \%)$ \\
\hline António Afonso Té (PRID) & $18.398(2,99 \%)$ \\
\hline Hélder Jorge Vaz Gomes Lopes (RGB) & $8.516(1,38 \%)$ \\
\hline Domingo Quadé & $8.432(1,37 \%)$ \\
\hline Aregado Mantenque (PT) & $7.105(1,15 \%)$ \\
\hline Luís Nancassá & $6.815(1,11 \%)$ \\
\hline Jorge Malú & $5.946(0,97 \%)$ \\
\hline $\begin{array}{l}\text { Cirilo Augusto Rodrigues de Oliveira } \\
\text { (PS-GB) }\end{array}$ & $2.036(0,33 \%)$ \\
\hline
\end{tabular}




\begin{tabular}{|l|l|}
\hline \multicolumn{2}{|c|}{2014 (Segundo Turno) } \\
\hline Presidencial ou Legislativa & Presidencial \\
\hline Quantidade de Assentos & 1 \\
\hline Quantidade de Eleitores Registrados & 775.508 \\
\hline Total de Votos & $606.536(78,21 \%)$ \\
\hline Votos Inválidos e Brancos & 18.053 \\
\hline Votos Válidos & 588.483 \\
\hline José Mário Vaz (PAIGC) & $364.394(61,90 \%)$ \\
\hline Nuno Gomes Nabiam & $224.089(38,10 \%)$ \\
\hline
\end{tabular}

\begin{tabular}{|c|c|}
\hline \multicolumn{2}{|c|}{2014} \\
\hline Presidencial ou Legislativa & Legislativas \\
\hline Quantidade de Assentos & 102 \\
\hline Quantidade de Eleitores Registrados & 775.508 \\
\hline Total de Votos & $686.876(88,57 \%)$ \\
\hline Votos Inválidos e Brancos & 100.352 \\
\hline Votos Válidos & $586.524(85,39 \%)$ \\
\hline $\begin{array}{c}\text { Partido Africano para a Independência } \\
\text { da Guiné e Cabo Verde (PAIGC) }\end{array}$ & $281.408(47,98 \%-57$ assentos $)$ \\
\hline Partido da Renovação Social (PRS) & $180.432(30,76 \%-41$ assentos $)$ \\
\hline Partido Nova Democracia (PND) & $28.581(4,87 \%-1$ assento $)$ \\
\hline $\begin{array}{c}\text { Partido da Convergência Democrática } \\
\text { (PCD) }\end{array}$ & $19.757(3,37 \%-2$ assentos $)$ \\
\hline $\begin{array}{l}\text { Partido Republicano da Independência } \\
\text { para o Desenvolvimento (PRID) }\end{array}$ & $17.919(3,06 \%-0$ assento $)$ \\
\hline União Patriótica Guineense (UPG) & $10.919(1,86 \%-0$ assento $)$ \\
\hline União para a Mudança (UM) & $10.803(1,84 \%-1$ assento $)$ \\
\hline $\begin{array}{c}\text { Resistência Guiné-Bissau/ Movimento } \\
\text { Bafatá (RGB) }\end{array}$ & $9.502(1,62 \%-0$ assento $)$ \\
\hline $\begin{array}{c}\text { Partido da Reconciliação Nacional } \\
\text { (PRN) }\end{array}$ & $7.903(1,35 \%-0$ assento $)$ \\
\hline Manifesto do Povo (MP) & $4.101(0,70 \%-0$ assento $)$ \\
\hline $\begin{array}{c}\text { Partido Unido Social Democrático } \\
\text { (PUSD) }\end{array}$ & $4.048(0,69 \%-0$ assento $)$ \\
\hline Partido dos Trabalhadores (PT) & $3.659(0,62 \%-0$ assento $)$ \\
\hline $\begin{array}{l}\text { Partido Social da Guiné-Bissau (PS- } \\
\text { GB) }\end{array}$ & $3.480(0,59 \%$ - 0 assento $)$ \\
\hline
\end{tabular}




\begin{tabular}{|l|l|}
\hline Partido Social Democrático (PSD) & $2.302(0,39 \%-0$ assento $)$ \\
\hline Frente Democrática Social (FDS) & $1.710(0,29 \%-0$ assento $)$ \\
\hline
\end{tabular}

Fonte: UNIÃO EUROPEIA. Guiné Bissau Relatório Final Eleições Presidenciais e Legislativas, abr. 2014. Disponível em: <http://www.eods.eu/library/eueomguineabissau-final-report_pt.pdf $>$. Acesso em: 2 fev. 2016. 


\section{ANEXO F - RECEBIMENTO DE AJUDA OFICIAL DOS PALOP DE 1967 A 2015}

\section{Gráfico - Ajuda oficial para o desenvolvimento e ajuda oficial recebida (em US\$) por Cabo Verde de 1967 a 2015 (WORLD BANK, 2017)}

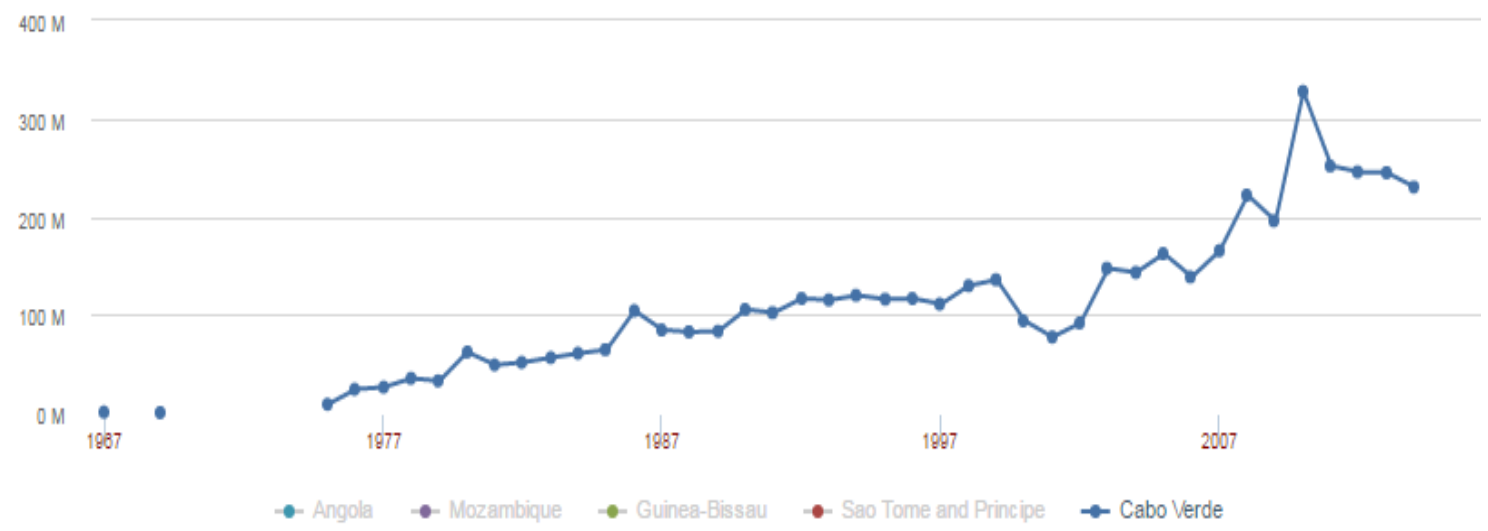

Fonte: Net official development assistance and official aid received (current US\$). World Development Indicators. Disponível em http://databank.worldbank.org/data/reports.aspx?source=world-developmentindicators\#advancedDownloadOptions Acesso em 05 de janeiro de 2017.

\section{Gráfico - Ajuda oficial para o desenvolvimento e ajuda oficial recebida (em} US\$) por São Tomé e Príncipe de 1967 a 2015 (WORLD BANK, 2017)

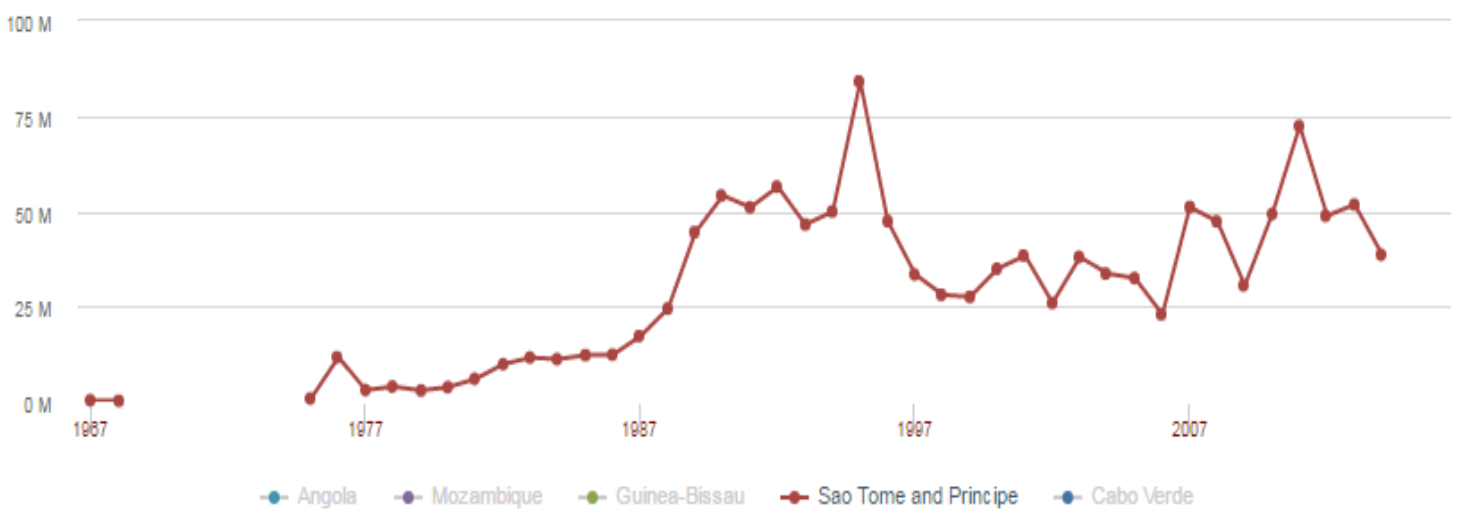

Fonte: Net official development assistance and official aid received (current US\$). World Development Indicators. Disponível em http://databank.worldbank.org/data/reports.aspx?source=world-developmentindicators\#advancedDownloadOptions Acesso em 05 de janeiro de 2017. 
Gráfico - Ajuda oficial para o desenvolvimento e ajuda oficial recebida (em US\$) por Moçambique de 1967 a 2015 (WORLD BANK, 2017)

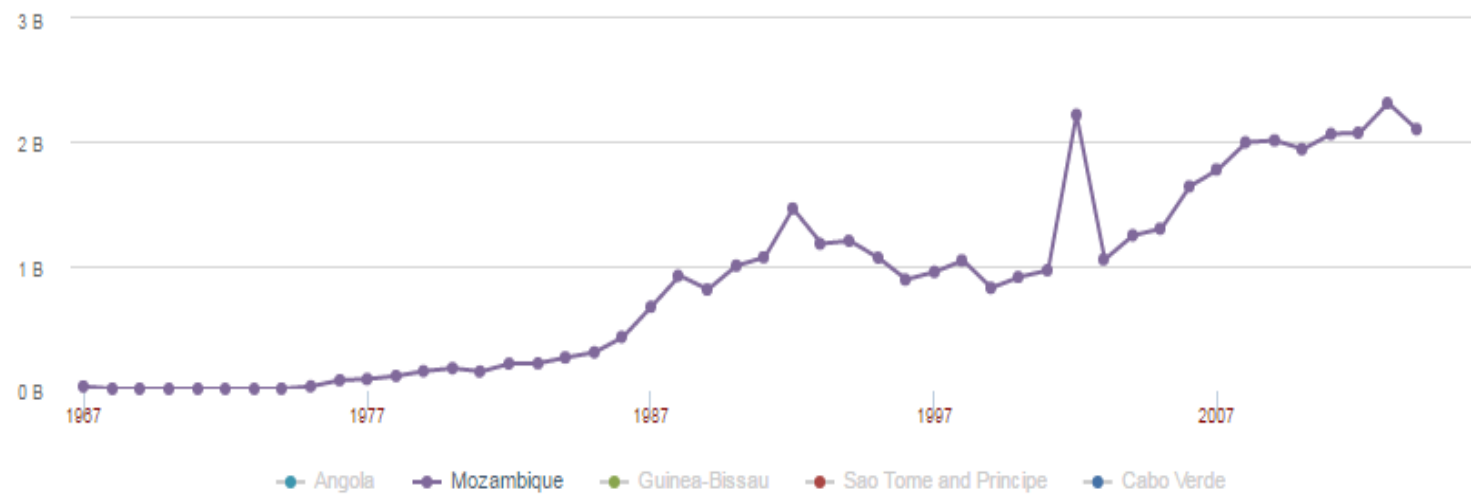

Fonte: Net official development assistance and official aid received (current US\$). World Development Indicators. Disponível em http://databank.worldbank.org/data/reports.aspx?source=world-developmentindicators\#advancedDownloadOptions Acesso em 05 de janeiro de 2017.

\section{Gráfico - Ajuda oficial para o desenvolvimento e ajuda oficial recebida (em US\$) por Guiné-Bissau de 1967 a 2015 (WORLD BANK, 2017)}

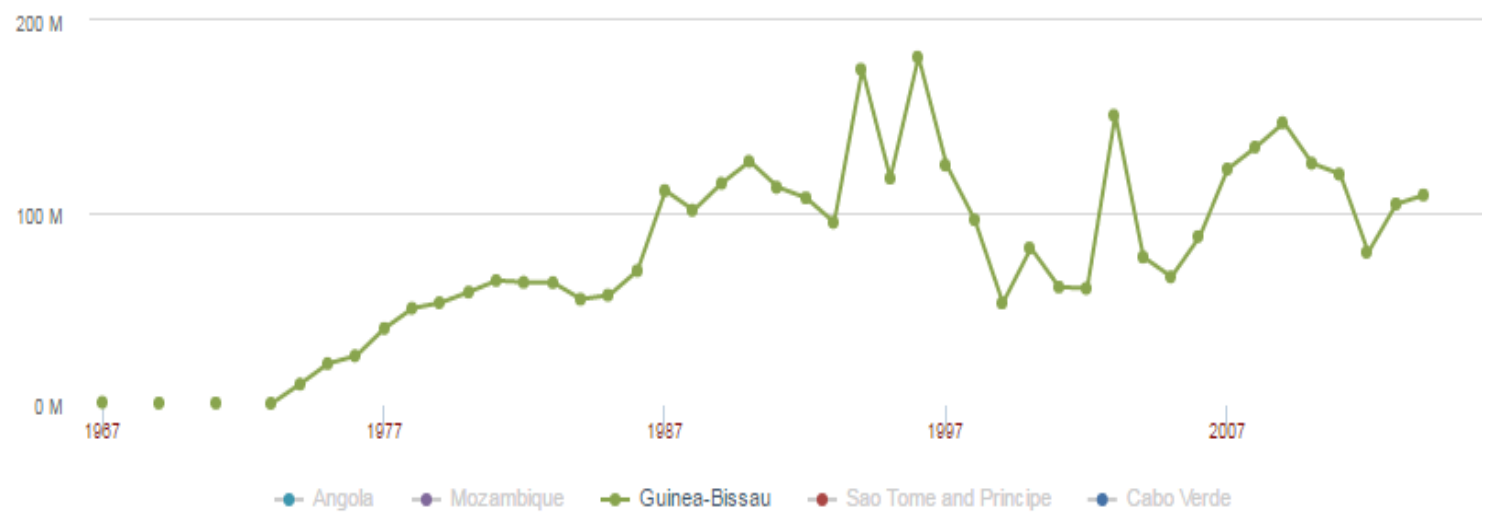

Fonte: Net official development assistance and official aid received (current US\$). World Development Indicators. Disponível em http://databank.worldbank.org/data/reports.aspx?source=world-developmentindicators\#advancedDownloadOptions Acesso em 05 de janeiro de 2017. 
Gráfico - Ajuda oficial para o desenvolvimento e ajuda oficial recebida (em US\$) por Angola de 1967 a 2015 (WORLD BANK, 2017)

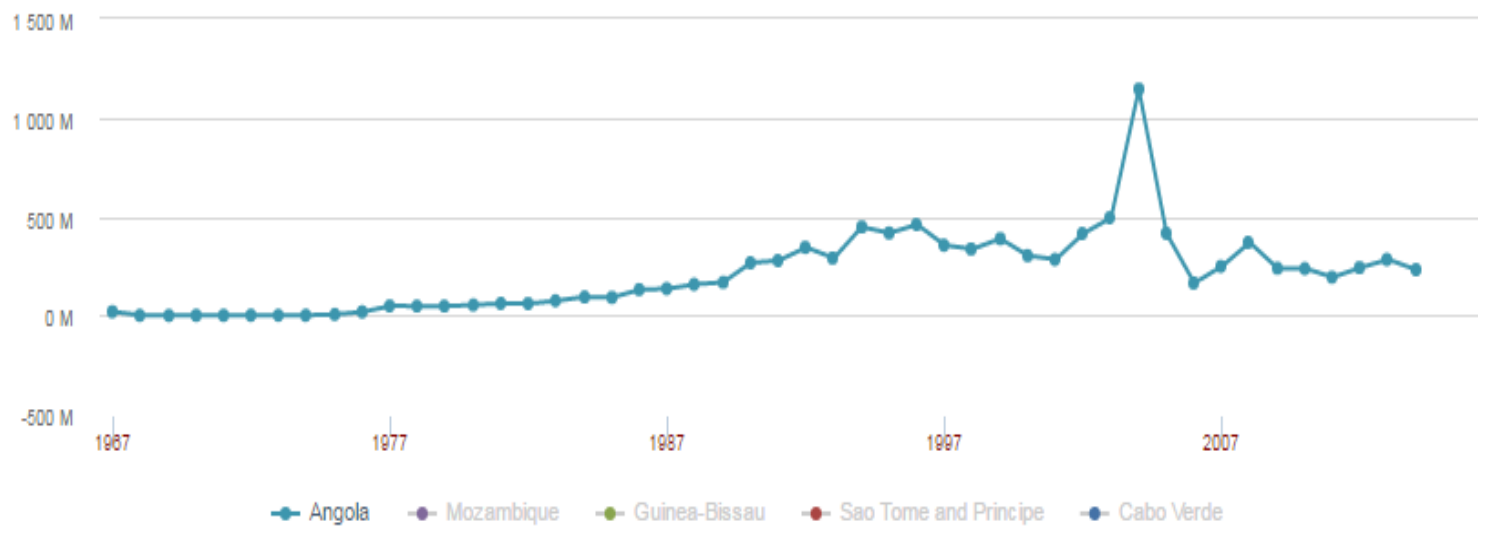

Fonte: Net official development assistance and official aid received (current US\$). World Development Indicators. Disponível em http://databank.worldbank.org/data/reports.aspx?source=world-developmentindicators\#advancedDownloadOptions Acesso em 05 de janeiro de 2017. 